Electronic Supplementary Information for:

\title{
Caged Cyclopropenes with Improved Tetrazine Ligation Kinetics
}

Pratik Kumar, ${ }^{\dagger}$ Omar Zainul, ${ }^{\dagger}$ Frank M. Camarda, ${ }^{\dagger}$ Ting Jiang, ${ }^{\dagger}$ John A. Mannone,${ }^{\dagger}$ Wei Huang, ${ }^{\dagger}$ and Scott T. Laughlin $t, \neq, *$

tDepartment of Chemistry, Stony Brook University, Stony Brook, NY, 11790, United States

*Corresponding author e-mail: scott.laughlin@stonybrook.edu 
General materials and methods....................................................................................................................

Scheme S1: Synthetic procedures for S1-3................................................................................................. 6

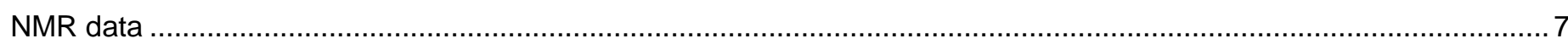

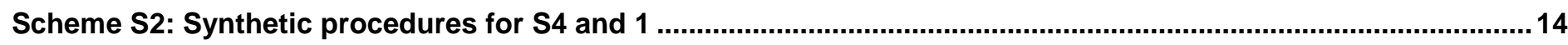

Table A: Optimization conditions for conversion of protection of ketone in 3-oxopyrrolidine derivative S3 via acid

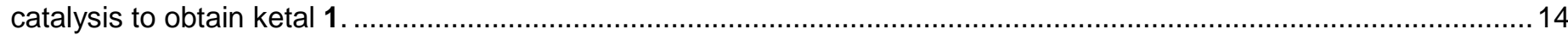

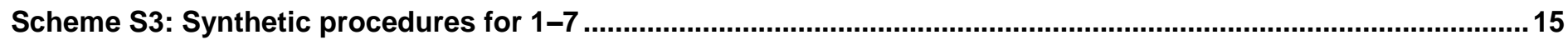

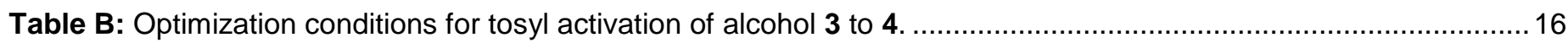

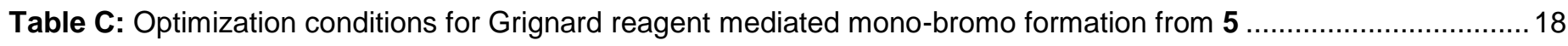

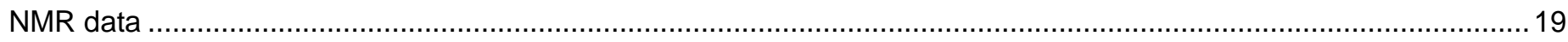

Scheme S4: Synthetic procedures for 8, 9a-b, 10a-b and 11a-b...................................................................44

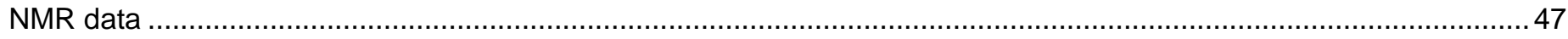

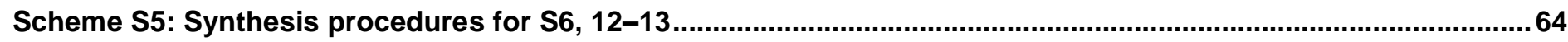

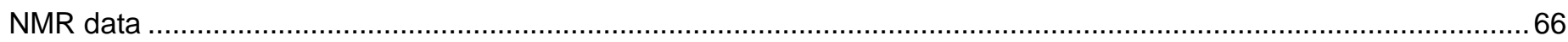

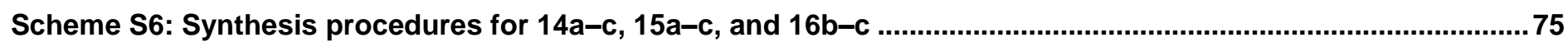

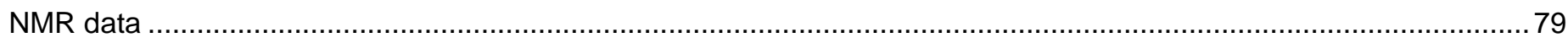

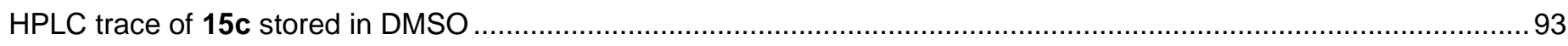

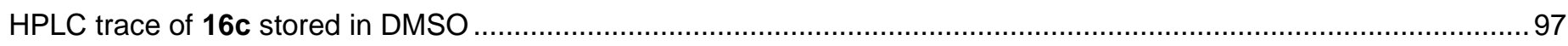

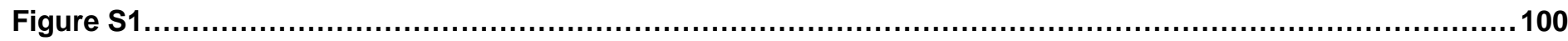

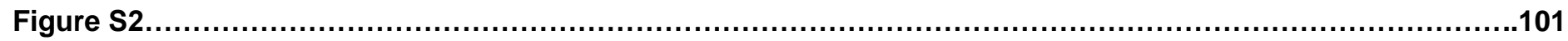

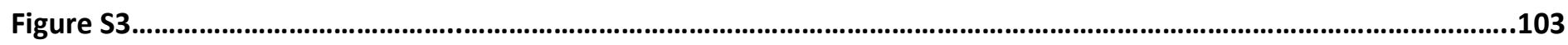

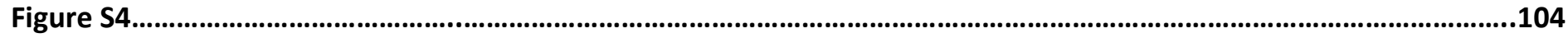

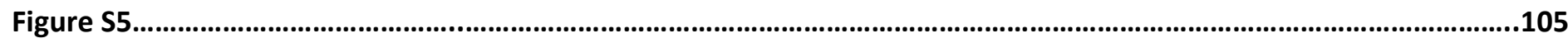

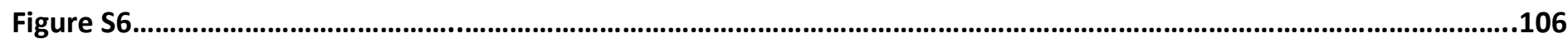

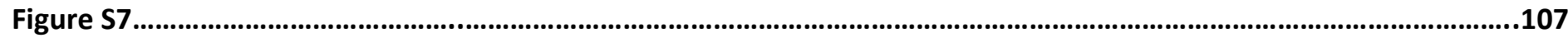

Scheme S7: Computational calculations......................................................................................................... 100

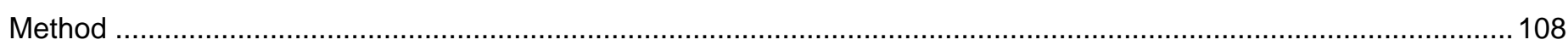

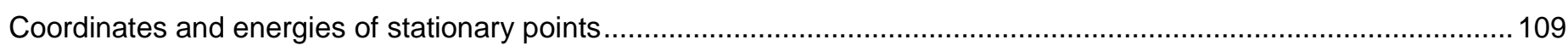

References ................................................................................................................................................ 114 


\section{List of abbreviations}

\begin{tabular}{ll} 
CDI & 1,1 '-Carbonyldiimidazole \\
COSY & Correlation spectroscopy \\
CTAB & Cetyltrimethylammonium bromide \\
DCM & Dichloromethane \\
DEPT & Distortionless enhancement by polarization transfer \\
DMF & $N, N$-Dimethylformamide \\
eq & Equivalents \\
ESI & Electrospray ionization \\
EtOAc & Ethyl acetate \\
EtOH & Ethanol \\
HPLC & High pressure liquid chromatography \\
HRMS & High resolution mass spectrometry \\
LAH & Lithium aluminum hydride \\
LiHMDS & Lithium bis(trimethylsilyl)amide \\
MHz & Mega Hertz \\
MeCN & Acetonitrile \\
MeOH & Methanol \\
MS & Mass spectrometry \\
NMR & Nuclear magnetic resonance \\
Rf & Retention factor \\
Rt & Retention time \\
THF & Tetrahydrofuran \\
TLC & Thin layer chromatography \\
UV & Ultraviolet \\
\hline H &
\end{tabular}


General materials and methods. All chemical reagents were of analytical grade, obtained from commercial suppliers, and used without further purification unless otherwise specified. Rhodium (II) acetate $\left(\mathrm{Rh}_{2} \mathrm{OAc} 4\right)$ was gently heated under vacuum until it became a free-flowing powder (typically 15-20 s) before using it for reactions. Reactions were monitored by thin layer chromatography (TLC) on pre-coated glass TLC plates (Analtech UNIPLATE ${ }^{\text {TM }}$ silica gel HLF w/ organic binder, $250 \mu \mathrm{m}$ thickness, with UV254 indicator) or by LC/MS (Agilent LC-MSD, direct-injection mode, 1-10 $\mu$ L, ESI). TLC plates were visualized by UV illumination or developed with either potassium permanganate stain $\left(\mathrm{KMnO}_{4}\right.$ stain: $1.5 \mathrm{~g} \mathrm{KMnO}_{4}, 10$ $\mathrm{g} \mathrm{K}_{2} \mathrm{CO}_{3}$ and $1.25 \mathrm{~mL}$ of $10 \% \mathrm{NaOH}$ dissolved in $200 \mathrm{~mL} \mathrm{H} \mathrm{H}_{2}$ ), ceric ammonium molybdate stain (CAM stain: $12 \mathrm{~g}$ $\left(\mathrm{NH}_{4}\right)_{6} \mathrm{Mo}_{7} \mathrm{O}_{24} \cdot 4 \mathrm{H}_{2} \mathrm{O}, 0.5 \mathrm{~g} \mathrm{Ce}\left(\mathrm{NH}_{4}\right)_{2}\left(\mathrm{NO}_{3}\right)_{6}$ and $15 \mathrm{~mL}$ of concentrated $\mathrm{H}_{2} \mathrm{SO}_{4}$ dissolved in $\left.235 \mathrm{~mL} \mathrm{H}_{2} \mathrm{O}\right)$, or ninhydrin stain ( $1.5 \mathrm{~g}$ ninhydrin dissolved in $100 \mathrm{~mL}$ of 1 -butanol and $3 \mathrm{~mL}$ of conc. AcOH). Flash chromatography was carried out using Sorbtech, $60 \AA$, 40-63 $\mu \mathrm{m}$ or Millipore $60 \AA$, 35-70 $\mu \mathrm{m}$ silica gel according to the procedure described by Still ${ }^{1}$. HPLC was performed using a Shimadzu HPLC (FCV-200AL) equipped with an Agilent reversed phase Zorbax Sb-Aq C18 column (4.6 $\times 250 \mathrm{~mm}$ or $21.2 \times 250 \mathrm{~mm})$ fitted with an Agilent stand-alone prep guard column. NMR spectra $\left({ }^{1} \mathrm{H}\right.$ and $\left.{ }^{13} \mathrm{C}\right)$ were obtained using a 300, 400,500, or $700 \mathrm{MHz}$ Bruker spectrometer and analyzed using Mestrenova 9.0. ${ }^{1} \mathrm{H}$ and ${ }^{13} \mathrm{C}$ chemical shifts ( $\delta$ ) were referenced to residual solvent peaks. Following residual solvent peaks were chosen: (for $\left.{ }^{1} \mathrm{H} \mathrm{NMR}\right) \mathrm{CDCl}_{3}, 7.2600 \mathrm{ppm}$; $\mathrm{CD}_{3} \mathrm{OD}$, 3.3100 ppm; $\left(\mathrm{CD}_{3}\right)_{2} \mathrm{SO}, 2.5000$ ppm (for $\left.{ }^{13} \mathrm{C} \mathrm{NMR}\right) \mathrm{CDCl}_{3}, 77.1600$ ppm; $\mathrm{CD}_{3} \mathrm{OD}, 49.0000$ ppm; $\left(\mathrm{CD}_{3}\right)_{2} \mathrm{SO}_{3}, 39.5200$ ppm; $\mathrm{D}_{2} \mathrm{O}, 4.7900$ ppm. Further, following abbreviations were used to define ${ }^{1} \mathrm{H}$ NMR peaks: s, singlet; $d$, doublet; $t$, triplet; q, quartet; $m$, multiplet. Low-resolution electrospray ionization (ESI) and High-resolution electrospray ionization (ESI) mass spectra were obtained at the Stony Brook University Institute for Chemical Biology and Drug Discovery (ICB\&DD) Mass Spectrometry Facility with an Agilent LC/MSD and LC-UV-TOF spectrometer respectively. Reaction kinetics were determined by measuring absorbance over time in a 96-well plate format with a BioTek Synergy2 microplate reader. All the HPLC traces are obtained by UV-detection at $220 \mathrm{~nm}$. Each HPLC peak was confirmed by either low-resolution mass spectrometry (MS) or high-resolution mass spectrometry (HRMS).

HPLC-based analysis of stability of cyclopropene 11 at $37^{\circ} \mathbf{C}:$ A solution of $11(2.5 \mathrm{mM})$ in $400 \mu \mathrm{L}$ of $1: 1 \mathrm{MeCN} / \mathrm{PBS}$ $(\mathrm{pH}=7.4)$ was incubated in the dark at $37^{\circ} \mathrm{C}$. At each designated time point $(0 \mathrm{~h}$ and $24 \mathrm{~h})$, a $25 \mu \mathrm{L}$ aliquot was withdrawn from the reaction mixture, diluted to $100 \mu \mathrm{L}$ using $30 \% \mathrm{MeCN} / \mathrm{H}_{2} \mathrm{O}$, and subjected to HPLC $(30-100 \% \mathrm{MeCN}+0.1 \%$ TFA over $25 \mathrm{mins}$, then $100 \% \mathrm{MeCN}$, flow rate $=1 \mathrm{~mL} / \mathrm{min}$ ). No decomposition products were observed for at least $24 \mathrm{~h}$. The HPLC peaks were confirmed to be the expected, unreacted 11 by MS analyses.

HPLC-analyses of no reactivity between reduced L-glutathione and cyclopropene 11 for $24 \mathrm{~h}$ at rt and $37^{\circ} \mathrm{C}$ : $\mathrm{A}$ reaction mixture consisting of $11(2.5 \mathrm{mM})$ and L-glutathione $(10 \mathrm{mM})$ in $200 \mu \mathrm{L}$ of $1: 1 \mathrm{MeCN} / \mathrm{PBS}(\mathrm{pH}=7.4)$ was incubated in the dark at either rt or $37^{\circ} \mathrm{C}$. At each designated time point, a $25 \mu \mathrm{L}$ aliquot was withdrawn from the reaction mixture, diluted to $100 \mu \mathrm{L}$ using $30 \% \mathrm{MeCN} / \mathrm{H}_{2} \mathrm{O}$, and subjected to HPLC (30-100\% MeCN $+0.1 \%$ TFA over 25 mins, then $100 \%$ $\mathrm{MeCN}$, flow rate $=1 \mathrm{~mL} / \mathrm{min}$ ). No decomposition or ligated products were observed for at least $24 \mathrm{~h}$ for each temperature condition. Each HPLC peak was confirmed to be the expected, unreacted reagent by MS analyses.

HPLC-analyses of no reactivity between BnSH and cyclopropene 11 for $\mathbf{2 4} \mathbf{~ h}$ : A reaction mixture consisting of 11 (2.5 $\mathrm{mM})$ and $\mathrm{BnSH}(10 \mathrm{mM})$ in $200 \mu \mathrm{L}$ of $1: 1 \mathrm{MeCN} / \mathrm{PBS}(\mathrm{pH}=7.4)$ was incubated in the dark at rt . At each designated time point (0h and $24 \mathrm{~h}$ ), a $25 \mu \mathrm{L}$ aliquot was withdrawn from the reaction mixture, diluted to $100 \mu \mathrm{L}$ using $30 \% \mathrm{MeCN} / \mathrm{H}_{2} \mathrm{O}$, and subjected to HPLC $(30-100 \% \mathrm{MeCN}+0.1 \%$ TFA over 25 mins, then $100 \% \mathrm{MeCN}$, flow rate $=1 \mathrm{~mL} / \mathrm{min})$. No decomposition 
or ligated products were observed for at least $24 \mathrm{~h}$. Each HPLC peak was confirmed to be the expected, unreacted reagent by MS analyses.

HPLC-analyses of no reactivity between tetrazine 17 and cyclopropene 11 for 2 months in $1: 1 \mathrm{H}_{2} \mathrm{O} / \mathrm{MeCN}$ : $\mathrm{A}$ reaction mixture consisting of $11(1 \mathrm{mM})$ and $17(3 \mathrm{mM})$ in $500 \mu \mathrm{L}$ of $1: 1 \mathrm{MeCN} / \mathrm{H}_{2} \mathrm{O}$ was incubated in the dark at rt. At each designated time point ( $0 \mathrm{~h}, 1$ week, 1 month, and 2 months), a $50 \mu \mathrm{L}$ aliquot was withdrawn from the reaction mixture, diluted to $110 \mu \mathrm{L}$ using $30 \% \mathrm{MeCN} / \mathrm{H}_{2} \mathrm{O}$, and subjected to reversed phase HPLC $(30-100 \% \mathrm{MeCN}+0.1 \%$ TFA over 25 mins, then $100 \% \mathrm{MeCN}$, flow rate $=1 \mathrm{~mL} / \mathrm{min}$ ). No significant decomposition products or ligated product were observed. Each HPLC peak was confirmed to be the expected, unreacted reagent by MS analyses.

HPLC-analyses of reactivity between tetrazine 17 and cyclopropene 11 for 1 month in 1:1 PBS/MeCN: A reaction mixture consisting of $11(1 \mathrm{mM})$ and $17(3 \mathrm{mM})$ in $500 \mu \mathrm{L}$ of $1: 1 \mathrm{MeCN} / \mathrm{PBS}(\mathrm{pH}=7.4)$ was incubated in the dark at rt. At each designated time point ( 0 h, 5 h, 1 day, 2 days, 4 days, 1 week, 2 weeks, and 4 weeks), a $50 \mu \mathrm{L}$ aliquot was withdrawn from the reaction mixture, diluted to $110 \mu \mathrm{L}$ using $30 \% \mathrm{MeCN} / \mathrm{H}_{2} \mathrm{O}$, and subjected to reversed phase $\mathrm{HPLC}(30-100 \%$ $\mathrm{MeCN}+0.1 \%$ TFA over 25 mins, then $100 \% \mathrm{MeCN}$, flow rate $=1 \mathrm{~mL} / \mathrm{min})$. The identity of each HPLC peak was confirmed by MS analysis. We found slow formation of ligated product in buffer and confirmed it by HRMS. ESI: Calcd for $\mathrm{C}_{30} \mathrm{H}_{32} \mathrm{~N}_{5} \mathrm{O}_{8}$ $[\mathrm{M}+\mathrm{H}]+$ : 590.2245 , found: 590.2246 .

$2^{\text {nd }}$ order rate constant determination for reaction between cyclopropene 10a and tetrazine 17: Reaction mixtures consisting of at least 10-fold excess cyclopropene 10a (40,60, and $90 \mathrm{mM}$ ) and $17(4 \mathrm{mM})$ in 1:1 MeOH/PBS (total volume $=200 \mu \mathrm{L}, \mathrm{pH}$ 7.4) were prepared in separate wells of a 96-well plate at rt. The reaction progress was monitored by recording the disappearance of the characteristic s-tetrazine absorbance $\left(A_{c p+T z}\right)$ at $520 \mathrm{~nm}$ every 45 seconds. Separately, absorbance $\left(A_{c p}\right)$ of solutions consisting of cyclopropene 10a $(40,60,90 \mathrm{mM}$ ) in 1:1 MeOH/PBS (total volume $=200 \mu \mathrm{L}$, $\mathrm{pH}$ 7.4) without any tetrazine was also recorded. These cyclopropene-absorbances only were subtracted from the total absorbance of tetrazine-ligation kinetics to negate the effect of cyclopropene absorbance at $520 \mathrm{~nm}$. Because the expected concentration of cyclopropene at the end of the reaction $(36,56,86 \mathrm{mM})$ will be similar to the starting concentration, the slight change in cyclopropene absorbance over the course of the experiment can be overlooked. The pseudo $1^{\text {st }}$ order rates were then obtained by plotting the normalized absorbance $\left(A / A_{o}=A_{c p+T z}-A_{c p}\right)$ with respect to the initial absorbance of tetrazine only $\left(A_{\circ}\right)$ against reaction time (using the pseudo $1^{\text {st }}$ order rate equation $A=A_{0}$.exp (-k.[10a].t) where $A=$ absorbance at time $t, A_{o}=$ initial absorbance of tetrazine only, $k \cdot[\mathbf{1 0 a}]=$ pseudo $1^{\text {st }}$ order rate constant, and $t=$ time). The $2^{\text {nd }}$ order rate constants were obtained by plotting the pseudo $1^{\text {st }}$ order rates against the concentration of $10 \mathrm{a}$. 


\section{Scheme S1: Synthetic procedures for S1-3}

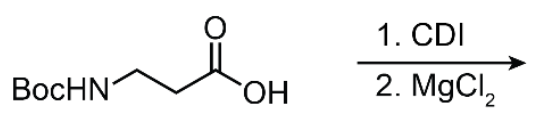

Boc- $\beta$-alanine

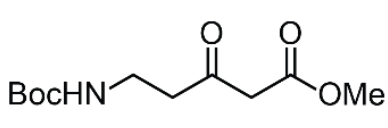

S1 used without further purification

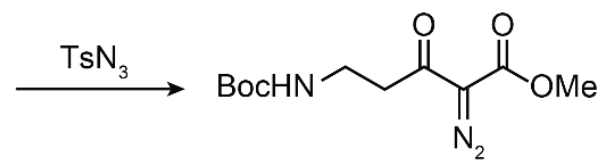

S2, $90-95 \%$

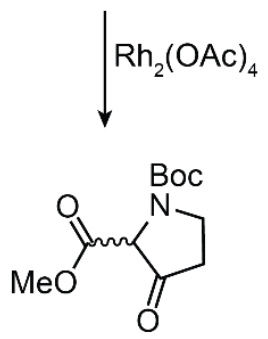

S3, $91.2 \%$

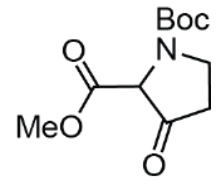

S3

S3 was synthesized in three steps starting from Boc- $\beta$-alanine as described in our previously published protocol ${ }^{2}$ which was adapted from Sorensen and co-workers' method ${ }^{3}$. Briefly, to a solution of Boc- $\beta$-alanine (32.0 g, $169.12 \mathrm{mmol}, 1.0 \mathrm{eq})$ in THF ( $200 \mathrm{~mL})$ at rt was added CDI (32.91 g, 202.95 $\mathrm{mmol}, 1.2 \mathrm{eq})$ and the reaction was stirred overnight. To this activated amide $\left(\mathrm{R}_{\mathrm{f}}=0.25,50 \%\right.$ EtOAc/hexanes, visualized w/ UV) was added overnight stirred suspension of anhydrous $\mathrm{MgCl}_{2}$ (22.55 g, $236.77 \mathrm{mmol}, 1.4 \mathrm{eq}$ ), potassium 3-methoxy-3-oxopropanoate (36.98 g, $236.77 \mathrm{mmol}, 1.4$ eq), and $\mathrm{Et}_{3} \mathrm{~N}(36.0 \mathrm{~mL}, 253.69 \mathrm{mmol}, 1.5 \mathrm{eq})$ in THF $(250 \mathrm{~mL})$. The suspension was stirred at rt for $16 \mathrm{~h}$, quenched with water, and concentrated in vacuo to remove THF. The reaction mixture was then diluted with DCM and conc. $\mathrm{HCl}(\mathrm{pH}$ of water layer 1-2). The DCM layer was collected and the aqueous layer was further extracted with DCM. The combined organic layers were washed with brine, dried over anhydrous $\mathrm{Na}_{2} \mathrm{SO}_{4}$, and concentrated in vacuo to obtain a pale-yellow oil $\mathrm{S} 1$ that was used without further purification $(44.0 \mathrm{~g}) . \mathrm{R}_{\mathrm{f}}=0.31$ (30\% EtOAc/hexanes, visualized $\left.\mathrm{w} / \mathrm{UV}\right)$. To a solution of crude $\beta$-ketoester $\mathbf{S 1}(26.2 \mathrm{~g}, 106.8 \mathrm{mmol}, 1 \mathrm{eq})$ in $\mathrm{MeCN}(200 \mathrm{~mL})$ was added previously synthesized tosyl azide $(21.42 \mathrm{~g}$, $108.9 \mathrm{mmol}, 1.0 \mathrm{eq})$. Et ${ }_{3} \mathrm{~N}(44.4 \mathrm{~mL}, 320.4 \mathrm{mmol}, 3 \mathrm{eq})$ was added dropwise and the mixture was stirred at $\mathrm{rt}$ for $16 \mathrm{~h}$. The reaction mixture was concentrated in vacuo and diluted with ether and $\mathrm{KOH}(10 \% \mathrm{w} / \mathrm{v}, \mathrm{aq})$. The organic layer was further washed with $\mathrm{KOH}(3 \mathrm{x})$, brine, dried over anhydrous $\mathrm{Na}_{2} \mathrm{SO}_{4}$, concentrated in vacuo, and purified by flash chromatography (160 g silica, $10-30 \%$ ethyl acetate/hexanes $(\mathrm{v} / \mathrm{v})$ ) to obtain $\mathbf{S} 2$ as a yellow oil ( $27.0 \mathrm{~g}, 95.2 \%$ over two steps). $R_{f}=0.43$ (30\% EtOAc/hexanes, visualized w/ UV). To a solution of $\mathbf{S} 2(25.5 \mathrm{~g}, 94.06 \mathrm{mmol}, 1 \mathrm{eq})$ in dry toluene $(200 \mathrm{~mL})$ was added $\mathrm{Rh}_{2} \mathrm{OAc}_{4}\left(208 \mathrm{mg}, 0.47 \mathrm{mmol}, 0.005 \mathrm{eq}\right.$ ) and the mixture was stirred at $90{ }^{\circ} \mathrm{C}$ for $1.5 \mathrm{~h}$. The reaction mixture was concentrated in vacuo and passed through silica gel $(60 \mathrm{~g})$ using ether to obtain S3 as an oil that solidified upon freezing (20.85 g, 91.2\%). $\mathrm{R}_{\mathrm{f}}=0.27$ (30\% EtOAc/hexanes, visualized w/ UV). ${ }^{1} \mathrm{H}$ NMR (33:67 \% mixture of diastereomers, $700 \mathrm{MHz}$, $\left.\mathrm{CDCl}_{3}\right): \delta=4.14(\mathrm{~m}, 1 \mathrm{H}), 3.55-3.48(\mathrm{~m}, 1 \mathrm{H}), 3.45-3.39(\mathrm{~m}, 4 \mathrm{H}), 2.43-2.36(\mathrm{~m}, 1 \mathrm{H}), 2.35-2.31(\mathrm{~m}, 1 \mathrm{H}), 1.14-1.06(2 \times \mathrm{s}$, $9 H$ ). ${ }^{13} \mathrm{C}$ NMR (diastereomers, $175 \mathrm{MHz}, \mathrm{CDCl}_{3}$ ): $\delta=204.04,203.51,166.31,166.03,153.42,153.07,80.04,65.05,64.65$, 52.16, 52.12, 41.74, 41.07, 36.40, 35.70, 27.57, 27.44. ${ }^{13} \mathrm{C}$ DEPT-135 NMR (diastereomers, $\left.176 \mathrm{MHz}, \mathrm{CDCl}_{3}\right): \delta=(\mathrm{up})$ 65.33, 64.93, 52.44, 52.39, 27.84, 27.71, (down) 42.02, 52.39, 36.68, 35.98. MS (ESI): Calcd for $\mathrm{C}_{11} \mathrm{H}_{17} \mathrm{NO}_{5}[\mathrm{M}]^{+}: 243.1$, found: $144.1[\mathrm{M}-\mathrm{Boc}+2 \mathrm{H}]^{+}, 188.1\left[\mathrm{M}-\mathrm{C}\left(\mathrm{CH}_{3}\right)_{3}+2 \mathrm{H}\right]^{+}, 244.1[\mathrm{MH}]^{+}, 487.2[2 \mathrm{M}+\mathrm{H}]^{+}$. 
${ }^{1} \mathrm{H}$ NMR $(500 \mathrm{MHz})$

$\frac{m}{0}$
0
8
0
0
0

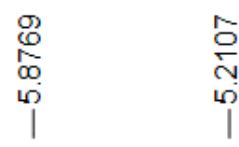

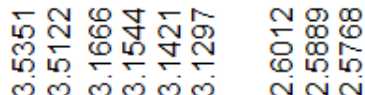

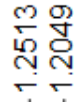
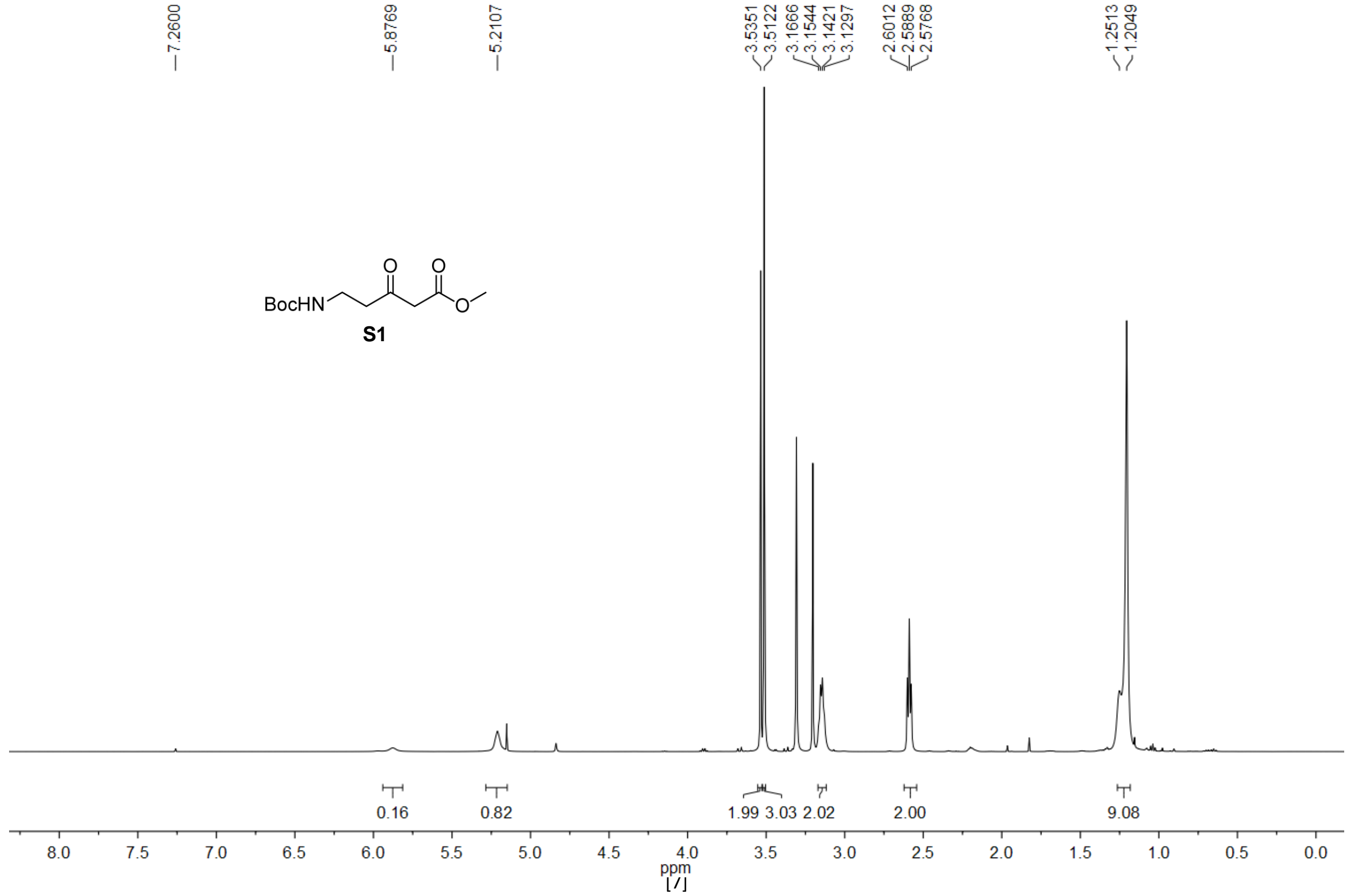
${ }^{13} \mathrm{C}$ NMR $(126 \mathrm{MHz})$

\begin{tabular}{|c|c|}
\hline 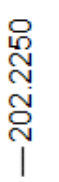 & 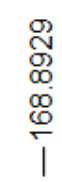 \\
\hline
\end{tabular}
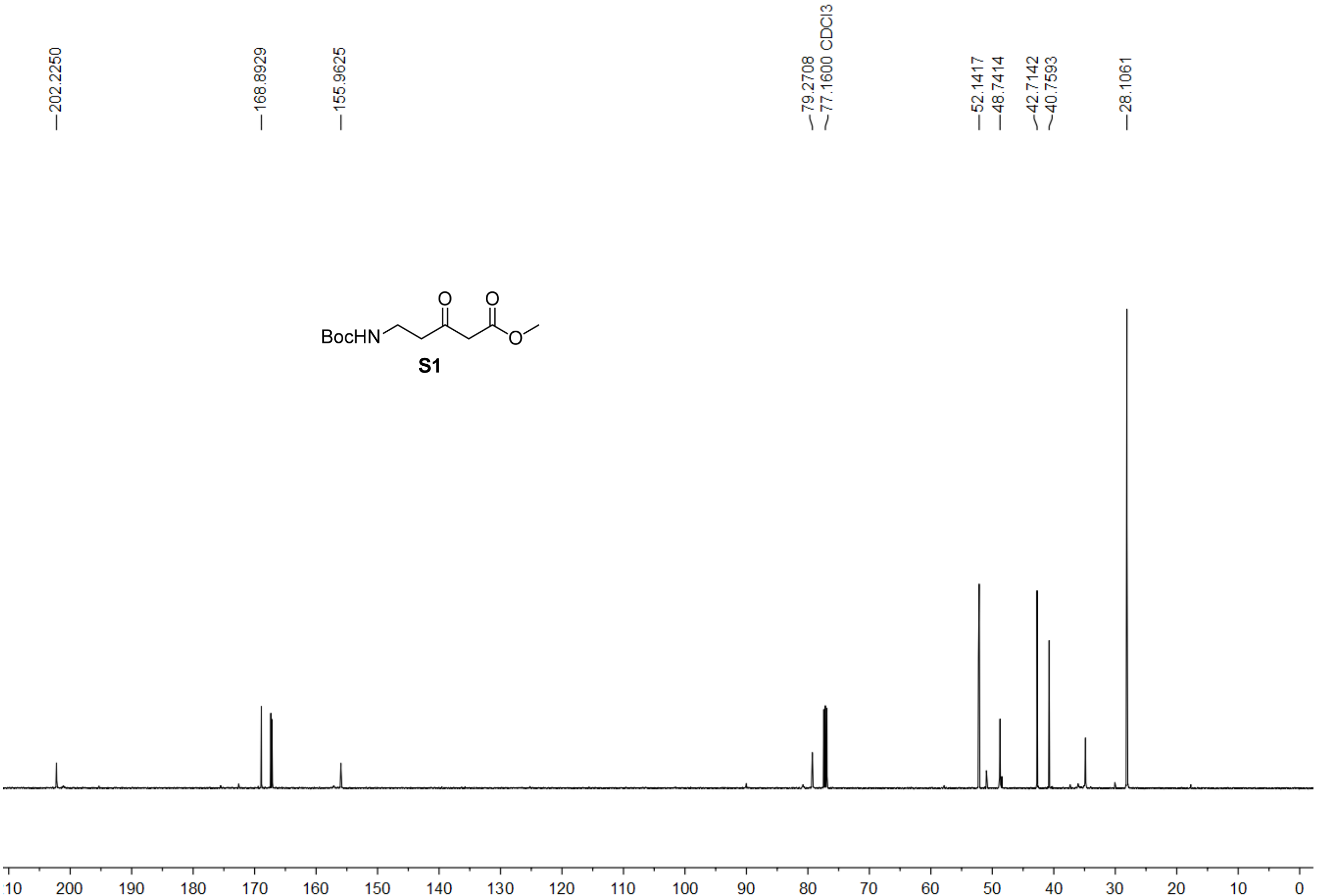

$10 \quad 200$

190 
${ }^{1} \mathrm{H}$ NMR $(500 \mathrm{MHz})$

$\frac{0}{0}$
0
0
0
0

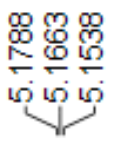

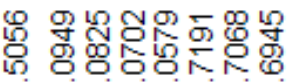

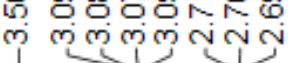

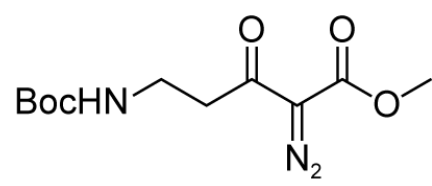

S2

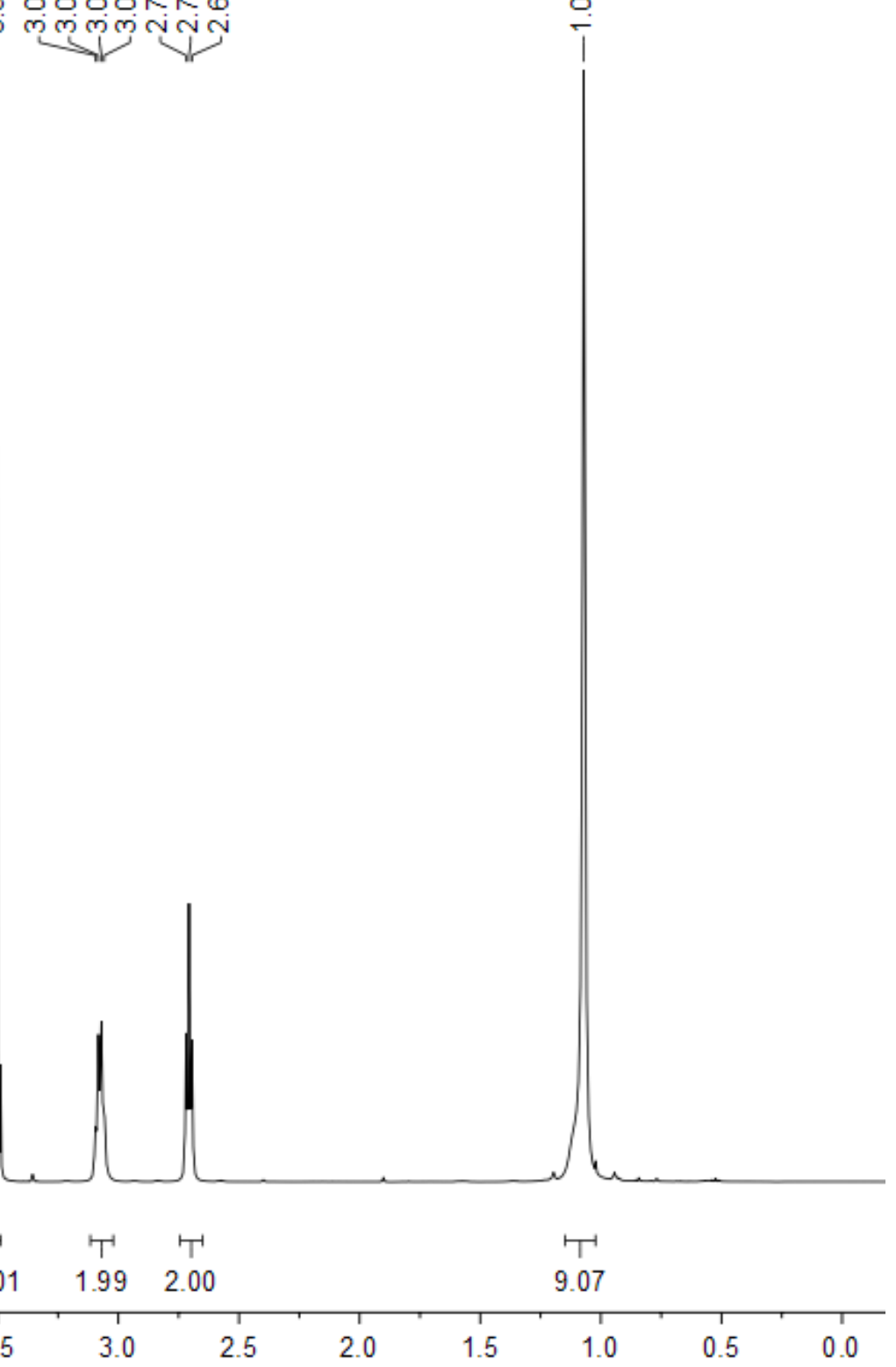

[9] 
${ }^{13} \mathrm{C}$ NMR (126 MHz)

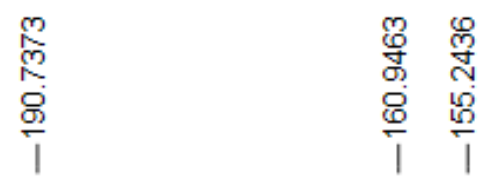

응

늉융응

要零

(i)

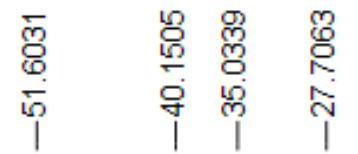

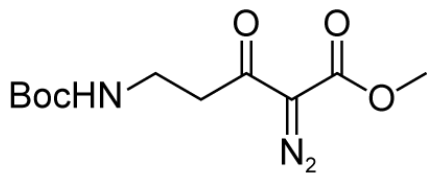

S2

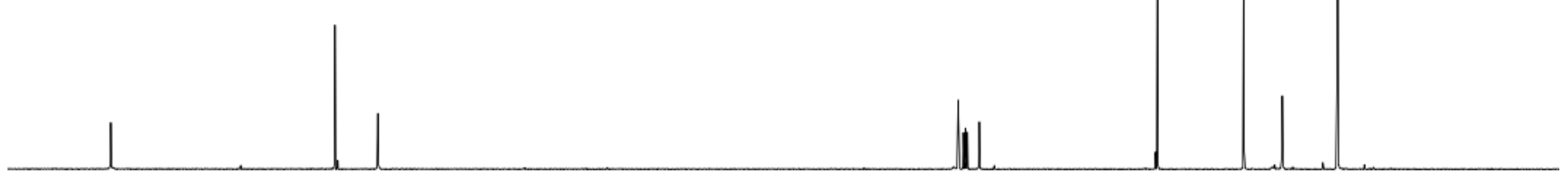

$$
200
$$




\section{${ }^{1} \mathrm{H}$ NMR $(700 \mathrm{MHz})$}

$\frac{1}{8}$
0
0
8
0
$\stackrel{0}{1}$
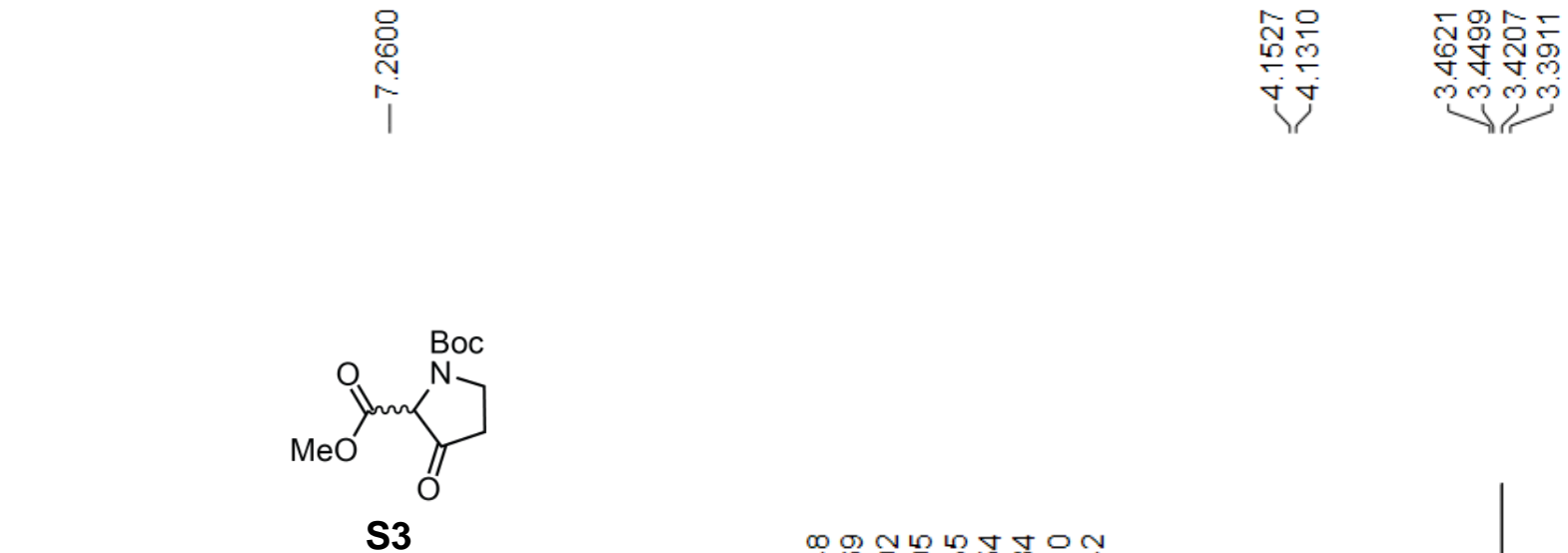

S3

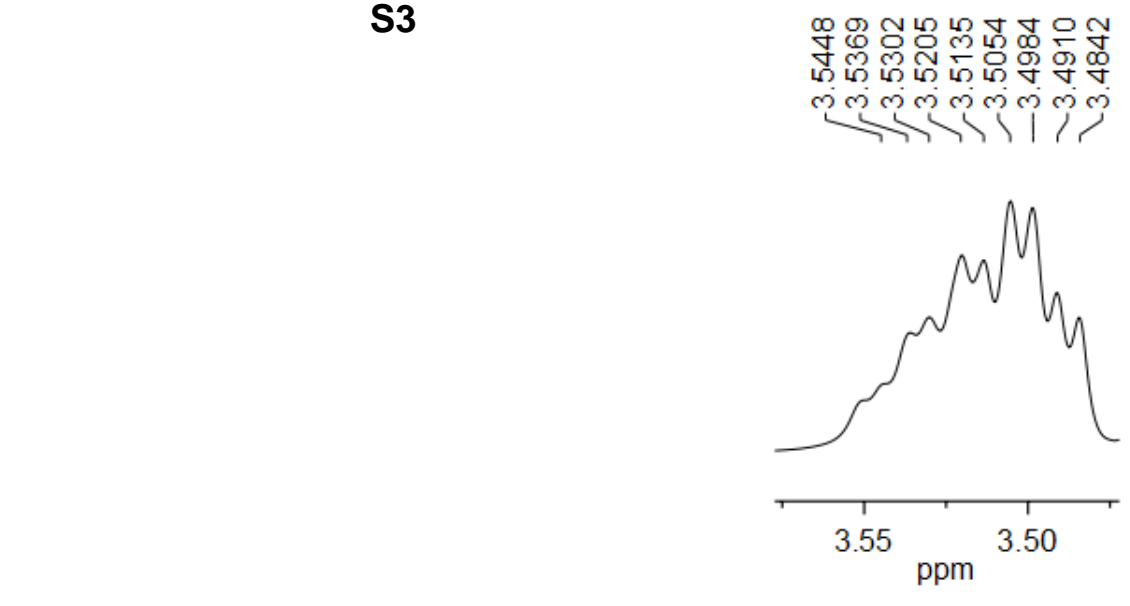

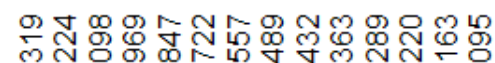
ช จ

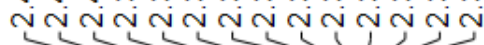
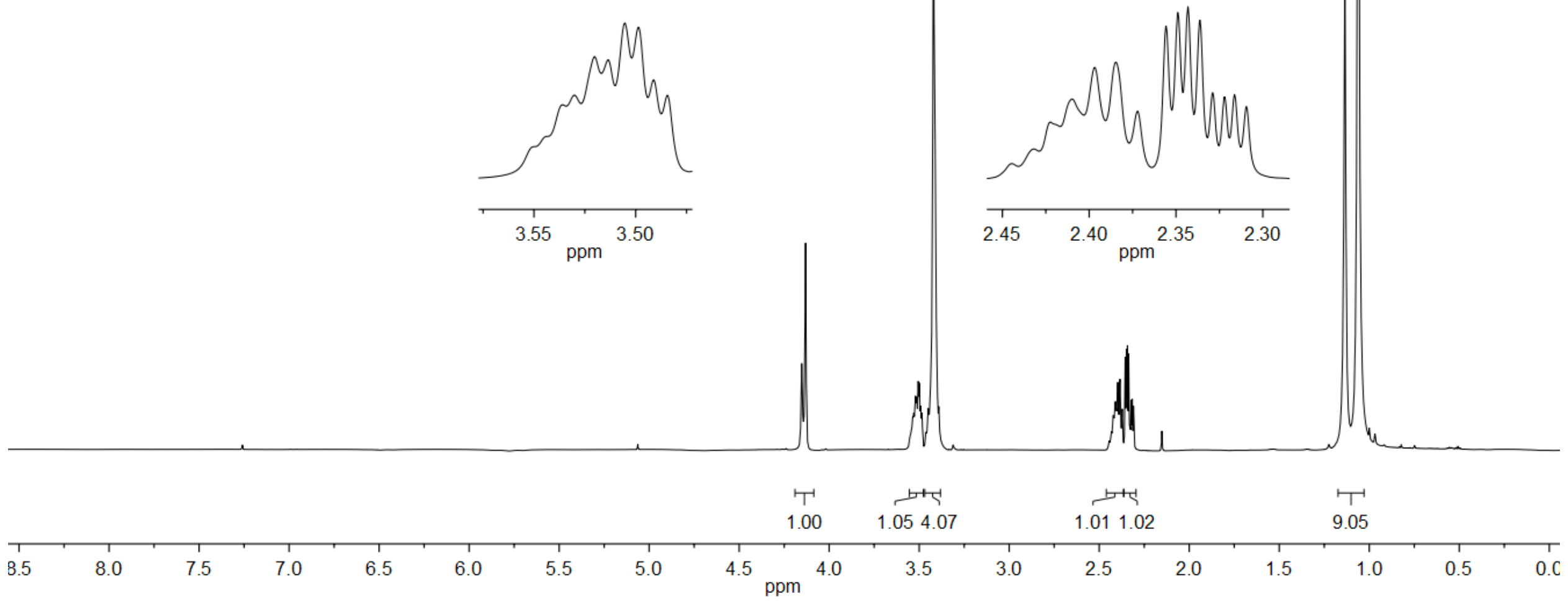
${ }^{13} \mathrm{C}$ NMR $(175 \mathrm{MHz})$

لَ
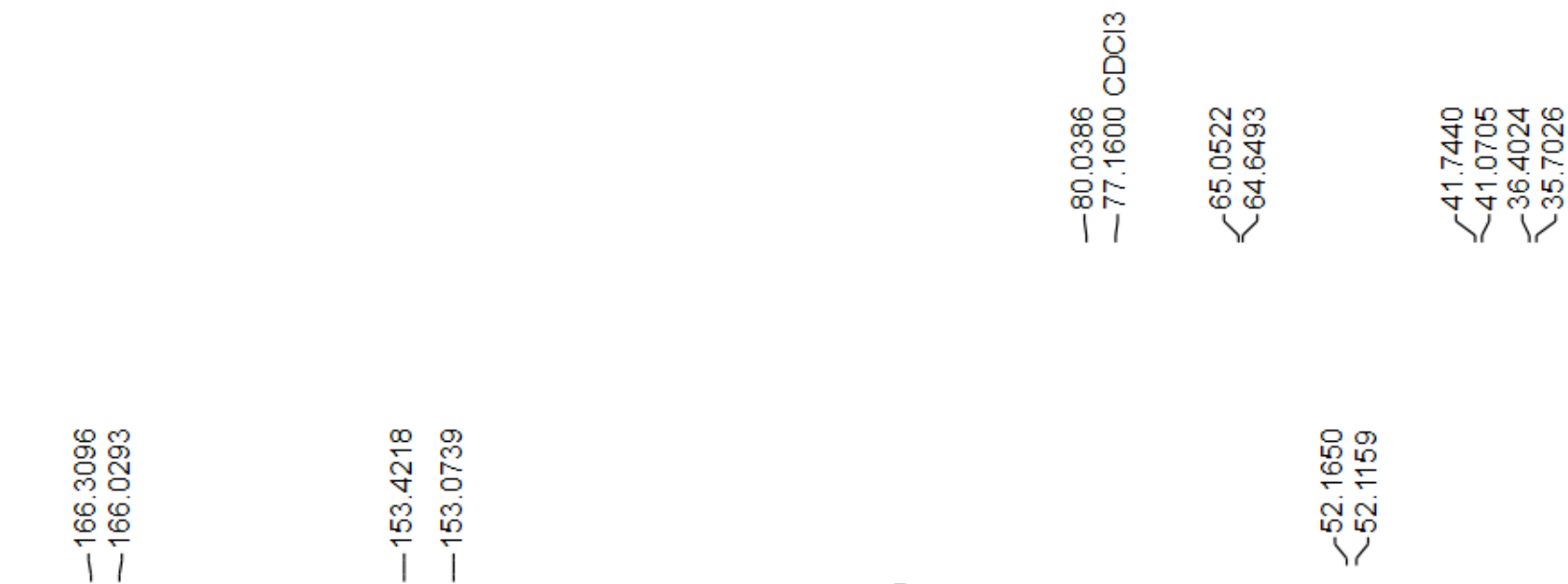

$\stackrel{\infty}{\stackrel{9}{m}}$

ले ले

广
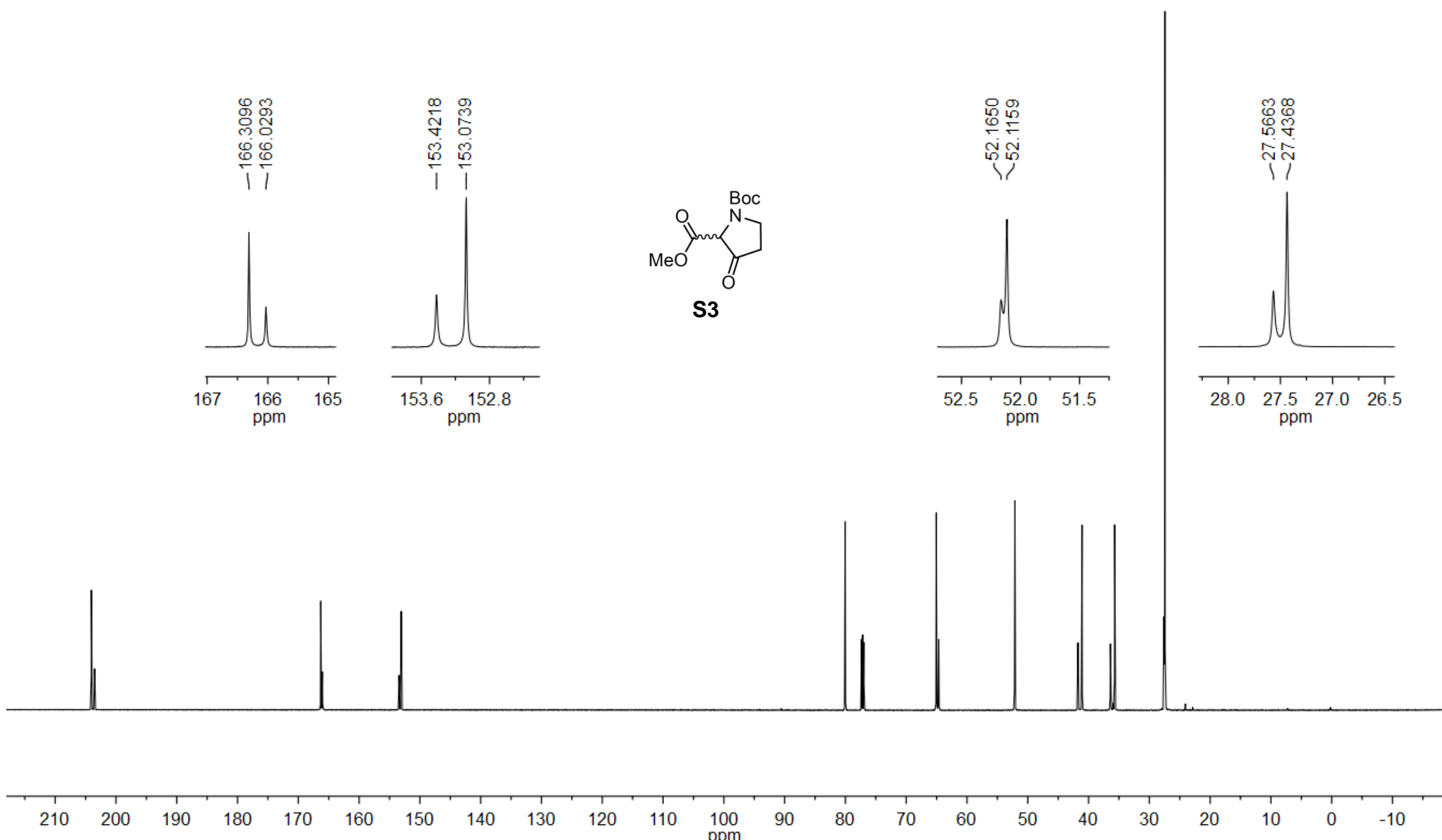

190

180

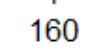

150

$140 \quad 130$

120 
DEPT- $135{ }^{13} \mathrm{C}$ NMR $(175 \mathrm{MHz})$
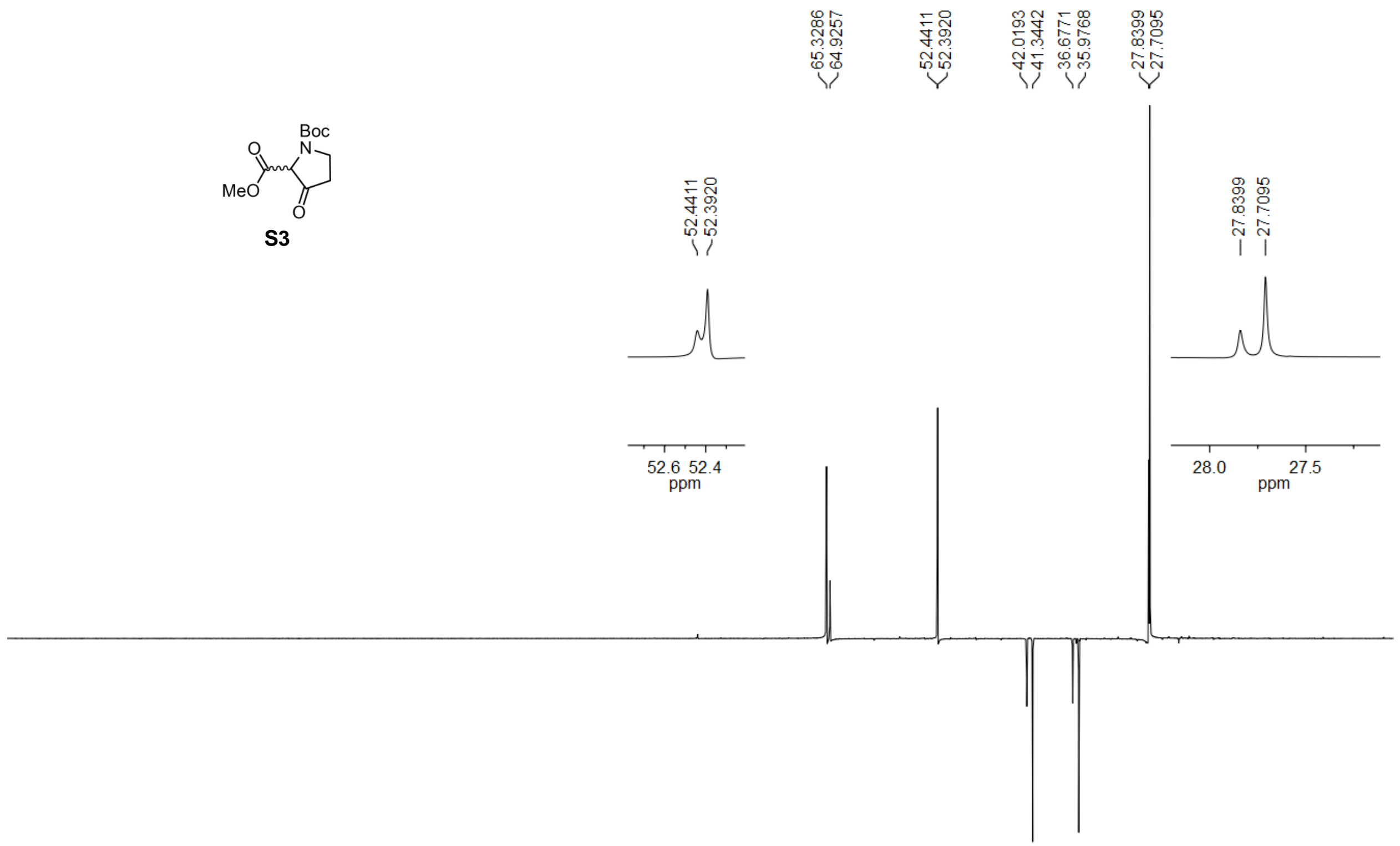


\section{Scheme S2: Synthetic procedures for S4 and 1}

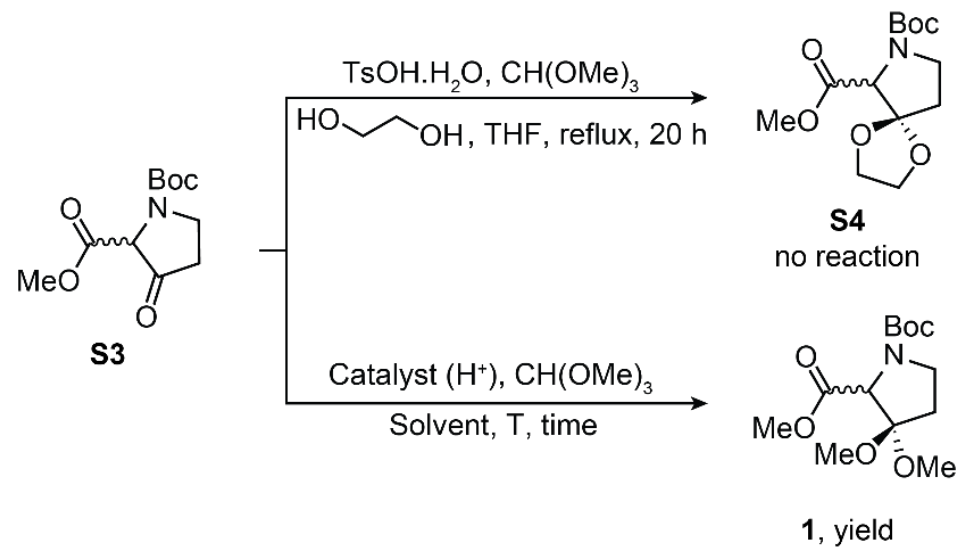<smiles>COC(=O)[C@H]1N(C(=O)OCc2ccccc2)CCC12OCCO2</smiles>

S4

To a solution of $\mathbf{S 3}(1.2 \mathrm{~g}, 4.9 \mathrm{mmol}, 1.0 \mathrm{eq})$ and ethylene glycol $(9.0 \mathrm{~mL}, 145.0 \mathrm{mmol}, 30 \mathrm{eq})$ in dry toluene $(50 \mathrm{~mL})$ was added $\mathrm{p}-\mathrm{TsOH} . \mathrm{H}_{2} \mathrm{O}(100 \mathrm{mg}, 0.53 \mathrm{mmol}, 0.1 \mathrm{eq})$. The reaction mixture was refluxed for $20 \mathrm{~h}$ and analyzed by TLC (30\% EtOAc/hexanes, v/v) and mass spectrometry. Analyses confirmed the presence of unreacted starting material S3 but did not show any formation of S4. Charging the reaction mixture with additional p-TsOH. $\mathrm{H}_{2} \mathrm{O}(100 \mathrm{mg}, 0.53 \mathrm{mmol}, 0.1 \mathrm{eq})$ and refluxing overnight didn't show any product formation as well.

Table A: Optimization conditions for conversion of protection of ketone in 3-oxopyrrolidine derivative S3 via acid catalysis to obtain ketal 1.

\begin{tabular}{|c|c|c|c|c|c|c|}
\hline Catalyst $\left(\mathrm{H}^{+}\right)$ & $\mathrm{CH}(\mathrm{OMe})_{3}$ & Solvent & $\mathrm{T}\left({ }^{\circ} \mathrm{C}\right)$ & Time (h) & Yield (\%) & Comments \\
\hline $\mathrm{pTsOH} . \mathrm{H}_{2} \mathrm{O} 0.1 \mathrm{eq}$ & 9 eq & THF & $\mathrm{rt}$ & 16 & -- & No reaction, Unreacted SM \\
\hline pTsOH. $\mathrm{H}_{2} \mathrm{O} 0.1 \mathrm{eq}$ & 9 eq & THF & 85 & 16 & -- & No reaction, Unreacted SM \\
\hline pTsOH. $\mathrm{H}_{2} \mathrm{O} 0.1 \mathrm{eq}$ & 9 eq & THF & 110 & 24 & -- & No reaction, Unreacted SM \\
\hline pTsOH. $\mathrm{H}_{2} \mathrm{O} 0.2 \mathrm{eq}$ & 9 eq & THF & 110 & 24 & -- & No reaction, Unreacted SM \\
\hline pTsOH. $\mathrm{H}_{2} \mathrm{O} 0.2$ eq & 35 eq & Dry $\mathrm{MeOH}$ & $\mathrm{rt}$ & 16 & 50 & $400 \mathrm{mg}$ scale S3 \\
\hline pTsOH. $\mathrm{H}_{2} \mathrm{O} 0.2 \mathrm{eq}$ & 35 eq & Dry $\mathrm{MeOH}$ & rt & 16 & 40 & $1 \mathrm{~g}$ scale $\mathrm{S3}$ \\
\hline Conc. $\mathrm{H}_{2} \mathrm{SO}_{4} 0.3$ eq & $30 \mathrm{eq}$ & Dry $\mathrm{MeOH}$ & $\mathrm{rt}$ & 14 & 43.7 & $1.0 \mathrm{~g}$ scale $\mathbf{S 3}$ \\
\hline Conc. $\mathrm{H}_{2} \mathrm{SO}_{4} 0.3 \mathrm{eq}$ & 30 eq & Dry $\mathrm{MeOH}$ & $\mathrm{rt}$ & 14 & $50-55$ & $8.0 \mathrm{~g}$ scale of $\mathrm{S} 3$ \\
\hline
\end{tabular}




\section{Scheme S3: Synthetic procedures for 1-7}

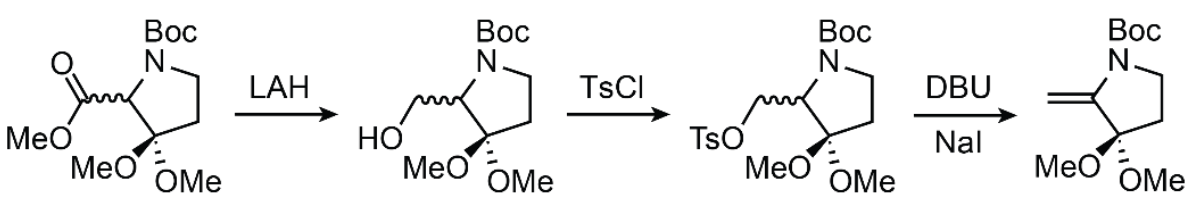

1

2, $87-92 \%$

$3,85-88 \%$

4, 90-95\%

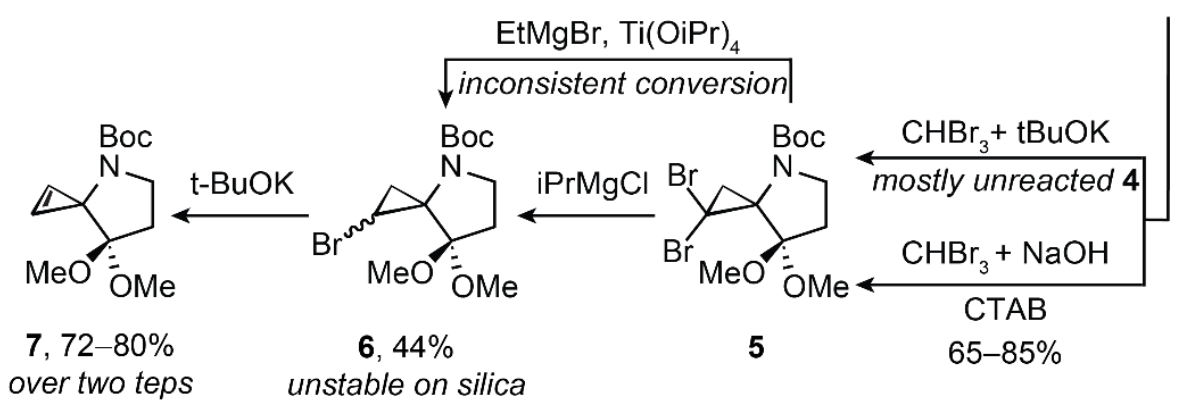

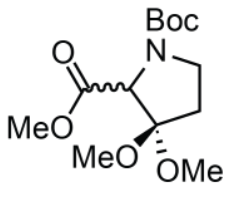

1

To a solution of $\mathbf{S} 3(11.0 \mathrm{~g}, 45.2 \mathrm{mmol}, 1.0 \mathrm{eq})$ in dry $\mathrm{MeOH}(100 \mathrm{~mL})$ and trimethylorthoformate (100 $\mathrm{mL})$ at rt was added conc. $\mathrm{H}_{2} \mathrm{SO}_{4}(920 \mu \mathrm{L})$. After stirring the reaction mixture at the same temperature for 48 hours, $\mathrm{pH}$ of the solution was increased to $9-10$ using $\mathrm{Et}_{3} \mathrm{~N}$. To this solution was added $\mathrm{Boc}_{2} \mathrm{O}$ ( $4.94 \mathrm{~g}, 22.6 \mathrm{mmol}, 0.5 \mathrm{eq})$ and the reaction was stirred overnight at rt, concentrated in vacuo, and diluted with DCM $(100 \mathrm{~mL})$ and water $(100 \mathrm{~mL})$. The aqueous layer was washed with DCM $(3 \times 50$ $\mathrm{mL}$ ) and the combined organic layers were dried over anhydrous $\mathrm{Na}_{2} \mathrm{SO}_{4}$, concentrated in vacuo, and purified by flash chromatography (200 g silica, 20\% EtOAc/hexanes (v/v)) to obtain 1 as a light-yellow oil $(7.0 \mathrm{~g}, 53.5$ $\%$ ) and unreacted starting material. Multiple repetitions of this reaction ( $>5)$ starting from different amounts of S3, on different days, and by three different personnel, provided comparable yields. $\mathrm{R}_{\mathrm{f}}=0.54\left(20 \% \mathrm{EtOAc/hexanes,} \mathrm{visualized} \mathrm{w} / \mathrm{KMnO}_{4}\right.$ stain). ${ }^{1} \mathrm{H}$ NMR (rotamers, $\left.500 \mathrm{MHz}, \mathrm{CDCl}_{3}\right): \delta=4.33(\mathrm{~s}, 0.4 \mathrm{H}), 4.21(\mathrm{~s}, 0.6 \mathrm{H}), 3.66(\mathrm{~d}, \mathrm{~J}=4.5 \mathrm{~Hz}, 3 \mathrm{H}), 3.63-3.54(\mathrm{~m}, 1 \mathrm{H})$, 3.30-3.23 (m, 1H), $3.21(\mathrm{~s}, 3 \mathrm{H}), 3.18(\mathrm{~d}, J=1.6 \mathrm{~Hz}, 3 \mathrm{H}), 2.14-2.00(\mathrm{~m}, 2 \mathrm{H}), 1.34(2 \times \mathrm{s}, 9 \mathrm{H}) .{ }^{13} \mathrm{C}$ NMR (rotamers, $126 \mathrm{MHz}$, $\left.\mathrm{CDCl}_{3}\right): \delta=170.81,170.58,154.27,153.66,108.92,108.07,80.07,63.47,62.54,52.14,51.98,50.79,49.29,49.25,44.11$, 43.56, 32.30, 31.54, 28.33, 28.23. COSY NMR (500 MHz, $\mathrm{CDCl}_{3}$, attached) was obtained under the same conditions. HRMS (ESI): Calcd for $\mathrm{C}_{13} \mathrm{H}_{24} \mathrm{NO}_{6}{ }^{+}[\mathrm{M}+\mathrm{H}]^{+}: 290.1598$, found: 290.1603 .

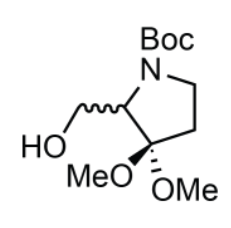

2

To a solution of $1(2.0 \mathrm{~g}, 6.9 \mathrm{mmol}, 1 \mathrm{eq})$ in THF $(30 \mathrm{~mL})$ at ice-cold temperature was added LAH (290 $\mathrm{mg}, 11.62 \mathrm{mmol}, 1.05 \mathrm{eq}$ ) in portions. The suspension was stirred at the same temperature for 40 mins, diluted with DCM and quenched with water. The organic layer was collected and the aqueous layer was extracted with DCM and the combined organic layers were washed with brine, dried over anhydrous $\mathrm{Na}_{2} \mathrm{SO}_{4}$, concentrated in vacuo, and purified by flash chromatography ( $50 \mathrm{~g}$ silica, 40\% EtOAc/hexanes (v/v)) to obtain 2 as a light-yellow oil $(1.7 \mathrm{~g}, 92 \%)$. Another instance of this reaction starting from $4.5 \mathrm{~g}$ of 1 afforded $3.6 \mathrm{~g}$ of $2(88.7 \%)$. Multiple repetitions of this reaction $(>5)$ starting from different amounts of 2 , on different days, and by 3 different personnel, provided comparable yields. $R_{f}=0.35(50 \%$ EtOAc/hexanes, visualized w/ $\mathrm{KMnO}_{4}$ stain). ${ }^{1} \mathrm{H}$ NMR (rotamers, $500 \mathrm{MHz}, \mathrm{CDCl}_{3}$ ): $\delta=4.00$ (t, $J=4.9 \mathrm{~Hz}, 0.5 \mathrm{H}$ ), 3.85 (br s, $0.5 \mathrm{H}$ ), $3.72(\mathrm{dt}$, $J=11.0,5.4 \mathrm{~Hz}, 0.5 \mathrm{H}), 3.59(\mathrm{tt}, J=11.5,5.0 \mathrm{~Hz}, 1.5 \mathrm{H}), 3.45(\mathrm{t}, J=5.6 \mathrm{~Hz}, 0.5 \mathrm{H}), 3.38(\mathrm{t}, J=10.2 \mathrm{~Hz}, 1 \mathrm{H}), 3.30-3.26(\mathrm{~m}$, $4 \mathrm{H}), 3.22(\mathrm{~s}, 3 \mathrm{H}), 2.10-2.04(\mathrm{~m}, 1 \mathrm{H}), 1.99-1.89(\mathrm{~m}, 1 \mathrm{H}), 1.43(\mathrm{~s}, 9 \mathrm{H}) .{ }^{13} \mathrm{C}$ NMR (rotamers, $\left.126 \mathrm{MHz}, \mathrm{CDCl}_{3}\right): \delta=156.06$, $154.61,109.64,108.08,80.18,63.86,62.89,60.75,59.39,50.61,50.54,48.98,48.92,43.85,43.34,32.37,31.47,28.55$, 
28.51. COSY NMR (500 MHz, $\mathrm{CDCl}_{3}$, attached) was obtained under the same conditions. HRMS (ESI): Calcd for $\mathrm{C}_{12} \mathrm{H}_{24} \mathrm{NO}_{5}{ }^{+}[\mathrm{M}+\mathrm{H}]^{+}:$262.1649, found: 262.1655 .

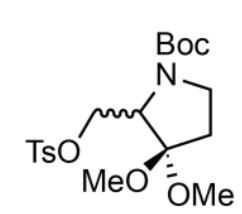

3

To a solution of $2(261.2 \mathrm{mg}, 1.0 \mathrm{mmol}, 1.0 \mathrm{eq})$ in dry pyridine $(10 \mathrm{~mL})$ was added $\mathrm{TsCl}(572 \mathrm{mg}, 3.0$ $\mathrm{mmol}, 3.0 \mathrm{eq}$ ) and the greenish-yellow reaction mixture was stirred at $50{ }^{\circ} \mathrm{C}$ for $20 \mathrm{~h}$. The reaction turned light pink and the reaction was stopped based on TLC/MS analysis. The reaction mixture was concentrated to remove excess pyridine and diluted with DCM and water. DCM layer was collected and the aqueous layer was further washed with DCM. The combined organic layer was dried over anhydrous $\mathrm{Na}_{2} \mathrm{SO}_{4}$, concentrated in vacuo, and purified by flash chromatography (20 g silica, 20\%-

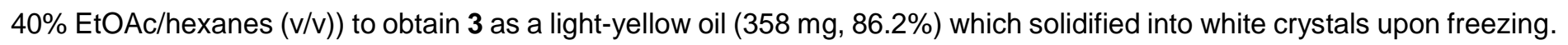
Another instance of this reaction starting from $3.34 \mathrm{~g}$ of 2 afforded $4.5 \mathrm{~g}$ of 3 (84.9\%). Multiple repetitions of this reaction (>5) starting from different amounts of $\mathbf{2}$, on different days, and by 3 different personnel, provided comparable yields.

Alternatively, to a solution of $2(1.66 \mathrm{~g}, 6.35 \mathrm{mmol}, 1 \mathrm{eq})$ in $\mathrm{DCM}(40 \mathrm{~mL})$ was added $\mathrm{TsCl}(1.45 \mathrm{~g}, 7.26 \mathrm{mmol}, 1.2$ eq), $\mathrm{Et}_{3} \mathrm{~N}$ (836 mg, $\left.8.26 \mathrm{mmol}, 1.3 \mathrm{eq}\right)$, and DMAP $(7.76 \mathrm{mg}, 0.064 \mathrm{mmol}, 0.01 \mathrm{eq})$ respectively. The reddish-brown reaction mixture was then heated to $45^{\circ} \mathrm{C}$ and stirred at this temperature for $16 \mathrm{~h}$. The reaction mixture was diluted with water and the DCM layer extracted. The aqueous layer was further washed with DCM $(4 \times 30 \mathrm{~mL})$ and the combined organic layer was washed with brine, dried over anhydrous $\mathrm{Na}_{2} \mathrm{SO}_{4}$, concentrated in vacuo, and purified by flash chromatography (100 $\mathrm{g}$ silica, $20 \%-40 \%$ EtOAc/hexanes $(\mathrm{v} / \mathrm{v}))$ to obtain 3 as a yellow oil $(1.6 \mathrm{~g}, 85 \%)$.

$\mathrm{R}_{\mathrm{f}}=0.25$ (20\% EtOAc/hexanes, visualized w/ UV). ${ }^{1} \mathrm{H}$ NMR (rotamers, $\left.500 \mathrm{MHz}, \mathrm{CDCl}_{3}\right): \delta=7.65(\mathrm{~d}, J=8.3 \mathrm{~Hz}$, 2H), 7.25-7.22 (m, 2H), $4.27(\mathrm{~d}, J=7.9 \mathrm{~Hz}, 1 \mathrm{H}), 4.10(\mathrm{~d}, J=6.6 \mathrm{~Hz}, 1 \mathrm{H}) .3 .93-3.81(\mathrm{~m}, 2 \mathrm{H}), 3.30-3.14(\mathrm{~m}, 2 \mathrm{H}), 3.04(\mathrm{~d}, J$ $=8.5 \mathrm{~Hz}, 6 \mathrm{H}), 2.32(\mathrm{~s}, 3 \mathrm{H}), 1.97-1.78(\mathrm{~m}, 2 \mathrm{H}), 1.30(2 \times \mathrm{s}, 9 \mathrm{H}) .{ }^{13} \mathrm{C} \mathrm{NMR}\left(126 \mathrm{MHz}, \mathrm{CDCl}_{3}\right) \delta=154.22,153.95,144.60$, 144.39, 132.95, 132.78, 129.66, 129.60, 127.69, 107.19, 106.52, 79.91, 79.58, 68.06, 67.48, 58.06, 57.71, 50.45, 50.34, 48.51, 43.65, 43.01, 32.54, 31.25, 28.19, 28.14, 21.41. COSY NMR (500 MHz, CDCl 3 , attached) was obtained under the same conditions. HRMS (ESI): Calcd for $\mathrm{C}_{19} \mathrm{H}_{29} \mathrm{NO}_{7} \mathrm{SNa}[\mathrm{M}+\mathrm{Na}]^{+}: 415.1557$, found: 438.1566 .

Table B: Optimization conditions for tosyl activation of alcohol $\mathbf{3}$ to $\mathbf{4}$.

\begin{tabular}{llcccl} 
TsCl (eq) & Solvent & $\mathbf{T ~}\left({ }^{\circ} \mathbf{C}\right)$ & Time $(\mathbf{h})$ & Yield $(\%)$ & Comments \\
\hline 1.2 & DCM & rt & $16-24$ & $45-50$ & Unreacted 3 was recovered \\
1.2 & DCM & 45 & 16 & 85 & Some unreacted 3 \\
3.0 & Pyridine & 50 & 20 & 86.2 &
\end{tabular}

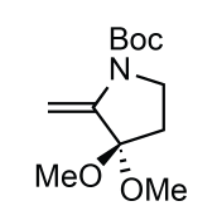

4

This alkene synthesis was based on our recently reported general method for synthesis of these kind of enamines ${ }^{4}$. To a solution of $3(4.8 \mathrm{~g}, 11.56 \mathrm{mmol}, 1 \mathrm{eq})$ in glyme $(80 \mathrm{~mL})$ was sequentially added $\mathrm{Nal}$ (5.2 g, $34.69 \mathrm{mmol}, 3 \mathrm{eq})$, and DBU (3.5 g, $23.13 \mathrm{mmol}, 2 \mathrm{eq})$. The reaction mixture was refluxed $\left(105^{\circ} \mathrm{C}\right)$ for $4 \mathrm{~h}$ and quenched with water $(20 \mathrm{~mL})$. The reaction mixture was concentrated to remove excess glyme and diluted with $\mathrm{Et}_{2} \mathrm{O}(50 \mathrm{~mL})$. The ether layer was washed with water $(2 \mathrm{x})$, saturated $\mathrm{NaHCO}_{3}(2 \mathrm{x})$, and brine (1x). The ether layer was then dried over anhydrous $\mathrm{Na}_{2} \mathrm{SO}_{4}$, concentrated in vacuo, and used directly without any further purification to obtain 4 as a pale-yellow oil ( $3.0 \mathrm{~g}$, quantitative) that was stable for at least 6 months upon storage at $-20^{\circ} \mathrm{C}$. Another instance of this reaction starting from $2.3 \mathrm{~g}$ of 2 afforded $1.2 \mathrm{~g}$ of 3 (quantitative). Multiple repetitions of this reaction $(>5)$ starting from different amounts of $\mathbf{3}$, on different days, and by 3 different personnel, provided comparable yields. $\mathrm{R}_{\mathrm{f}}=0.88$ (20\% EtOAc/hexanes, visualized w/ UV). ${ }^{1} \mathrm{H} \mathrm{NMR}(500 \mathrm{MHz}$, 
$\left.\mathrm{CDCl}_{3}\right) \delta=5.40(\mathrm{br} \mathrm{s}, 1 \mathrm{H}), 4.43(\mathrm{~s}, 1 \mathrm{H}), 3.36(\mathrm{t}, J=6.9 \mathrm{~Hz}, 2 \mathrm{H}), 3.06(\mathrm{~s}, 6 \mathrm{H}), 1.83(\mathrm{t}, J=6.9 \mathrm{~Hz}, 2 \mathrm{H}), 1.34(\mathrm{~s}, 9 \mathrm{H}) .{ }^{13} \mathrm{C} \mathrm{NMR}$ $\left(126 \mathrm{MHz}, \mathrm{CDCl}_{3}\right): \delta=152.28,140.79,104.01,92.42,80.15,49.33,44.61,32.18,28.06$. COSY NMR $\left(500 \mathrm{MHz} \mathrm{CDCl}_{3}\right.$, attached) was obtained under the same conditions. HRMS (ESI): Calcd for $\mathrm{C}_{12} \mathrm{H}_{22} \mathrm{NO}_{4}[\mathrm{M}+\mathrm{H}]^{+}: 244.1543$ found: 244.1548.

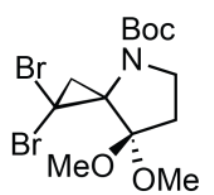

5

To a solution of 4 (615 mg, $2.53 \mathrm{mmol}, 1 \mathrm{eq})$ in $\mathrm{CHBr}_{3}(906 \mu \mathrm{L}, 2.56 \mathrm{~g}, 10.12 \mathrm{mmol}, 4 \mathrm{eq})$ was added CTAB (138.3 mg, $0.38 \mathrm{mmol}, 0.15 \mathrm{eq}$ ) and the mixture was stirred vigorously while being protected from light. To this reaction mixture was dropwise added aqueous $\mathrm{NaOH}(443 \mu \mathrm{L}, 50 \% \mathrm{w} / \mathrm{v}, 25 \mathrm{M})$ and the reaction was stirred overnight at the same temperature. MS analysis of TLC scratch $\left(R_{f}\right.$ values of 4 and 3 are identical) showed presence of both 4 and 5 . This brown reaction mixture was then charged with additional $\mathrm{CHBr}_{3}(2 \mathrm{eq}), \mathrm{CTAB}(0.15 \mathrm{eq})$, and $\mathrm{NaOH}(443 \mu \mathrm{L})$ and stirred for another 8 $\mathrm{h}$ for complete consumption of the alkene. Complete consumption of reactant, $\mathbf{4}$, was a necessity to obtain high-purity product, $\mathbf{5}$, as the product have same $\mathrm{R}_{\mathrm{f}}$ as the reactant. Upon completion, the reaction mixture was diluted with DCM and water. The organic layer was collected, washed with brine, concentrated in vacuo, and purified by flash chromatography (24 g silica, 0\%-5\% EtOAc/hexanes $(\mathrm{v} / \mathrm{v})$ ) to obtain 5 as a yellow oil (685 mg, 65.2\%). Separate instances of this reaction starting from $685 \mathrm{mg}, 885 \mathrm{mg}, 2.21 \mathrm{~g}$ of 4 afforded $5 \mathrm{in} 980 \mathrm{mg}(84 \%), 1.12 \mathrm{~g}(74.2 \%)$, and $2.44 \mathrm{~g}(64.7 \%)$ yields respectively. Multiple repetitions of this reaction $(>5)$ starting from different amounts of 4 , on different days, and by 3 different personnel, provided varied yields between $65-85 \%$.

A separate test reaction using KOtBu was conducted: To a solution of 4 (149 mg, $0.613 \mathrm{mmol}, 1.0 \mathrm{eq})$ and $\mathrm{CHBr}_{3}$ (68.3 $\mu \mathrm{L}, 186 \mathrm{mg}, 0.74 \mathrm{mmol}, 1.2 \mathrm{eq})$ in hexanes $(6 \mathrm{~mL})$ at $-10{ }^{\circ} \mathrm{C}$ was added KOtBu (96.3 mg, $\left.0.86 \mathrm{mmol}, 1.4 \mathrm{eq}\right)$. The reaction was allowed to warm to rt and hexanes. MS analysis of TLC scratch after $1 \mathrm{~h}$ showed formation of 5 . Additional $\mathrm{CHBr}_{3}(300 \mu \mathrm{L}, 5.3 \mathrm{eq})$ was added and the reaction was stirred overnight at rt. MS analysis of TLC scratch next morning showed no significant change, hence, additional KOtBu (100 mg, $1.4 \mathrm{eq})$ was added and the reaction was stirred for $48 \mathrm{~h}$ at rt. Again, MS analysis of TLC scratch showed no significant change; therefore, the reaction was quenched and discarded.

$\mathrm{R}_{\mathrm{f}}=0.68\left(20 \%\right.$ EtOAc/hexanes, visualized w/ UV). ${ }^{1} \mathrm{H}$ NMR $\left(500 \mathrm{MHz}, \mathrm{CDCl}_{3}\right): \delta=3.73(\mathrm{q}, \mathrm{J}=9.3 \mathrm{~Hz}, 0.5 \mathrm{H}), 3.61$ (q, $J=9.3 \mathrm{~Hz}, 0.5 \mathrm{H}), 3.50(\mathrm{~d}, J=9.5 \mathrm{~Hz}, 0.5 \mathrm{H}), 3.45-3.38(\mathrm{~m}, 1 \mathrm{H}), 3.29(\mathrm{~s}, 3 \mathrm{H}), 3.18(\mathrm{~d}, J=21.2 \mathrm{~Hz}, 3 \mathrm{H}), 3.03(\mathrm{~d}, J=9.3$ $\mathrm{Hz}, 0.5 \mathrm{H}), 2.34(\mathrm{t}, J=10.4 \mathrm{~Hz}, 1 \mathrm{H}), 2.11(\mathrm{q}, J=9.8 \mathrm{~Hz}, 1 \mathrm{H}), 1.92(\mathrm{p}, J=9.7 \mathrm{~Hz}, 1 \mathrm{H}), 1.42(\mathrm{~d}, J=6.4 \mathrm{~Hz}, 9 \mathrm{H}) .{ }^{13} \mathrm{C} \mathrm{NMR}$ $\left(126 \mathrm{MHz}, \mathrm{CDCl}_{3}\right): \delta=154.45,154.18,103.13,103.09,80.95,80.04,52.35,52.32,50.44,50.37,49.69,49.32,44.00,43.23$, $36.75,30.77,30.69,30.13,29.88,29.71,28.59,28.51$. COSY NMR (500 MHz, $\mathrm{CDCl}_{3}$, attached) was obtained under the same conditions. ${ }^{13} \mathrm{C}$ DEPT-135 NMR (126 MHz, CDCl $)$ ): $\delta$ (up) 50.34, 50.26, 49.59, 49.21, 28.49, 28.41 (down) 43.90, 43.12, 30.66, 30.02, 29.61. HRMS (ESI): Calcd for $\mathrm{C}_{13} \mathrm{H}_{21} \mathrm{Br}_{2} \mathrm{NO}_{4} \mathrm{Na}[\mathrm{M}+\mathrm{Na}]^{+}:$437.9709, found: 437.9718.

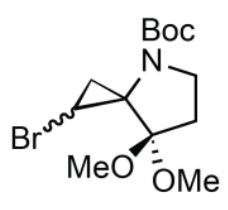

6

To a solution of $5(980 \mathrm{mg}, 2.36 \mathrm{mmol}, 1.0 \mathrm{eq})$ in anhydrous $\mathrm{DCM}(50 \mathrm{~mL})$ at $-78{ }^{\circ} \mathrm{C}$ under $\mathrm{N}_{2}$ was dropwise added $2 \mathrm{M}$ iPrMgCl $(1.4 \mathrm{~mL}, 2.83 \mathrm{mmol}, 1.2 \mathrm{eq})$. The reaction mixture was stirred for 15 mins and quenched by saturated $\mathrm{NH}_{4} \mathrm{Cl}$ at the same temperature. The reaction was transferred to rt and diluted with water. DCM layer was collected and the aqueous layer was further washed with DCM (2x). The combined organic layer was dried over anhydrous $\mathrm{Na}_{2} \mathrm{SO}_{4}$, concentrated in vacuo $\left(\sim 20^{\circ} \mathrm{C}\right)$, and used for next step without further purification. We found this molecule to be unstable on silica.

Column purification produced 6 and hydrolyzed product S5. Moreover, concentrating the column purified 6 under reduced pressure resulted in generation of deep blue colour with baseline spots on the TLC. Hence, we decided to use this molecule without column purification for future reactions.

Separate reactions using EtMgBr to obtain 6 from 5 were also tested: To an ice-cold solution of 5 (150 mg, 0.36 $\mathrm{mmol}, 1.0 \mathrm{eq})$ in dry THF $(3 \mathrm{~mL})$ was added Ti(OiPr) $4(10.7 \mu \mathrm{L}, 10.3 \mathrm{mg}, 0.036 \mathrm{mmol}, 0.1 \mathrm{eq})$ and $3 \mathrm{M}$ (in $\left.\mathrm{Et}_{2} \mathrm{O}\right) \mathrm{EtMgBr}(145$ $\mu \mathrm{L}, 0.43 \mathrm{mmol}, 1.2 \mathrm{eq}$ ) respectively. MS analysis of the crude after 20 mins suggested only starting material, therefore, the 
reaction was transferred to rt. Based on MS after 45 mins, additional $3 \mathrm{M} \mathrm{EtMgBr}(100 \mu \mathrm{L})$ was added. Further MS analysis of the crude after additional EtMgBr showed presence of both starting material and product. Continuing the reaction for another $3 \mathrm{~h}$ did not show any significant improvement in the product concentration. Hence, the reaction was charged with more $\mathrm{EtMgBr}(100 \mu \mathrm{L})$ and $\mathrm{Ti}(\mathrm{OiPr}) 4(11 \mu \mathrm{L})$. This process was repeated every 30 mins till complete consumption of the starting material was observed. Complete conversion of the starting material is necessary as both $\mathbf{5}$ and $\mathbf{6}$ have identical $\mathrm{R}_{\mathrm{f}}$. Upon completion the reaction was quenched with saturate $\mathrm{NH}_{4} \mathrm{Cl}$ and diluted with $\mathrm{DCM}$. The organic layer was collected, dried over anhydrous $\mathrm{Na}_{2} \mathrm{SO}_{4}$, concentrated in vacuo, and purified by flash chromatography (5\% EtOAc/hexanes (v/v)) to obtain semi-pure $\mathbf{6}$, and $\mathrm{S} 5$ as an oil.

$\mathrm{R}_{\mathrm{f}}=0.68\left(20 \%\right.$ EtOAc/hexanes, visualized w/ UV). ${ }^{1} \mathrm{H}$ NMR $\left(6,500 \mathrm{MHz}, \mathrm{CDCl}_{3}\right): \delta=3.76$ (br s, $\left.0.5 \mathrm{H}\right), 3.63$ (br s, $0.5 \mathrm{H}$ ), $3.45(\mathrm{~d}, J=11.2 \mathrm{~Hz}, 1 \mathrm{H}), 3.25(\mathrm{~s}, 3 \mathrm{H}), 3.22(\mathrm{br} \mathrm{s}, 3 \mathrm{H}), 3.10(\mathrm{dd}, J=8.6,5.0 \mathrm{~Hz}, 1 \mathrm{H}), 2.97(\mathrm{~s}, 0.5 \mathrm{H}), 2.44(\mathrm{br} \mathrm{s}$, $0.5 \mathrm{H}$ ),2.13-2.04 (m, 1H), $1.88(\mathrm{t}, J=8.5 \mathrm{~Hz}, 1 \mathrm{H}), 1.81$ (ddd, $J=11.9,10.3,8.9 \mathrm{~Hz}, 1 \mathrm{H}), 1.47(\mathrm{~s}, 9 \mathrm{H})$. COSY NMR (500 $\mathrm{MHz}, \mathrm{CDCl}_{3}$, attached) was obtained under the same conditions. MS (ESI): Calcd for $\mathrm{C}_{8} \mathrm{H}_{12} \mathrm{BrNO}_{3}\left[\mathrm{M}-\mathrm{OMe}-\mathrm{C}\left(\mathrm{CH}_{3}\right)_{3}+\mathrm{H}\right]^{+}$ :248.0, found: $248.0,250.0$.

${ }^{1} \mathrm{H} \operatorname{NMR}\left(\mathrm{S} 5,500 \mathrm{MHz}, \mathrm{CDCl}_{3}\right): \delta=4.39(\mathrm{t}, J=10.7 \mathrm{~Hz}, 1 \mathrm{H}), 3.50$ (ddd, $\left.J=11.5,10.3,7.6 \mathrm{~Hz}, 1 \mathrm{H}\right), 3.16(\mathrm{dd}, J=$ 8.5, 5.6 Hz, 1H), $2.62(\mathrm{dt}, J=18.4,10.1 \mathrm{~Hz}, 1 \mathrm{H}), 2.52$ (ddd, $J=18.5,7.6,2.1 \mathrm{~Hz}, 1 \mathrm{H}), 2.09(\mathrm{dd}, J=8.5,7.4 \mathrm{~Hz}, 1 \mathrm{H}), 1.62$

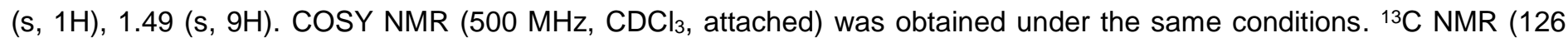
$\left.\mathrm{MHz}, \mathrm{CDCl}_{3}\right): \delta=209.21,153.82,81.42,51.27,42.99,35.60,29.45,28.48,28.46,21.31 .{ }^{13} \mathrm{C}$ DEPT $135 \mathrm{NMR}(126 \mathrm{MHz}$, $\left.\mathrm{CDCl}_{3}\right): \delta=209.21,153.82,81.42,51.27,42.99,35.60,29.45,28.48,28.46,21.31 . \mathrm{MS}$ (ESI): Calcd for $\mathrm{C}_{7} \mathrm{H}_{9} \mathrm{BrNO}_{3}[\mathrm{M}-$ $\left.\mathrm{C}\left(\mathrm{CH}_{3}\right)_{3}+2 \mathrm{H}\right]^{+}:$:234.0, found: 234.0, 236.0.

Table C: Optimization conditions for Grignard reagent mediated mono-bromo formation from 5

\begin{tabular}{|c|c|c|c|c|c|c|}
\hline Grignard reagent & $\mathrm{Ti}(\mathrm{OiPr})_{4}$ & Solvent & $\mathrm{T}\left({ }^{\circ} \mathrm{C}\right)$ & Time & Yield (\%) & Comments \\
\hline $\mathrm{EtMgBr}(1.2 \mathrm{eq})$ & $0.1 \mathrm{eq}$ & Dry THF & $0-4$ & $20 \mathrm{~min}$ & -- & No reaction, Unreacted $\mathbf{5}$ \\
\hline $\mathrm{EtMgBr}(1.2 \mathrm{eq})$ & $0.1 \mathrm{eq}$ & Dry THF & $\mathrm{rt}$ & $45 \min$ & -- & Unreacted 5 , and 6 \\
\hline $\mathrm{EtMgBr}(1.5 \mathrm{eq})$ & $0.2 \mathrm{eq}$ & Dry THF & $\mathrm{rt}$ & $45 \mathrm{~min}$ & 25 & No $5,6+$ S5 upon column \\
\hline $\mathrm{EtMgBr}(1.2 \mathrm{eq})$ & $0.1 \mathrm{eq}$ & Dry THF & $\mathrm{rt}$ & $4 \mathrm{~h}$ & 21 & No $5,6+$ S5 upon column \\
\hline
\end{tabular}

every $0.5 \mathrm{~h}$

$\operatorname{PrMgCl}(1.2$ eq)

iPrMgCl (1.2 eq) every $0.5 \mathrm{~h}$

Dry DCM $\quad-78 \quad 11-15 \mathrm{~min} \quad 44$

Dry DCM

$-78>15 \mathrm{~min}$
No 5, 6 upon column No 5 or 6

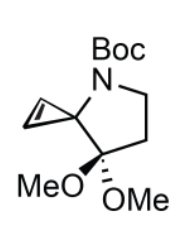

7

Crude 6 from the previous step was dissolved in THF $(50.0 \mathrm{~mL})$ and cooled down to $-78^{\circ} \mathrm{C}$. To this solution was added KOtBu (529.8 mg, $4.72 \mathrm{mmol}$, 2eq) and the reaction was allowed to gradually warm to rt overnight. The yellow-orange reaction was quenched with saturate $\mathrm{NH}_{4} \mathrm{Cl}$, concentrated in vacuo, and diluted with DCM. The organic layer was collected and the aqueous layer was further washed with DCM. The combined organic layer was dried over anhydrous $\mathrm{Na}_{2} \mathrm{SO}_{4}$, concentrated in vacuo, and purified by flash chromatography (30 g silica, 20\% EtOAc/hexanes(v/v)) to obtain 7 (431 $\mathrm{mg}, 72 \%$ over two steps) as a pale-yellow oil. Multiple repetitions of this reaction $(>5)$ starting from different amounts of $\mathbf{6}$, on different days, and by two different personnel, provided comparable yields. $\mathrm{R}_{f}=0.26(20 \% \mathrm{EtOAc/hexanes,} \mathrm{visualized}$ w/ $\left.\mathrm{KMnO}_{4}\right) .{ }^{1} \mathrm{H}$ NMR $\left(500 \mathrm{MHz}, \mathrm{CDCl}_{3}\right): \delta=7.43-6.83(\mathrm{~m}, 2 \mathrm{H}), 3.29(\mathrm{t}, J=7.1 \mathrm{~Hz}, 2 \mathrm{H}), 3.15(\mathrm{~s}, 6 \mathrm{H}), 1.90(\mathrm{t}, J=7.4 \mathrm{~Hz}$, $2 \mathrm{H}), 1.31(\mathrm{~s}, 9 \mathrm{H}) .{ }^{13} \mathrm{C} \mathrm{NMR}\left(126 \mathrm{MHz}, \mathrm{CDCl}_{3}\right): \delta={ }^{13} \mathrm{C} \mathrm{NMR}\left(126 \mathrm{MHz}, \mathrm{CDCl}_{3}\right) \delta 154.78,113.39,102.25,78.99,49.79$, 45.99, 41.51, 31.75, 28.43. COSY NMR (500 MHz, $\mathrm{CDCl}_{3}$, attached) was obtained under the same conditions. HRMS (ESI): Calcd for $\mathrm{C}_{13} \mathrm{H}_{21} \mathrm{NO}_{4} \mathrm{Na}[\mathrm{M}+\mathrm{Na}]^{+}: 278.1363$, found: 278.1373 . 
${ }^{1} \mathrm{H}$ NMR $(500 \mathrm{MHz})$

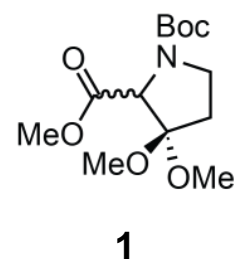

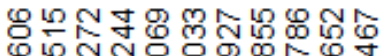
810068

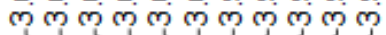

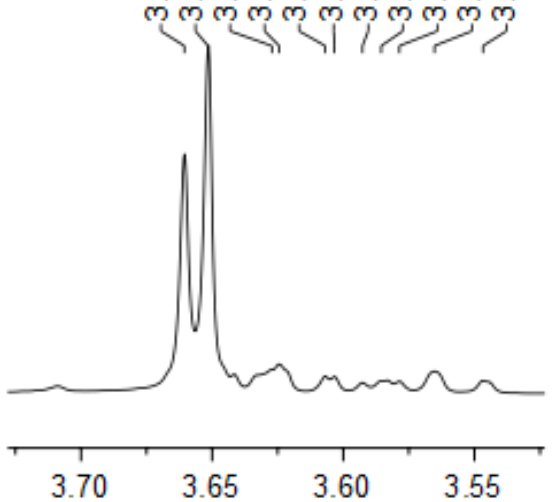

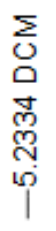

\section{กิำ i}

๘

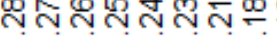

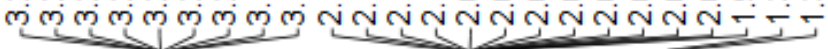
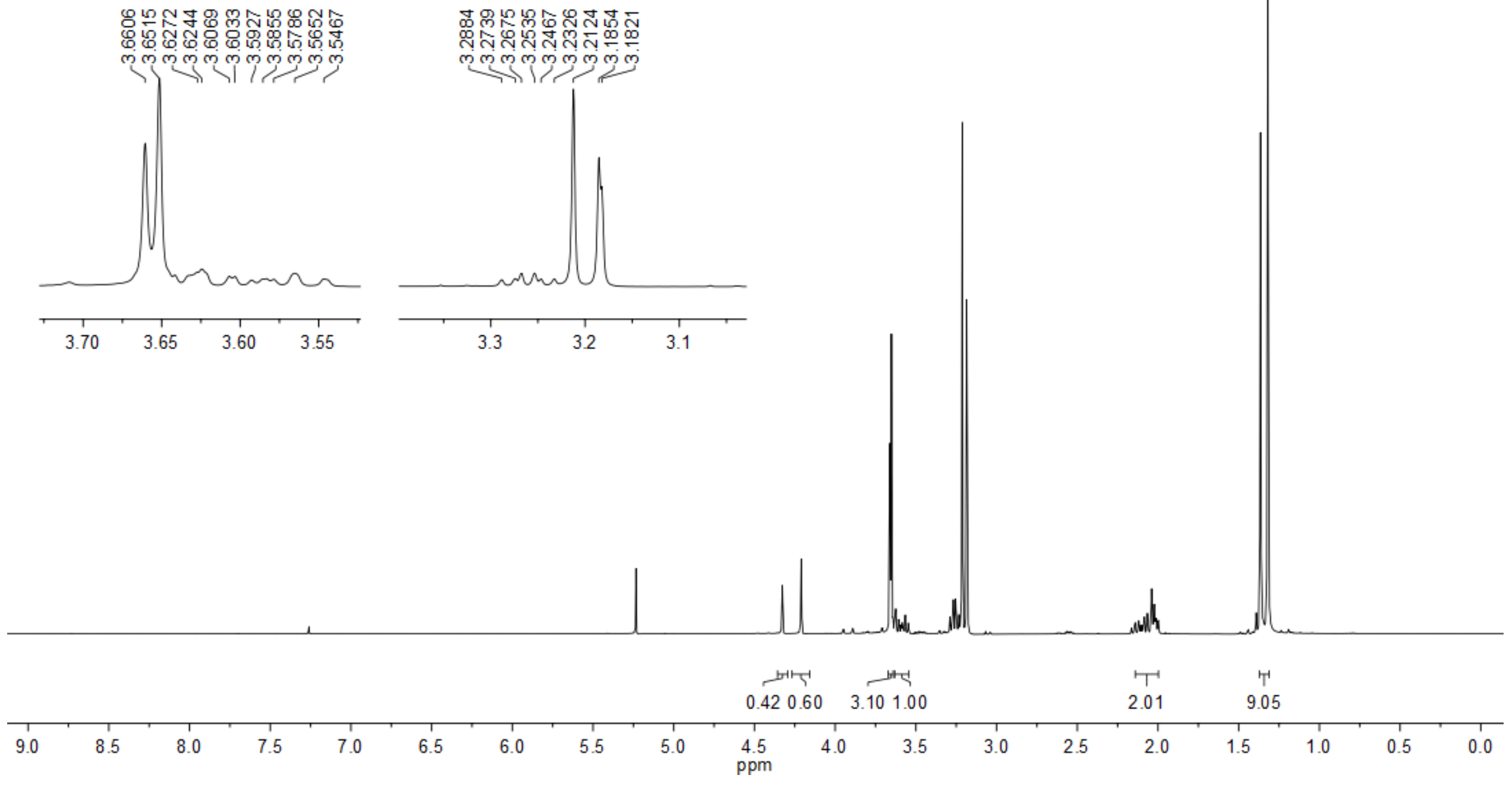

[19] 
${ }^{13} \mathrm{C}$ NMR (126 MHz)<smiles>COC(=O)[C@@H]1[C@@H](OC)CC[C@]1(OC)OC(=O)c1ccccc1</smiles>

1

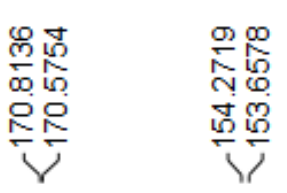

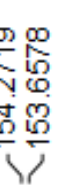

$\frac{N}{5}$
$\frac{5}{0}$
1.

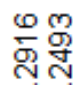

กิ

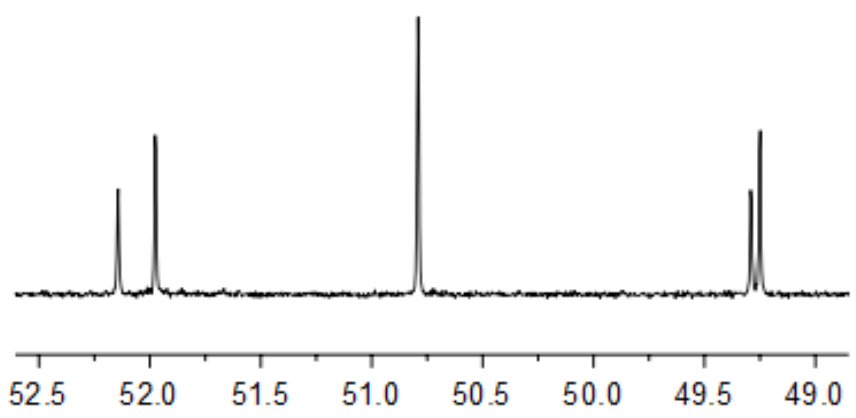

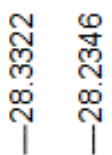

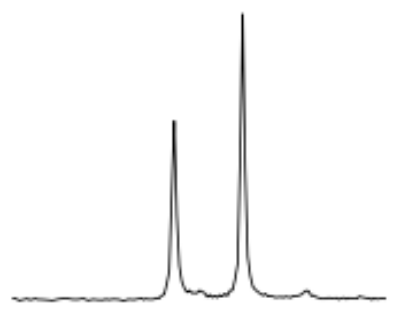

285284283282281

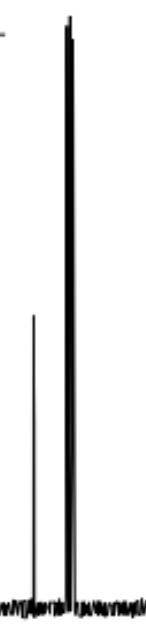


COSY NMR (500 MHz)

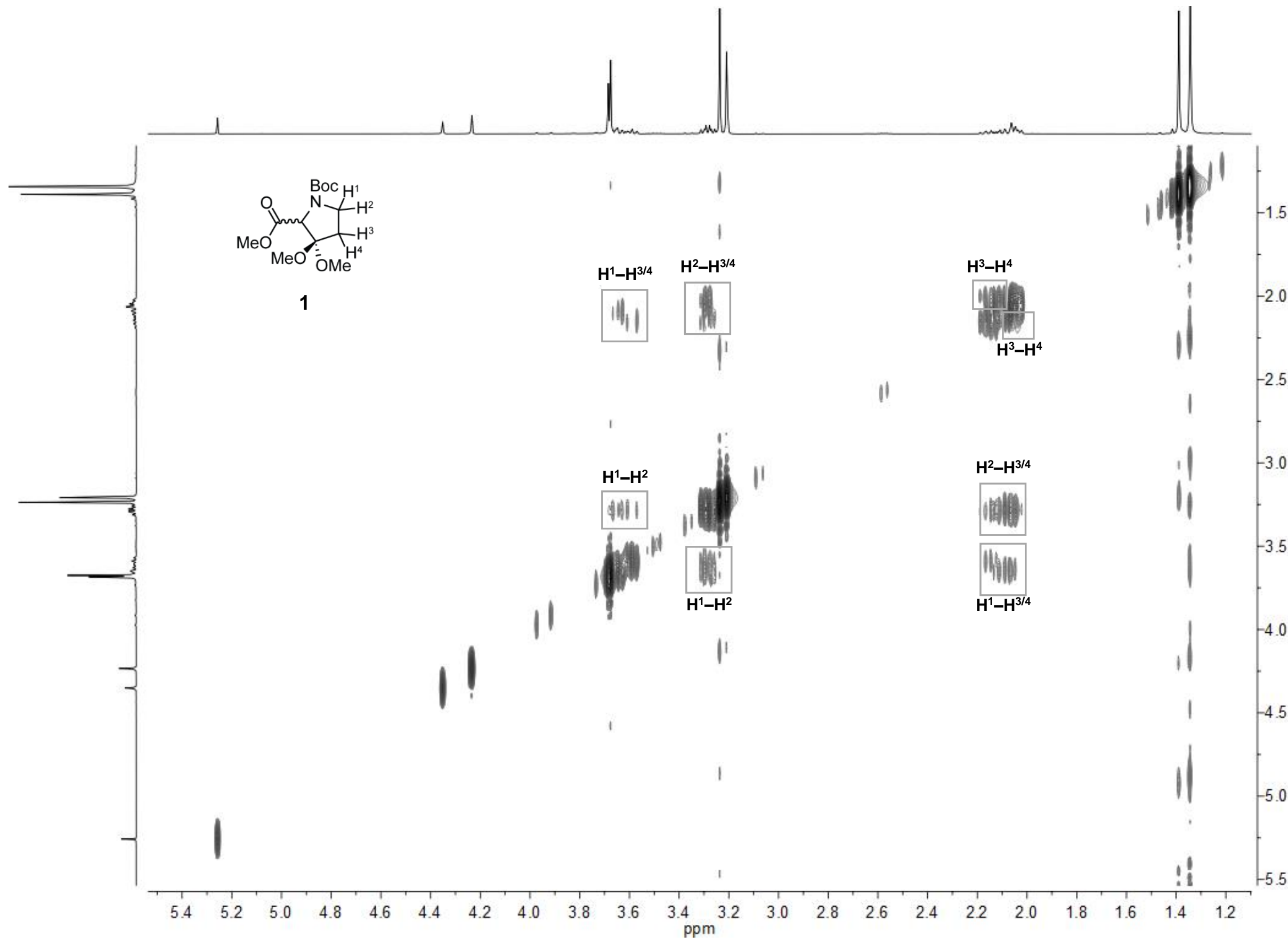

틈 


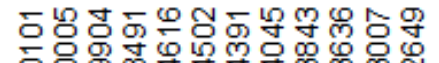

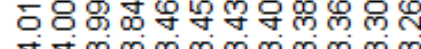

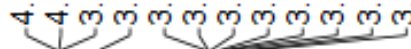
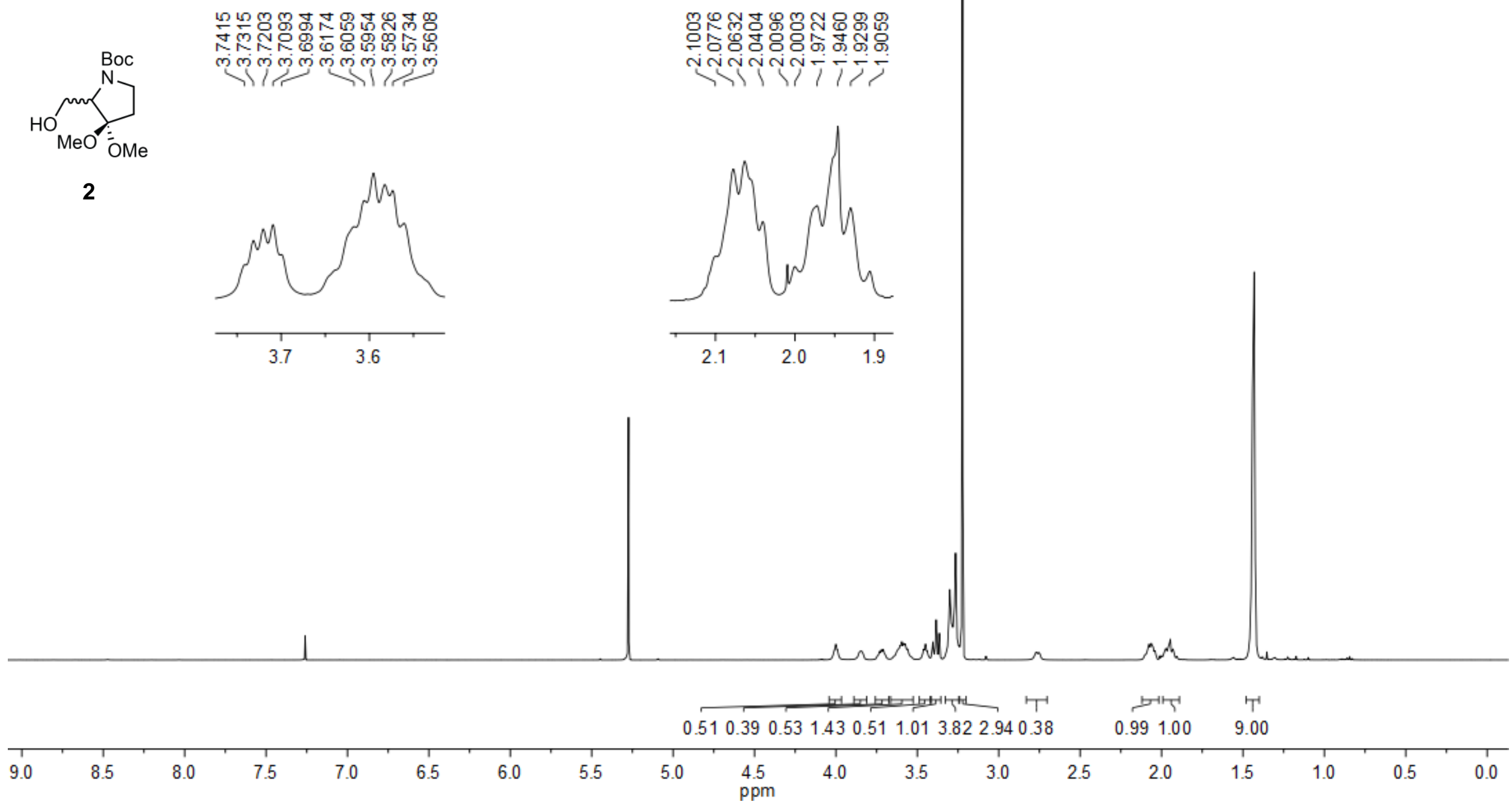
${ }^{13} \mathrm{C}$ NMR $(126 \mathrm{MHz})$

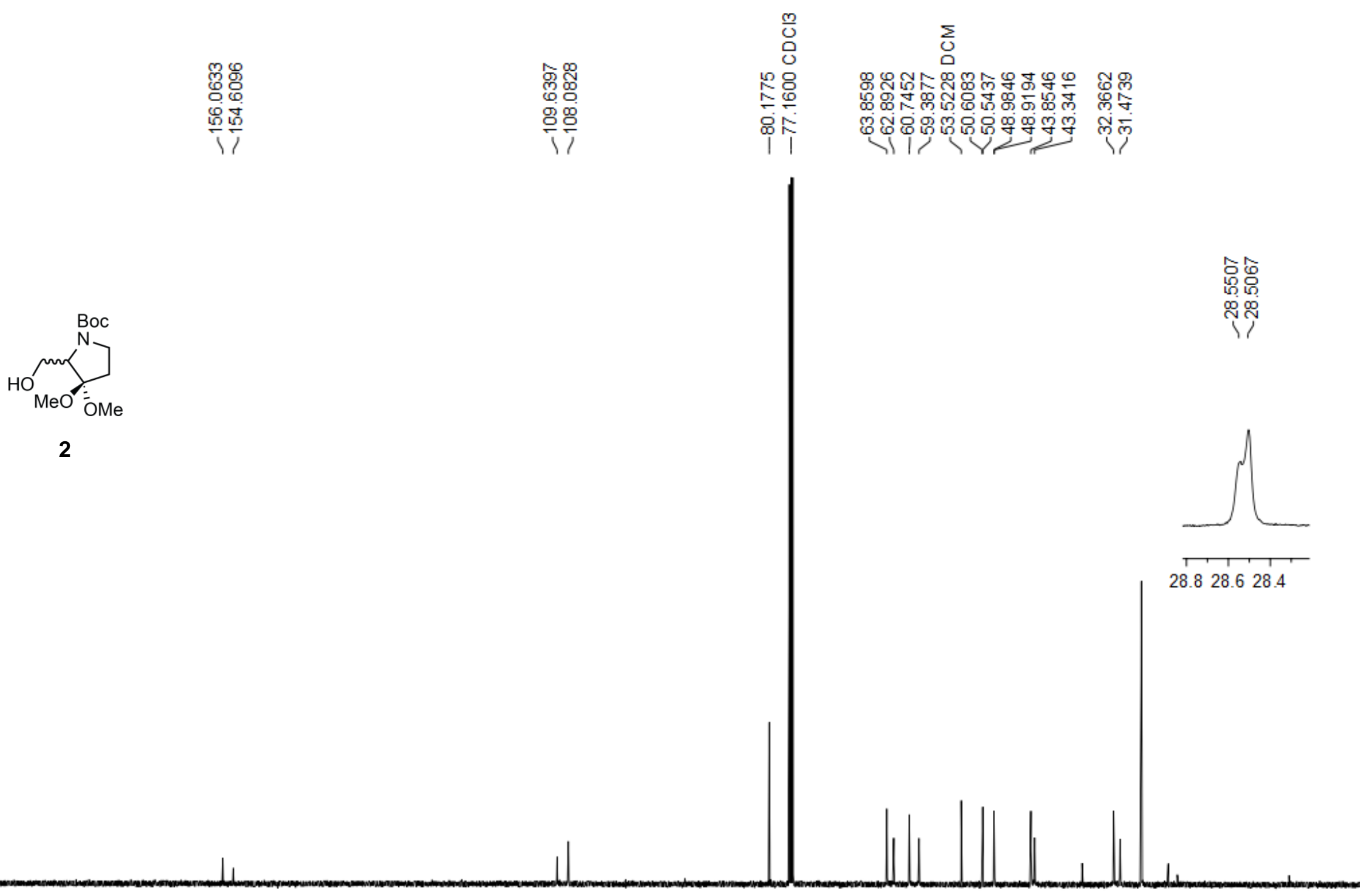

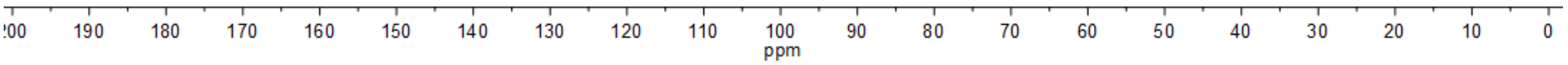


COSY NMR (500 MHz)

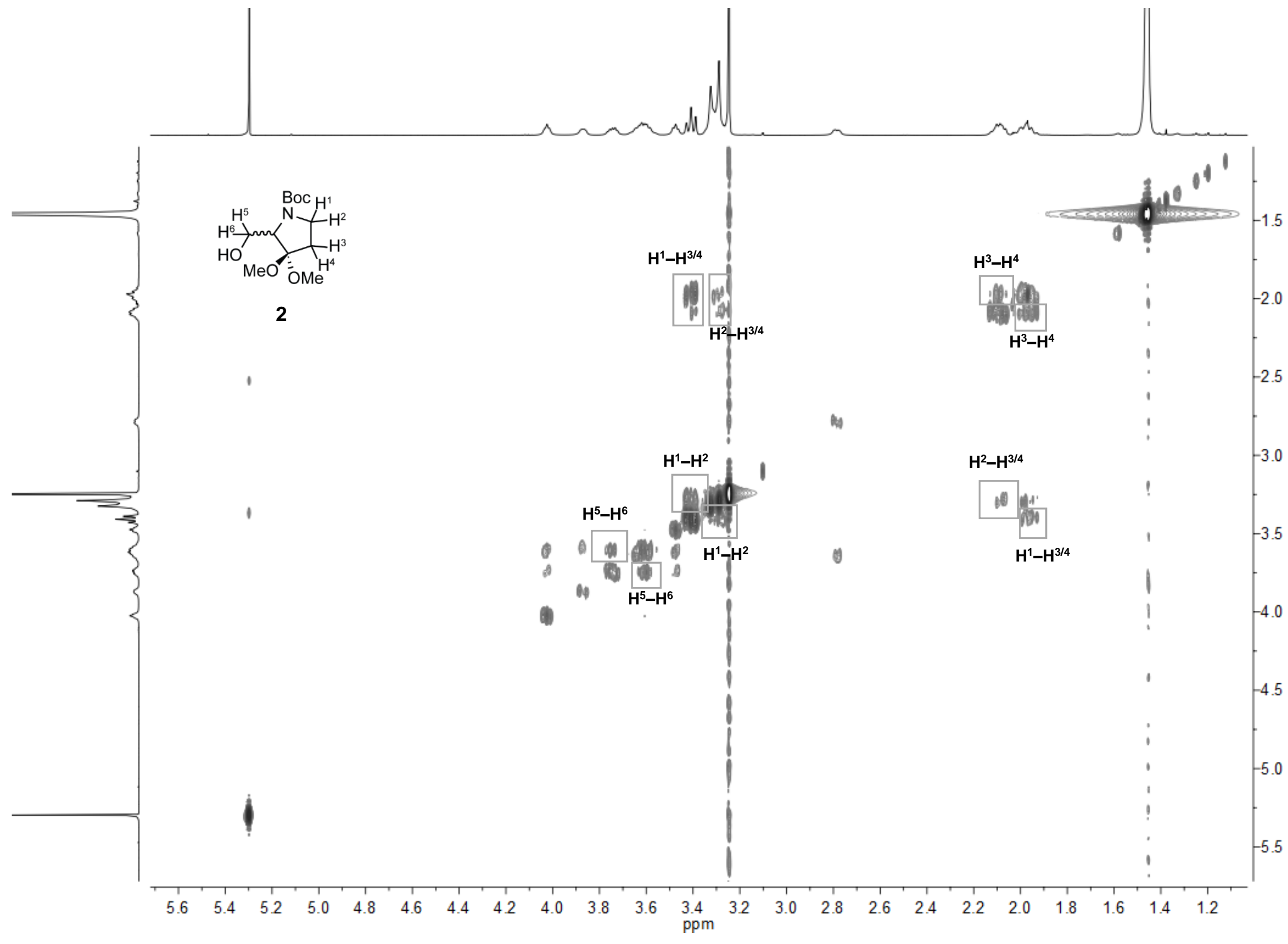

흘 
${ }^{1} \mathrm{H}$ NMR $(500 \mathrm{MHz})$

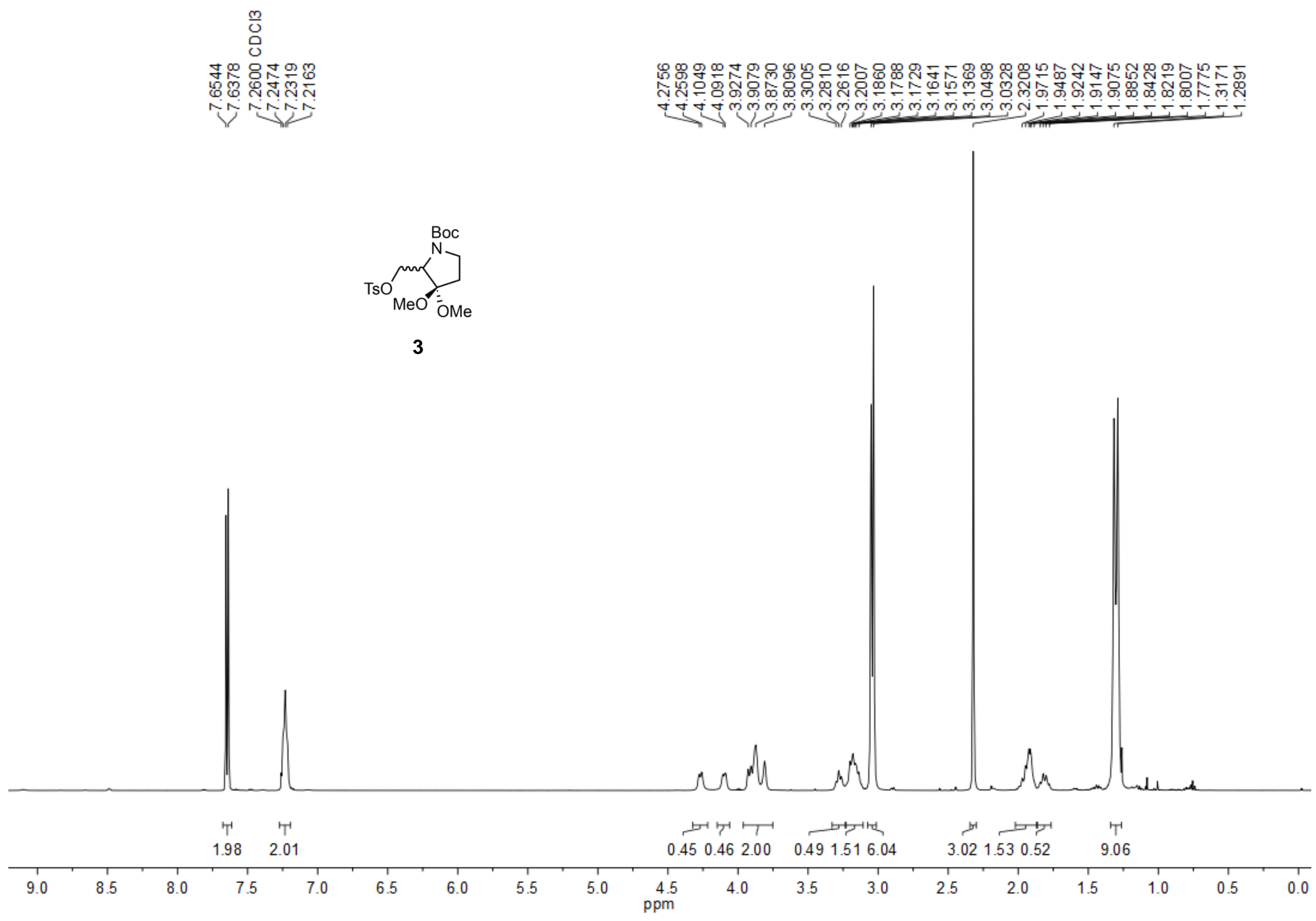

[25] 
${ }^{13} \mathrm{C}$ NMR $(500 \mathrm{MHz})$

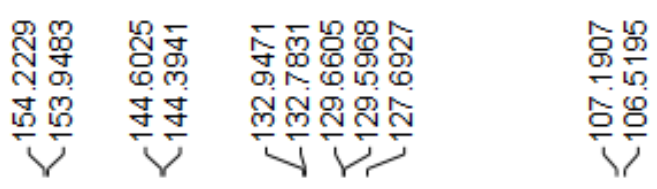
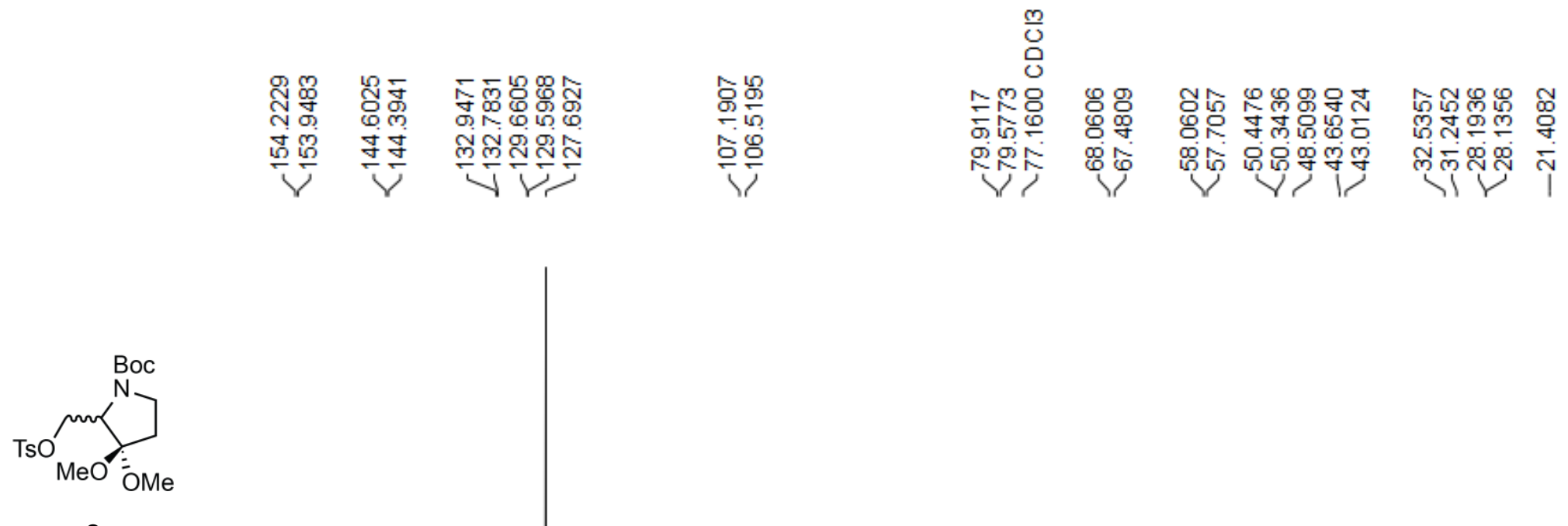

3

200 


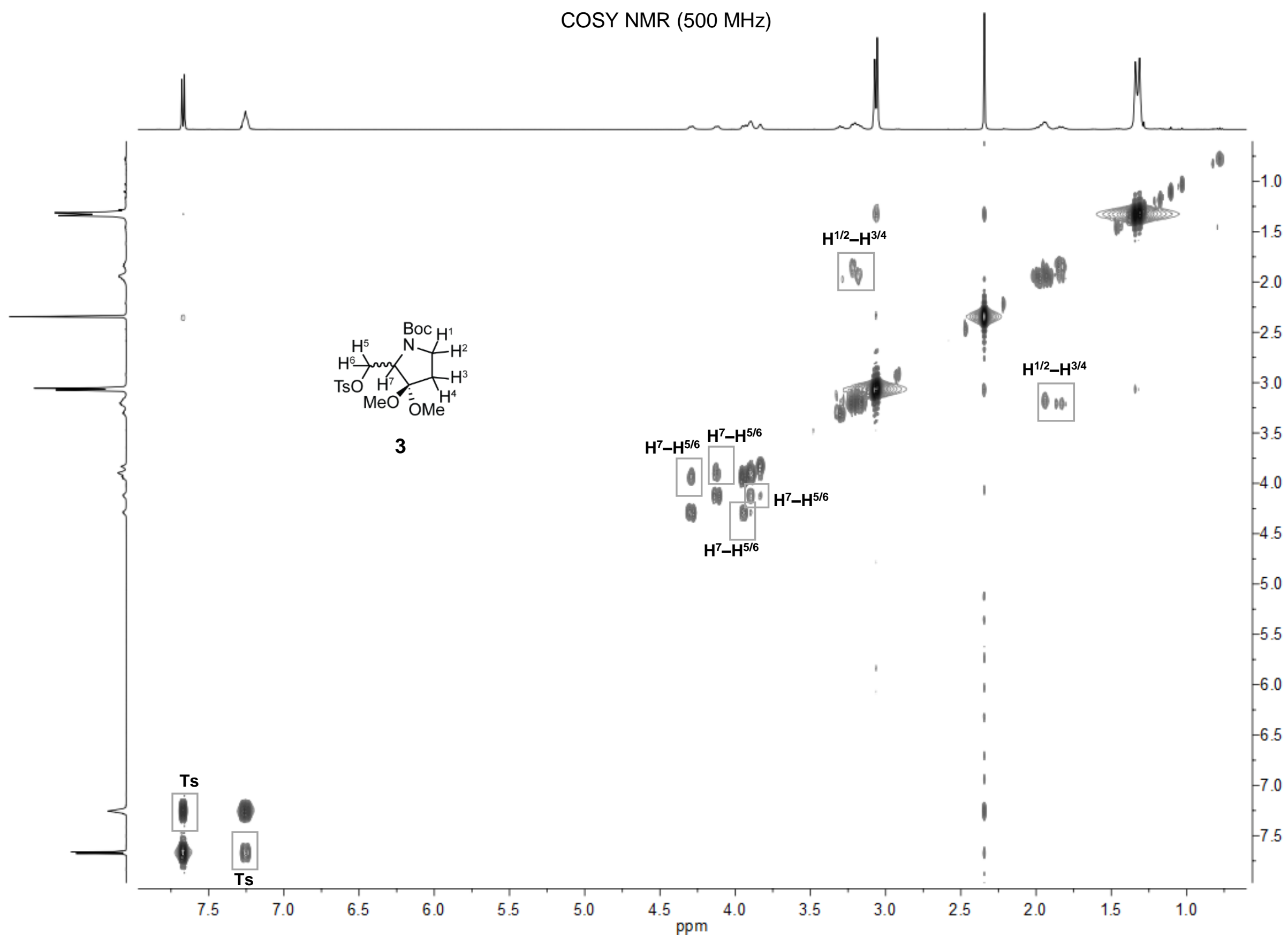


뮤음

ले ले ले

萬
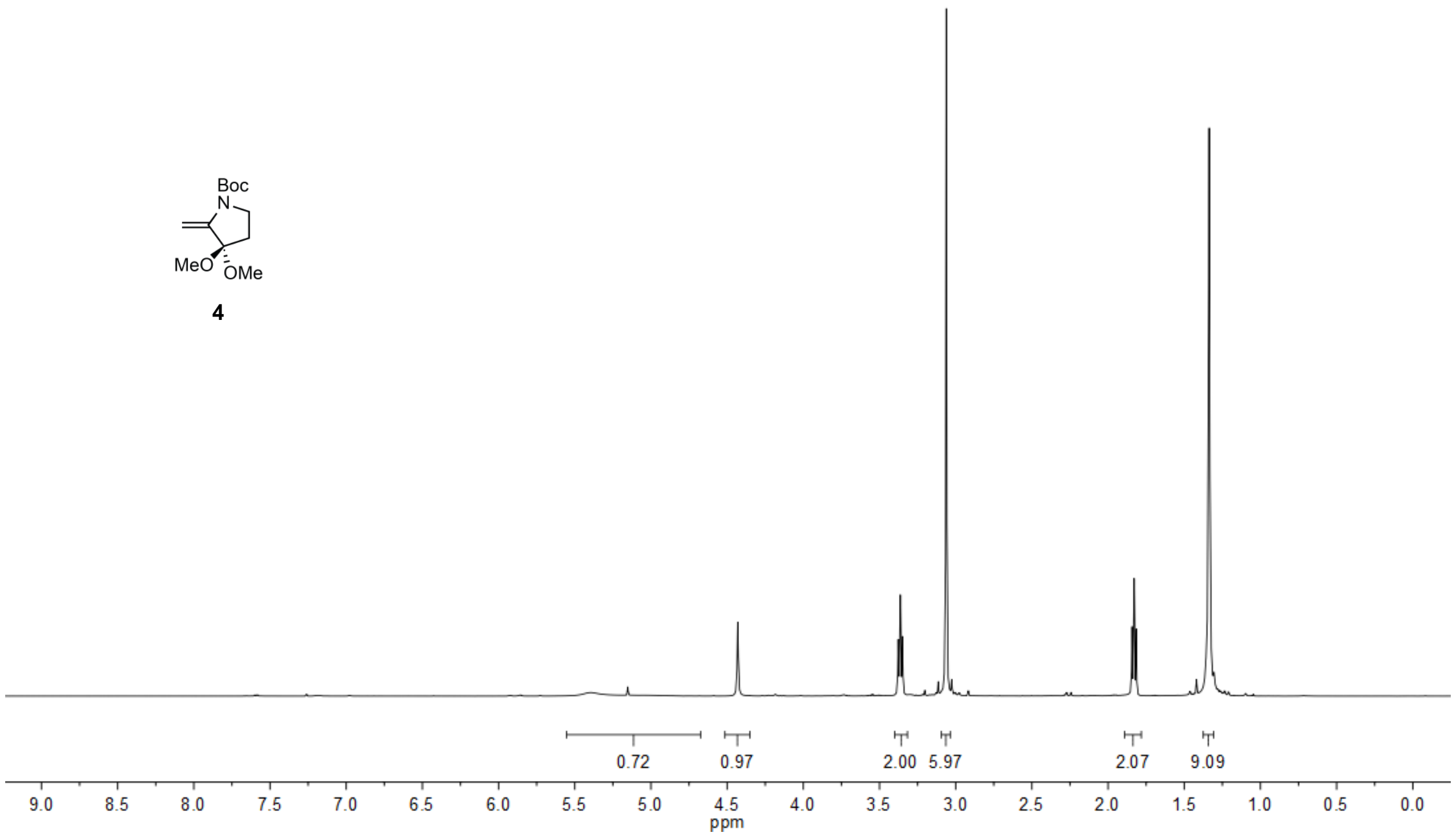


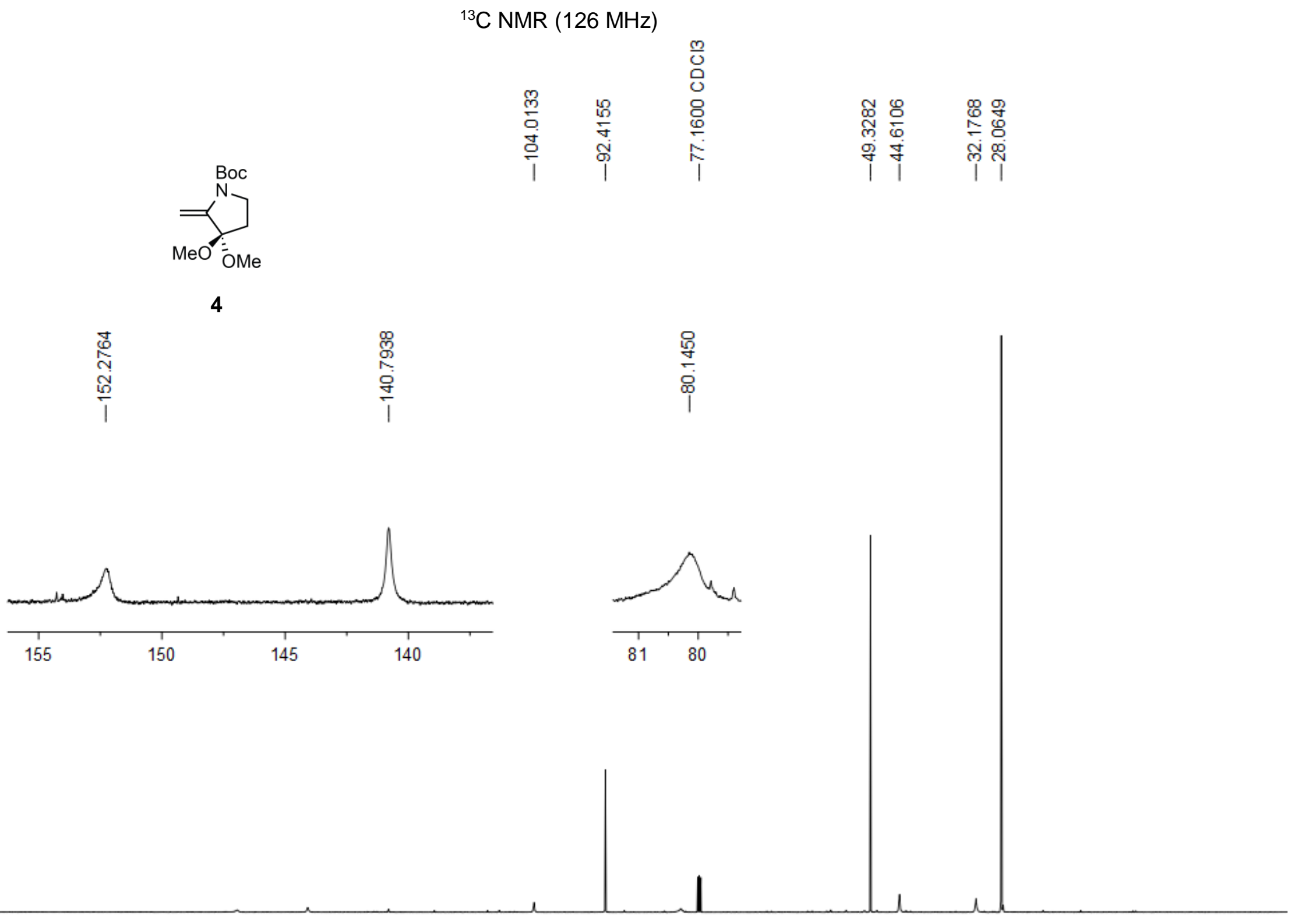




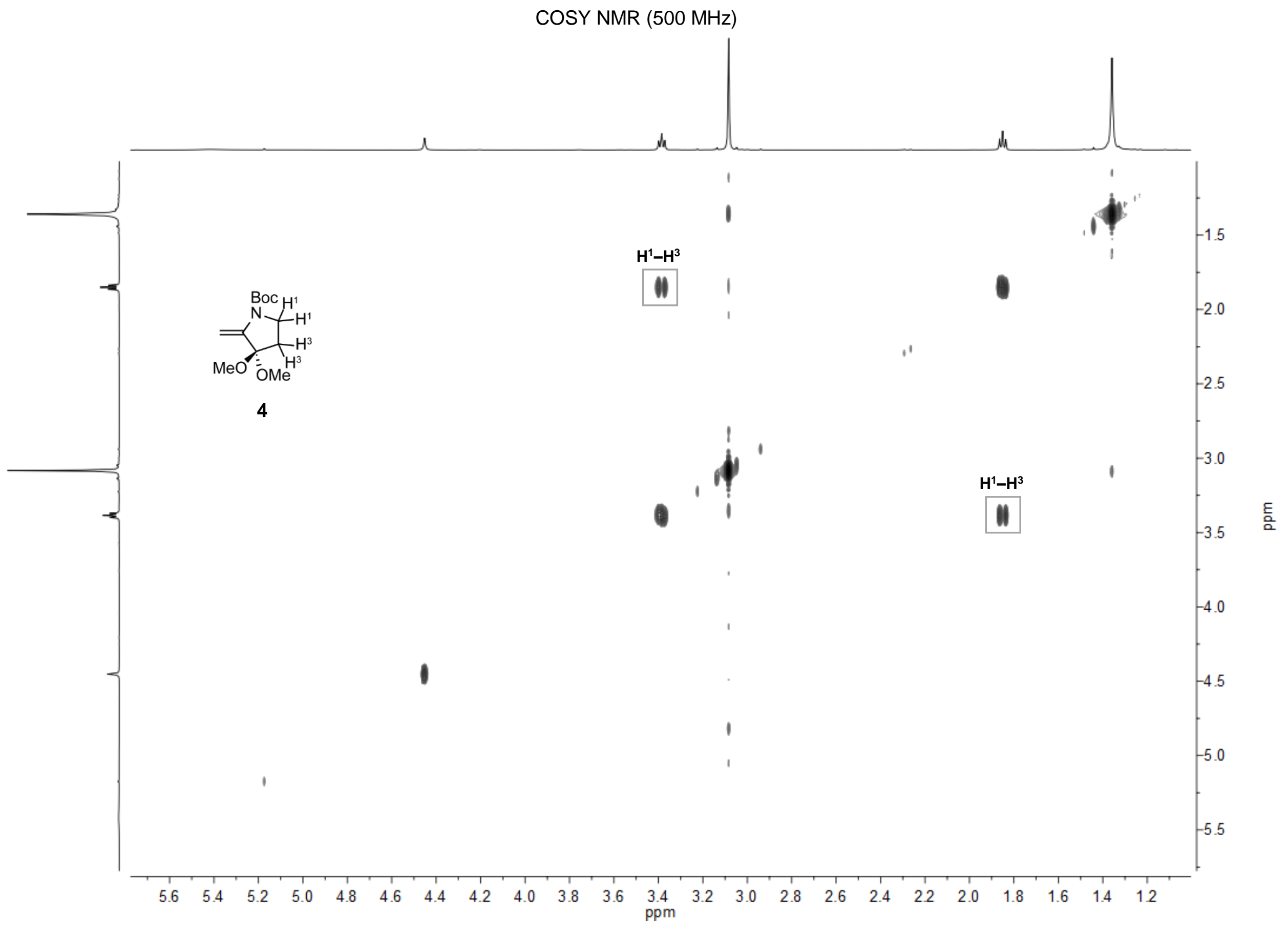

[30] 


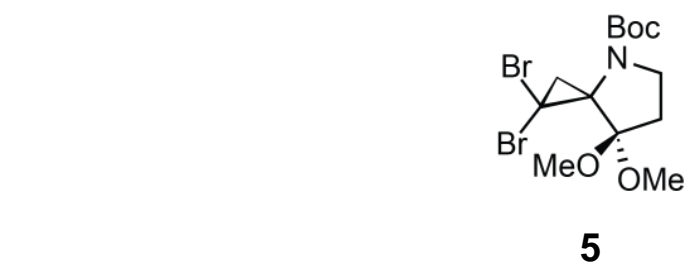

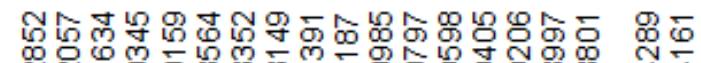
๙

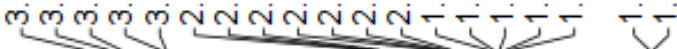

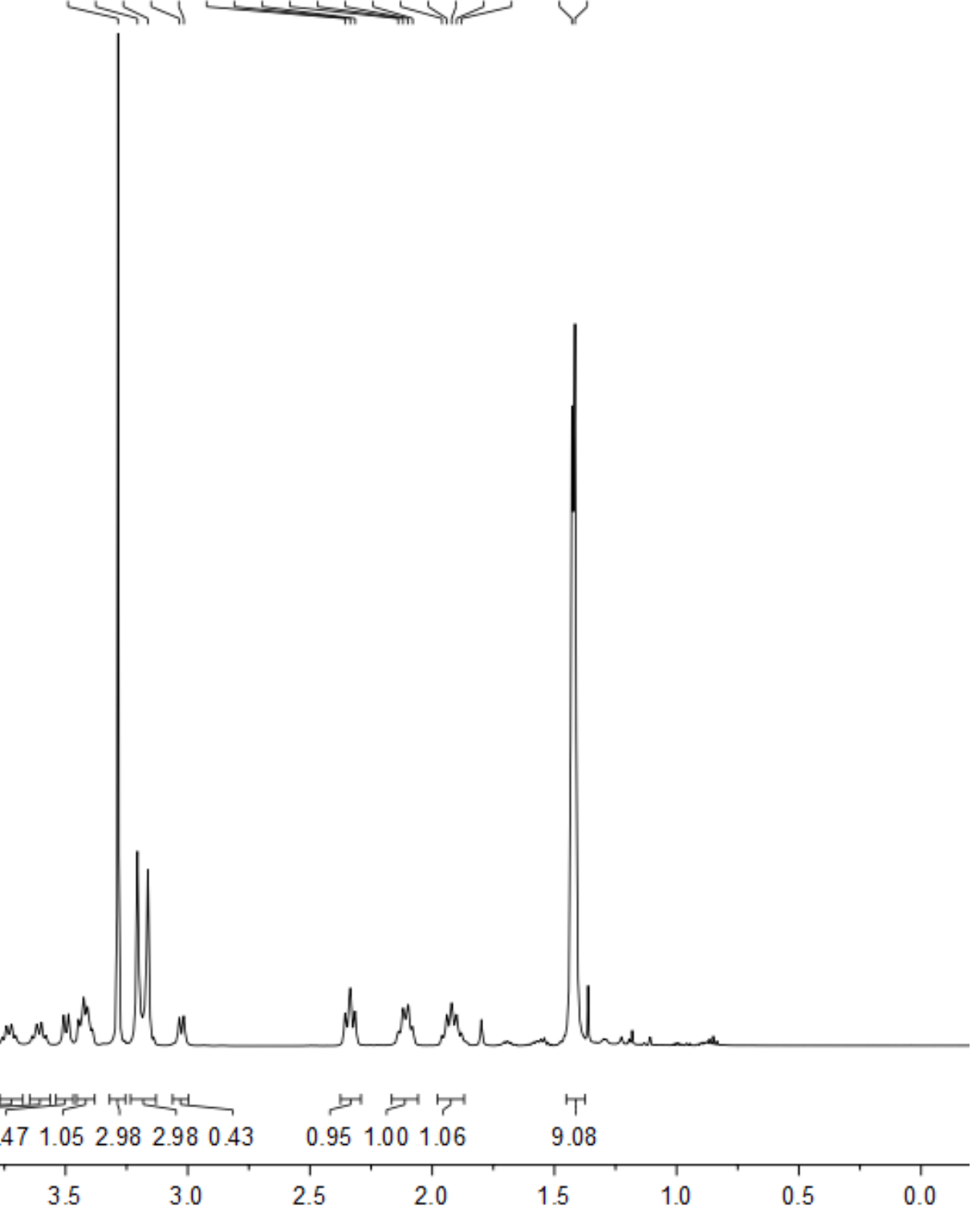


${ }^{13} \mathrm{C}$ NMR $(126 \mathrm{MHz})$

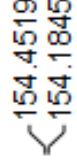

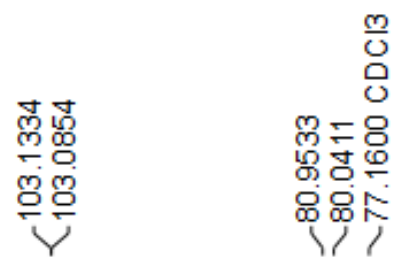

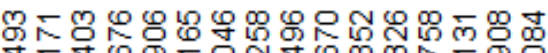

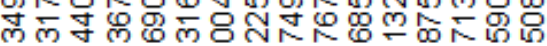

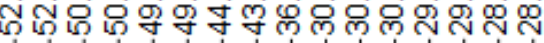

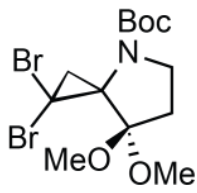

5 


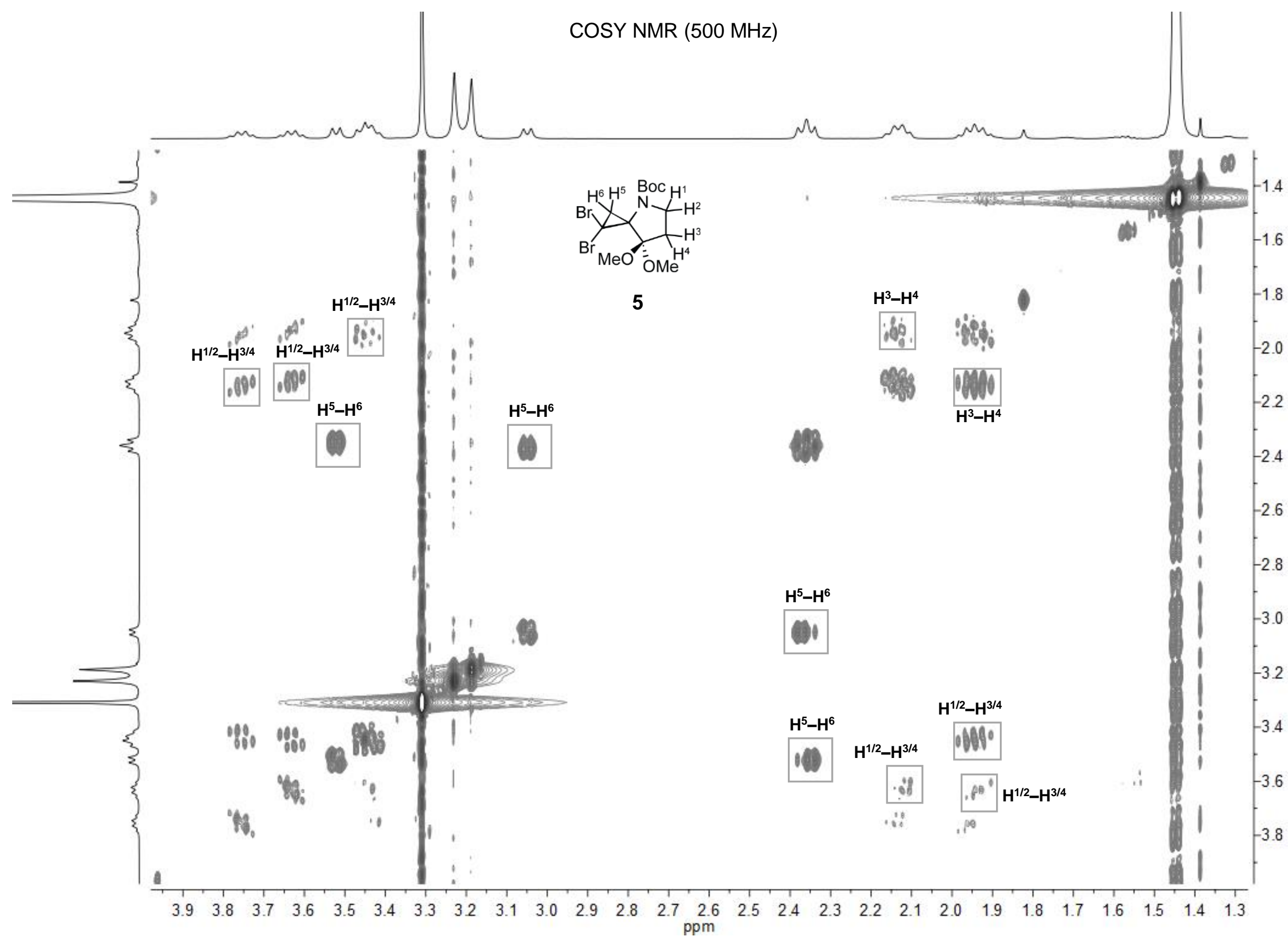


DEPT-135 NMR (500 MHz)
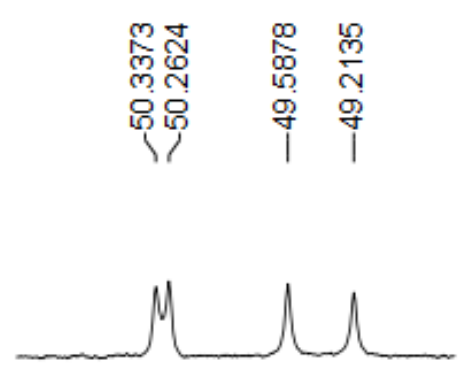

T' ' ' ' ' ' ' '

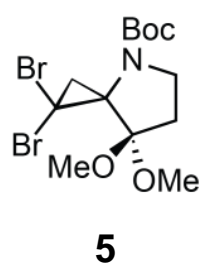

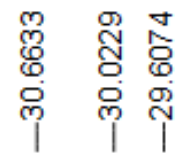

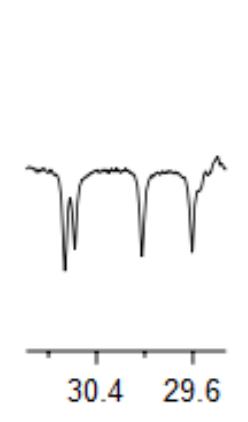

$30.4 \quad 29.6$
㖞员

ণั ֻั

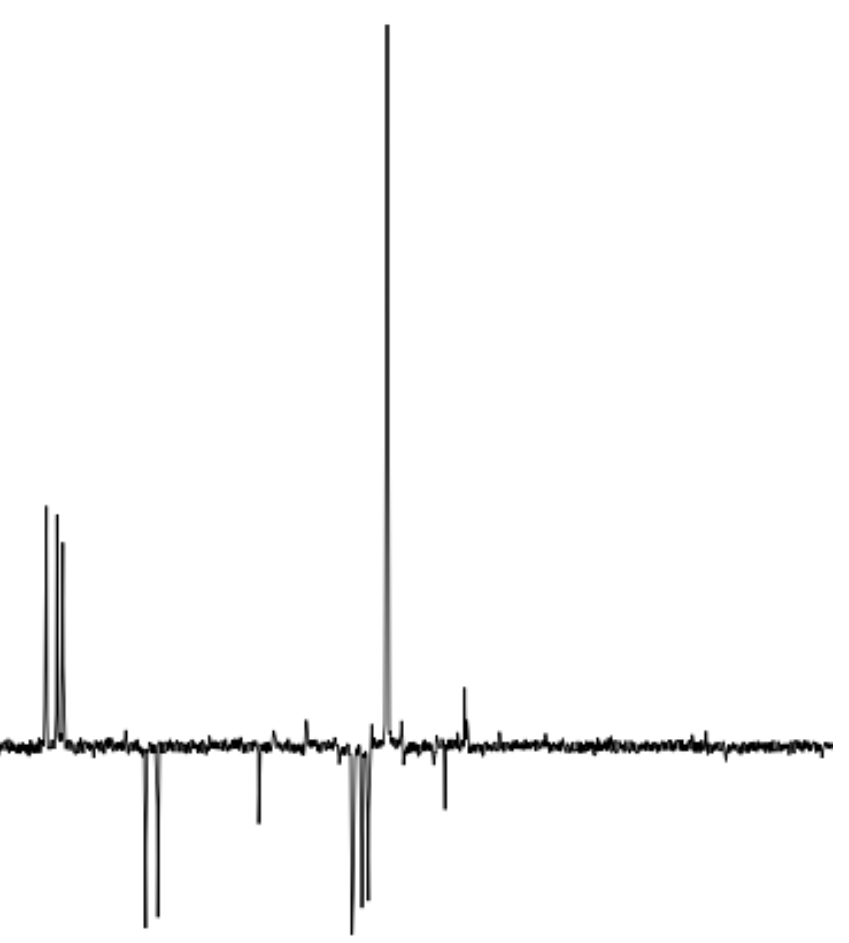


${ }^{1} \mathrm{H}$ NMR $(500 \mathrm{MHz})$
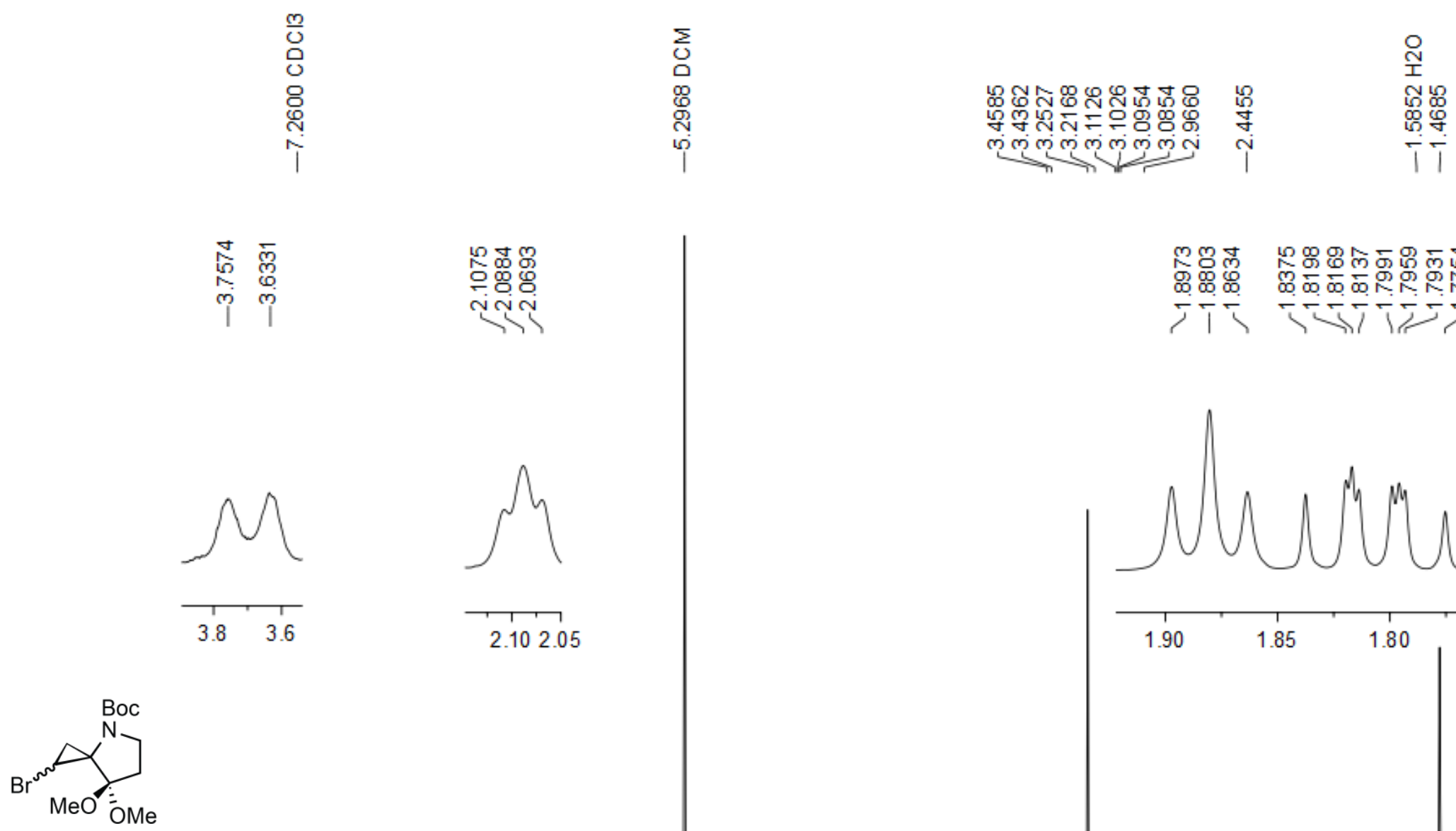

6

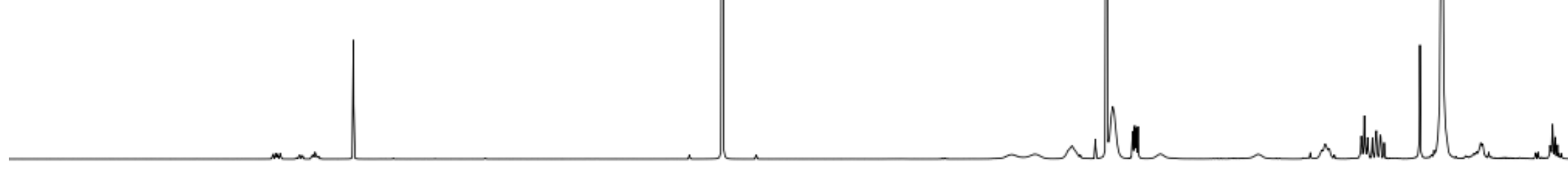

0.991 .103 .182 .871 .000 .520 .481 .041 .051 .089 .05

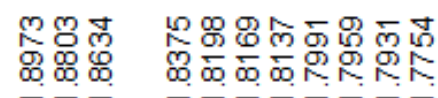

$j \frac{j}{\zeta}-\frac{\infty}{1} \div 5$

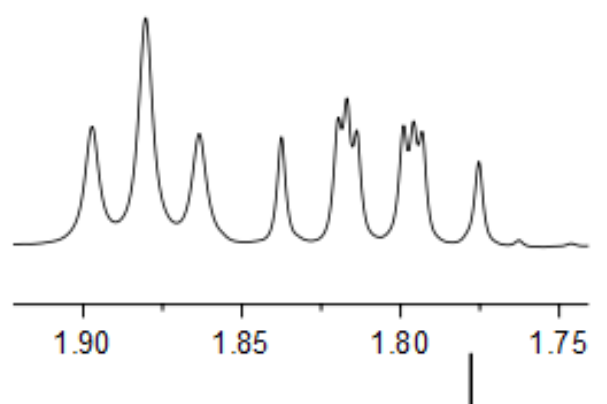




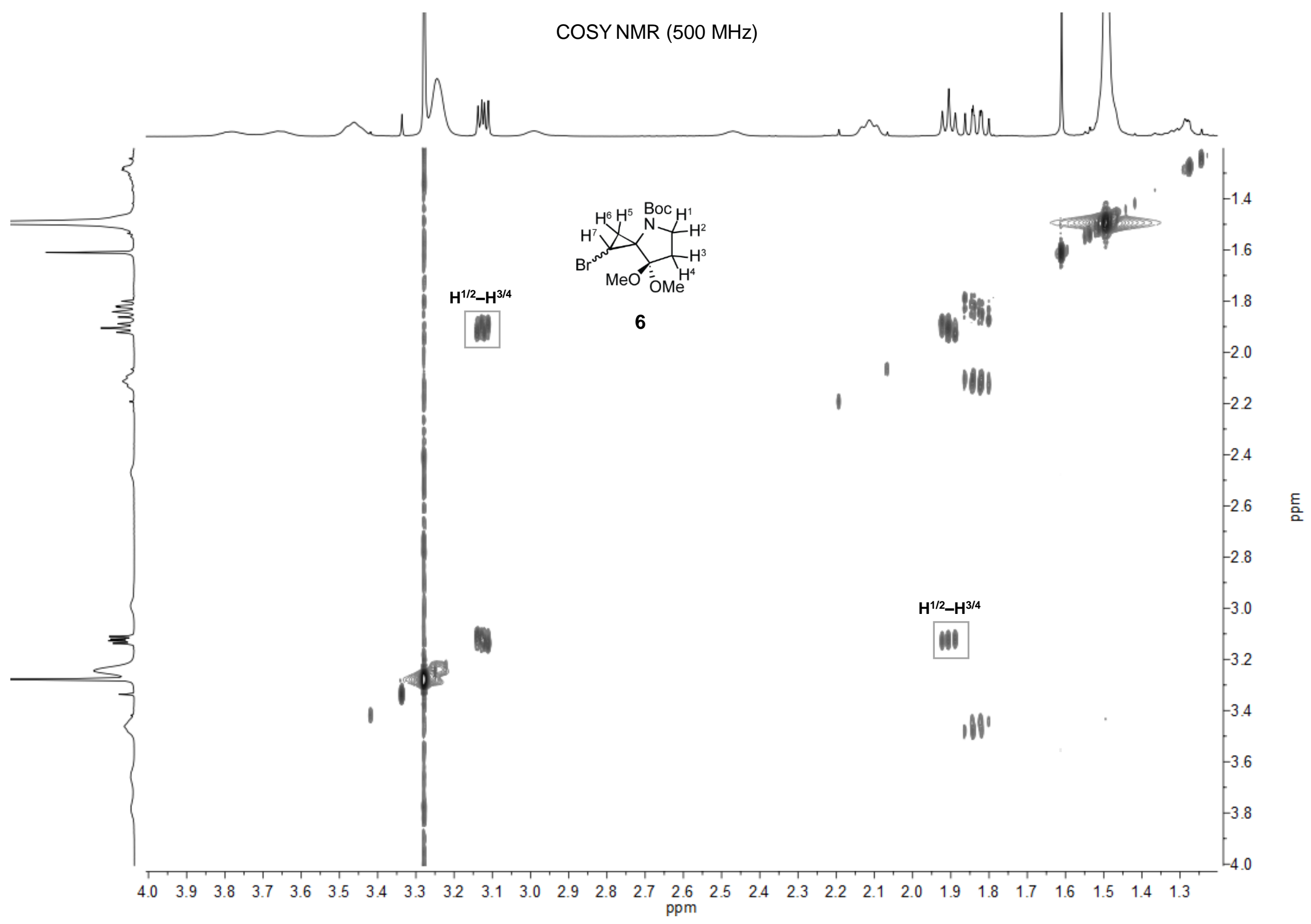


${ }^{1} \mathrm{H}$ NMR $(500 \mathrm{MHz})$

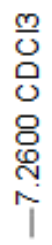

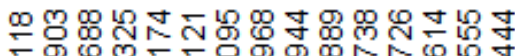

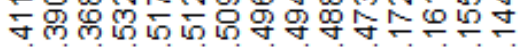

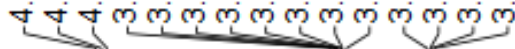

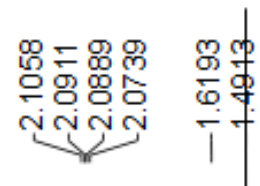

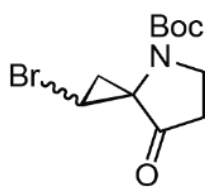

S5

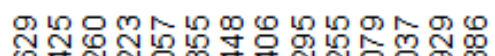

赵

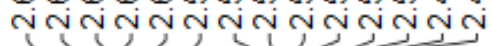

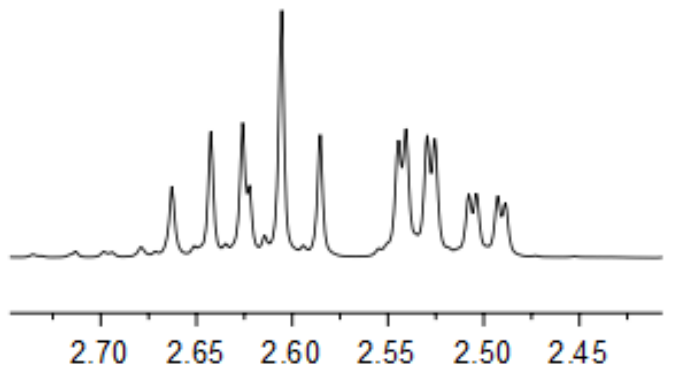

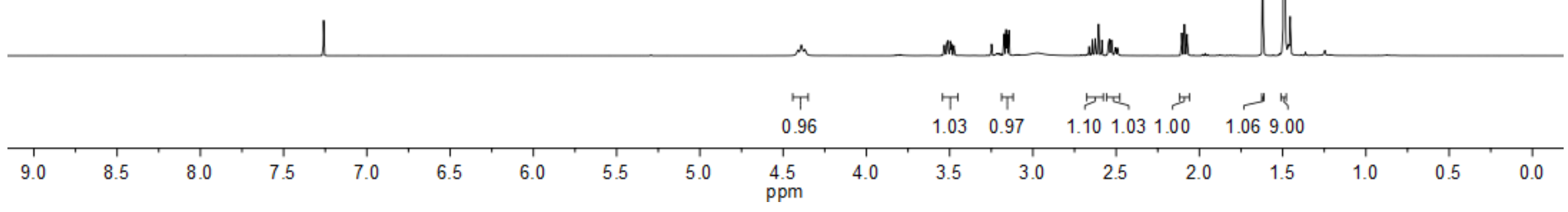

[37] 


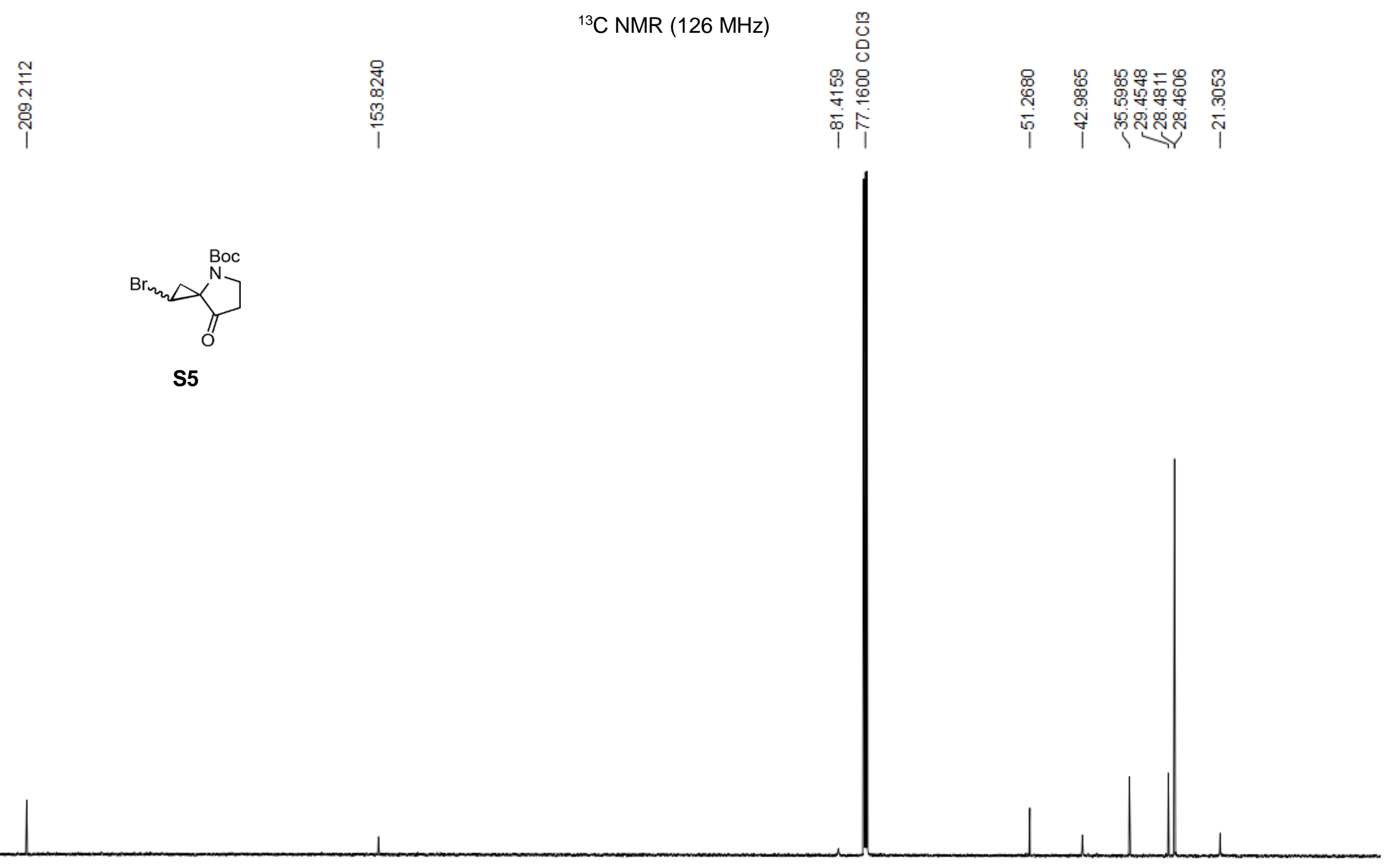

\begin{tabular}{|c|c|c|c|c|c|c|c|c|c|c|c|c|c|c|c|c|c|c|c|c|c|}
\hline 210 & 200 & 190 & $\begin{array}{c}1 \\
180\end{array}$ & $\begin{array}{c}1 \\
170\end{array}$ & 160 & $\begin{array}{c}1 \\
150\end{array}$ & 140 & $\begin{array}{c}1 \\
130\end{array}$ & 120 & $\begin{array}{c}1 \\
110\end{array}$ & 100 & 90 & 80 & 70 & 60 & 50 & 40 & 30 & 20 & $\begin{array}{c}1 \\
10\end{array}$ & $\begin{array}{l}1 \\
0\end{array}$ \\
\hline
\end{tabular}


COSY NMR $(500 \mathrm{MHz})$

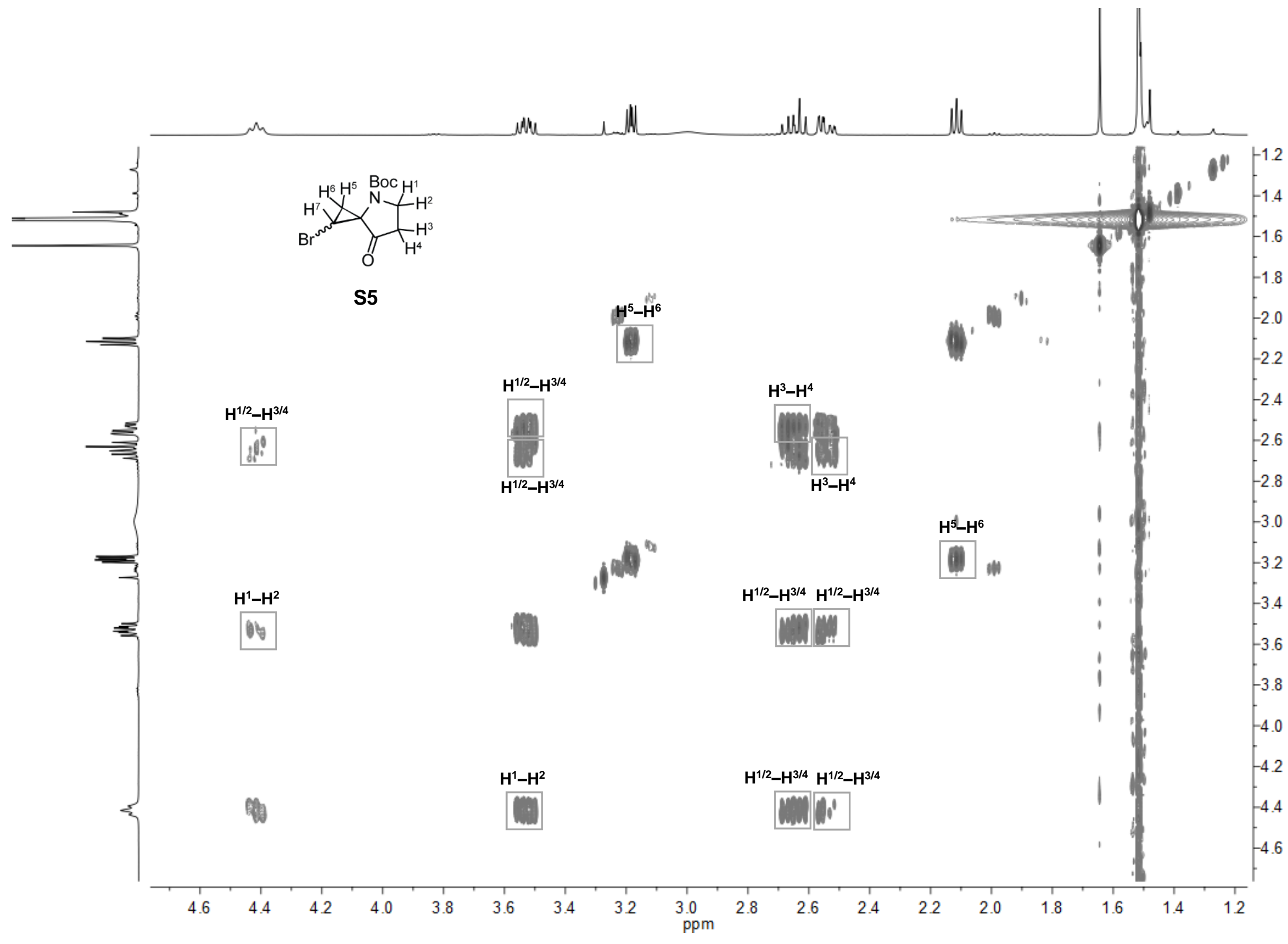

[39] 
${ }^{13} \mathrm{C}$ DEPT135 NMR (126 MHz)

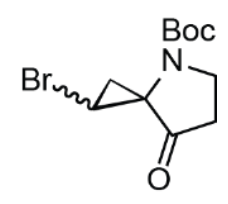

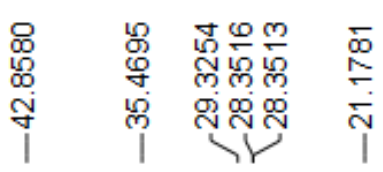

S5

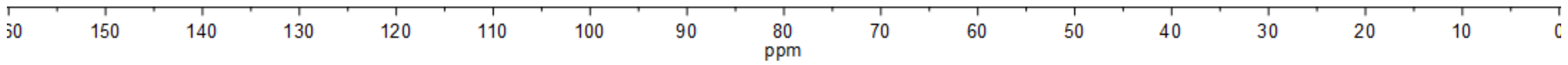


${ }^{1} \mathrm{H}$ NMR $(500 \mathrm{MHz})$

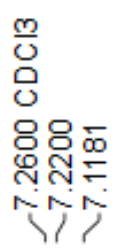

응우욤

ชัตำ

गलंखु

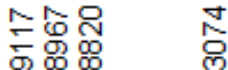

।

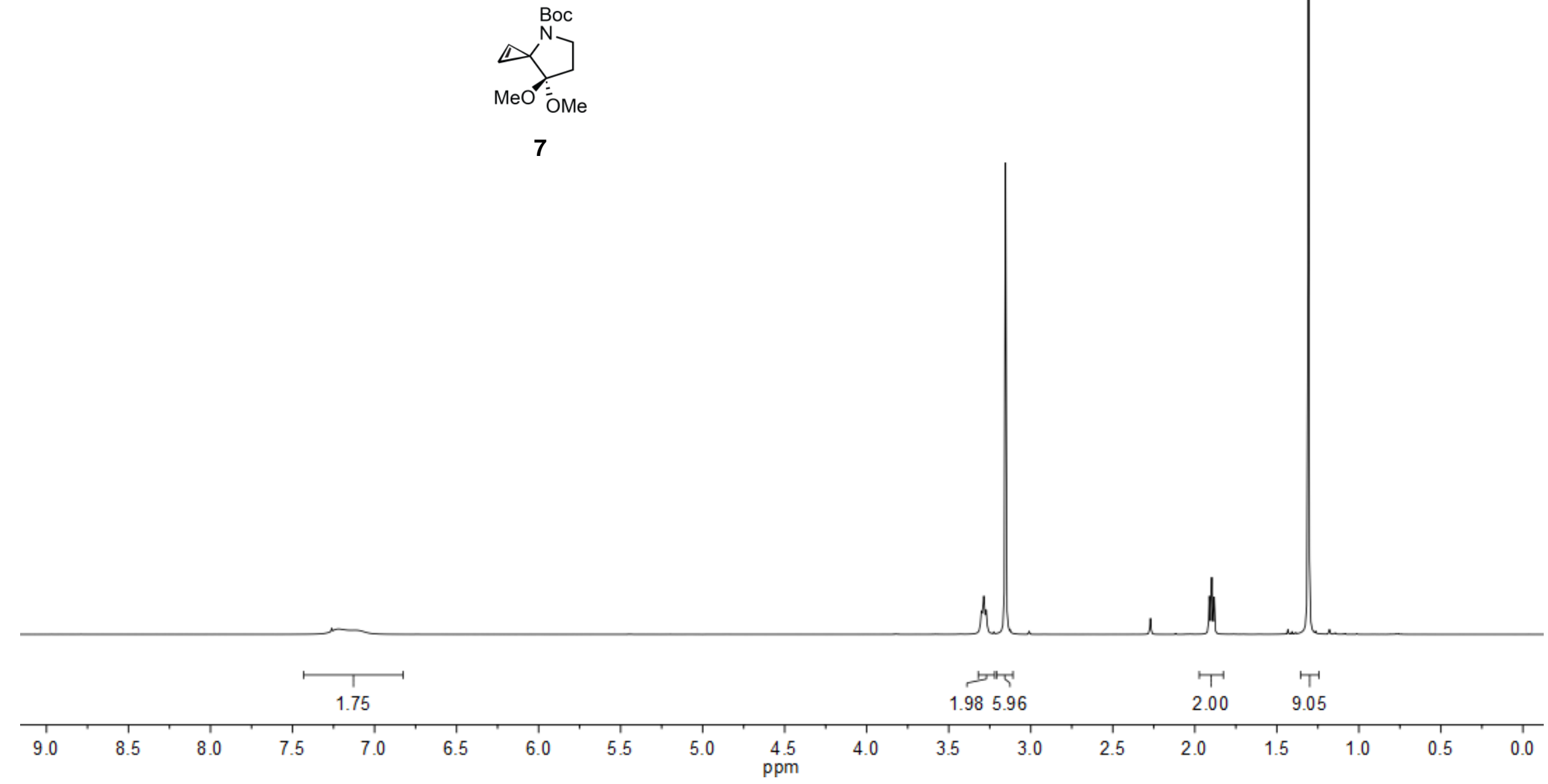

[41] 
COSY NMR $(500 \mathrm{MHz})$

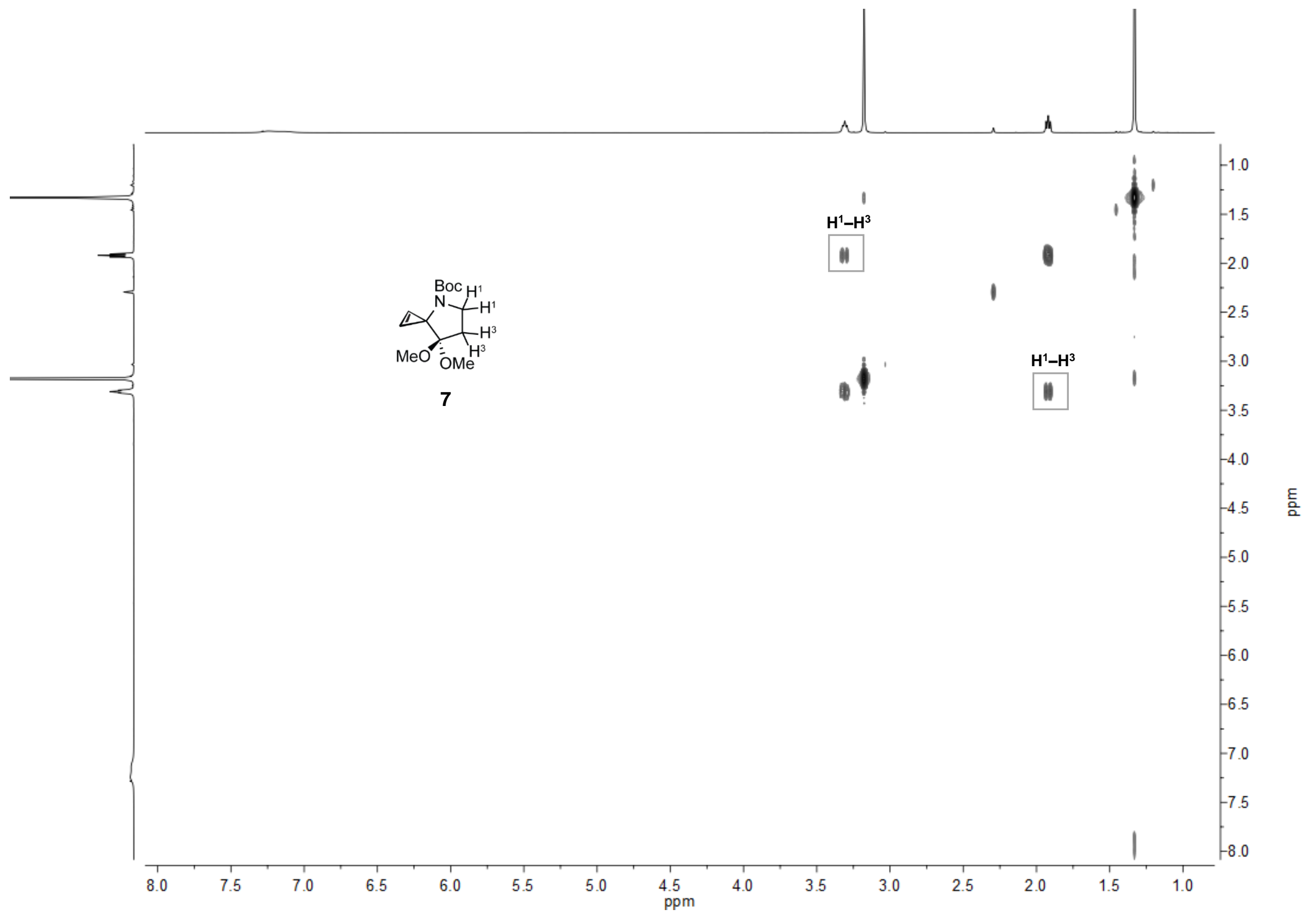

[43] 


\section{Scheme S4: Synthetic procedures for $8,9 a-b, 10 a-b$ and $11 a-b$}

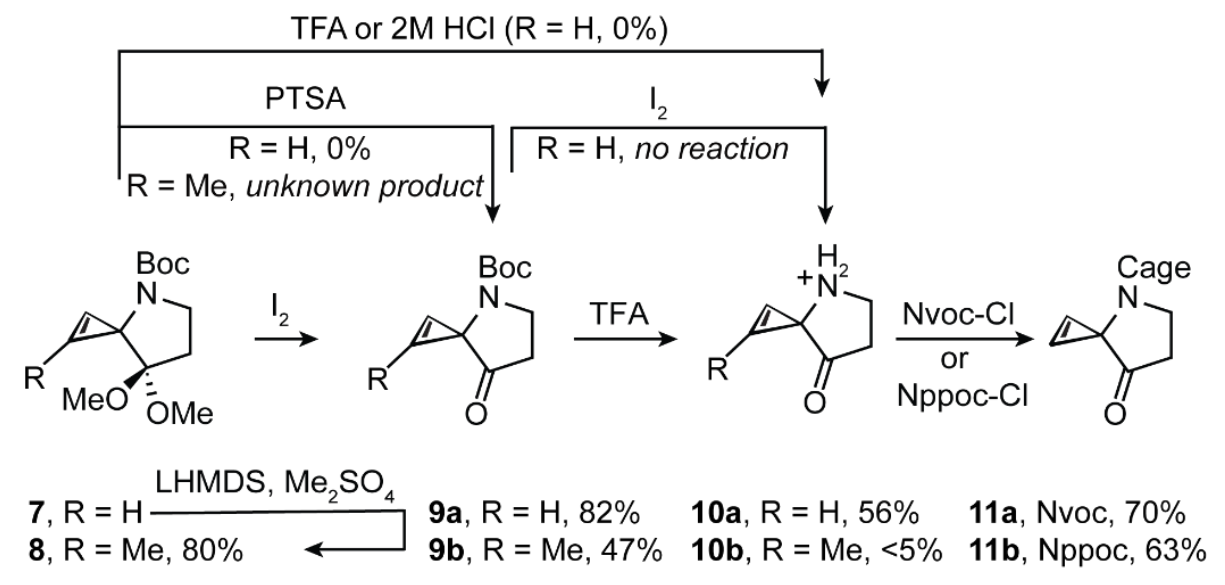

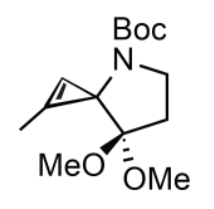

8

LHMDS methylation was based on prevously described methylation method for C3 disubtitutedcyclopropene molecules by us ${ }^{2}$ (for spiro cyclopropenes), and Kim and co-workers ${ }^{5}$ (for non-spiro cyclopropenes). To a solution of $7(80 \mathrm{mg}, 0.31 \mathrm{mmol}, 1.0 \mathrm{eq})$ in dry THF $(5 \mathrm{~mL})$ at $-40{ }^{\circ} \mathrm{C}$ to $-30{ }^{\circ} \mathrm{C}$ was added 1M LHMDS $(941 \mu \mathrm{L}, 0.94 \mathrm{mmol}, 3.0 \mathrm{eq})$ and $\mathrm{Me}_{2} \mathrm{SO}_{4}(89 \mu \mathrm{L} 118.7 \mathrm{mg}, 0.94 \mathrm{mmol}, 3.0$ eq) respectively. After stirring the reaction mixture at the same temperature for $3 \mathrm{~h}$ it was quenched with saturated $\mathrm{NH}_{4} \mathrm{Cl}$. The reaction mixture was concentrated and diluted with DCM and water. DCM layer was collected and the aqueous layer was further washed with DCM. The combined oragnic layer was dried over anhydrous $\mathrm{Na}_{2} \mathrm{SO}_{4}$, concentrated in vacuo, and purified by flash chromatography (15 g silica, 15\% EtOAc/hexanes(v/v)) to obtain 8 (67 mg, $80 \%$ ) as a pale-yellow oil. MS analysis of the purified sample always showed the presence of difficult to separate starting material. An analytical sample for compound characterization was prepared from column fraction(s) without any trace of starting material.

Another instance of this reaction starting from $227 \mathrm{mg}$ of 7 afforded $193 \mathrm{mf}$ of 8 (84.3\%). We also observed that starting the reaction with 1.5 eq of LHMDS and 1.1 eq of $\mathrm{Me}_{2} \mathrm{SO}_{4}$ required multiple additional quantities of LHMDS and $\mathrm{Me}_{2} \mathrm{SO}_{4}$ every 30 mins for the reaction to complete.

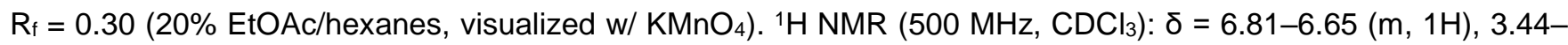
$3.33(\mathrm{~m}, 2 \mathrm{H}), 3.25(2 \times \mathrm{s}, 6 \mathrm{H}), 2.14(\mathrm{~s}, 3 \mathrm{H}), 2.03-1.92(\mathrm{~m}, 2 \mathrm{H}), 1.41(\mathrm{~s}, 9 \mathrm{H}) .{ }^{13} \mathrm{C} \mathrm{NMR}\left(101 \mathrm{MHz}, \mathrm{CDCl}_{3}\right): \delta=154.46,120.84$, 105.20, 103.16, 78.93, 50.37, 50.02, 49.96, 48.64, 32.14, 28.67, 11.12. COSY NMR (400 MHz, CDCl 3 , attached) was obtained under the same conditions. HRMS (ESI): Calcd for $\mathrm{C}_{14} \mathrm{H}_{23} \mathrm{NO}_{4} \mathrm{Na}^{+}[\mathrm{M}+\mathrm{Na}]^{+}:$292.1519, found: 292.1517.

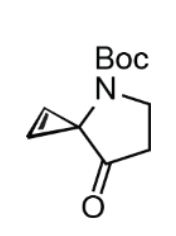

$9 a$

$\mathrm{I}_{2}$ mediated conversion of ketal to ketone under neutral conditions was adapted from prevously described method for non-cyclopropene molecules ${ }^{6}$. To an ice-cold solution of 7 (100 mg, 0.078 $\mathrm{mmol}, 1 \mathrm{eq})$ in acetone $(10 \mathrm{~mL})$ was added catalytic amount of $\mathrm{I}_{2}(4.97 \mathrm{mg}, 0.02 \mathrm{mmol}, 0.05 \mathrm{eq})$. The dark orange reaction mixture showed complete consumtion of starting material within 14 mins. The reaction mixture was quenched with freshly prepared $5 \%$ aqueous $\mathrm{Na}_{2} \mathrm{~S}_{2} \mathrm{O}_{3}$ and stirred at the same temperature for 5 mins (the brown colour dissparead). The reaction mixture was then concentrated under reduced pressure $\left(\mathrm{t}=22^{\circ} \mathrm{C}\right)$ and diluted with DCM and. DCM layer was collected and the aqueous layer was further washed with DCM. The combined oragnic layer was washed with brine, dried over anhydrous $\mathrm{Na}_{2} \mathrm{SO}_{4}$, concentrated in 
vacuo. Although we performed flash chromatography (21 g silica, 25-30\% EtOAc/hexanes(v/v)) to obtain 9a (68 mg, $82 \%)$ as a light-yellow semi-solid, it was sufficiently (no other spots on TLC w/ UV or $\mathrm{KMnO}_{4}$ stain) pure even without the column.

Another instance of this reaction starting from $20 \mathrm{mg}$ of 8 and 0.1 eq of $\mathrm{I}_{2}$ at $\mathrm{rt}$ afforded $12 \mathrm{mg} 9 \mathrm{a} \mathrm{(75 \% ).}$

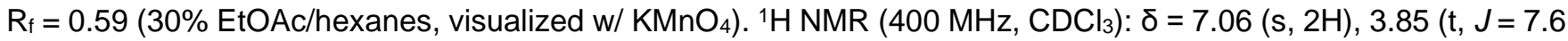
$\mathrm{Hz}, 2 \mathrm{H}), 2.61$ (t, $J=7.7 \mathrm{~Hz}, 2 \mathrm{H}), 1.43(\mathrm{~s}, 9 \mathrm{H}) .{ }^{13} \mathrm{C} \mathrm{NMR}\left(101 \mathrm{MHz}, \mathrm{CDCl}_{3}\right): \delta=214.22,154.25,108.33,80.38,48.85,40.77$, 35.10, 28.62. COSY NMR (400 MHz, $\mathrm{CDCl}_{3}$, attached) was obtained under the same conditions. HRMS (ESI): Calcd for $\mathrm{C}_{11} \mathrm{H}_{16} \mathrm{NO}_{3}+[\mathrm{M}+\mathrm{H}]^{+}: 210.1125$, found: 210.1125 .

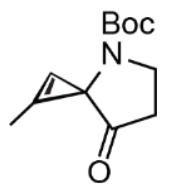

$9 b$

To an ice-cold solution of 8 (193 $\mathrm{mg}, 0.717 \mathrm{mmol}, 1 \mathrm{eq})$ in acetone $(35 \mathrm{~mL})$ was added catalytic amount of $\mathrm{I}_{2}(18.2 \mathrm{mg}, 0.072 \mathrm{mmol}, 0.1 \mathrm{eq})$. The dark orange reaction mixture showed that most of the starting material was consumed within 5 minutes. TLC analysis agter carrying the reaction for additional 30 mins did not show any appreciable difference. The reaction mixture was then concentrated under reduced pressure $\left(t=21^{\circ} \mathrm{C}\right)$ and diluted with $\mathrm{DCM}$ and $5 \%$ aqueous $\mathrm{Na}_{2} \mathrm{~S}_{2} \mathrm{O}_{3}$. DCM layer was collected and the aqueous layer was further washed with DCM. The combined oragnic layer was washed with brine, dried over anhydrous $\mathrm{Na}_{2} \mathrm{SO}_{4}$, concentrated in vacuo, and purified by flash chromatography (22 g silica, 20-30\% EtOAc/hexanes(v/v)) to obtain an inseparable mixture of 67:33 9b $(70 \mathrm{mg}, 46.7 \%)$ and 9 a $(30 \mathrm{mg}$ ) respectively. We found this molecule to slowly decompose and produce a baseline spot on TLC upon concentration, therefore, it was used immediately. $\mathrm{R}_{\mathrm{f}}=0.59\left(30 \% \mathrm{EtOAc} / \mathrm{hexanes}\right.$, visualized $\left.\mathrm{w} / \mathrm{KMnO}_{4}\right) .{ }^{1} \mathrm{H} \mathrm{NMR}(700$ $\left.\mathrm{MHz}, \mathrm{CDCl}_{3}\right): \delta=7.02(\mathrm{~s}, 1 \mathrm{H}), 6.47(\mathrm{~s}, 0.65 \mathrm{H}), 3.82(\mathrm{q}, J=9.6,7.7 \mathrm{~Hz}, 2 \mathrm{H}), 3.73(\mathrm{q}, J=9.6 \mathrm{~Hz}, 0.86 \mathrm{H}), 2.54-2.57(\mathrm{~m}$, $2.82 \mathrm{H}), 2.10(\mathrm{~s}, 2.62 \mathrm{H}), 1.38(\mathrm{~s}, 12 \mathrm{H}) .{ }^{13} \mathrm{C} \mathrm{NMR}\left(176 \mathrm{MHz}, \mathrm{CDCl}_{3}\right): \delta=214.90,214.15,168.59,154.13,108.20,106.67$, 80.26, 79.87, 53.51, 52.09, 48.73, 40.70, 34.97, 28.50, 10.45. HRMS could not be obtained due to continuous decomposition of 9b. $\mathrm{MS}(\mathrm{ESI})$ : Calcd for $\mathrm{C}_{12} \mathrm{H}_{18} \mathrm{NO}_{3}[\mathrm{M}+\mathrm{H}]^{+}$: 224.1, found: 224.1,168.0 [M-C $\left.\left(\mathrm{CH}_{3}\right)_{3}+2 \mathrm{H}\right]^{+}, 124.1[\mathrm{M}-$ $\mathrm{Boc}+2 \mathrm{H}]^{+}$.

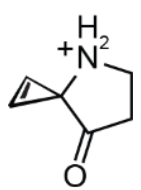

$10 a$

To an ice-cold solution of $9 \mathrm{a}(67 \mathrm{mg}, 0.32 \mathrm{mmol}, 1.0 \mathrm{eq})$ in DCM $(10 \mathrm{~mL})$ was dropwise added TFA $(2.0 \mathrm{~mL})$. The reaction was allowed to warm over $2 \mathrm{~h}$ and stopped based on MS analysis. The reaction mixture was concentrated, resuspended in water $(3 \mathrm{~mL})$, purified using analytical column on HPLC $\left(R_{t}=4.20\right.$ min, $0-100 \% \mathrm{MeOH}+0.1 \%$ TFA over 20 minutes), and concentrated (@ $21^{\circ} \mathrm{C}$ ) to obtain 10a (40 mg, 56\%) as a TFA salt. ${ }^{1} \mathrm{H}$ NMR (400 MHz, $\left.\mathrm{CD}_{3} \mathrm{OD}\right): \delta=7.53(\mathrm{~s}, 2 \mathrm{H}), 3.77$ (t, $\mathrm{J}=8.0 \mathrm{~Hz}$, 2H), 2.80 (t, $J=8.0 \mathrm{~Hz}, 2 \mathrm{H}) .{ }^{13} \mathrm{C}$ NMR (101 MHz, CD ${ }_{3} \mathrm{OD}$ ): $\delta=208.33,106.66,40.54,34.73$. COSY $\operatorname{NMR}\left(400 \mathrm{MHz}, \mathrm{CDCl}_{3}\right.$, attached) was obtained under the same conditions. HRMS (ESI): Calcd for $\mathrm{C}_{6} \mathrm{H}_{8} \mathrm{NO}^{+}\left[\mathrm{M}^{+}: 110.0600\right.$, found: 110.0603 .

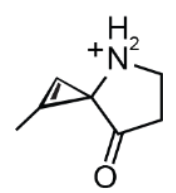

10b

To an ice-cold solution of 67:33 mixture of $9 \mathbf{a}$ and $9 \mathbf{b}$ (total $100 \mathrm{mg}$ ) in DCM (10 mL) was dropwise added TFA $(2.0 \mathrm{~mL})$. The reaction was allowed to warm over $2 \mathrm{~h}$ and stopped based on MS analysis. The reaction mixture was concentrated, resuspended in $55 \% \mathrm{MeCN} /$ water $(3 \mathrm{~mL})$, and subjected to HPLC purification ( $\mathrm{R}_{\mathrm{t}}=4.4 \mathrm{~min}, 100 \% \mathrm{H}_{2} \mathrm{O}+0.1 \%$ TFA over 10 minutes). MS analysis of peak(s) at 4.4 min provided the target mass, however, our multiple attempts to purify $10 \mathrm{~b}$ did not succeed. Analysis of the HPLC trace suggested product to be present in $<10 \%$ amount. MS (ESI): Calcd for $\mathrm{C}_{7} \mathrm{H}_{10} \mathrm{NO}^{+}[\mathrm{M}]^{+}:$124.1, found: 124.1 . 
General method for synthesis of 11a-b: To an ice-cold solution of $\mathbf{9 a}$ (1.0 eq) in DCM (8 mL) was dropwise added TFA (2.0 $\mathrm{mL}$ ). The reaction was allowed to warm over $2 \mathrm{~h}$ and stopped upon complete consumption of $9 \mathrm{a}$. The reaction mixture was concentrated, resuspended in MeCN-water $(2: 1,15 \mathrm{~mL})$ and cooled down to $0{ }^{\circ} \mathrm{C}$. Chloroformate reagent $(\mathrm{Nvoc}-\mathrm{Cl}$ or NPPOC-Cl, 2.0 eq) and solid $\mathrm{NaHCO}_{3}$ (final $\mathrm{pH}$ of the reaction mixture $~ 8.5$ ) were added and the reaction mixture was allowed to warm to rt overnight. The reaction mixture was concentrated and diluted with DCM. DCM layer was collected and the aqueous layer was further washed with DCM. The combined oragnic layer was washed with brine, dried over anhydrous $\mathrm{Na}_{2} \mathrm{SO}_{4}$, concentrated in vacuo, and purified by flash chromatography (silica, $20-25 \%$ EtOAc/hexanes $(\mathrm{v} / \mathrm{v})$ ) to obtain 11a-b.

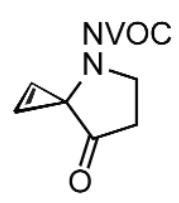

$11 a$

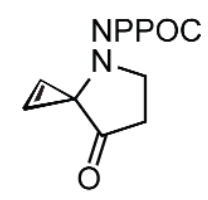

11b Light-yellow oil. $\mathrm{R}_{\mathrm{f}}=0.21\left(30 \%\right.$ EtOAc/hexanes, visualized w/ UV). ${ }^{1} \mathrm{H}$ NMR $\left(400 \mathrm{MHz}, \mathrm{CDCl}_{3}\right): \delta=$ $7.65(\mathrm{~s}, 1 \mathrm{H}), 7.07(\mathrm{~s}, 2 \mathrm{H}), 6.95(\mathrm{~s}, 1 \mathrm{H}), 5.43(\mathrm{~s}, 2 \mathrm{H}), 3.96-3.96(\mathrm{~m}, 8 \mathrm{H}), 2.64(\mathrm{t}, J=7.7 \mathrm{~Hz}, 2 \mathrm{H}) .{ }^{13} \mathrm{C}$ $\operatorname{NMR}\left(101 \mathrm{MHz}, \mathrm{CDCl}_{3}\right): \delta=212.82,153.28,148.48,140.49,126.99,111.51,108.38,108.22,63.91$, 56.51, 49.03, 40.93, 34.84. HRMS (ESI): Calcd for $\mathrm{C}_{16} \mathrm{H}_{17} \mathrm{~N}_{2} \mathrm{O}_{7}[\mathrm{M}+\mathrm{H}]^{+}:$349.1030, found: 349.1032 .

18.06. ${ }^{13} \mathrm{C}$ EPT135 NMR (101 MHz, $\mathrm{CDCl}_{3}: \delta=\left(\mathrm{CH}_{3} / \mathrm{CH}\right)$ 132.58, 127.98, 127.42, 123.96, 33.31,17.98; $\left(\mathrm{CH}_{2}\right) 68.82,40.59$, 34.69. $\mathrm{MS}$ (ESI): Calcd for $\mathrm{C}_{16} \mathrm{H}_{17} \mathrm{~N}_{2} \mathrm{O}_{5}[\mathrm{M}+\mathrm{H}]^{+}: 317.1$, found: $317.1[\mathrm{M}+\mathrm{H}]^{+}, 334.1\left[\mathrm{M}+\mathrm{NH}_{4}\right]^{+}, 339.1[\mathrm{M}+\mathrm{Na}]^{+}, 655.1$ $[2 \mathrm{M}+\mathrm{Na}]^{+}$. 
${ }^{1} \mathrm{H}$ NMR $(500 \mathrm{MHz})$

$\frac{0}{0}$
0
0
8
0

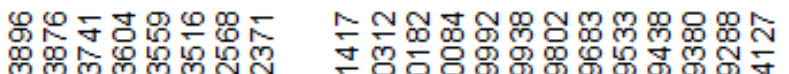

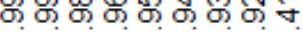

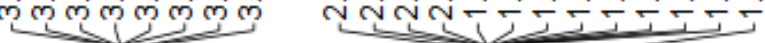

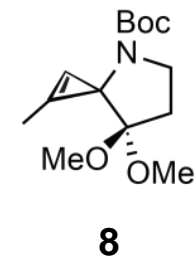

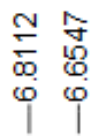
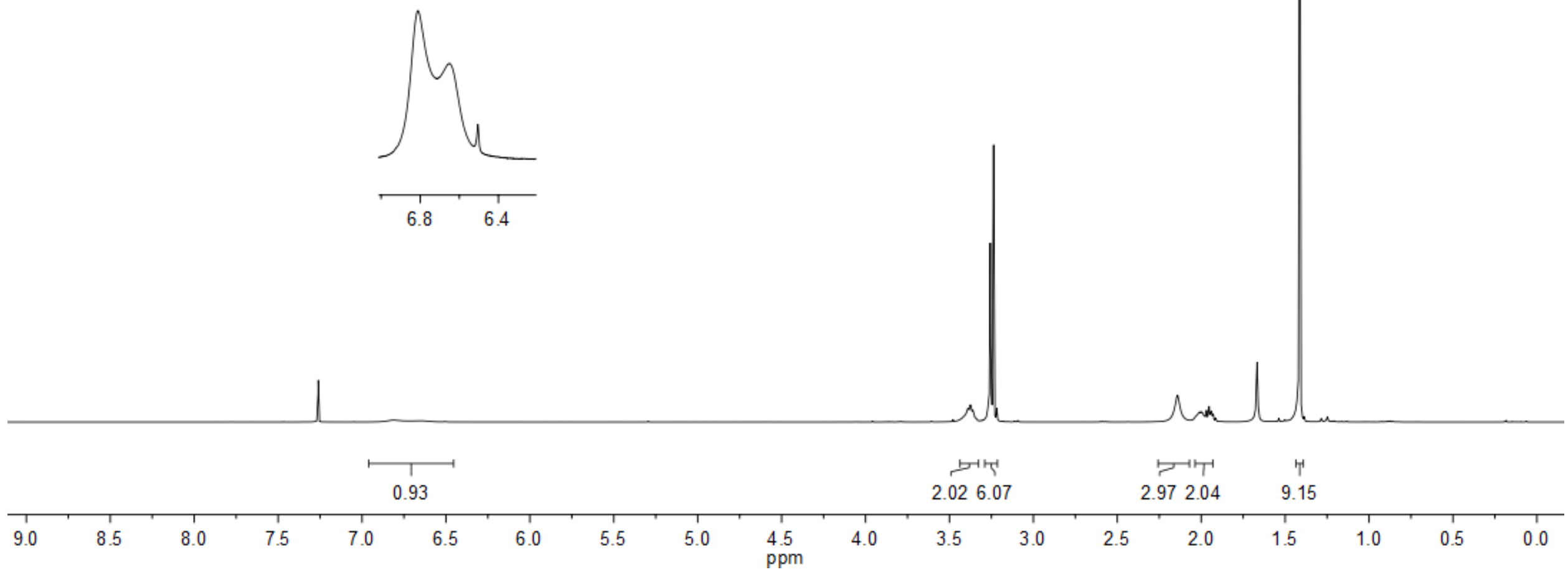

[47] 
${ }^{13} \mathrm{C}$ NMR (101 MHz)

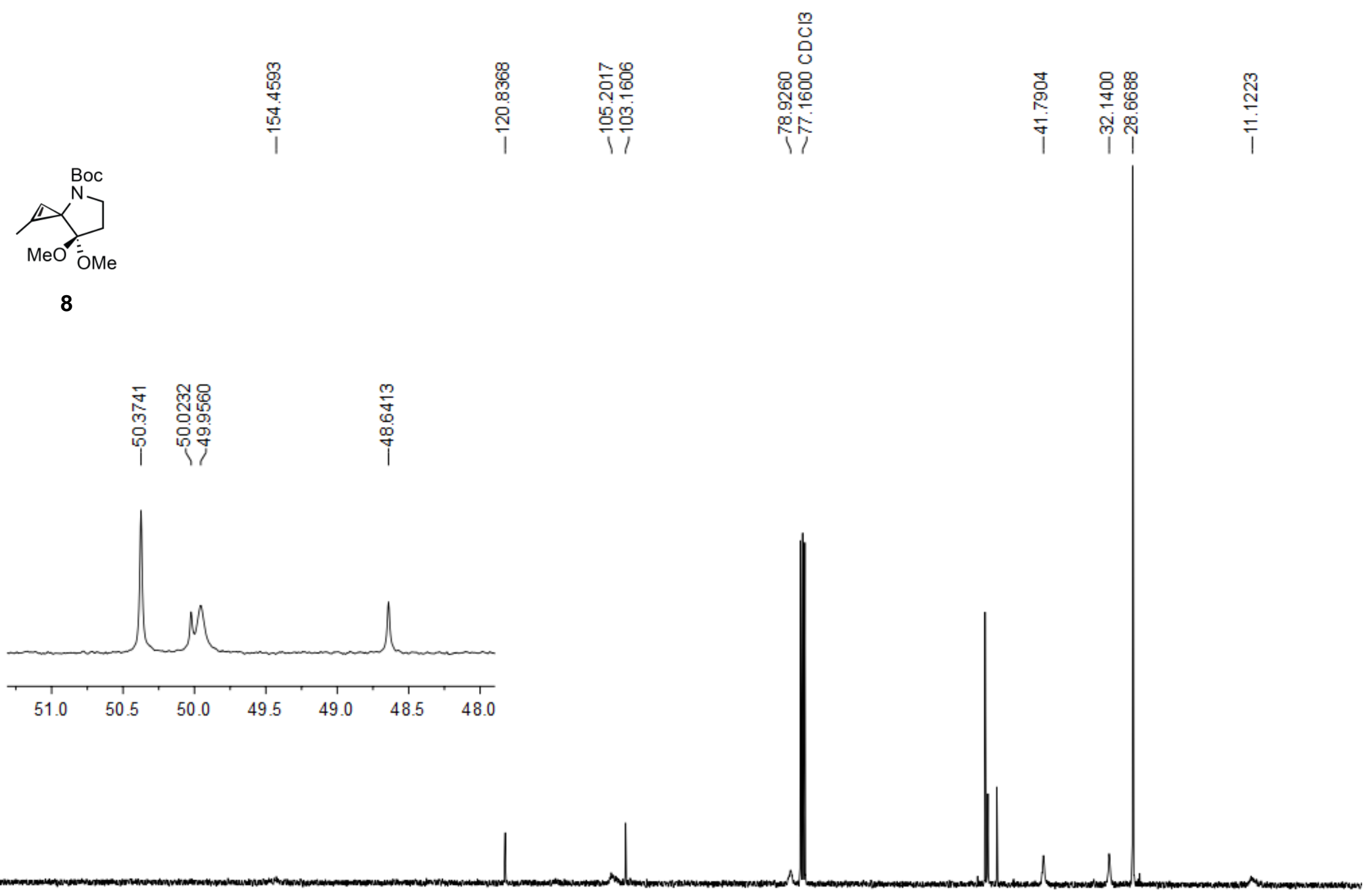

$10 \quad 20$

$190 \quad 180$

170

$160 \quad 150$

140

$130 \quad 120$ $110 \quad 100$

[48] 
COSY NMR $(400 \mathrm{MHz})$

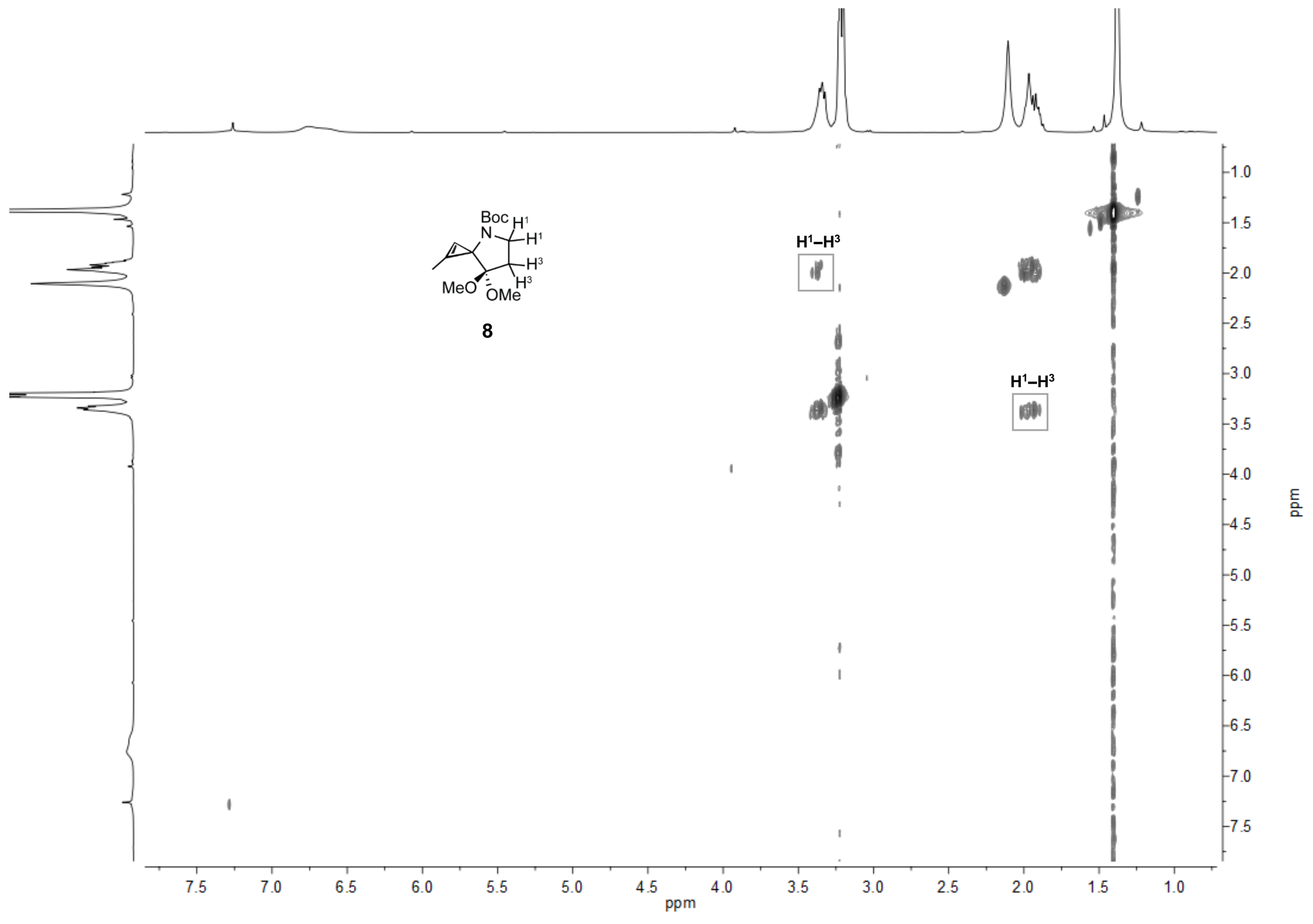

[49] 
${ }^{1} \mathrm{H}$ NMR $(400 \mathrm{MHz})$

$\begin{array}{ll}\frac{m}{0} & \\ 0 & \\ 0 & \\ 8 & 0 \\ 0 & 8 \\ & 0 \\ & 0\end{array}$

일

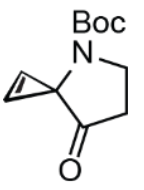

$9 a$

闩果

๓⿴囗十

शुल

ळธ

نंग
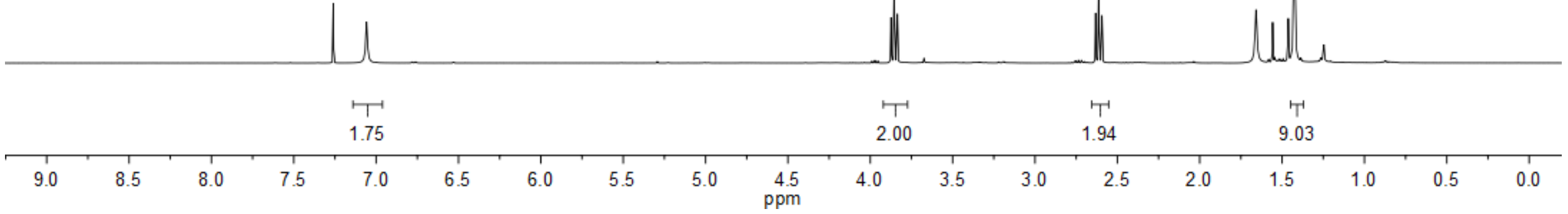

[50] 
${ }^{13} \mathrm{C}$ NMR $(101 \mathrm{MHz})$

ัㅗำ

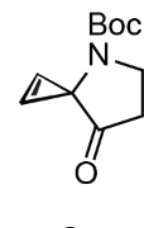

$9 a$

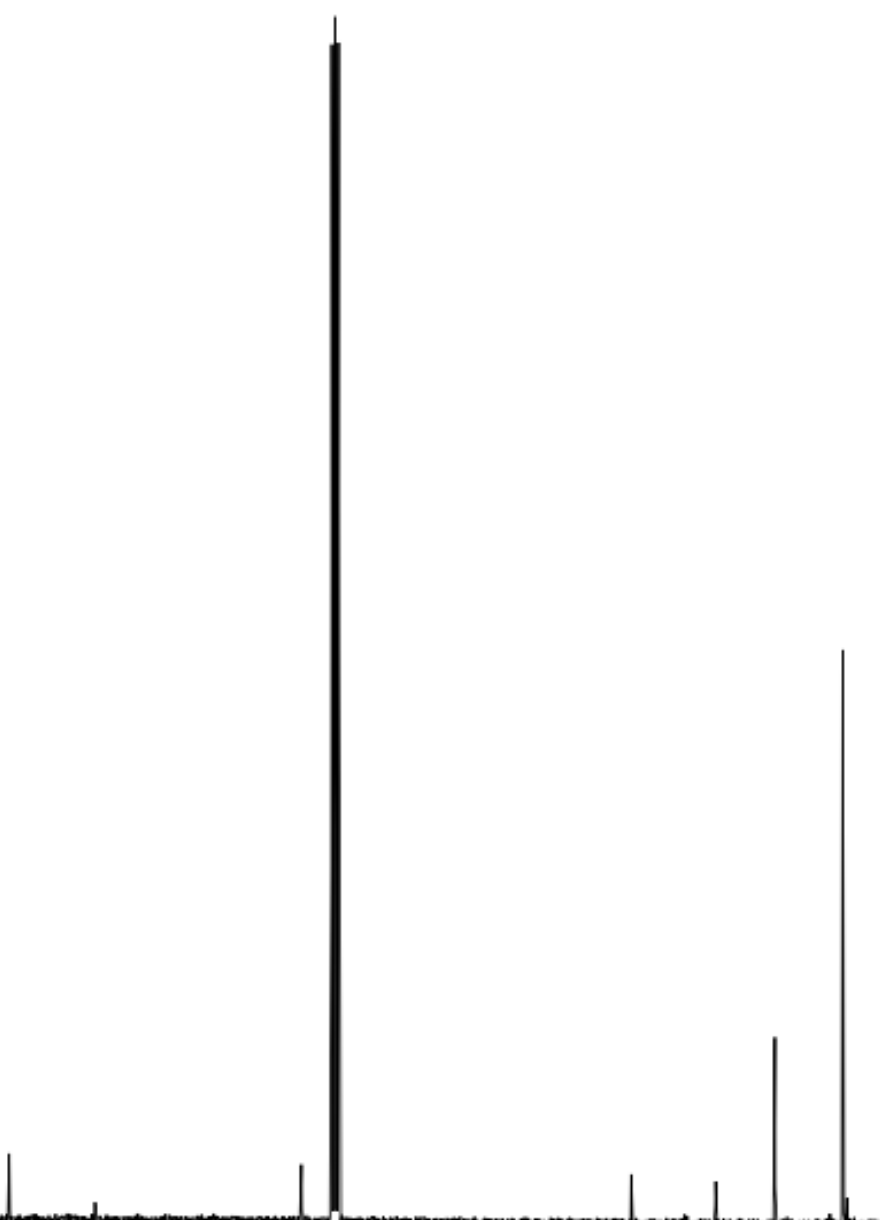


COSY NMR $(400 \mathrm{MHz})$

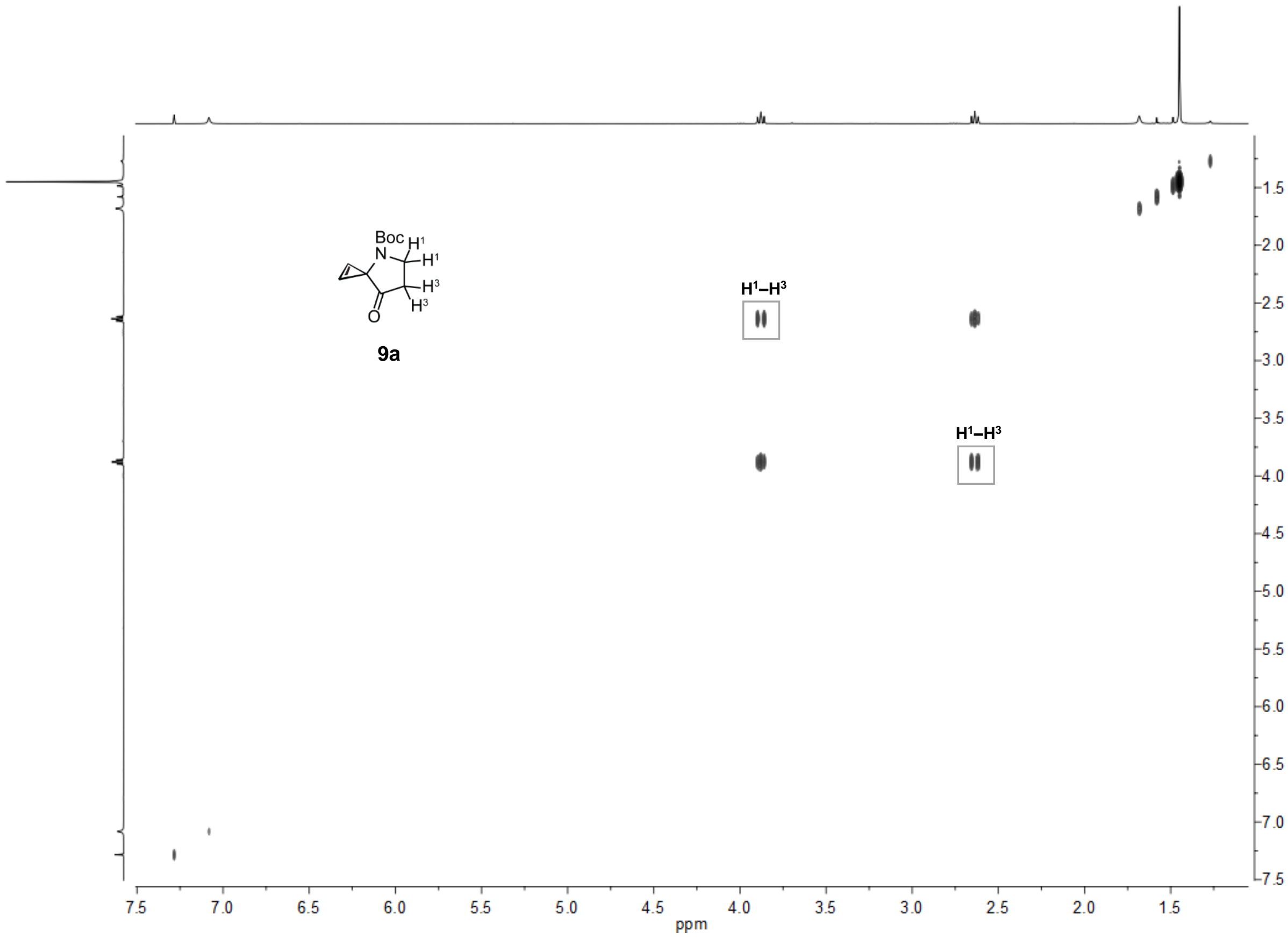

틀 
${ }^{1} \mathrm{H}$ NMR $(700 \mathrm{MHz})$

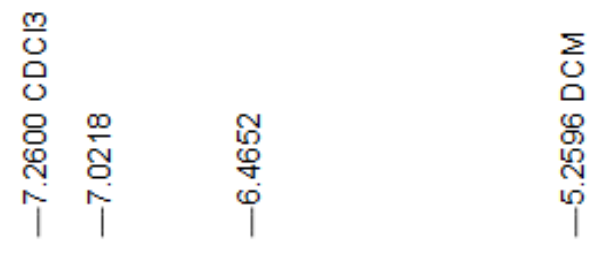
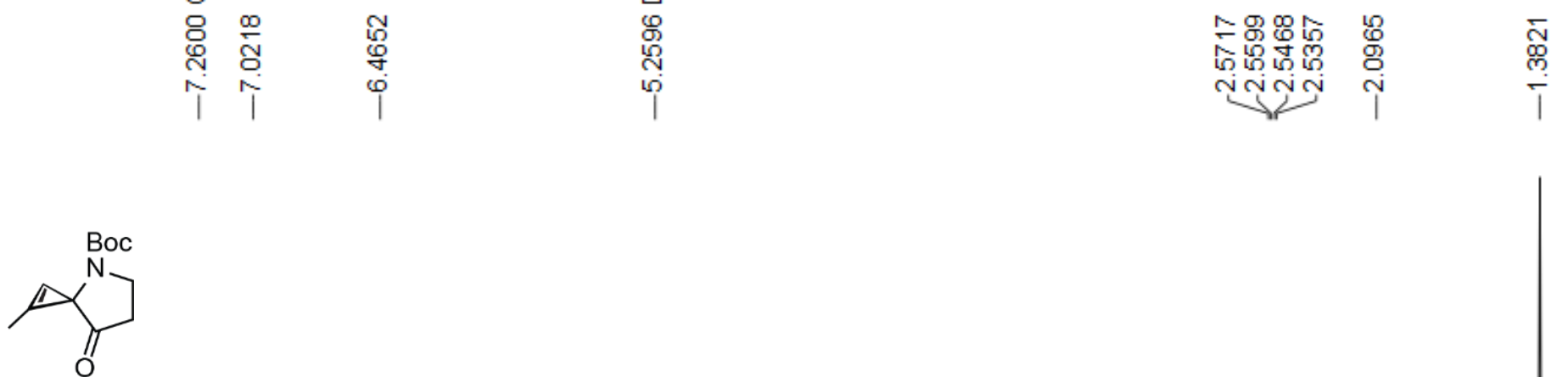

$9 b$

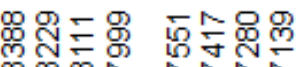

mon

लकm लmकल

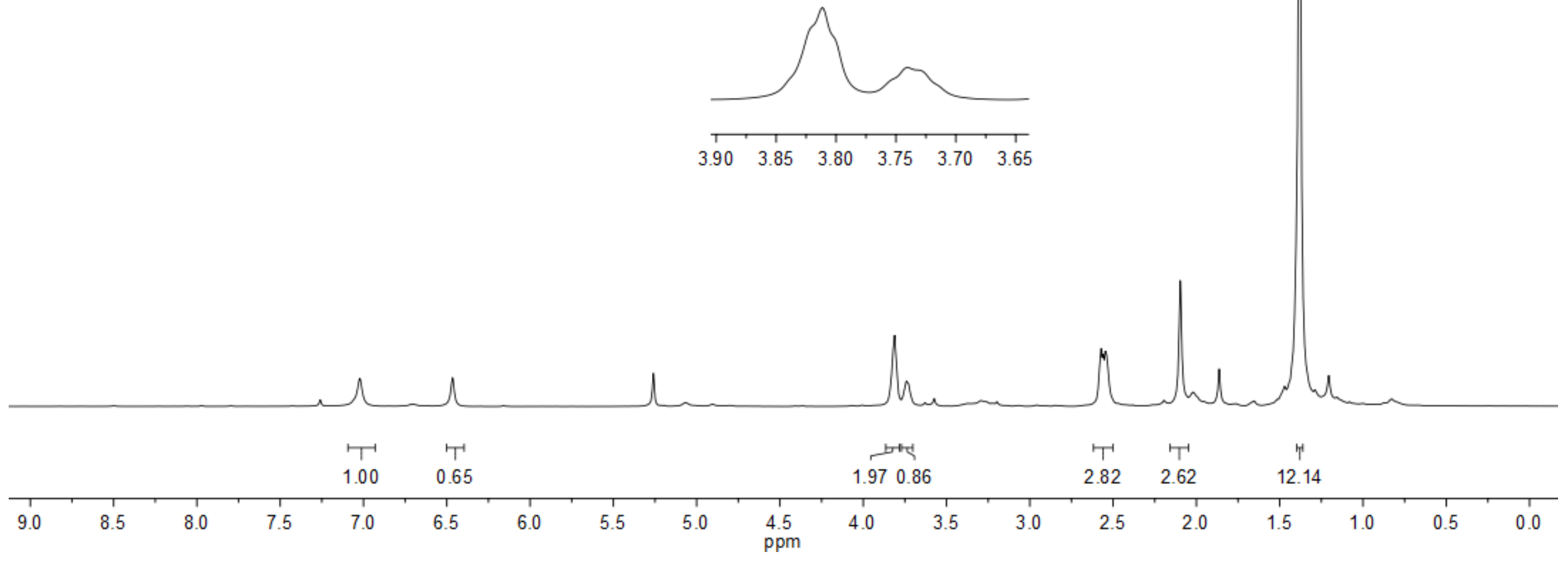

[53] 
${ }^{13} \mathrm{C}$ NMR $(176 \mathrm{MHz})$

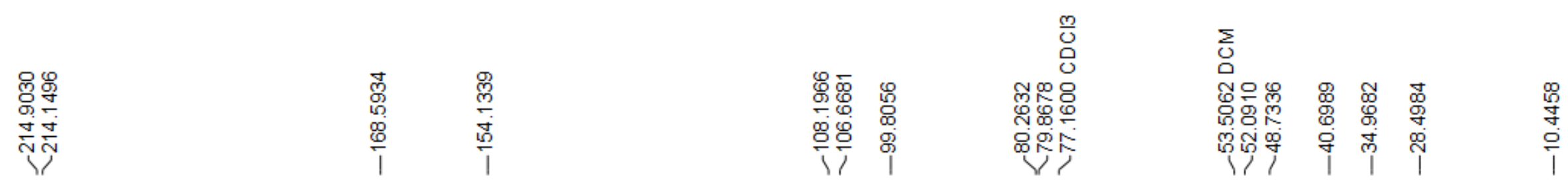
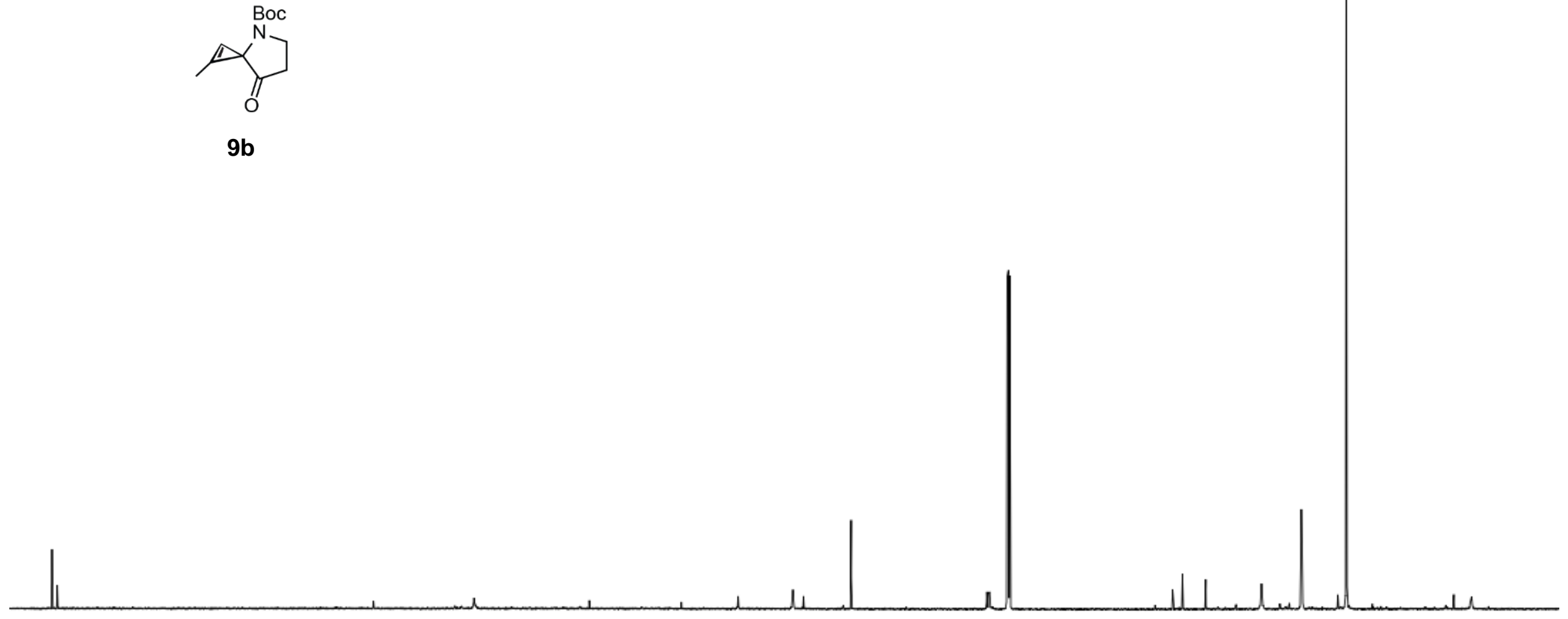
${ }^{1} \mathrm{H}$ NMR $(400 \mathrm{MHz})$

i
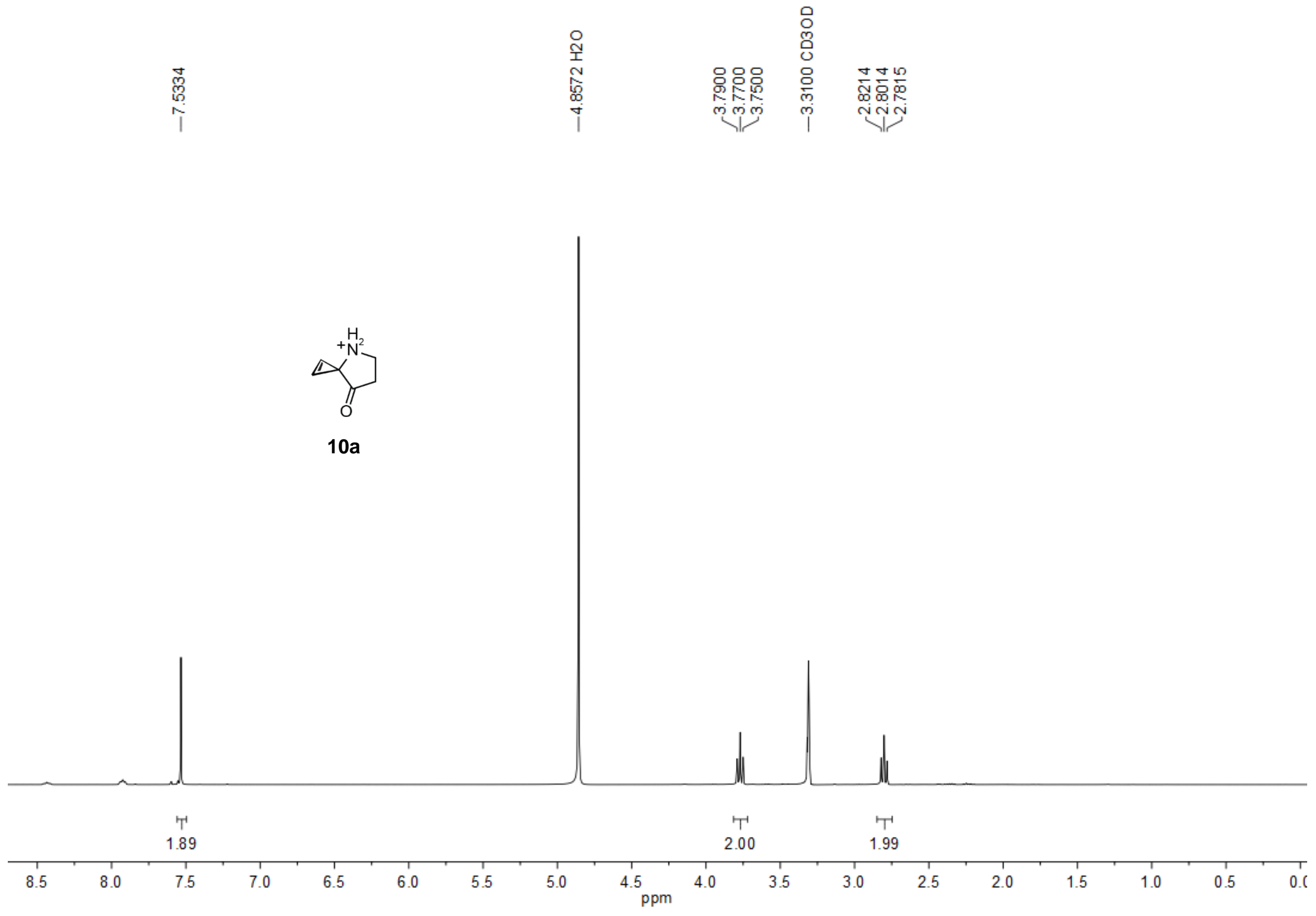
${ }^{13} \mathrm{C}$ NMR $(101 \mathrm{MHz})$

$\bar{్}$
ल.
o
।

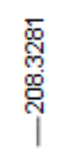
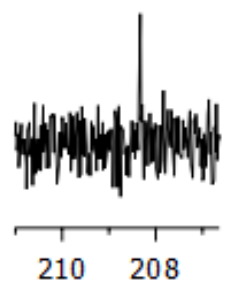

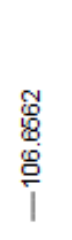

$10 a$
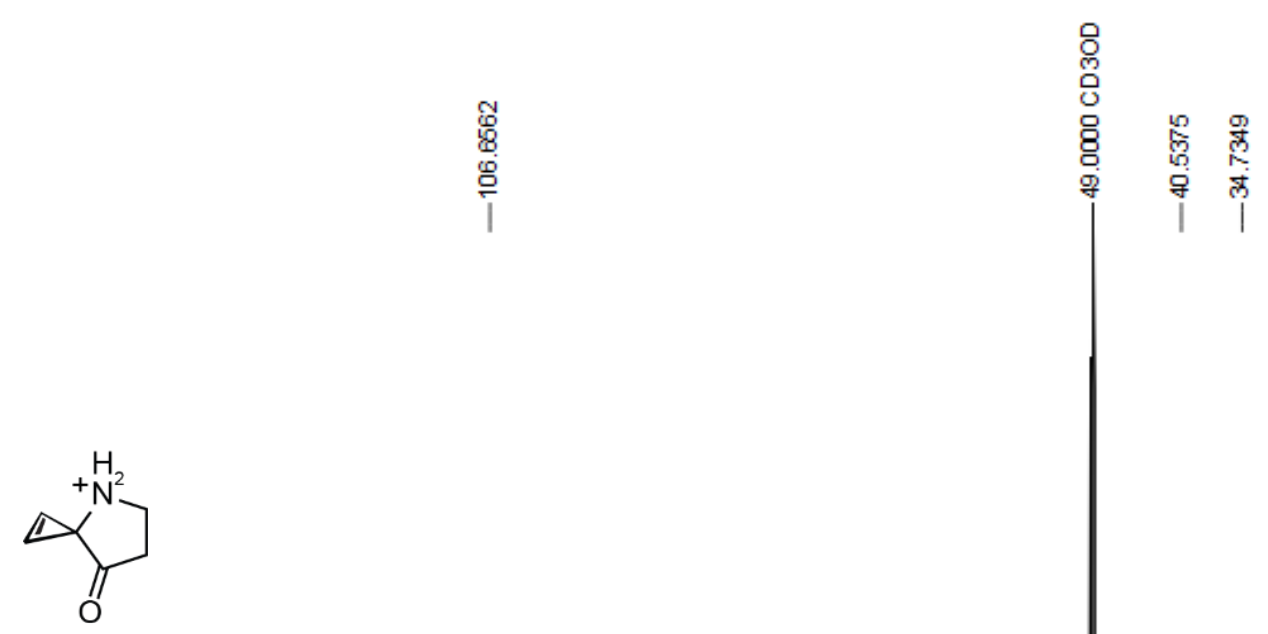

焉

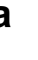

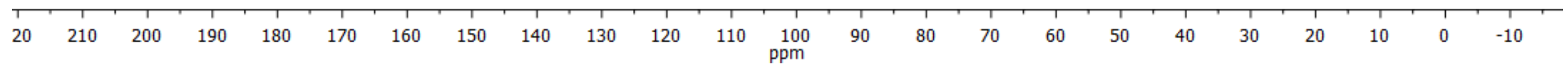

[56] 
COSY NMR $(400 \mathrm{MHz})$

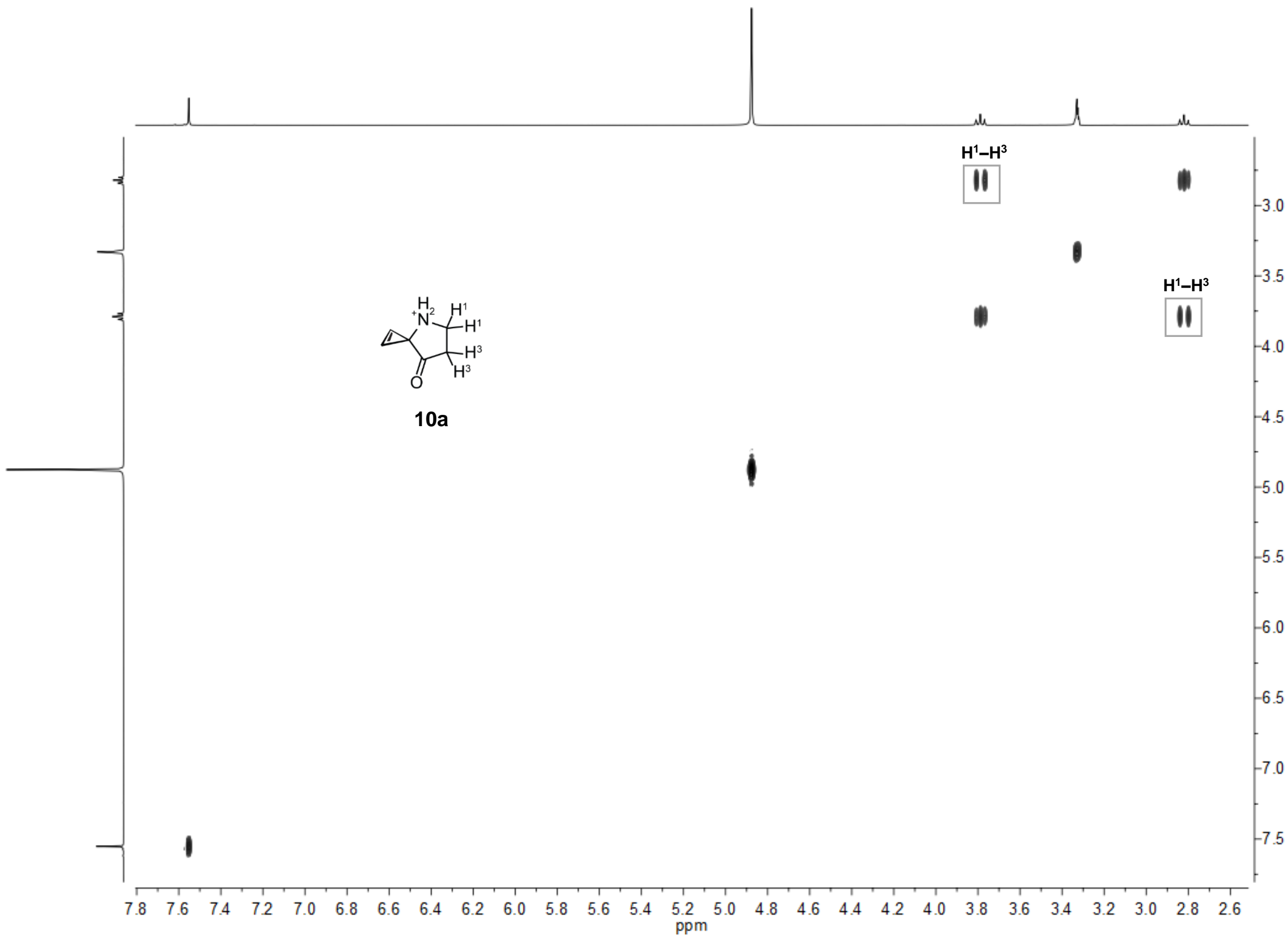


${ }^{1} \mathrm{H}$ NMR $(400 \mathrm{MHz})$
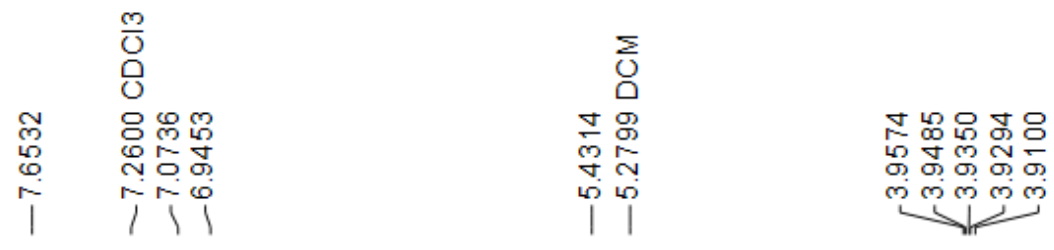

总骂曹

웅

نَj

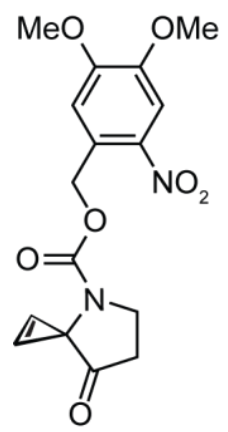

$11 a$

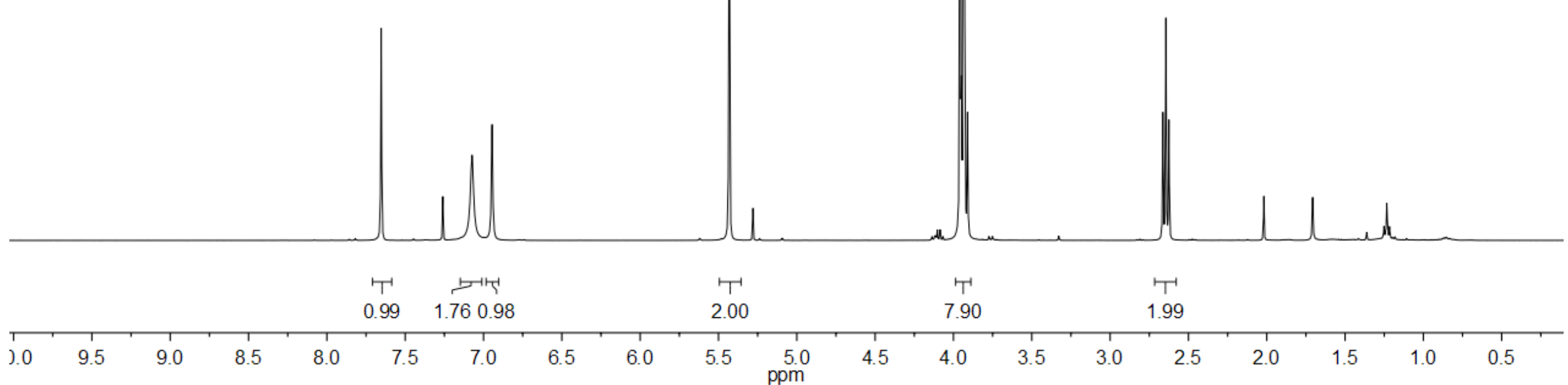


${ }^{13} \mathrm{C}$ NMR $(101 \mathrm{MHz})$

$\underset{\substack{n \\ \infty}}{\stackrel{\infty}{N}}$

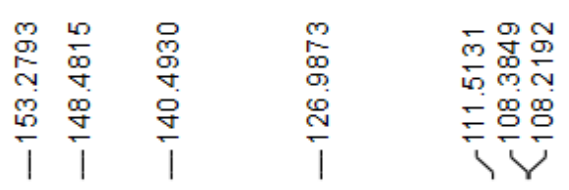

$\frac{m}{0}$
0
0
0
0
0
0

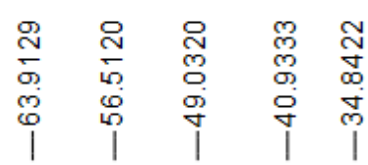

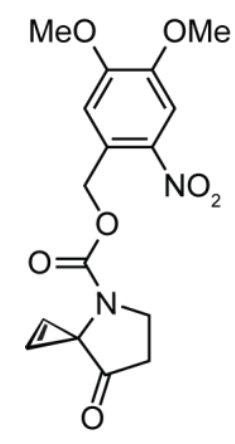

$11 a$

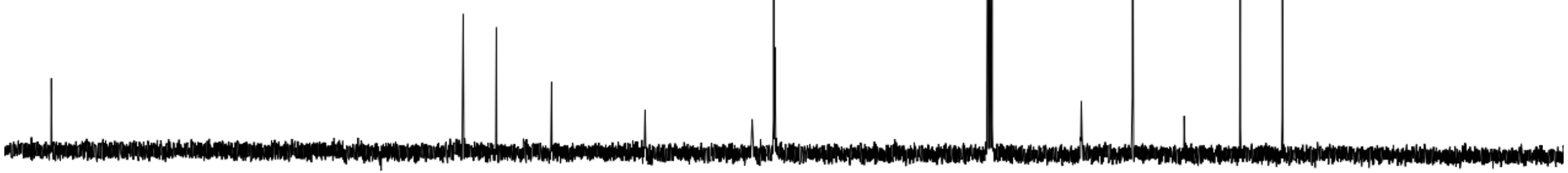

$210 \quad 200$ 
DEPT135 NMR (400 MHz)

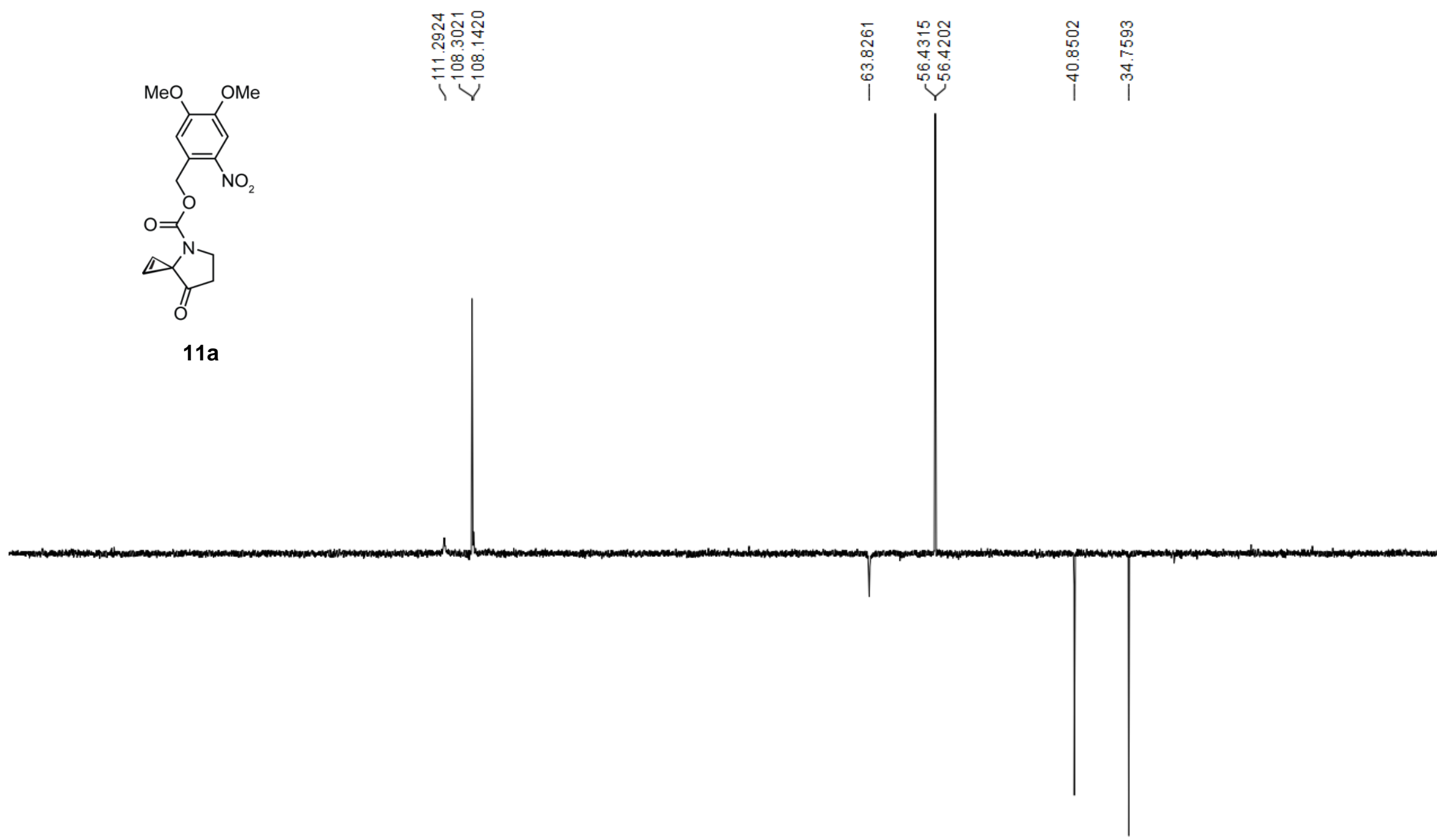

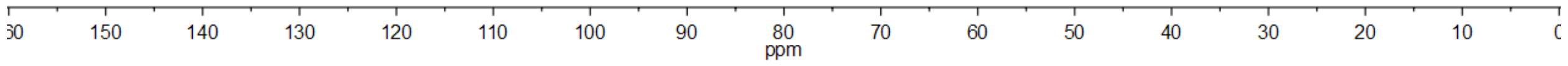


${ }^{1} \mathrm{H}$ NMR $(400 \mathrm{MHz})$

商

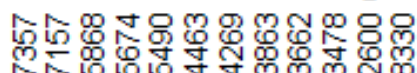

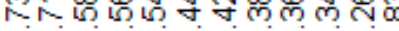

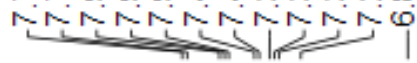

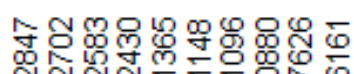

กงก

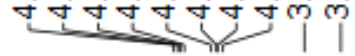

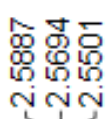

핳 윰

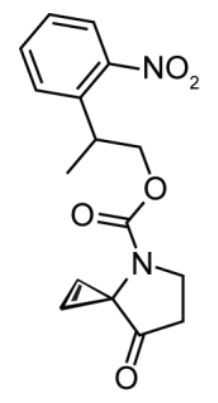

11b

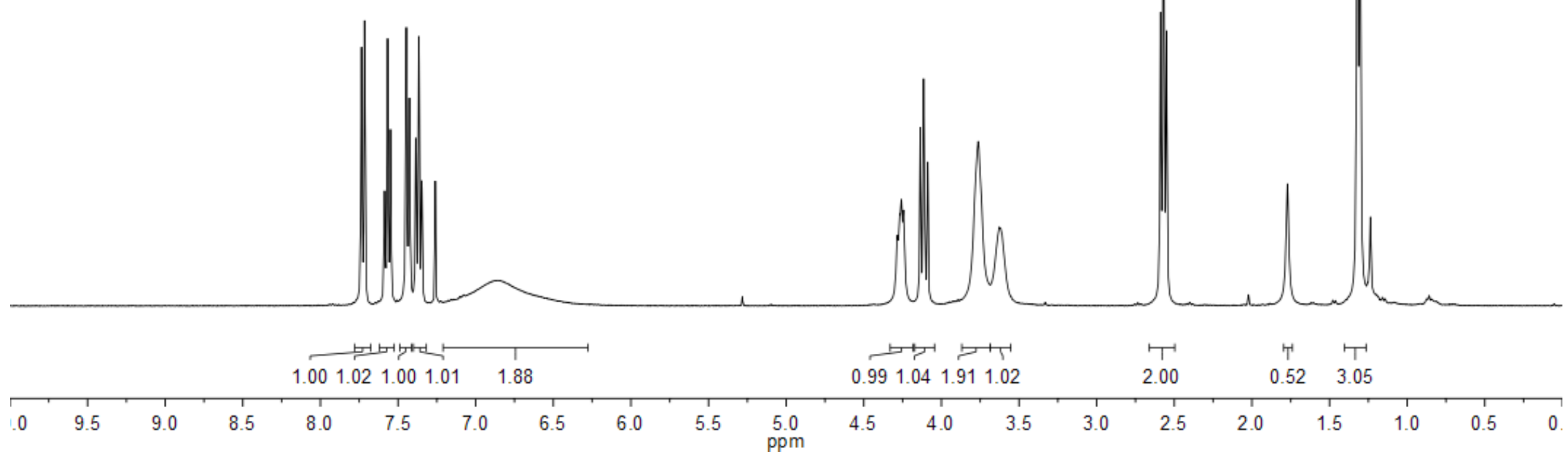


${ }^{13} \mathrm{C}$ NMR $(101 \mathrm{MHz})$

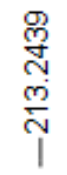

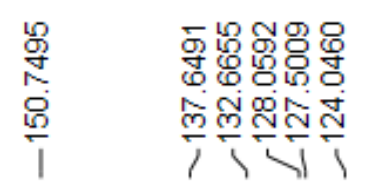

$\frac{m}{8}$
$\frac{9}{10}$
$\frac{9}{1}$

\begin{tabular}{ll}
$\frac{m}{0}$ & \\
0 & \\
0 & $\bar{g}$ \\
0 & 0 \\
\hdashline & 0 \\
& 0
\end{tabular}

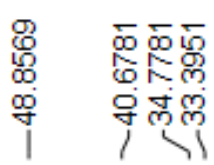

$\frac{7}{8}$
$\frac{1}{9}$

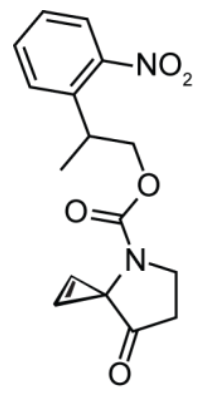

11b
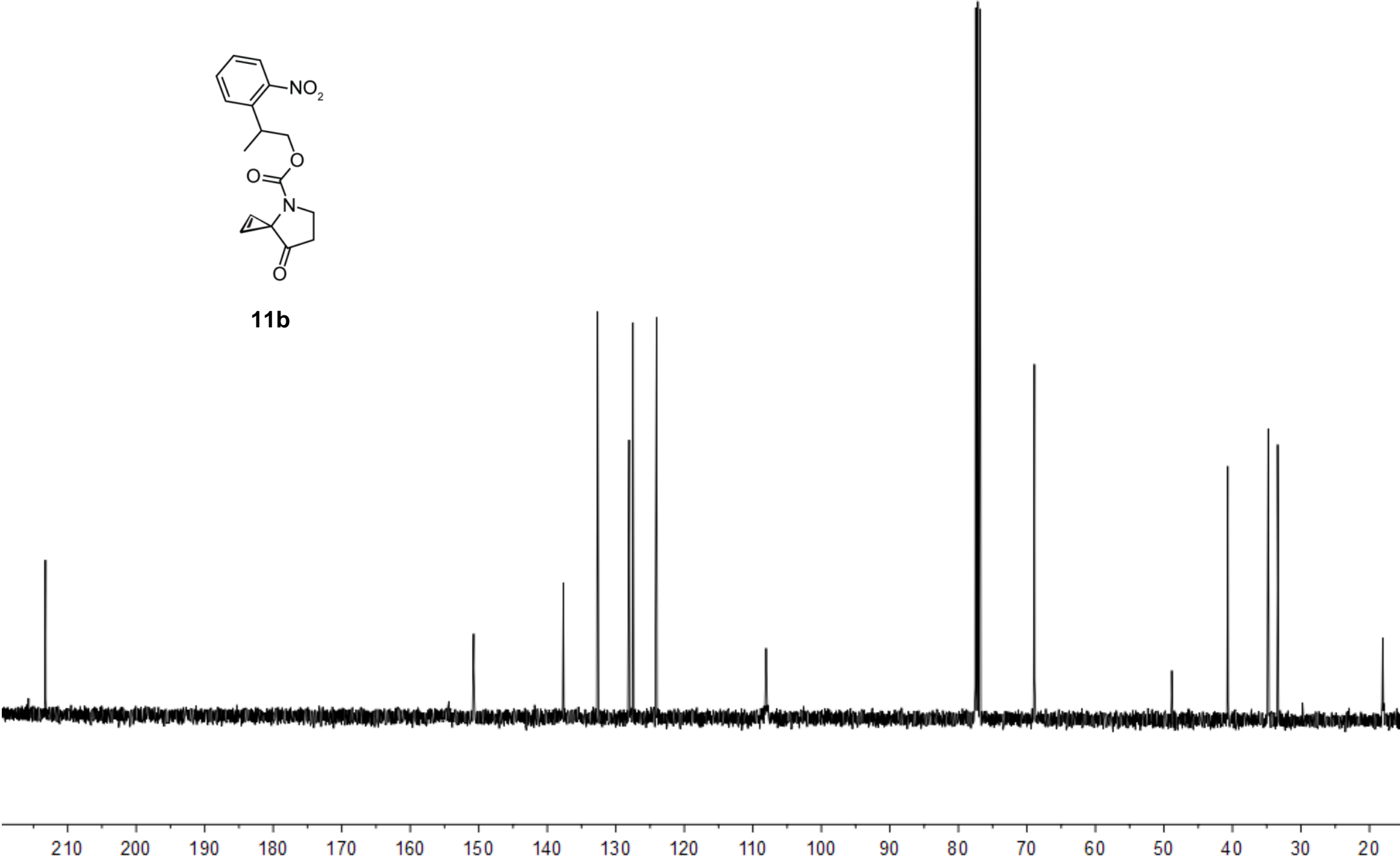
${ }^{13} \mathrm{C}$-DEPT135 NMR (101 MHz)
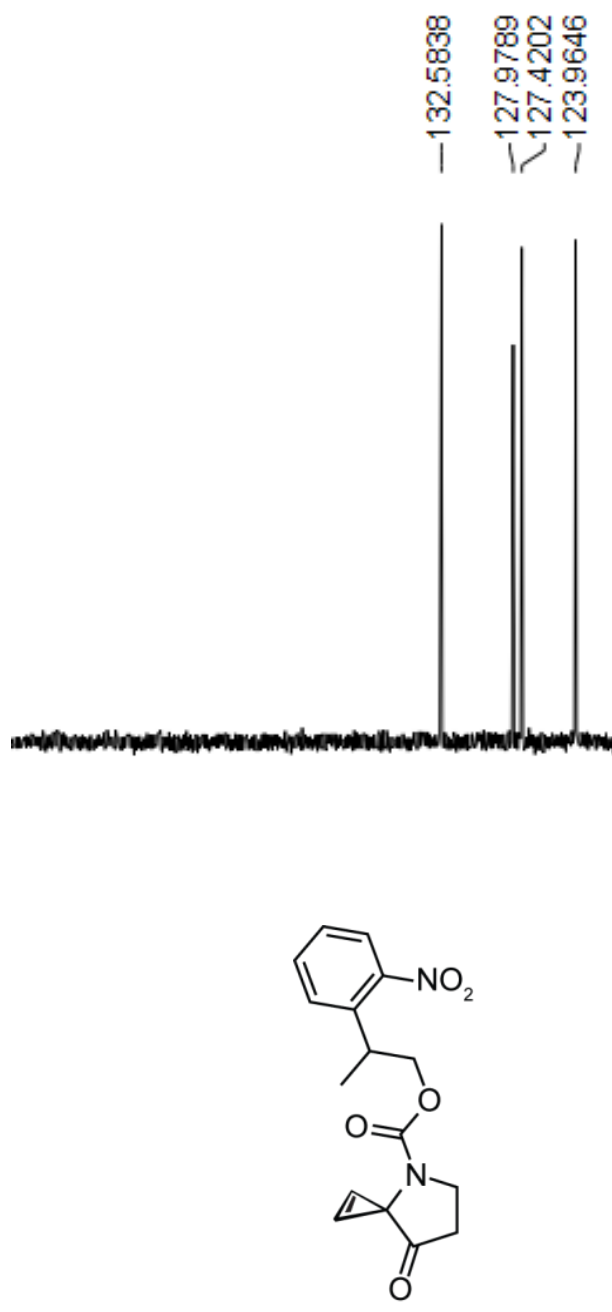

11b 


\section{Scheme S5: Synthesis procedures for S6, 12-13}
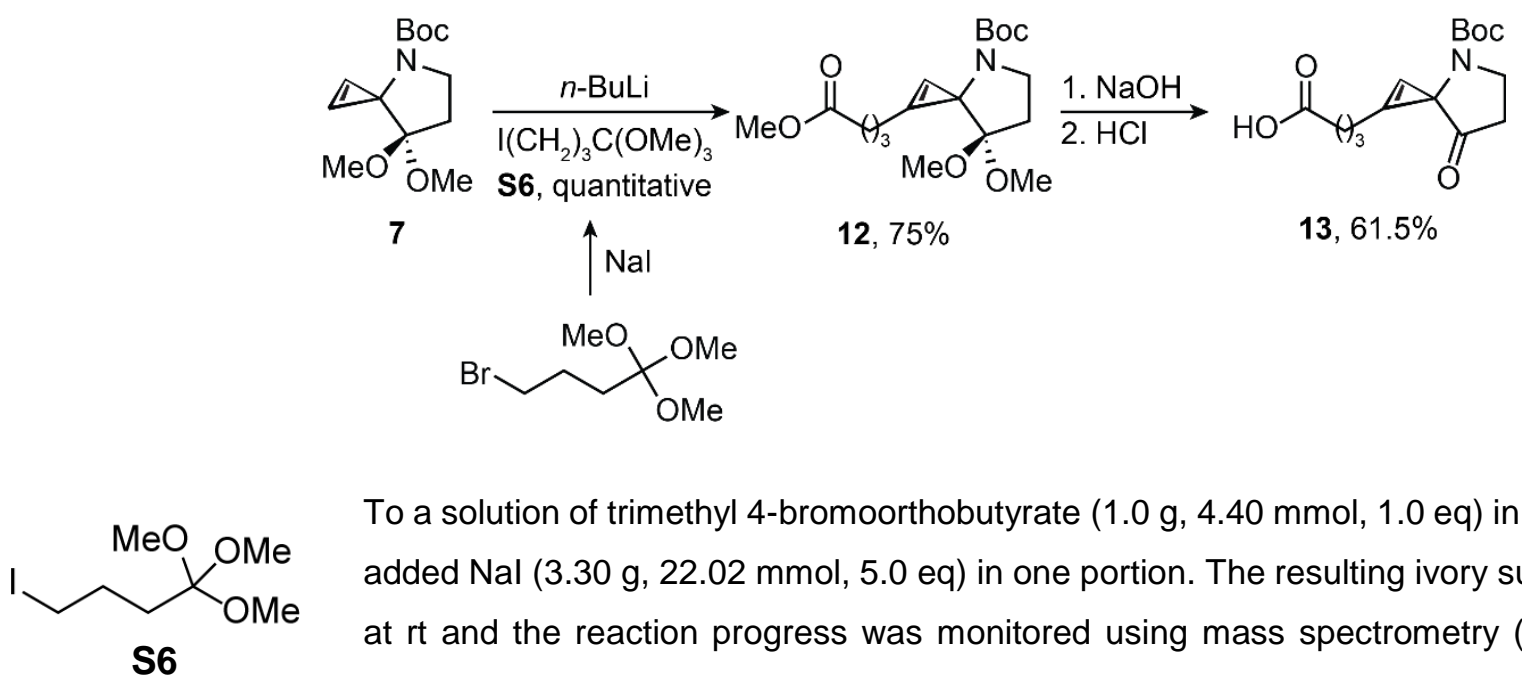

To a solution of trimethyl 4-bromoorthobutyrate $(1.0 \mathrm{~g}, 4.40 \mathrm{mmol}, 1.0 \mathrm{eq})$ in acetone $(20 \mathrm{~mL})$ was added $\mathrm{Nal}(3.30 \mathrm{~g}, 22.02 \mathrm{mmol}, 5.0 \mathrm{eq})$ in one portion. The resulting ivory suspension was stirred at $\mathrm{rt}$ and the reaction progress was monitored using mass spectrometry $(\sim 20 \mathrm{~h})$. The reaction mixture was concentrated in vacuo and extracted with DCM and water. The combined organic layer was washed with brine, dried over anhydrous $\mathrm{Na}_{2} \mathrm{SO}_{4}$ and concentrated in vacuo to obtain $\mathbf{S 6}$ (1.25 g, quantitative) as a pale-yellow oil that was used immediately without further purification. Attempts to purify $\mathbf{S 6}$ using silica gel chromatography resulted in conversion of the trimethyl orthoformate group to the methyl ester, therefore, it was used without further purification. Multiple repetitions of this reaction $(>5)$ starting from different amounts of bromo-starting material on different days, and by 4 different personnel, provided comparable yields. $\left.{ }^{1} \mathrm{H} N \mathrm{NR}(700 \mathrm{MHz}, \mathrm{CDCl})_{3}\right): \delta=3.23(\mathrm{~s}, 9 \mathrm{H}), 3.22-$ $3.19(\mathrm{~m}, 2 \mathrm{H}), 1.86-1.83(\mathrm{~m}, 4 \mathrm{H}) .{ }^{13} \mathrm{C}$ NMR $\left(126 \mathrm{MHz}, \mathrm{CDCl}_{3}\right): \delta$ 115.33, 49.56, 31.35, 27.18, 7.15. HRMS (ESI): Calcd for $\mathrm{C}_{7} \mathrm{H}_{15} \mathrm{IO}_{3}[\mathrm{M}-\mathrm{OMe}]^{+}: 242.9882$, found: 242.9876.

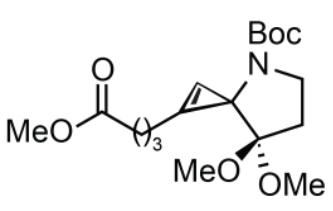

12

To a solution of 7 (375 mg, $1.47 \mathrm{mmol}, 1.0 \mathrm{eq})$ in anhydrous THF (20.0 mL) was added HMPA (527 mg, $512 \mu \mathrm{L}, 2.94 \mathrm{mmol}, 2.0 \mathrm{eq}$ ) under an atmosphere of $\mathrm{N}_{2}$. The reaction mixture was stirred at $r$ for 10 mins and then cooled to $-78^{\circ} \mathrm{C}$. To this pale-yellow solution was added n-BuLi (1.1 $\mathrm{mL}, 1.6 \mathrm{M}$ in hexane, $1.76 \mathrm{mmol}, 1.2 \mathrm{eq})$ dropwise. $\mathbf{S 6}(1.2 \mathrm{~g}, 4.42 \mathrm{mmol}, 3.0 \mathrm{eq})$ as a solution in anhydrous THF $(4.0 \mathrm{~mL})$ was added to the reaction mixture at $-78^{\circ} \mathrm{C}$. The resulting yellow mixture was stirred for $3.0 \mathrm{~h}$ while allowing the reaction temperature to warm gradually, at which point it was quenched with saturated $\mathrm{NH}_{4} \mathrm{Cl}$, and extracted with $\mathrm{DCM}$ and water. The combined organic layer was dried over anhydrous $\mathrm{Na}_{2} \mathrm{SO}_{4}$, concentrated in vacuo, and purified by flash chromatography (60 g silica, 20-25\% EtOAc/hexanes (v/v)) to obtain 12 as a pale-yellow oil (376 mg, 79\%). Multiple repetitions of this reaction ( $>5$ ) starting from different amounts of 7 , on different days, and by 3 different personnel, provided comparable yields.

Another instance of this reaction using slightly different molar equivalents of the $\mathbf{S 6}$ was also carried out: To a solution of 7 (72.6 mg, $0.28 \mathrm{mmol}, 1.0 \mathrm{eq})$ in anhydrous THF $(8.0 \mathrm{~mL})$ was added HMPA (103 mg, $100 \mu \mathrm{L}, 0.575 \mathrm{mmol}, 2.0$ eq) under an atmosphere of $\mathrm{N}_{2}$. The reaction mixture was stirred at rt for 10 mins and then cooled to $-78{ }^{\circ} \mathrm{C}$. To this paleyellow solution was added n-BuLi ( $213 \mu \mathrm{L}, 1.6 \mathrm{M}$ in hexane, $0.34 \mathrm{mmol}, 1.2 \mathrm{eq})$ dropwise. $\mathbf{S 6}$ (195 mg, $0.71 \mathrm{mmol}, 2.5 \mathrm{eq})$ as a solution in anhydrous THF $(1.0 \mathrm{~mL})$ was added to the reaction mixture at $-78{ }^{\circ} \mathrm{C}$. The resulting yellow mixture was stirred for $3.5 \mathrm{~h}$ while allowing the reaction temperature to warm gradually, at which point it was quenched with saturated $\mathrm{NH}_{4} \mathrm{Cl}$ and extracted with $\mathrm{DCM}$ and water. The combined organic layer was dried over anhydrous $\mathrm{Na}_{2} \mathrm{SO}_{4}$, concentrated in vacuo, and purified by flash chromatography (16 g silica, 20-25\% EtOAc/hexanes (v/v)) to obtain 12 as a pale-yellow oil (74 mg, 73.3\%). 
$\mathrm{R}_{\mathrm{f}}=0.33\left(30 \%\right.$ EtOAc/hexanes, visualized $\left.\mathrm{w} / \mathrm{KMnO}_{4}\right) .{ }^{1} \mathrm{H}$ NMR $\left(400 \mathrm{MHz}, \mathrm{CDCl}_{3}\right): \delta=6.48-7.13(\mathrm{~m}, 1 \mathrm{H}), 3.77-$ $3.87(\mathrm{~m}, 0.75 \mathrm{H}), 3.51(\mathrm{~s}, 1.70 \mathrm{H}), 3.23(\mathrm{dd}, J=9.4,4.0 \mathrm{~Hz}, 2 \mathrm{H}), 3.09-3.12(\mathrm{~m}, 4 \mathrm{H}), 3.08(\mathrm{~s}, 2 \mathrm{H}), 3.03(\mathrm{~s}, 1 \mathrm{H}), 2.37(\mathrm{p}, J=$ 8.6, $7.3 \mathrm{~Hz}, 1 \mathrm{H}), 2.25(\mathrm{t}, J=7.4 \mathrm{~Hz}, 1 \mathrm{H}), 1.91-2.00(\mathrm{~m}, 2.2 \mathrm{H}), 1.70-1.88(\mathrm{~m}, 2.5 \mathrm{H}), 1.26(\mathrm{~s}, 9 \mathrm{H}) .{ }^{13} \mathrm{C} \mathrm{NMR}(126 \mathrm{MHz}$ $\left.\mathrm{CDCl}_{3}\right): \delta=173.84,155.36,154.41,125.86,125.39,106.19,105.67,102.83,102.46,79.55,78.99,51.62,50.93,50.37$, $49.80,49.62,48.77,41.79,41.34,38.01,37.94,33.33,32.32,31.81,28.68,24.05,22.51$. COSY NMR (400 MHz, CDCl 3 , attached) was obtained under the same conditions. HRMS (ESI): Calcd for $\mathrm{C}_{18} \mathrm{H}_{29} \mathrm{NO}_{6} \mathrm{Na}[\mathrm{M}+\mathrm{Na}]^{+}: 378.1887$, found: 378.1878 .

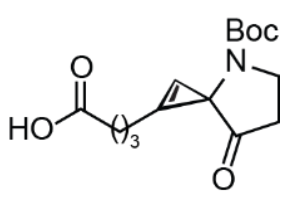

13

To a solution of $12(376 \mathrm{mg}, 1.06 \mathrm{mmol})$ in $\mathrm{MeOH}(15.0 \mathrm{~mL})$ was added $1 \mathrm{M} \mathrm{NaOH}(15.0 \mathrm{~mL})$ dropwise at $\mathrm{rt}$ and the reaction mixture was allowed to stir overnight. The reaction was concentrated in vacuo, diluted with $\mathrm{DCM}$, water, and $1 \mathrm{M} \mathrm{NaOH}(7.0 \mathrm{~mL})$. The aqueous layer was washed with DCM. The aqueous layer was then acidified to $\mathrm{pH} 1-2$ using $2 \mathrm{M} \mathrm{HCl}$ and extracted with DCM. The combined organic layer was dried over anhydrous $\mathrm{Na}_{2} \mathrm{SO}_{4}$ and concentrated in vacuo to obtain 13 as a pale-yellow oil (192 $\mathrm{mg}, 61.5 \%$ ). Multiple repetitions of this reaction (>3) starting from different amounts of 12, on different days, and by 2 different personnel, provided comparable yields. $R_{f}=0.15$ (40\% EtOAc/hexanes, visualized w/ $\left.\mathrm{KMnO}_{4}\right) .{ }^{1} \mathrm{H} \mathrm{NMR}\left(400 \mathrm{MHz}, \mathrm{CDCl}_{3}\right)$ : $\delta=6.56(\mathrm{~s}, 1 \mathrm{H}), 3.76-3.88(\mathrm{~m}, 2 \mathrm{H}), 2.41-2.65(\mathrm{~m}$, $4 \mathrm{H}), 2.43(\mathrm{t}, J=7.4 \mathrm{~Hz}, 2 \mathrm{H}), 1.86-1.94(\mathrm{~m}, 2 \mathrm{H}), 1.41(\mathrm{~s}, 9 \mathrm{H}) .{ }^{13} \mathrm{C} \mathrm{NMR}\left(101 \mathrm{MHz}, \mathrm{CDCl}_{3}\right): \delta=214.74,178.18,154.09$, $119.23,100.20,80.21,52.04,40.90,34.89,33.11,28.60,24.40,22.05$. COSY NMR (400 MHz, CDCl 3 , attached) was obtained under the same conditions. HRMS (ESI): Calcd for $\mathrm{C}_{15} \mathrm{H}_{21} \mathrm{NO}_{5} \mathrm{Na}[\mathrm{M}+\mathrm{Na}]^{+}: 318.1312$, found: 318.1292. 
${ }^{1} \mathrm{H}$ NMR $(700 \mathrm{MHz})$

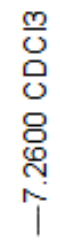

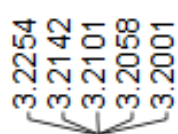
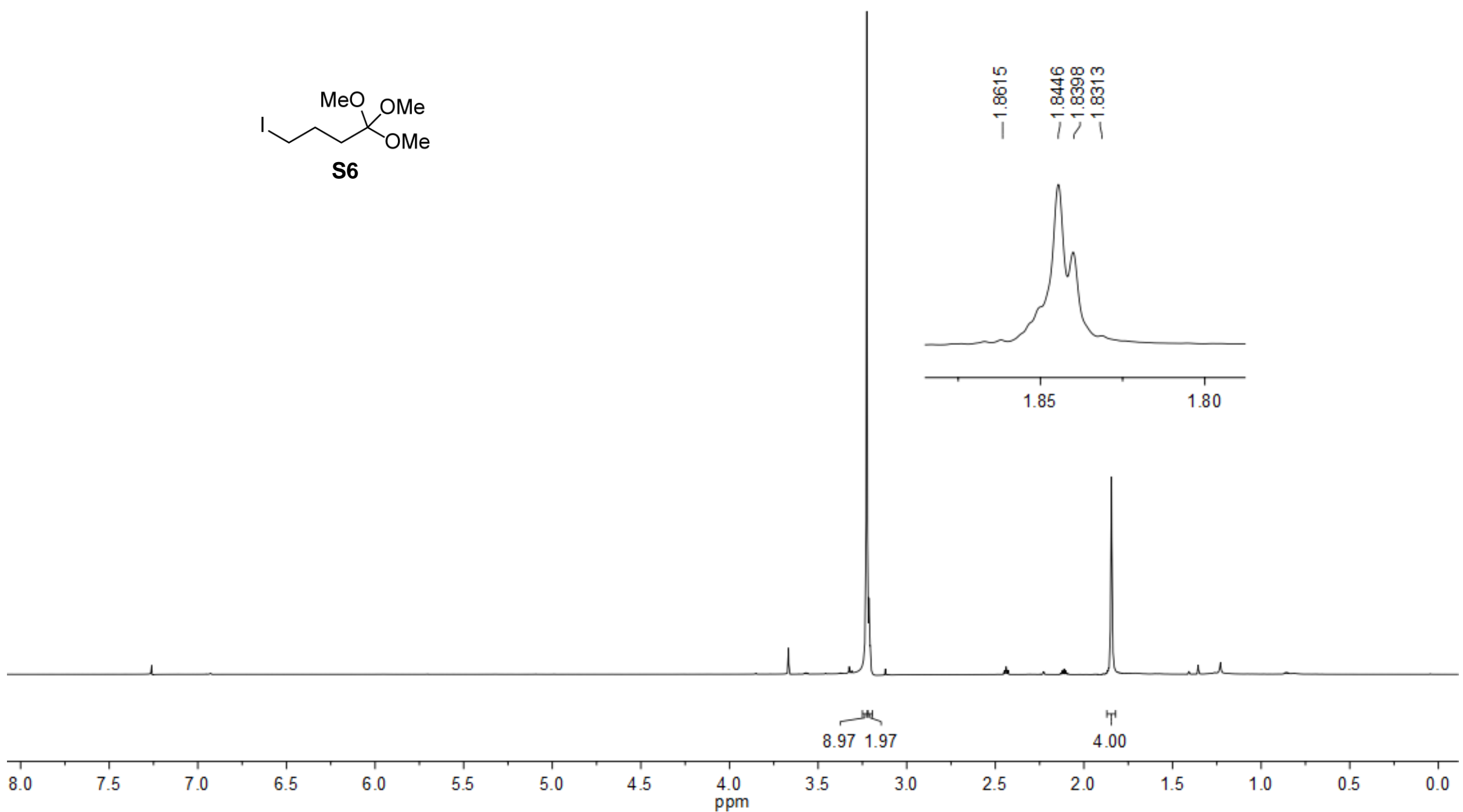

[66] 
${ }^{13} \mathrm{C}$ NMR (176 MHz)

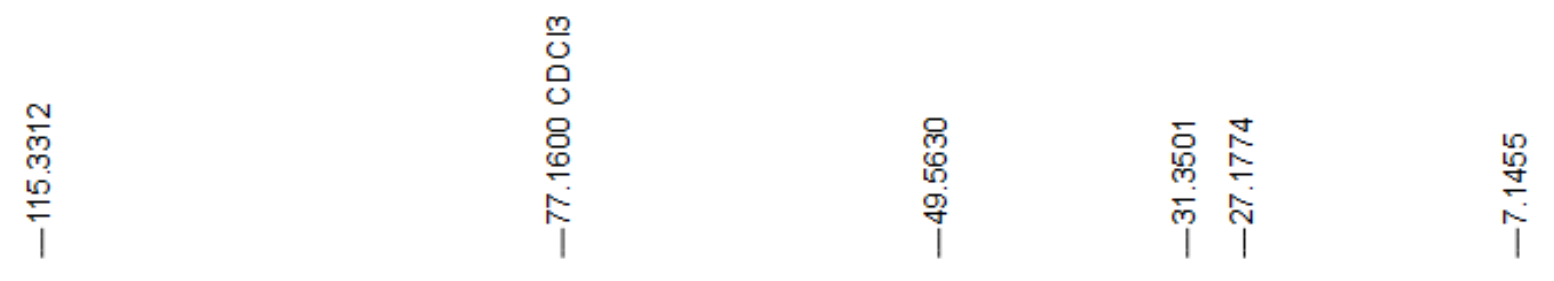
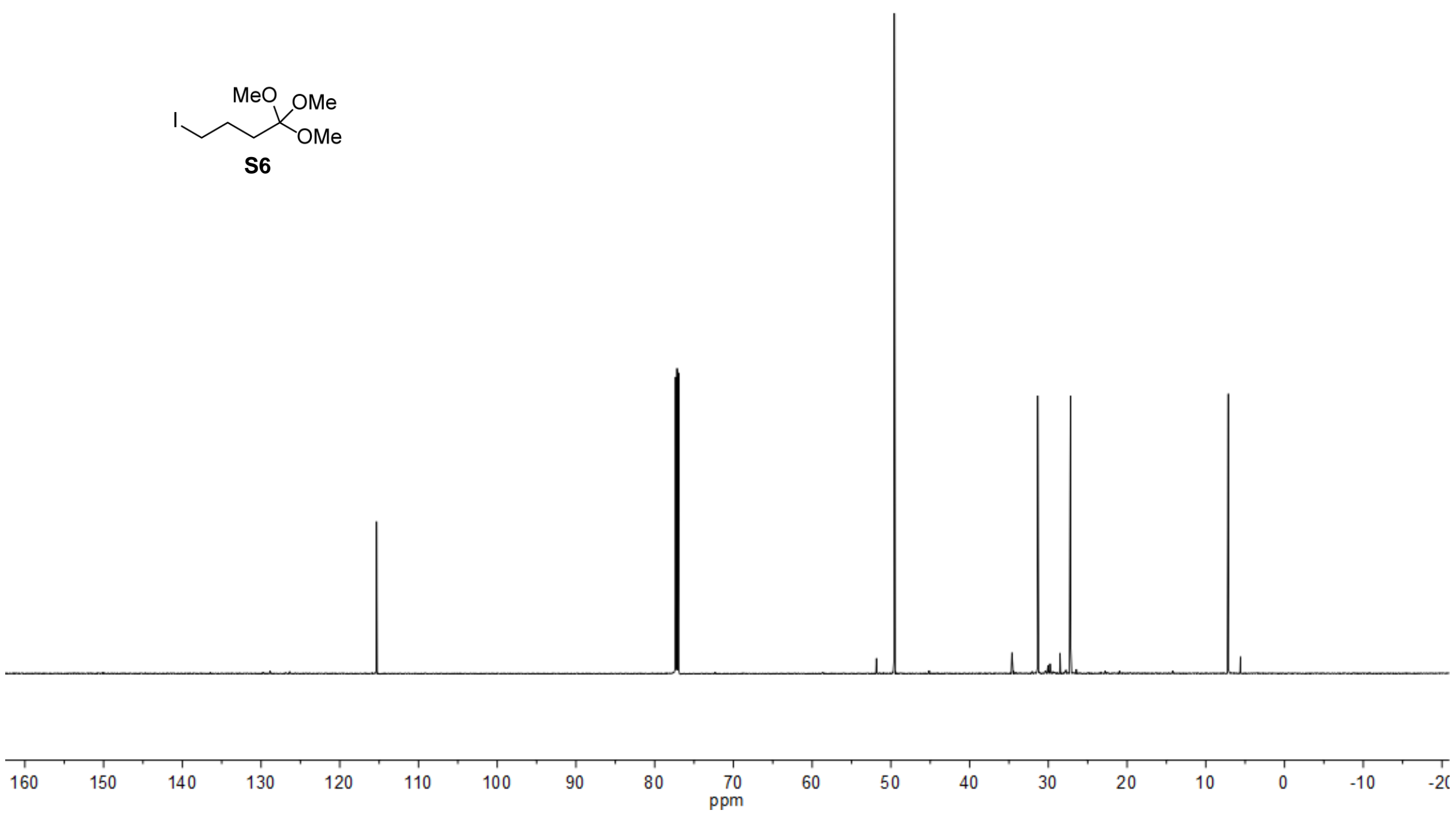

[67] 


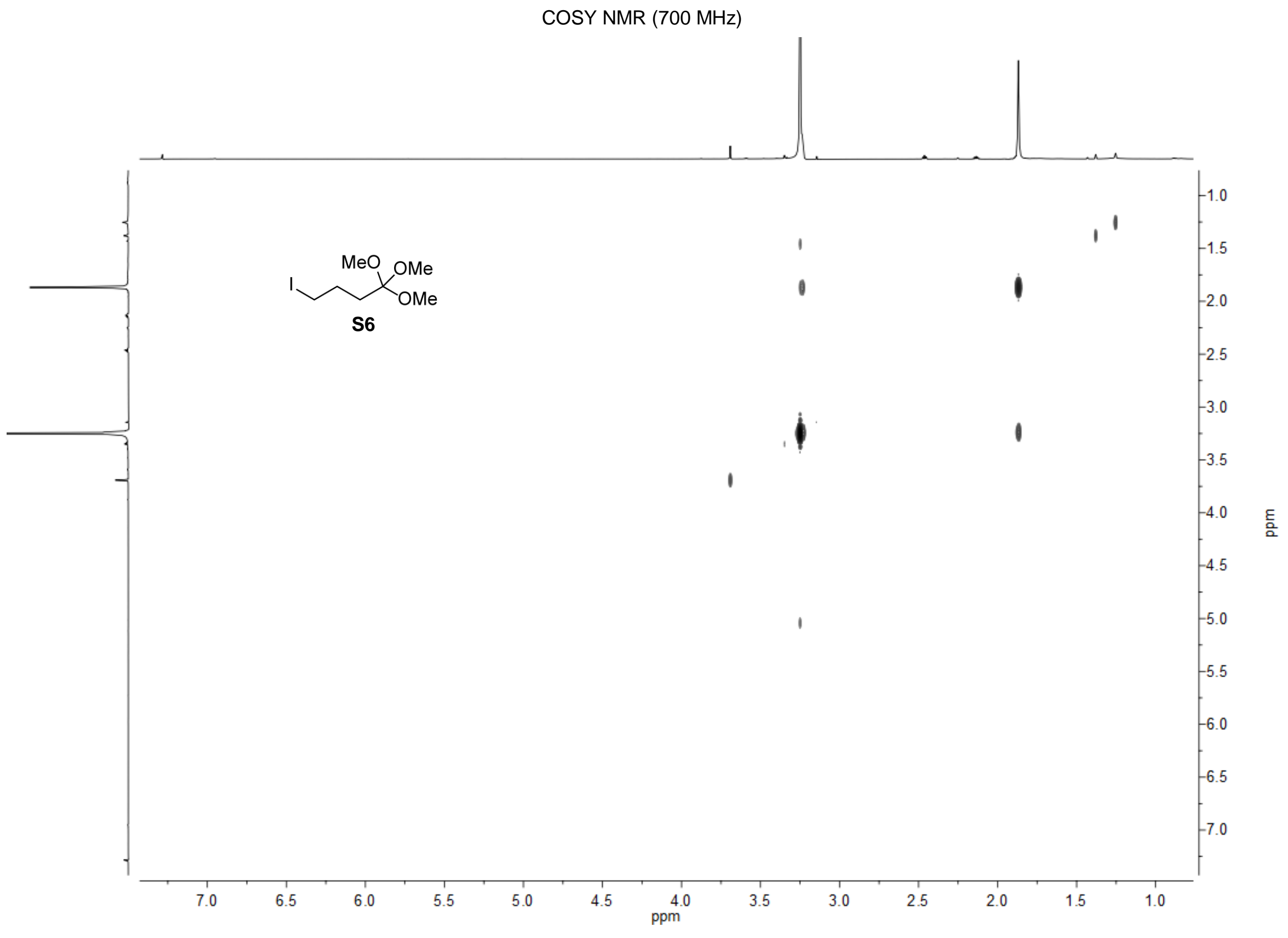

[68] 


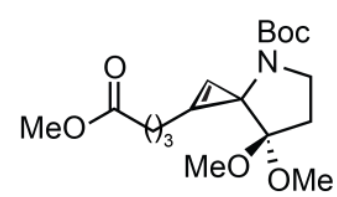

12

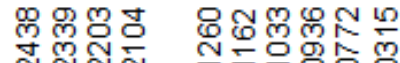

तกलฺ

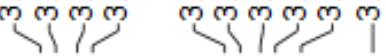

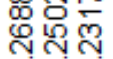

กับ

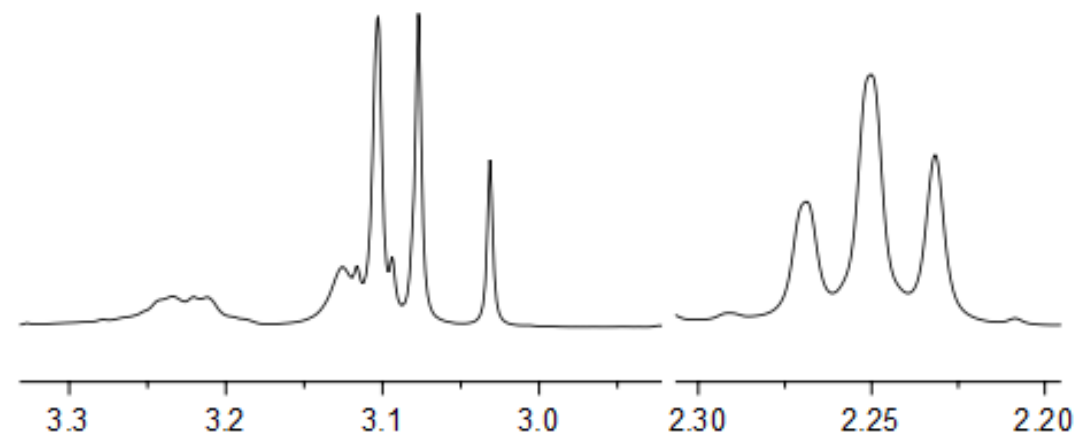

33

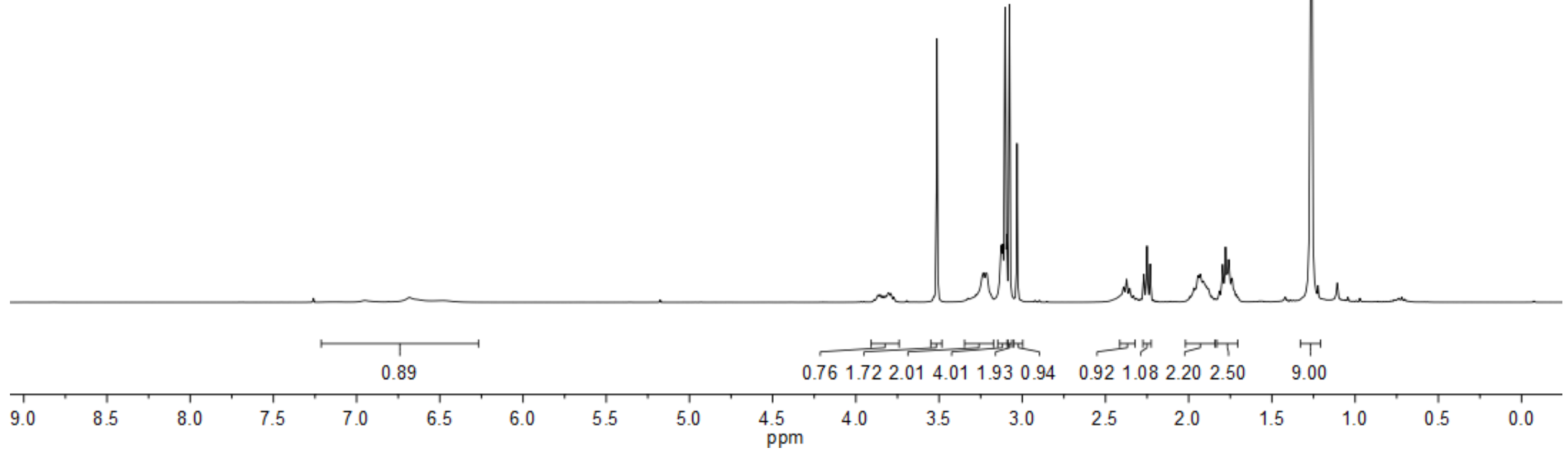


${ }^{13} \mathrm{C}$ NMR $(126 \mathrm{MHz})$
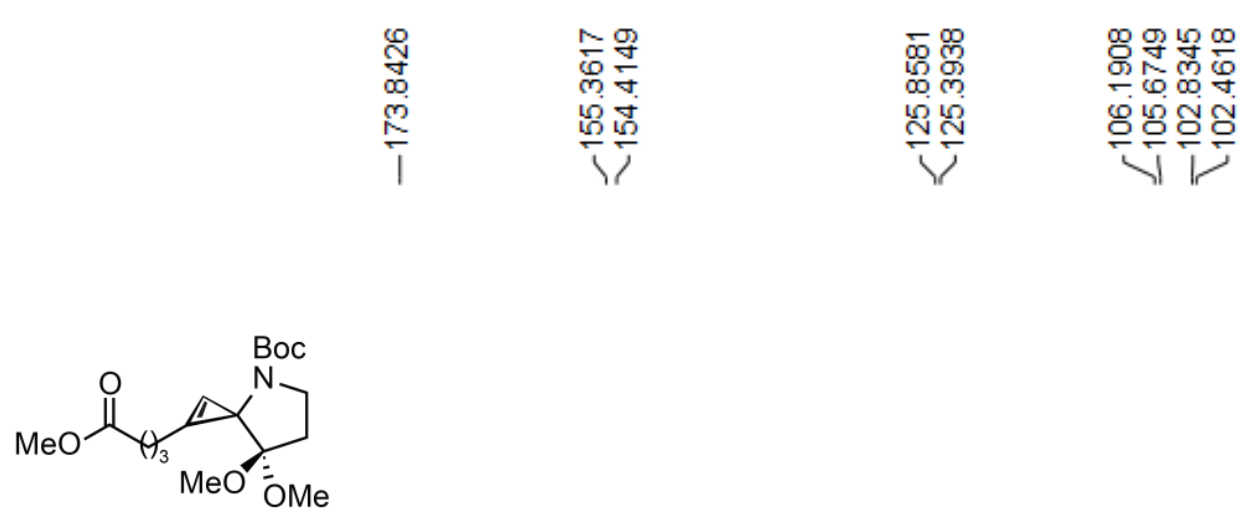

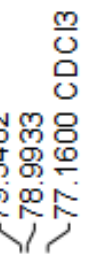

는

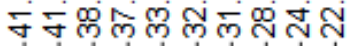

12

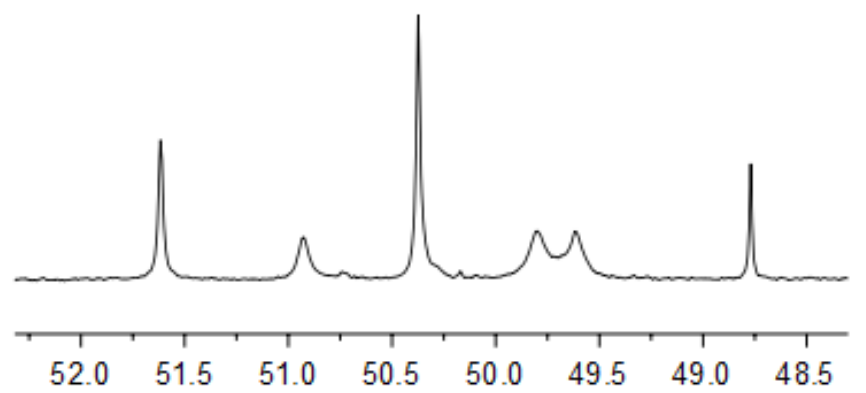


COSY NMR (400 MHz)

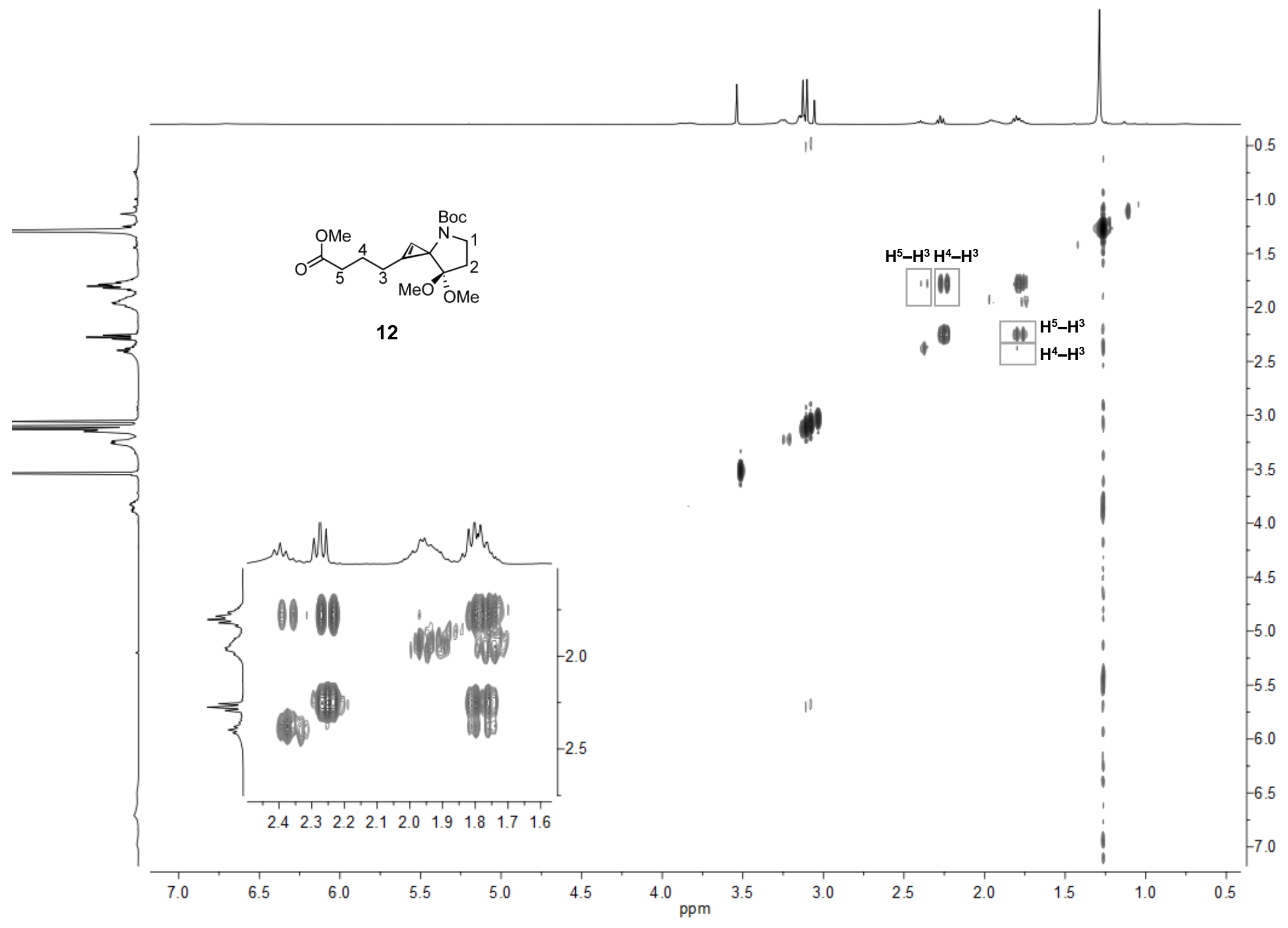


${ }^{1} \mathrm{H}$ NMR $(400 \mathrm{MHz})$
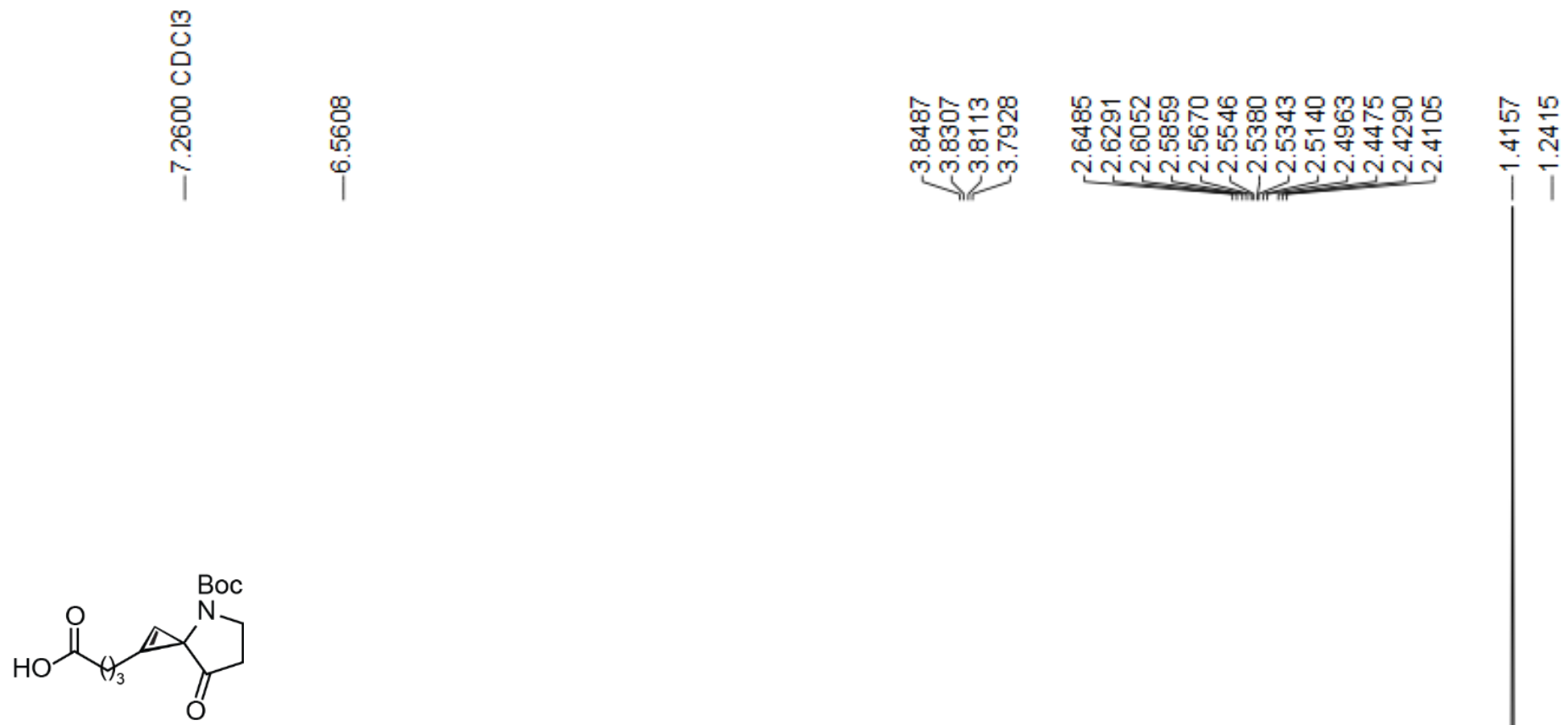

13

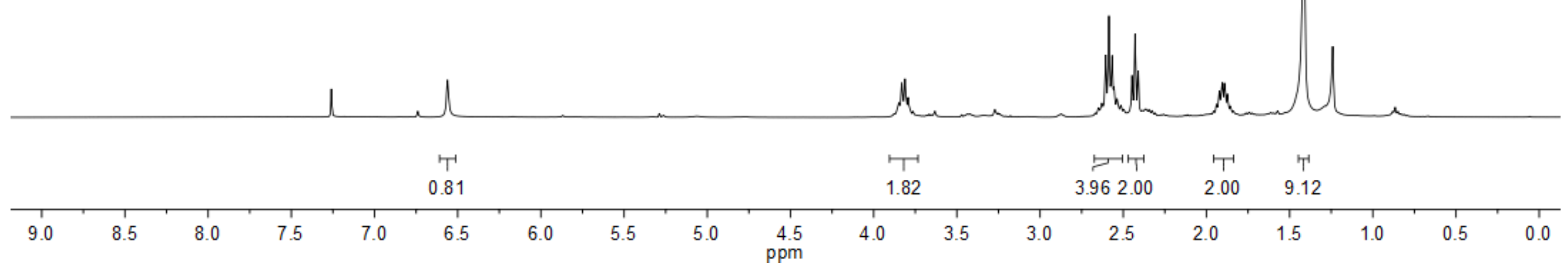


${ }^{13} \mathrm{C}$ NMR (101 MHz)
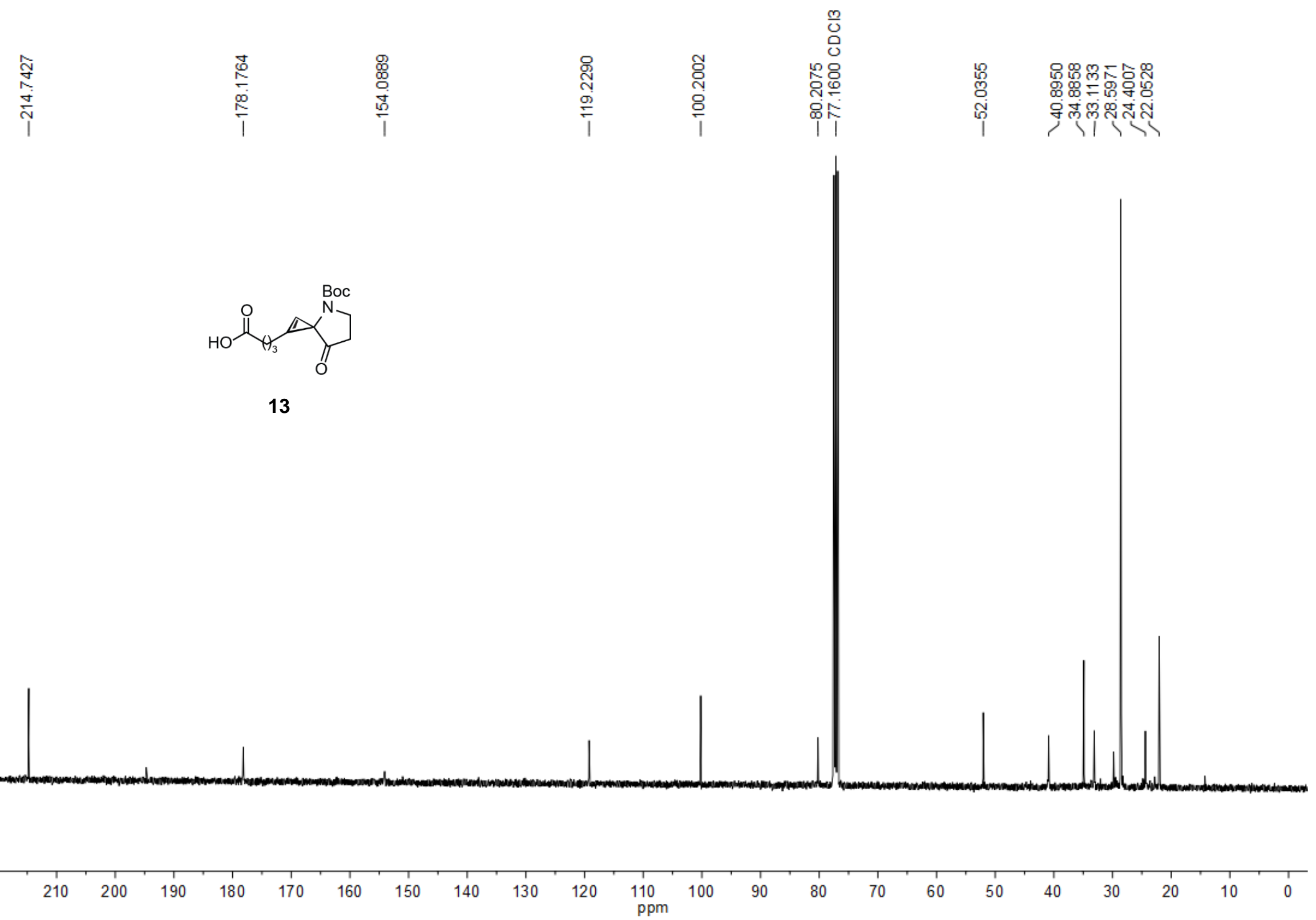

[73] 


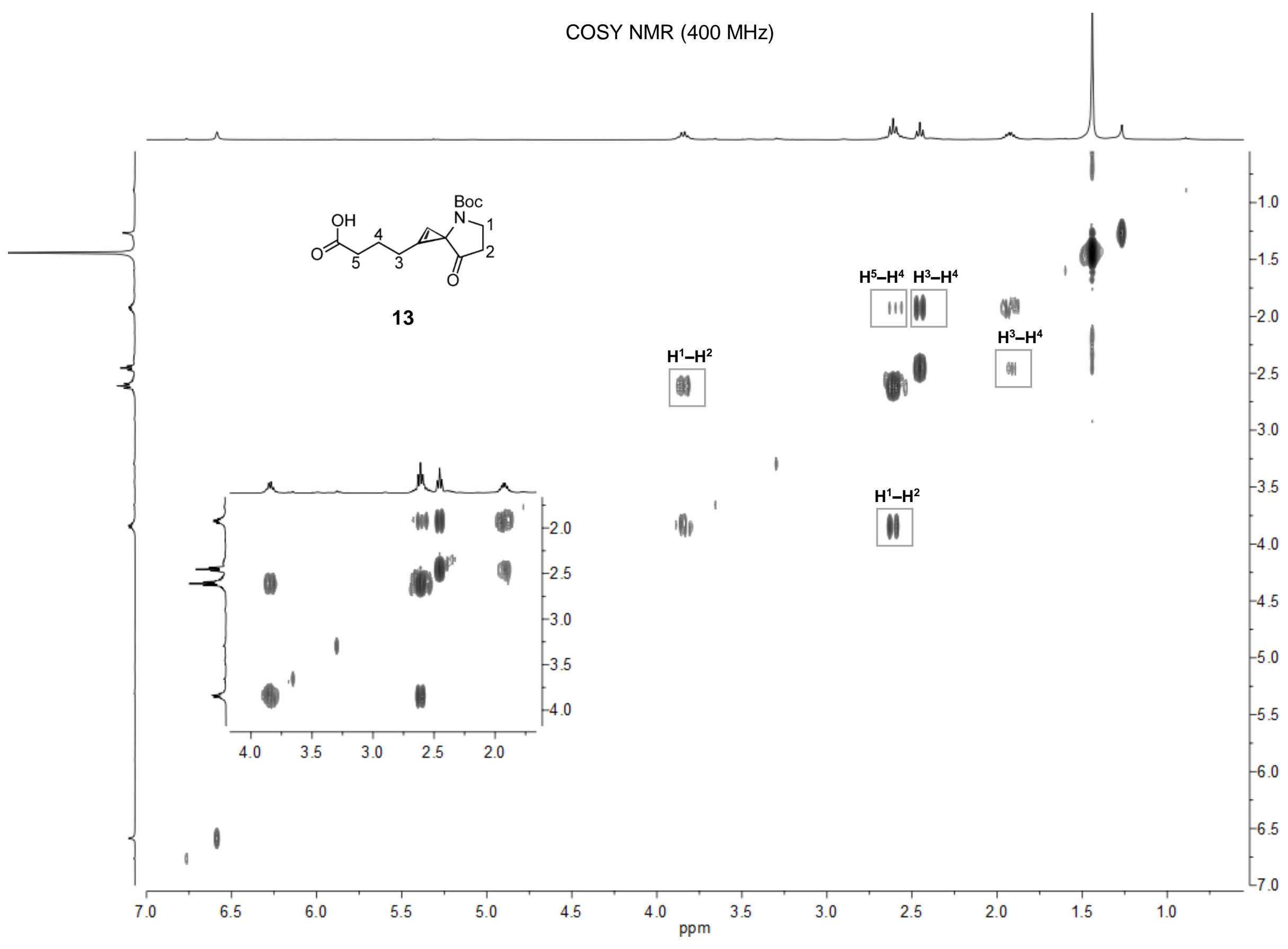




\section{Scheme S6: Synthesis procedures for $14 a-c, 15 a-c$, and 16b-c}

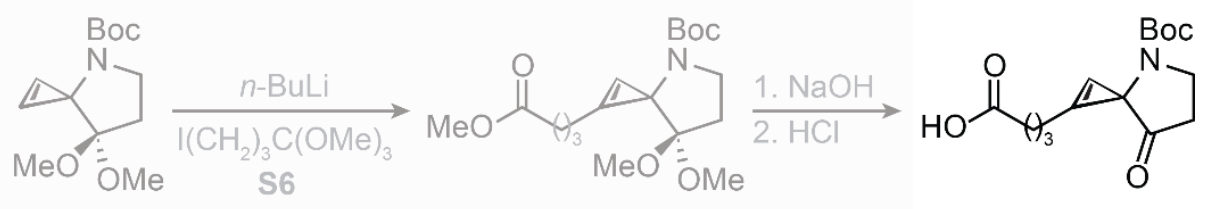

7

$12,75 \%$

$13,62 \%$

HATU

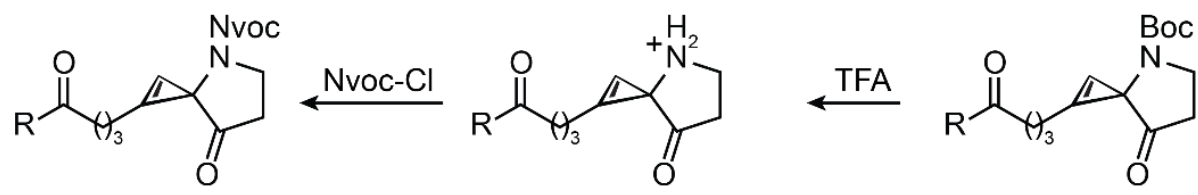

16b, $18 \%$ over two steps 16c, $76 \%$

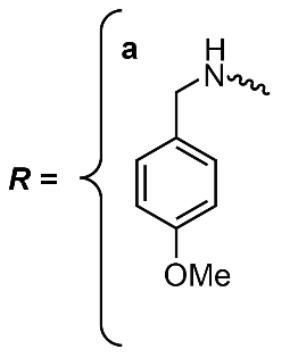

15a, $66 \%$

15b, $79 \%$

15c, $39 \%$ over two steps
$14 a, 68 \%$

14b, $54 \%$

14c, used as crude b<smiles>CNCCOCCOCCNC(=O)CCC1SCC2NC(=O)NC21</smiles><smiles></smiles><smiles>COc1ccc(CNC(=O)CC2CC23C(=O)CCN3C(=O)OC(C)(C)C)cc1</smiles>

$14 a$

To an ice-cold solution of $13(21 \mathrm{mg}, 0.071 \mathrm{mmol}, 1.0 \mathrm{eq})$ in dry DMF $(2.0 \mathrm{~mL})$ under an inert atmosphere was added DIPEA (11.04 mg, $14.87 \mathrm{uL}, 0.085 \mathrm{mmol}$, $1.2 \mathrm{eq})$. Further, HATU (32.47 $\mathrm{mg}, 0.085 \mathrm{mmol}, 1.2 \mathrm{eq}$ ) as a solution in dry DMF $(0.4 \mathrm{~mL})$ was added dropwise and the reaction was continued stirring at the same temperature for 30 mins. 4-methoxybenzylamine (11.72 $\mathrm{mg}, 0.085 \mathrm{mmol}, 1.2 \mathrm{eq})$ as a solution in dry DMF $(0.4 \mathrm{~mL})$ was added to this activated acid and the resultant yellowish mixture was allowed to gradually warm to rt overnight. The reaction mixture was extracted using DCM and water. The combined organic layer was dried over anhydrous $\mathrm{Na}_{2} \mathrm{SO}_{4}$, concentrated in vacuo, and purified by flash chromatography $(8.0 \mathrm{~g}$ silica, $30 \%-100 \%$ EtOAc/hexanes $(\mathrm{v} / \mathrm{v}))$ to obtain $14 \mathrm{a}(20 \mathrm{mg}, 68 \%)$. $R_{f}=0.22(100 \%$ EtOAc/hexanes, visualized w/ UV). ${ }^{1} \mathrm{H}$ NMR $\left(700 \mathrm{MHz}, \mathrm{CDCl}_{3}\right): \delta=7.20(\mathrm{~d}, J=8.3 \mathrm{~Hz}, 2 \mathrm{H}), 6.84(\mathrm{~d}, J=8.4 \mathrm{~Hz}, 2 \mathrm{H}), 6.53$ (s, 1H), 4.30-4.39 (m, 2H), 3.79-3.80 (s, 5H), 2.49-2.54 (m, 4H), 2.27 (t, J = 7.2 Hz, 2H), 1.96-2.02 (m, 1H), 1.89-1.93 (m, $1 \mathrm{H}), 1.40$ (s, 9H). ${ }^{13} \mathrm{C} \mathrm{NMR}\left(176 \mathrm{MHz}, \mathrm{CDCl}_{3}\right): \delta=215.21,172.34,159.02,153.92,130.87,129.27,119.49,114.09,100.67$, $80.10,55.44,52.13,43.03,40.96,35.31,34.92,28.61,24.35,23.15$. COSY NMR $\left(700 \mathrm{MHz}, \mathrm{CDCl}_{3}\right.$, attached) was obtained under the same conditions. HRMS (ESI): Calcd for $\mathrm{C}_{23} \mathrm{H}_{31} \mathrm{~N}_{2} \mathrm{O}_{5}[\mathrm{M}+\mathrm{H}]^{+}:$415.2227, found: 415.2230. 


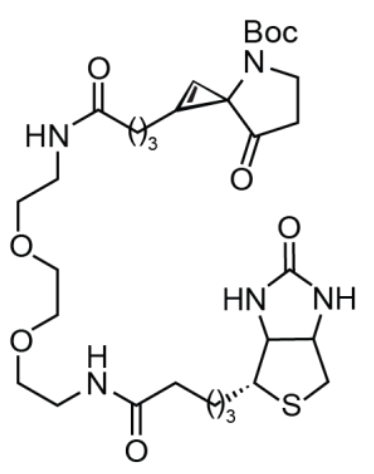

$14 b$

To an ice-cold solution of 13 (15 mg, $0.051 \mathrm{mmol}, 1.0 \mathrm{eq})$ in dry DMF (3.0 mL) under an inert atmosphere was added DIPEA $(7.9 \mathrm{mg}, 11.0 \mathrm{uL}, 0.061 \mathrm{mmol}, 1.2$ eq). Further, HATU (23.0 mg, $0.061 \mathrm{mmol}, 1.2 \mathrm{eq})$ as a solution in dry DMF (0.6 $\mathrm{mL}$ ) was added dropwise and the reaction was continued stirring at the same temperature for $30 \mathrm{mins}$. Biotin-PEG2-amine $(21.0 \mathrm{mg}, 0.056 \mathrm{mmol}, 1.1 \mathrm{eq})$ as a sonicated solution in dry DMF $(0.6 \mathrm{~mL})$ was added to this activated acid and the resultant yellowish mixture was allowed to gradually warm to rt over $48 \mathrm{~h}$. The reaction mixture was extracted using DCM and water. The combined organic layer was dried over anhydrous $\mathrm{Na}_{2} \mathrm{SO}_{4}$, concentrated in vacuo, and purified by flash chromatography (11.0 g silica, $5 \%-10 \% \mathrm{MeOH} / \mathrm{DCM}(\mathrm{v} / \mathrm{v})$ ) to obtain $14 \mathrm{~b}$ (18 mg, $54 \%) . R_{f}=0.24\left(10 \% \mathrm{MeOH} / \mathrm{DCM}\right.$, visualized w/ UV). ${ }^{1} \mathrm{H}$ NMR $\left(400 \mathrm{MHz}, \mathrm{CDCl}_{3}\right): \delta=6.61-6.59(\mathrm{~m}, 2 \mathrm{H}), 6.56-6.53(\mathrm{~m}$, $1 \mathrm{H}), 6.20(\mathrm{br} \mathrm{s}, 1 \mathrm{H}), 5.33(\mathrm{~s}, 1 \mathrm{H}), 4.50(\mathrm{dd}, J=7.8,4.9 \mathrm{~Hz}, 1 \mathrm{H}), 4.31(\mathrm{dd}, J=8.2,4.7 \mathrm{~Hz}, 1 \mathrm{H}), 3.83(\mathrm{t}, J=7.7 \mathrm{~Hz}, 1.5 \mathrm{H})$, $3.61(\mathrm{~s}, 4 \mathrm{H}), 3.57-3.54(\mathrm{~m}, 3.5 \mathrm{H}), 3.43(\mathrm{t}, J=5.9 \mathrm{~Hz}, 4 \mathrm{H}), 3.15(\mathrm{td}, J=7.4,4.5 \mathrm{~Hz}, 1 \mathrm{H}), 2.91(\mathrm{dd}, J=12.8,4.9 \mathrm{~Hz}, 1 \mathrm{H})$, $2.74(\mathrm{~d}, J=12.8 \mathrm{~Hz}, 1 \mathrm{H}), 2.61-2.54(\mathrm{~m}, 3 \mathrm{H}), 2.28-2.21(\mathrm{~m}, 4 \mathrm{H}), 1.97-1.84(\mathrm{~m}, 3 \mathrm{H}), 1.72-1.66(\mathrm{~m}, 4 \mathrm{H}), 1.50-1.44(\mathrm{~m}, 3 \mathrm{H})$, $1.42(\mathrm{~s}, 9 \mathrm{H}) .{ }^{13} \mathrm{C}$ NMR $\left(101 \mathrm{MHz}, \mathrm{CDCl}_{3}\right): \delta=215.23,173.36,172.85,172.81,163.82,119.60,100.34,80.08,70.24,70.20$, $70.03,69.97,61.86,60.33,55.55,52.15,40.63,39.28,39.26,36.10,35.40,34.99,28.66,28.21,25.63,24.52,23.08$. COSY NMR (400 MHz, $\mathrm{CDCl}_{3}$, attached) was obtained under the same conditions. HRMS (ESI): Calcd for $\mathrm{C}_{31} \mathrm{H}_{49} \mathrm{~N}_{5} \mathrm{O}_{8} \mathrm{SNa}$ $[\mathrm{M}+\mathrm{Na}]^{+}: 674.3194$, found: 674.3193 .

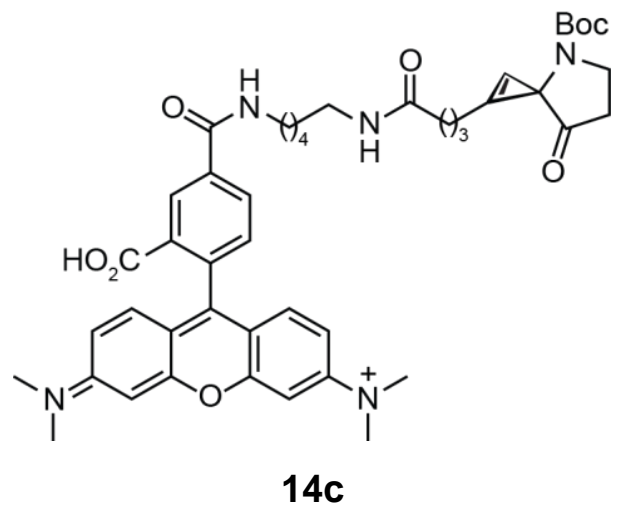

To an ice-cold solution of $\mathbf{1 3}(6.16 \mathrm{mg}, 0.021 \mathrm{mmol}, 1.3 \mathrm{eq})$ in dry DMF (1.7 $\mathrm{mL}$ ) under an inert atmosphere was added DIPEA $(2.7 \mathrm{mg}, 4.47 \mathrm{uL}, 0.021$ $\mathrm{mmol}, 1.44 \mathrm{eq})$. Further, HATU $(9.5 \mathrm{mg}, 0.025 \mathrm{mmol}, 1.57 \mathrm{eq})$ as a solution in dry DMF $(0.5 \mathrm{~mL})$ was added dropwise and the reaction was continued stirring at the same temperature for 30 mins. TAMRA-amine $(10.07 \mathrm{mg}, 0.016$ $\mathrm{mmol}, 1.0 \mathrm{eq})$ as a solution in dry DMF $(0.4 \mathrm{~mL})$ was added to this activated acid and the resultant pink mixture was allowed to gradually warm to rt over $30 \mathrm{~h}$. The reaction mixture was extracted using $\mathrm{DCM}$ and $2 \mathrm{M} \mathrm{HCl}$. The combined organic layer was dried over anhydrous $\mathrm{Na}_{2} \mathrm{SO}_{4}$, concentrated in vacuo, and used directly without further purification to obtain crude $14 \mathrm{c}$. MS

(ESI): Calcd for $\mathrm{C}_{45} \mathrm{H}_{54} \mathrm{~N}_{5} \mathrm{O}_{8}[\mathrm{M}]^{+}:$792.4, found: 792.4, $405.3\left[\mathrm{M}+\mathrm{NH}_{4}\right]^{2+}$.

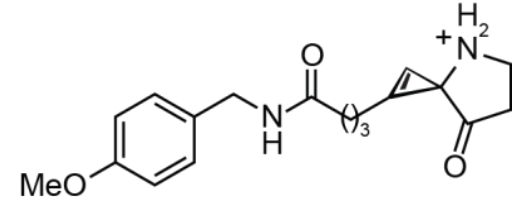

$15 a$

To an ice-cold solution of 14a (14.2 $\mathrm{mg}, 0.024 \mathrm{mmol})$ in DCM $(2.0 \mathrm{~mL})$ was added TFA $(0.5 \mathrm{~mL})$. The reaction was allowed to gradually warm to rt over $2 \mathrm{~h}$. The reaction was concentrated in vacuo, re-suspended in $\mathrm{MeOH} / \mathrm{H}_{2} \mathrm{O}$, and purified by HPLC $\left(\mathrm{R}_{\mathrm{t}}=13.09 \mathrm{~min}, 100 \% \mathrm{H}_{2} \mathrm{O}+0.1 \%\right.$ TFA 0-5 mins then $20-100 \% \mathrm{MeOH} / \mathrm{H}_{2} \mathrm{O}$ $+0.1 \%$ TFA over $30 \mathrm{mins}$, flow rate $=20 \mathrm{~mL} / \mathrm{min})$ to obtain $15 \mathrm{a}(9.7 \mathrm{mg}, 66.2 \%)$ as a TFA salt. ${ }^{1} \mathrm{H}$ NMR $\left(500 \mathrm{MHz}, \mathrm{CDCl}_{3}\right): \delta=7.16(\mathrm{~d}, \mathrm{~J}=8.3 \mathrm{~Hz}, 2 \mathrm{H}), 6.85(\mathrm{~d}, \mathrm{~J}=8.3$ $\mathrm{Hz}, 2 \mathrm{H}), 6.63(\mathrm{~s}, 1 \mathrm{H}), 6.46(\mathrm{t}, \mathrm{J}=5.6 \mathrm{~Hz}, 1 \mathrm{H}), 4.30(\mathrm{~d}, \mathrm{~J}=5.2 \mathrm{~Hz}, 2 \mathrm{H}), 3.78(\mathrm{~s}, 3 \mathrm{H}), 3.76-3.64(\mathrm{~m}, 2 \mathrm{H}), 2.73-2.82(\mathrm{~m}, 2 \mathrm{H})$, 2.54-2.67 (m, 2H), 2.21-2.32 (m, 2H), 1.89-1.98 (m, 2H). ${ }^{13} \mathrm{C} \mathrm{NMR} \mathrm{(126} \mathrm{MHz,} \mathrm{CDCl} 3$ ): $\delta=207.88,159.31,129.78,129.27$, $116.61,114.31,98.72,55.46,50.69,43.42,39.43,34.94,34.34,23.18,22.49$. COSY NMR $\left(500 \mathrm{MHz}, \mathrm{CDCl}_{3}\right.$, attached) was obtained under the same conditions. HRMS (ESI): Calcd for $\mathrm{C}_{18} \mathrm{H}_{23} \mathrm{~N}_{2} \mathrm{O}_{3}[\mathrm{M}]^{+}:$315.1703, found: 315.1704 . 


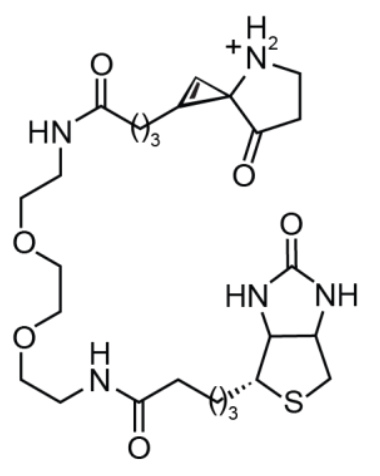

$15 b$

To an ice-cold solution of $14 \mathbf{b}(9 \mathrm{mg}, 0.014 \mathrm{mmol})$ in DCM $(3.0 \mathrm{~mL})$ was added TFA $(0.6 \mathrm{~mL})$. The reaction was allowed to gradually warm to $\mathrm{rt}$ over $1 \mathrm{~h}$. The reaction was concentrated in vacuo, re-suspended in $\mathrm{MeOH}$, and purified by HPLC to obtain 15b (6.0 mg, 79\%) as a TFA salt. ${ }^{1} \mathrm{H}$ NMR $\left(500 \mathrm{MHz}, \mathrm{CD}_{3} \mathrm{OD}\right): \delta=7.05(\mathrm{~s}, 1 \mathrm{H})$, 4.50 (dd, $J=7.9,4.9 \mathrm{~Hz}, 1 \mathrm{H}$ ), 4.31 (dd, $J=7.9,4.5 \mathrm{~Hz}, 1 \mathrm{H}$ ), 3.77 (t, $J=8.0 \mathrm{~Hz}$, $1 \mathrm{H}), 3.62(\mathrm{~s}, 4 \mathrm{H}), 3.55(\mathrm{td}, J=5.5,1.9 \mathrm{~Hz}, 4 \mathrm{H}), 3.37(\mathrm{q}, J=5.4 \mathrm{~Hz}, 4 \mathrm{H}), 3.24-3.19$ $(\mathrm{m}, 1 \mathrm{H}), 2.93(\mathrm{dd}, J=12.7,5.0 \mathrm{~Hz}, 1 \mathrm{H}), 2.79(\mathrm{dt}, J=8.0,4.1 \mathrm{~Hz}, 1 \mathrm{H}), 2.81-2.77$ (m, 2H), 2.61-2.55 (m, 1H), $2.31(\mathrm{td}, J=7.3,3.1 \mathrm{~Hz}, 1.5 \mathrm{H}), 2.22(\mathrm{t}, J=7.4 \mathrm{~Hz}, 2 \mathrm{H})$, 1.99-1.85 (m, 3.5H), 1.78-1.56 (m, 5H), 1.45 (q, J = $7.6 \mathrm{~Hz}, 2 \mathrm{H}), 1.38-1.36(\mathrm{~m}$, 1H). ${ }^{13} \mathrm{C} \mathrm{NMR}\left(126 \mathrm{MHz}, \mathrm{CD}_{3} \mathrm{OD}\right): 208.92,176.19,175.14,166.11,161.40,161.10$, $160.80,160.50,118.61,99.27,71.30,70.59,70.55,63.39,61.65,57.03,41.05,40.66,40.35,40.28,36.75,35.61,34.94$, 29.76, 29.52, 26.88, 24.04, 23.81. HRMS (ESI): Calcd for $\mathrm{C}_{26} \mathrm{H}_{41} \mathrm{~N}_{5} \mathrm{O}_{6} \mathrm{~S}[\mathrm{M}+\mathrm{H}]^{+}$: 552.2850, found: 552.2846.

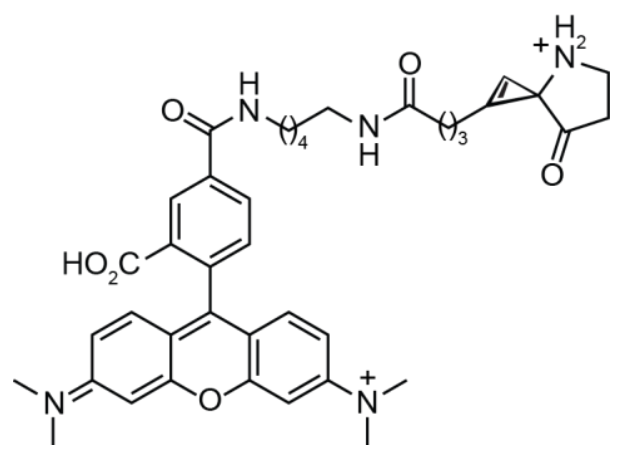

$15 c$

To an ice-cold solution of crude 14c obtained from the previous step in DCM $(3.0 \mathrm{~mL})$ was added TFA $(0.6 \mathrm{~mL})$. The reaction was allowed to gradually warm to rt over $1 \mathrm{~h}$. The reaction was concentrated in vacuo, re-suspended in $40 \% \mathrm{MeCN} / \mathrm{H}_{2} \mathrm{O}(1.0 \mathrm{~mL})$, and purified by using an analytical column on HPLC (25-100\% MeCN+0.1\% TFA over 25 mins, flow rate $=1 \mathrm{~mL} / \mathrm{min})$ to obtain $15 \mathrm{c}$ ( $6.5 \mathrm{mg}, 38.6 \%$ over two steps) as a TFA salt. ${ }^{1} \mathrm{H}$ NMR $(700 \mathrm{MHz}$, $\left.\mathrm{CD}_{3} \mathrm{OD}\right): \delta=8.77(\mathrm{~d}, J=1.8 \mathrm{~Hz}, 1 \mathrm{H}), 8.26(\mathrm{dd}, J=7.9,1.8 \mathrm{~Hz}, 1.5 \mathrm{H}), 7.54$ $(\mathrm{d}, J=7.9 \mathrm{~Hz}, 1.5 \mathrm{H}), 7.14(\mathrm{~d}, J=9.4 \mathrm{~Hz}, 2 \mathrm{H}), 7.07(\mathrm{dd}, J=9.4,2.3 \mathrm{~Hz}, 2.4 \mathrm{H})$, $7.00(\mathrm{~d}, J=2.4 \mathrm{~Hz}, 1.6 \mathrm{H}), 3.78(\mathrm{t}, J=8.0 \mathrm{~Hz}, 1 \mathrm{H}), 3.47(\mathrm{t}, J=7.2 \mathrm{~Hz}, 1.5 \mathrm{H})$, $3.32(\mathrm{~s}, 12 \mathrm{H}), 3.20-3.24(\mathrm{~m}, 2 \mathrm{H}), 2.79(\mathrm{td}, J=8.0,4.2 \mathrm{~Hz}, 1 \mathrm{H}), 2.67-2.70(\mathrm{~m}$, $1 \mathrm{H}), 2.57-2.60(\mathrm{~m}, 1 \mathrm{H}), 2.26-2.33(\mathrm{~m}, 3.5 \mathrm{H}), 1.87-1.96(\mathrm{~m}, 3 \mathrm{H}), 1.71(\mathrm{q}, J=7.6 \mathrm{~Hz}, 2 \mathrm{H}), 1.60(\mathrm{q}, J=7.4 \mathrm{~Hz}, 2 \mathrm{H}), 1.48-$ $1.45(\mathrm{~m}, 2 \mathrm{H}) .{ }^{13} \mathrm{C}$ NMR $\left(176 \mathrm{MHz}, \mathrm{CD}_{3} \mathrm{OD}\right): \delta=208.82,174.95,168.14,167.33,161.48,160.68,159.08,159.00,138.08$, 137.81, 132.88, 132.24, 131.92, 131.26, 115.57, 114.73, 99.25, 97.47, 52.07, 41.11, 40.93, 40.67, 40.33, 35.66, 34.92, 30.18, 30.11, 25.40, 24.06, 23.88. HRMS (ESI): Calcd for $\mathrm{C}_{40} \mathrm{H}_{46} \mathrm{~N}_{5} \mathrm{O}_{6}$ [M] : 692.3448 , found: 692.3444 .

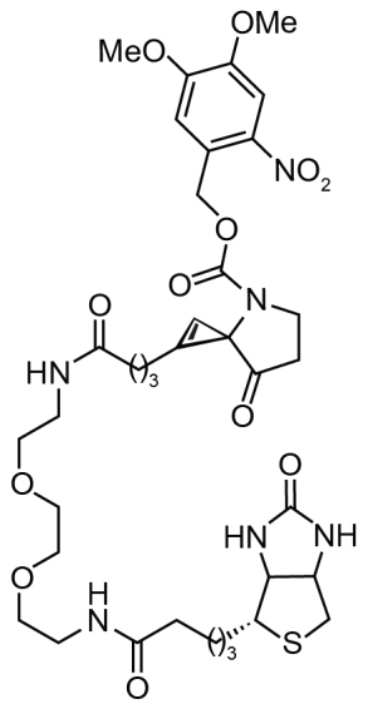

$16 b$
To an ice-cold suspension of crude 15b $(\sim 9.0 \mathrm{mg})$ obtained after TFA deprotection (started from $9 \mathrm{mg}$ of 14b) in $\mathrm{MeCN}(3.0 \mathrm{~mL})$ and water $(2.0 \mathrm{~mL})$ was added solid $\mathrm{NaHCO}_{3}(\mathrm{pH} \sim 8.5)$. To this reaction mixture was added Nvoc-Cl (5.39 mg, $0.02 \mathrm{mmol}, 1.2 \mathrm{eq})$ and the dark orange reaction mixture was allowed to warm up to rt over $40 \mathrm{~h}$ under dark. The reaction was diluted with DCM and water and the combined organic layer was dried over anhydrous $\mathrm{Na}_{2} \mathrm{SO}_{4}$, concentrated in vacuo, re-suspended in $\mathrm{MeCN}$, filtered through a $0.45 \mu \mathrm{m}$ filter, and purified over silica gel to obtain $16 \mathrm{~b}(2.1 \mathrm{mg}$, $18 \%$ over two steps). $R_{f}=0.25(15 \% \mathrm{MeOH} / \mathrm{DCM}$, visualized w/ UV). Due to low amount of this molecule we could not obtain satisfactory NMRs. HRMS (ESI): Calcd for $\mathrm{C}_{36} \mathrm{H}_{50} \mathrm{~N}_{6} \mathrm{O}_{12} \mathrm{SNa}[\mathrm{M}+\mathrm{Na}]^{+}$: 813.3100, found: 813.3105. 


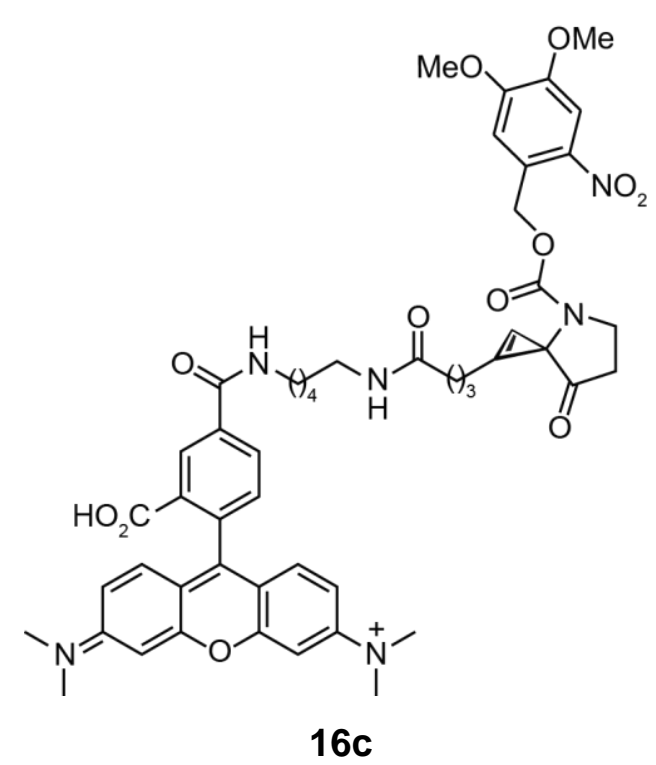

To an ice-cold suspension of $15 \mathrm{c}(2.2 \mathrm{mg}, 0.003,1.0 \mathrm{eq})$ in $\mathrm{MeCN}(1.5 \mathrm{~mL})$ and water $(1.0 \mathrm{~mL})$ was added solid $\mathrm{NaHCO}_{3}(\mathrm{pH} \sim 8.5)$. To this reaction mixture was added Nvoc-Cl $(2.0 \mathrm{mg}, 0.006 \mathrm{mmol}, 2.0 \mathrm{eq})$ and the reaction was allowed to warm up to rt over $48 \mathrm{~h}$ under dark. The reaction was stopped based on MS, filtered through a $0.45 \mu \mathrm{m}$ filter, and purified by HPLC $\left(R_{t}=\right.$ $16.3 \mathrm{mins}, 40-100 \% \mathrm{MeCN}+0.1 \%$ TFA over $25 \mathrm{mins}$, flow rate $=1 \mathrm{~mL} / \mathrm{min}$ ) to obtain 16c (2.2 mg, 76\%). ${ }^{1} \mathrm{H}$ NMR (700 MHz, $\left.\mathrm{CD}_{3} \mathrm{OD}\right): \delta=8.76(\mathrm{~d}, \mathrm{~J}=$ $4.7 \mathrm{~Hz}, 1 \mathrm{H}), 8.26-8.25(\mathrm{~m}, 1 \mathrm{H}), 7.72-7.71(\mathrm{~m}, 1 \mathrm{H}), 7.53(\mathrm{~d}, J=7.7 \mathrm{~Hz}, 1 \mathrm{H})$, 7.15-7.13 (m, 2H), 7.10-7.03 (m, 2H), 7.01-6.94 (m, 2H), $6.77(\mathrm{~s}, 1 \mathrm{H}), 5.49$ $(\mathrm{s}, 2 \mathrm{H}), 3.94-3.89(\mathrm{~m}, 6 \mathrm{H}), 3.49-3.46(\mathrm{~m}, 2 \mathrm{H}), 3.35(2 \times \mathrm{s}, 12 \mathrm{H}), 3.22-3.19$ (m, 2H), 2.69 (ddd, $J=17.1,9.4,6.9 \mathrm{~Hz}, 1 \mathrm{H}$ ), 2.62 (ddd, $J=18.5,9.0,5.2$ $\mathrm{Hz}, 1 \mathrm{H}), 2.51-2.36(\mathrm{~m}, 2 \mathrm{H}), 2.29-2.19(\mathrm{~m}, 2.5 \mathrm{H}), 1.87-1.80(\mathrm{~m}, 2 \mathrm{H}), 1.71-$ $1.69(\mathrm{~m}, 2 \mathrm{H}), 1.60-1.57(\mathrm{~m}, 2.5 \mathrm{H}), 1.46-1.45(\mathrm{~m}, 2 \mathrm{H}) .{ }^{13} \mathrm{C} \mathrm{NMR}(176 \mathrm{MHz}$, $\left.\mathrm{CDCl}_{3}\right): \delta=157.69,157.37,135.77,131.88,131.49,130.09,116.52,114.40$, 113.90, 108.38, 96.51, 56.57, 40.96, 40.08, 39.48, 35.10, 32.08, 29.86, 24.01, 23.16, 22.85, 14.29. Peaks for some quaternary carbons were not observed. HRMS (ESI): Calcd for $\mathrm{C}_{50} \mathrm{H}_{55} \mathrm{~N}_{6} \mathrm{O}_{12}$ [M] $]^{+}: 931.3878$, found: 931.3880 . 
${ }^{1} \mathrm{H} \mathrm{NMR}(700 \mathrm{MHz})$

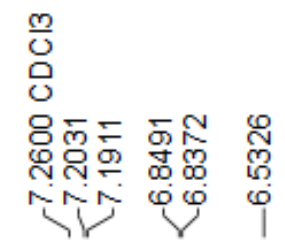

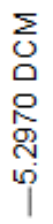

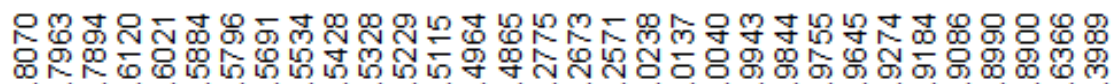

ळ.

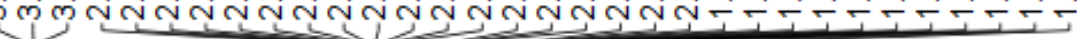

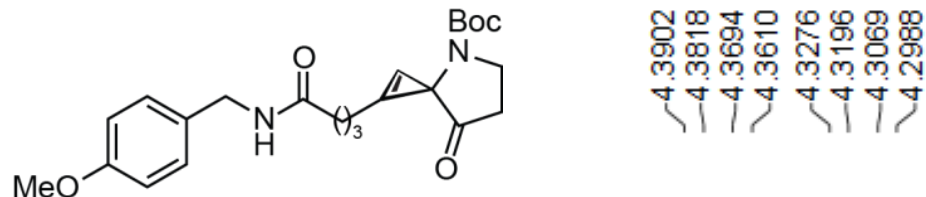

$14 a$
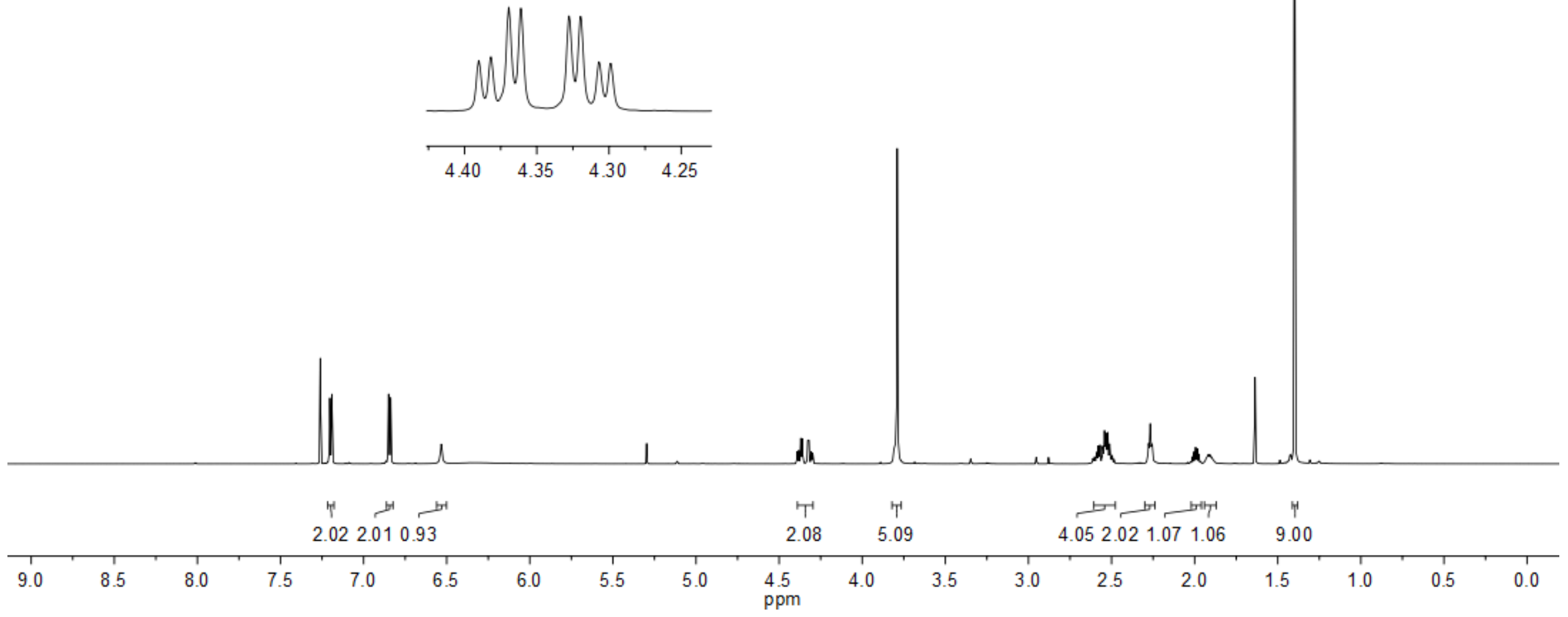

[79] 
${ }^{13} \mathrm{C}$ NMR (176 MHz)

ֶָ.

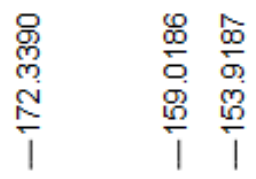

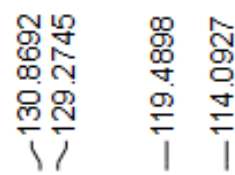

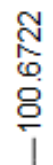

№

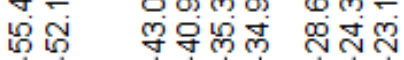

多

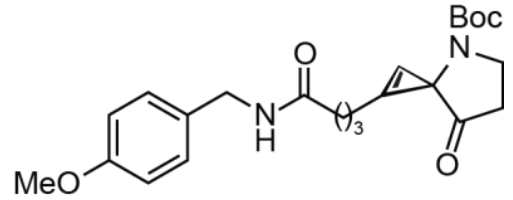

$14 a$ 


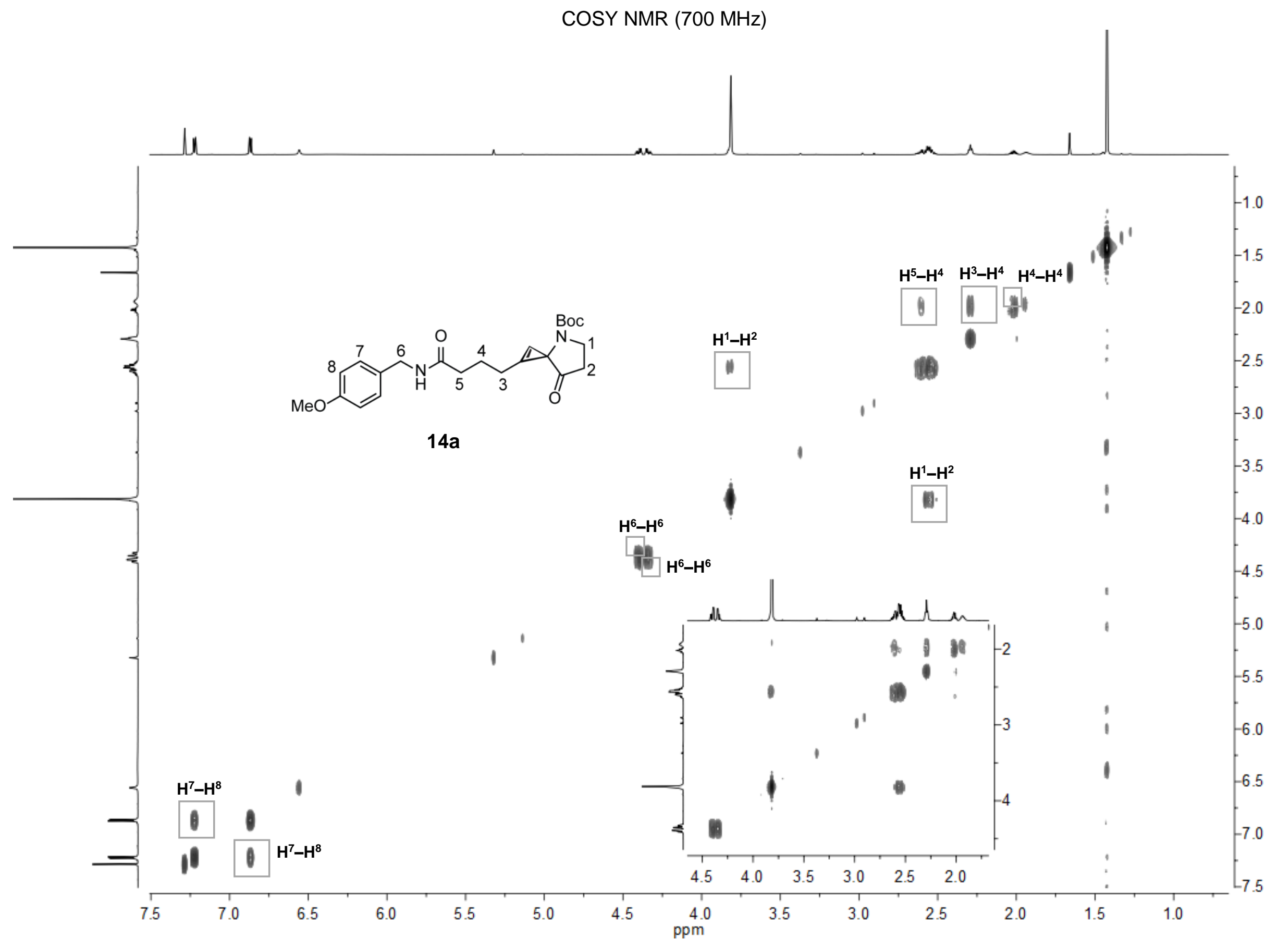


${ }^{1} \mathrm{H}$ NMR $(400 \mathrm{MHz})$

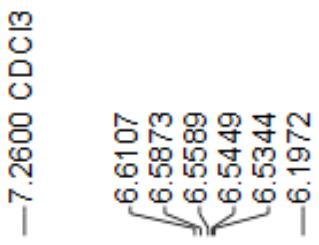

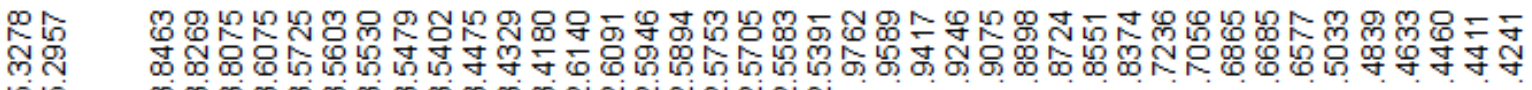

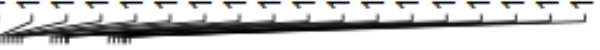

$14 b$

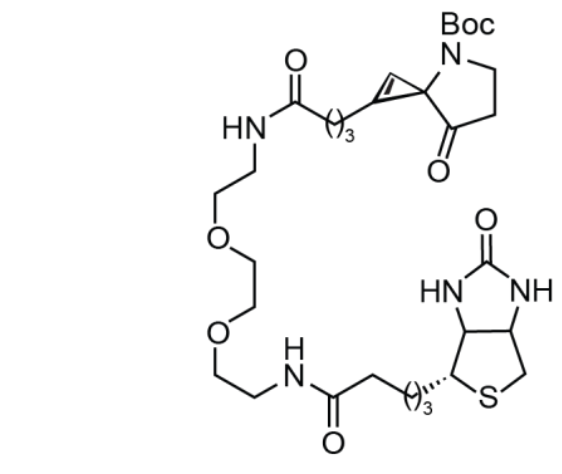

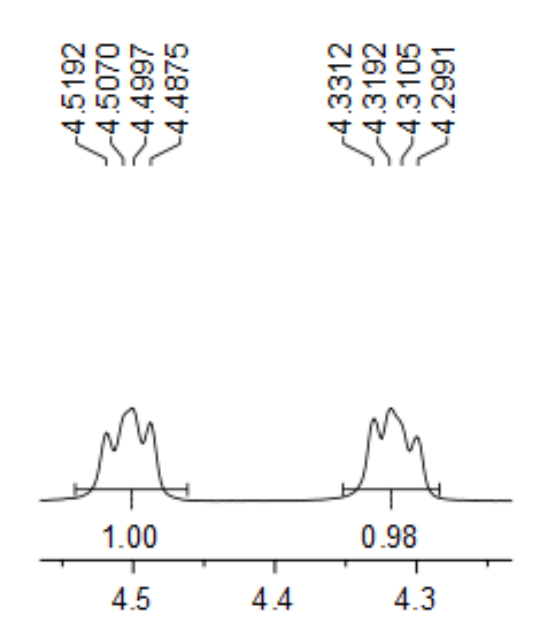
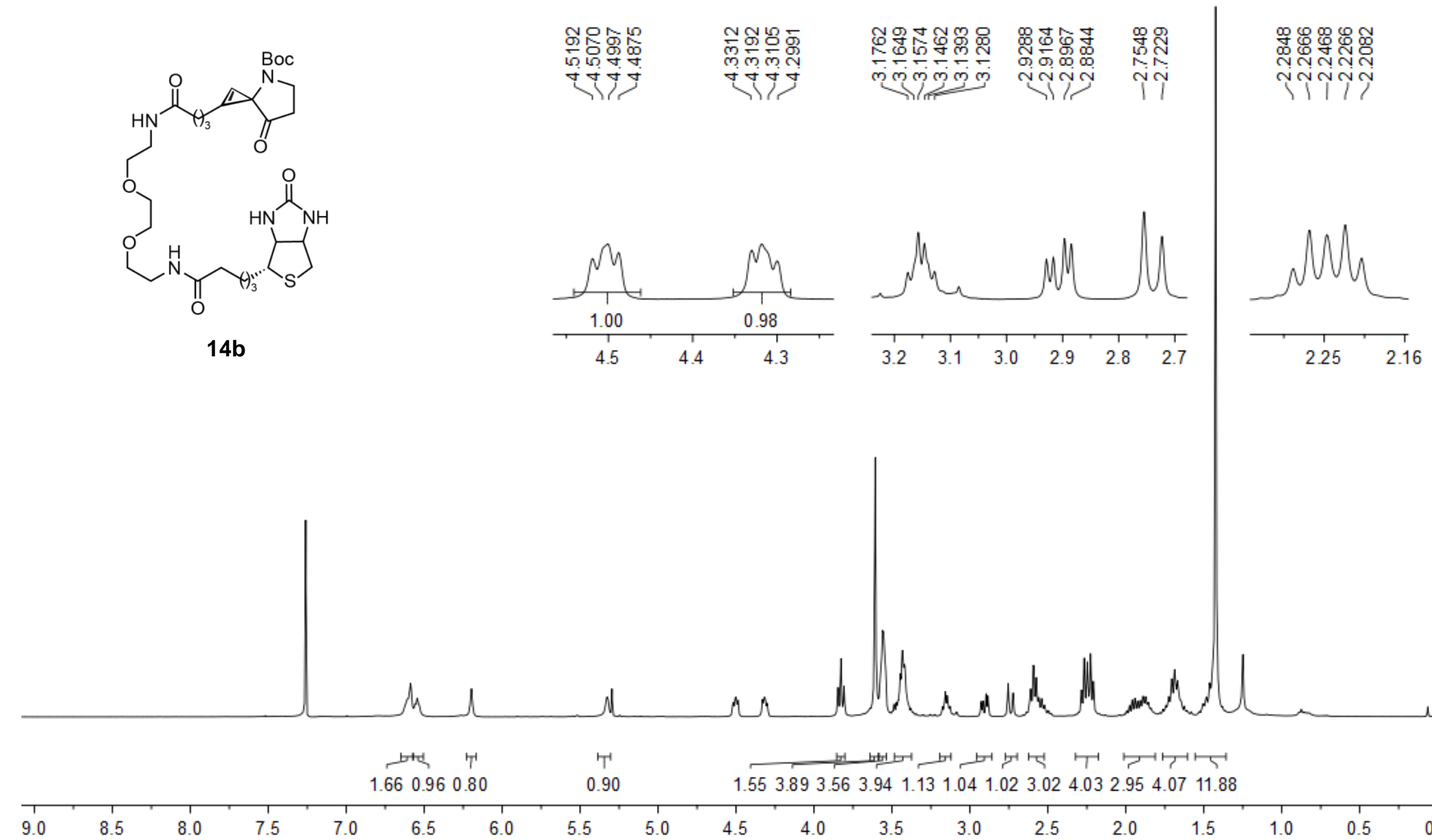

trted T

1.660 .960 .80

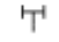

0.90 $\begin{array}{lllll}1.553 .89 & 3.563 .941 .131 .041 .023 .024 .032 .954 .07 & 11.88\end{array}$

6.5

$6.0 \quad 5$

15

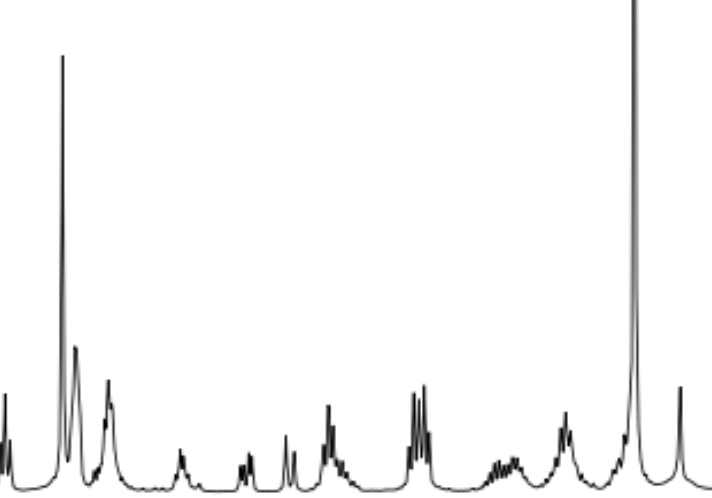

1


${ }^{13} \mathrm{C}$ NMR $(101 \mathrm{MHz})$

ํㅠำ

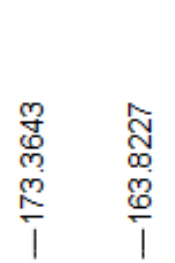

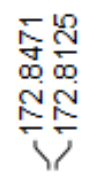

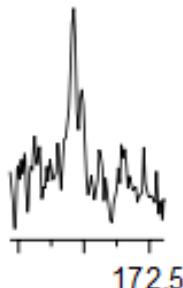

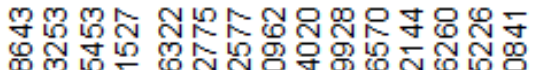
๓ फ

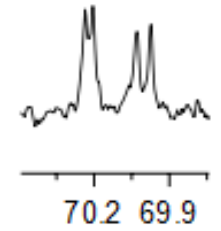

$\stackrel{5}{0}$
$\stackrel{0}{\circ}$

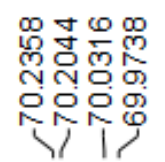

\begin{tabular}{l}
$\$$ \\
$\$$ \\
2 \\
\hdashline \\
0 \\
0 \\
1
\end{tabular} î

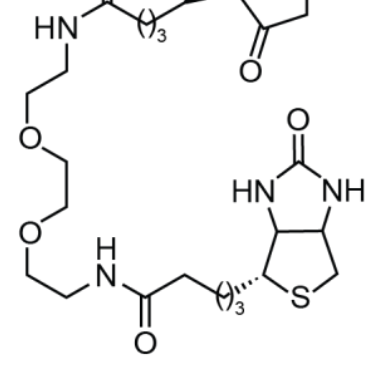

$14 b$

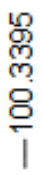

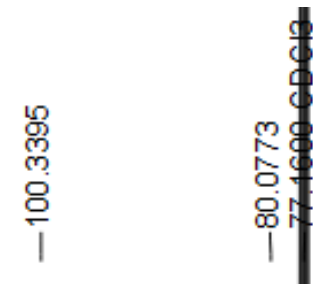

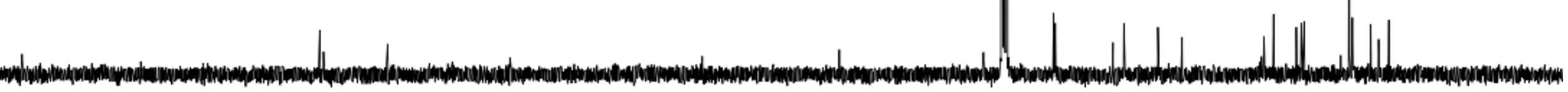

$\begin{array}{lllllllllll}210 & 200 & 190 & 180 & 170 & 160 & 150 & 140 & 130 & 120 & \begin{array}{l}110 \\ \mathrm{ppm}\end{array}\end{array}$


COSY NMR (400 MHz)

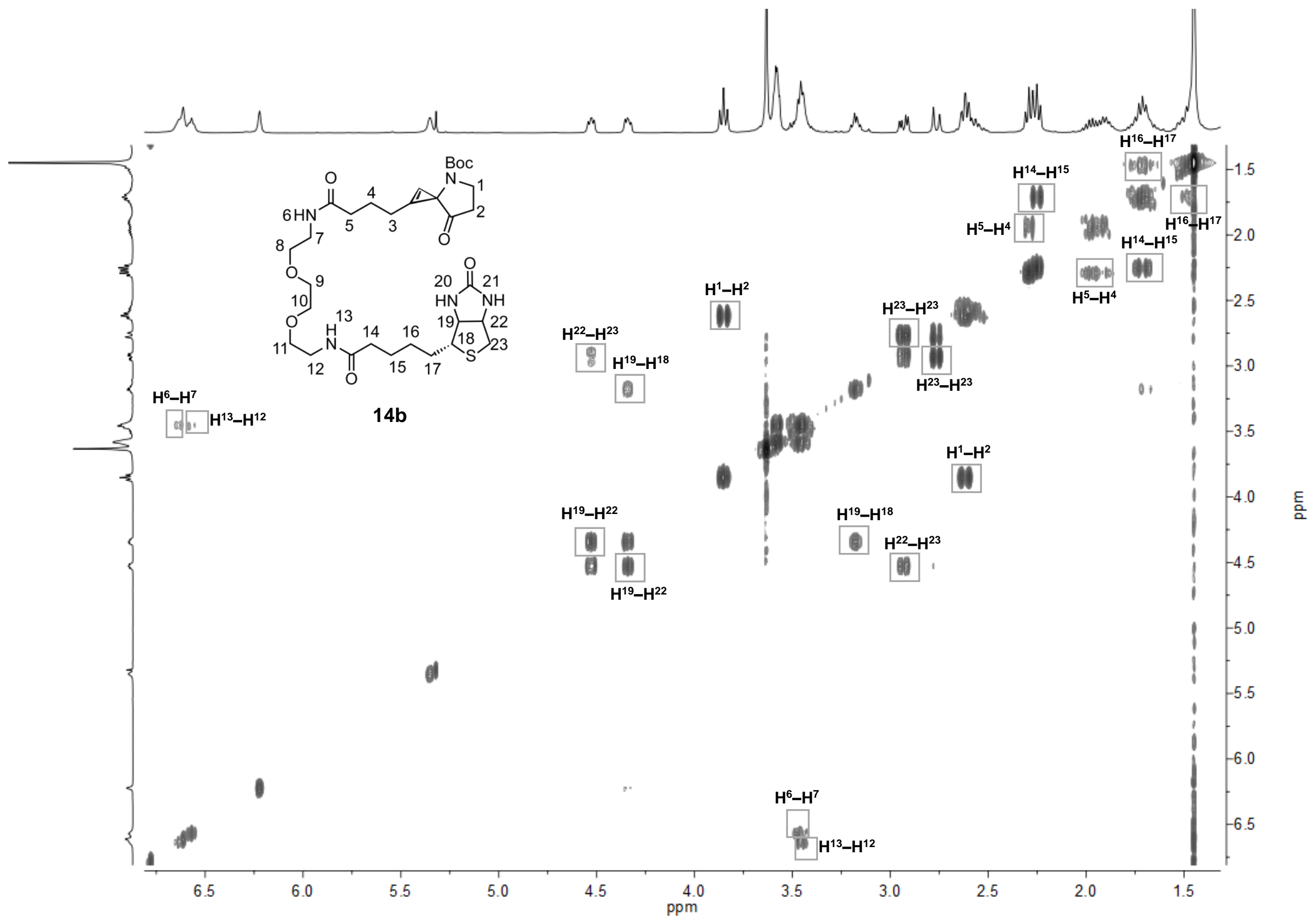

[84] 


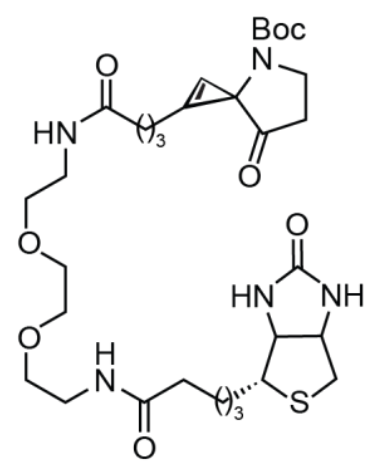

14b

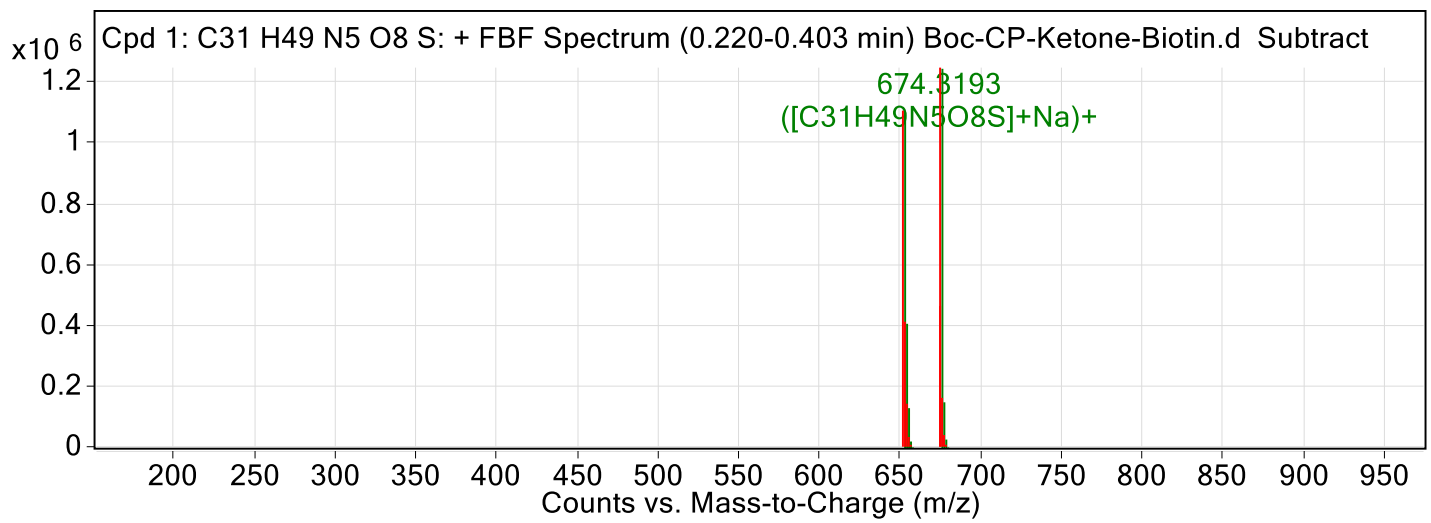

x10 6 Cpd 1: C31 H49 N5 O8 S: +ESI Scan (0.220-0.403 min, 12 Scans) Frag=150.0V Boc-CP-Ketone-...

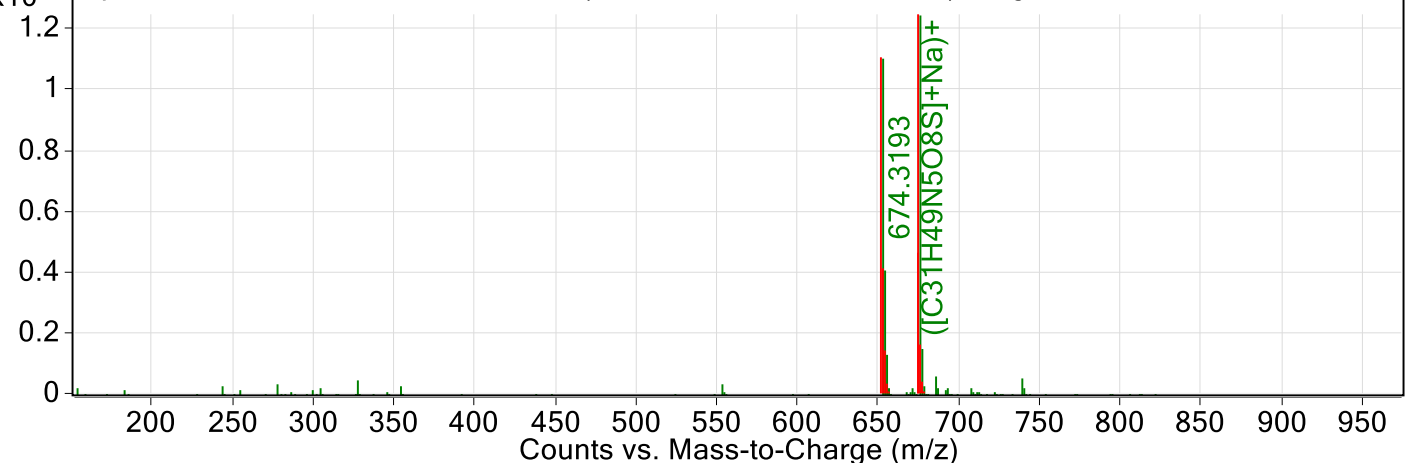


${ }^{1} \mathrm{H}$ NMR $(500 \mathrm{MHz})$

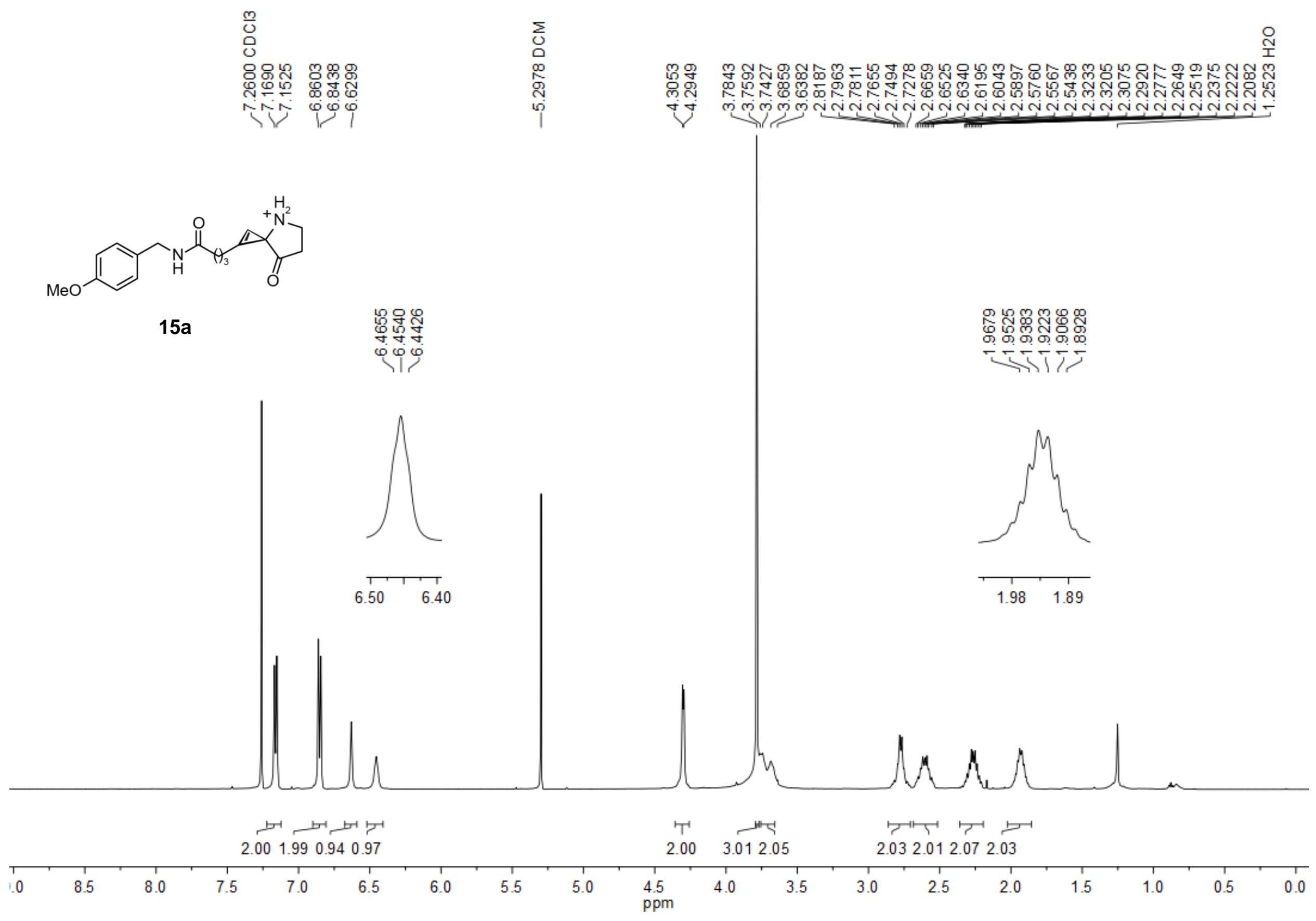

[86] 
${ }^{13} \mathrm{C}$ NMR $(126 \mathrm{MHz})$

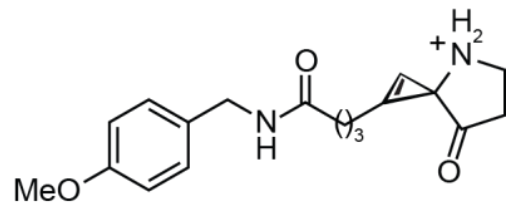

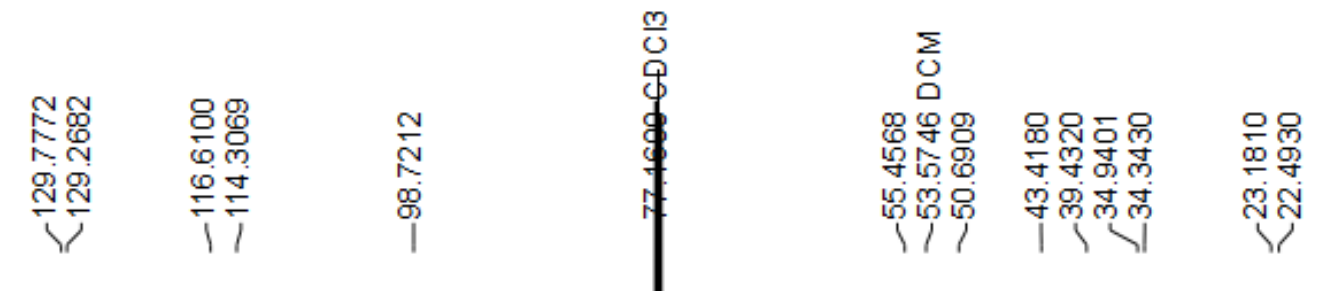

15a

$\begin{array}{lllllllllll}210 & 200 & 190 & 180 & 170 & 160 & 150 & 140 & 130 & 120 & \begin{array}{c}110 \\ \mathrm{ppm}\end{array} \\ & & & & & & & & & \end{array}$

[87] 
COSY NMR (500 MHz)

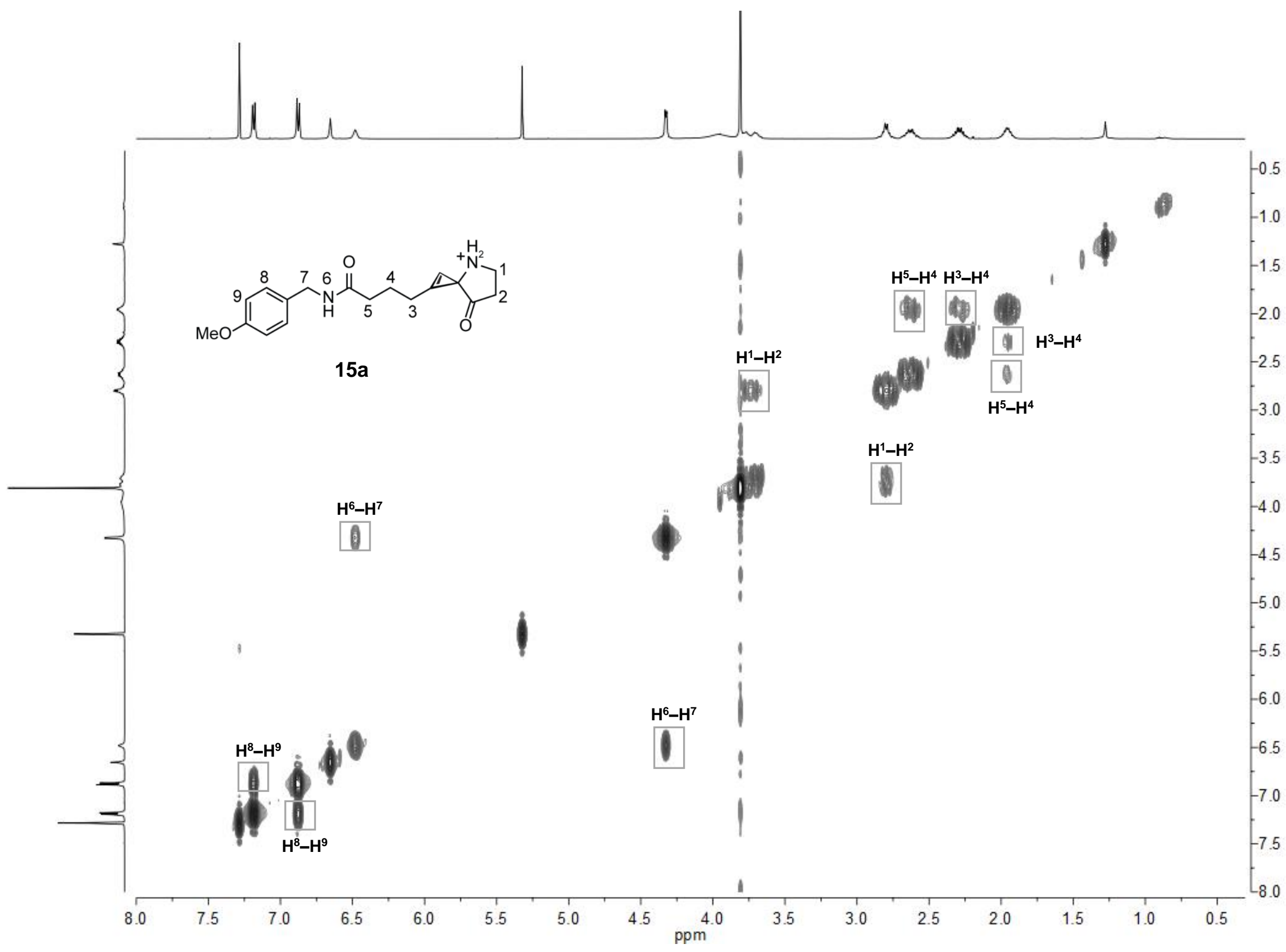




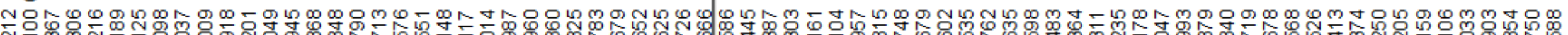
雨
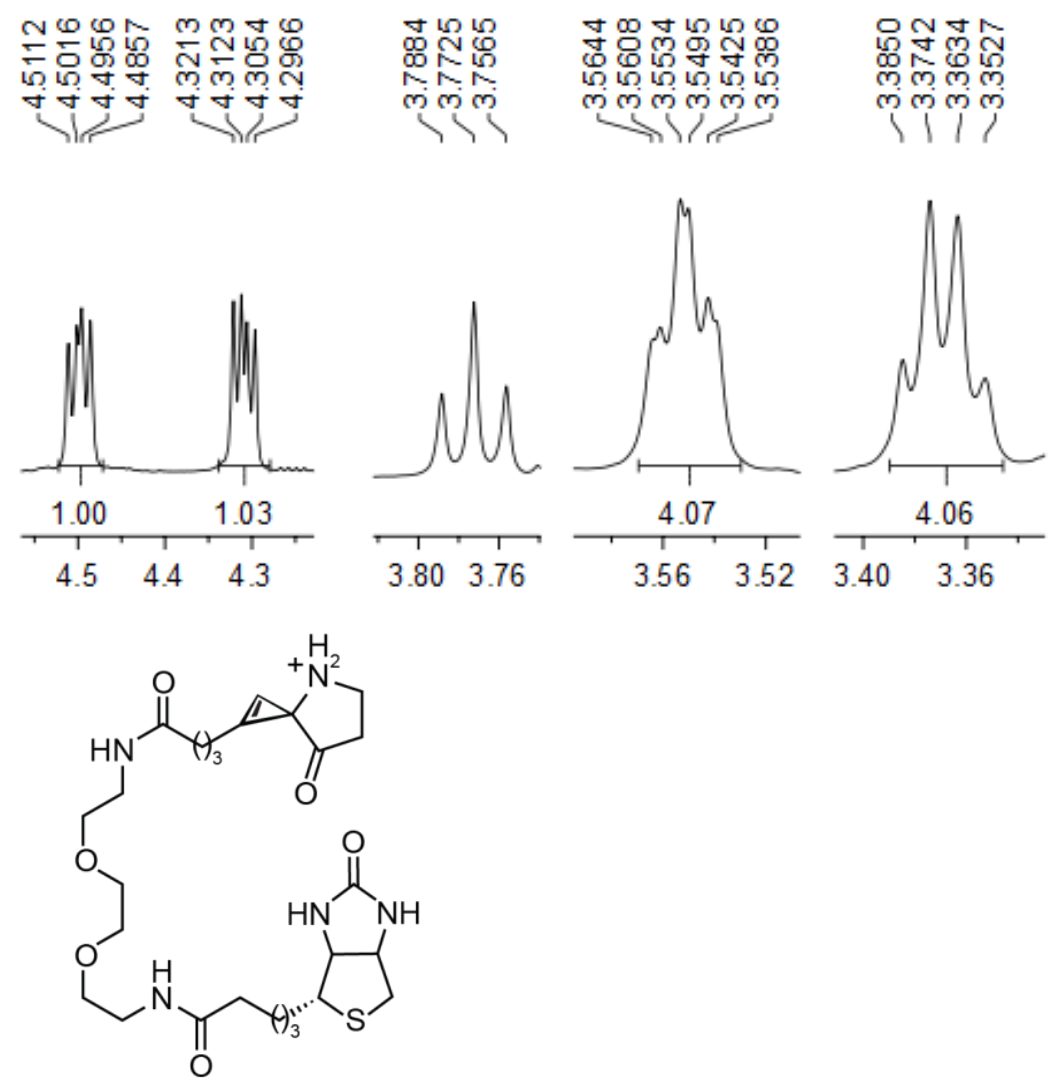

$15 b$
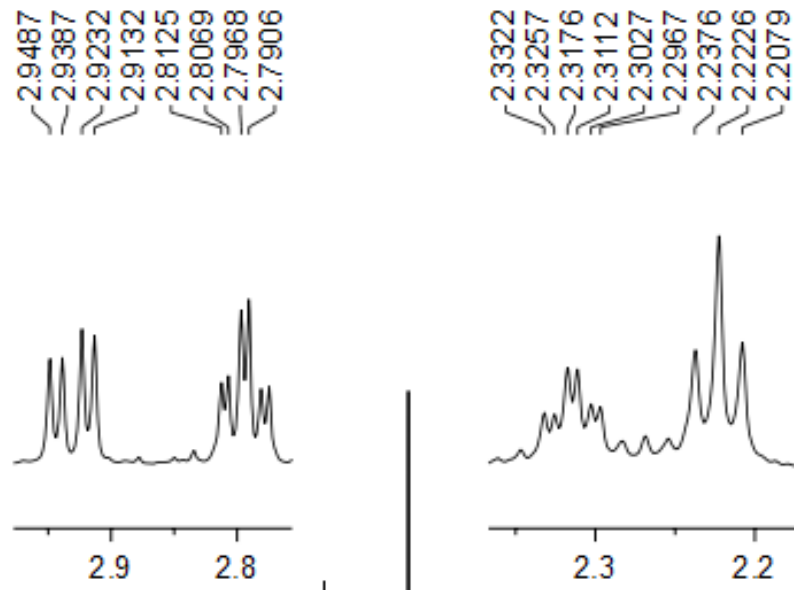

2.3
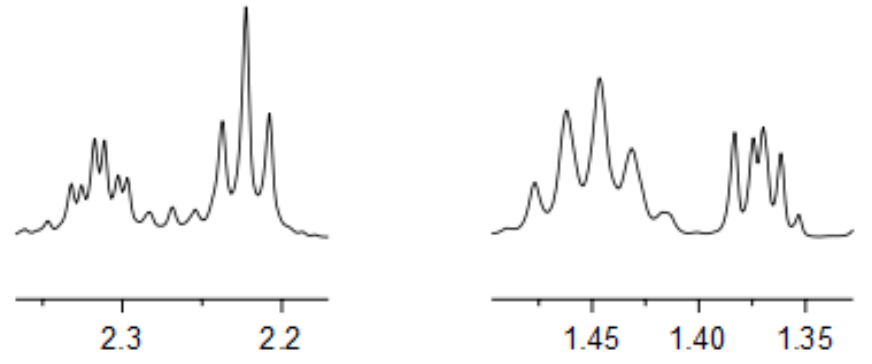
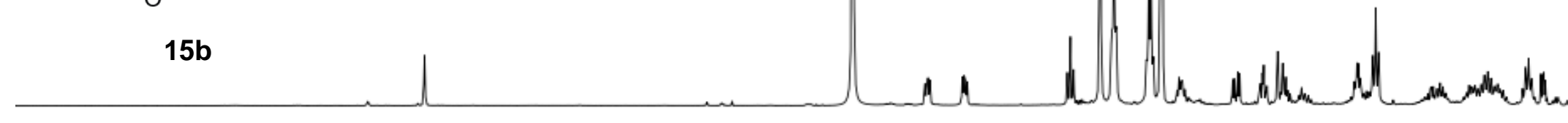

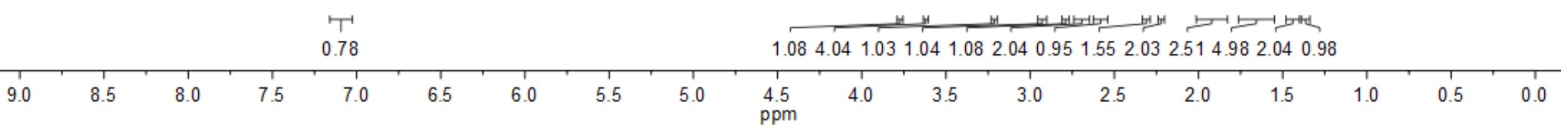


${ }^{13} \mathrm{C}$ NMR $(126 \mathrm{MHz})$

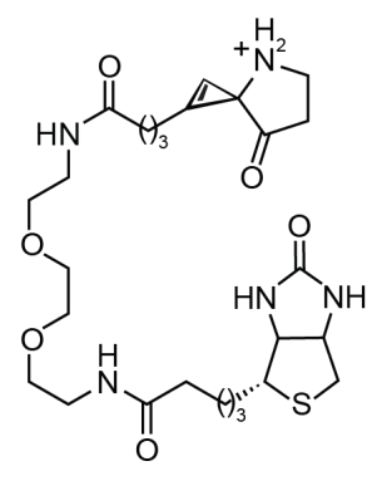

$15 b$

舫品

in

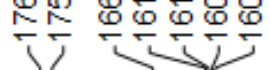

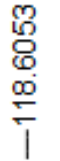

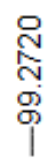

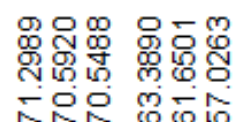

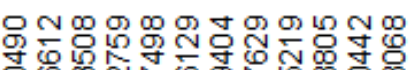

守导每

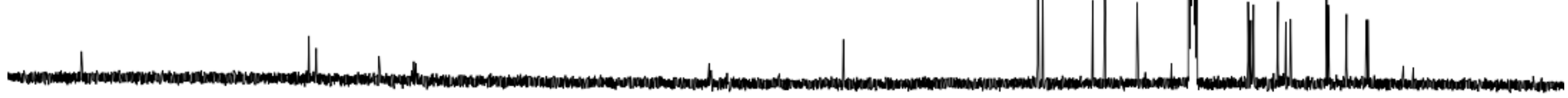

$210 \quad 200$

190

180

170

160

150

140

130

120 


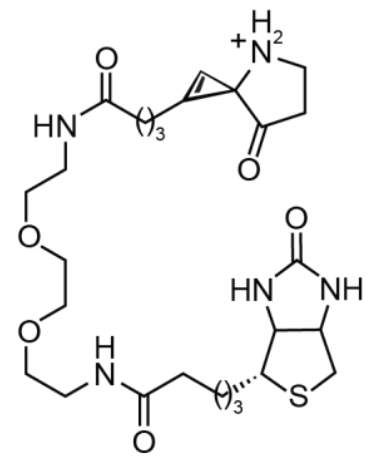

15b
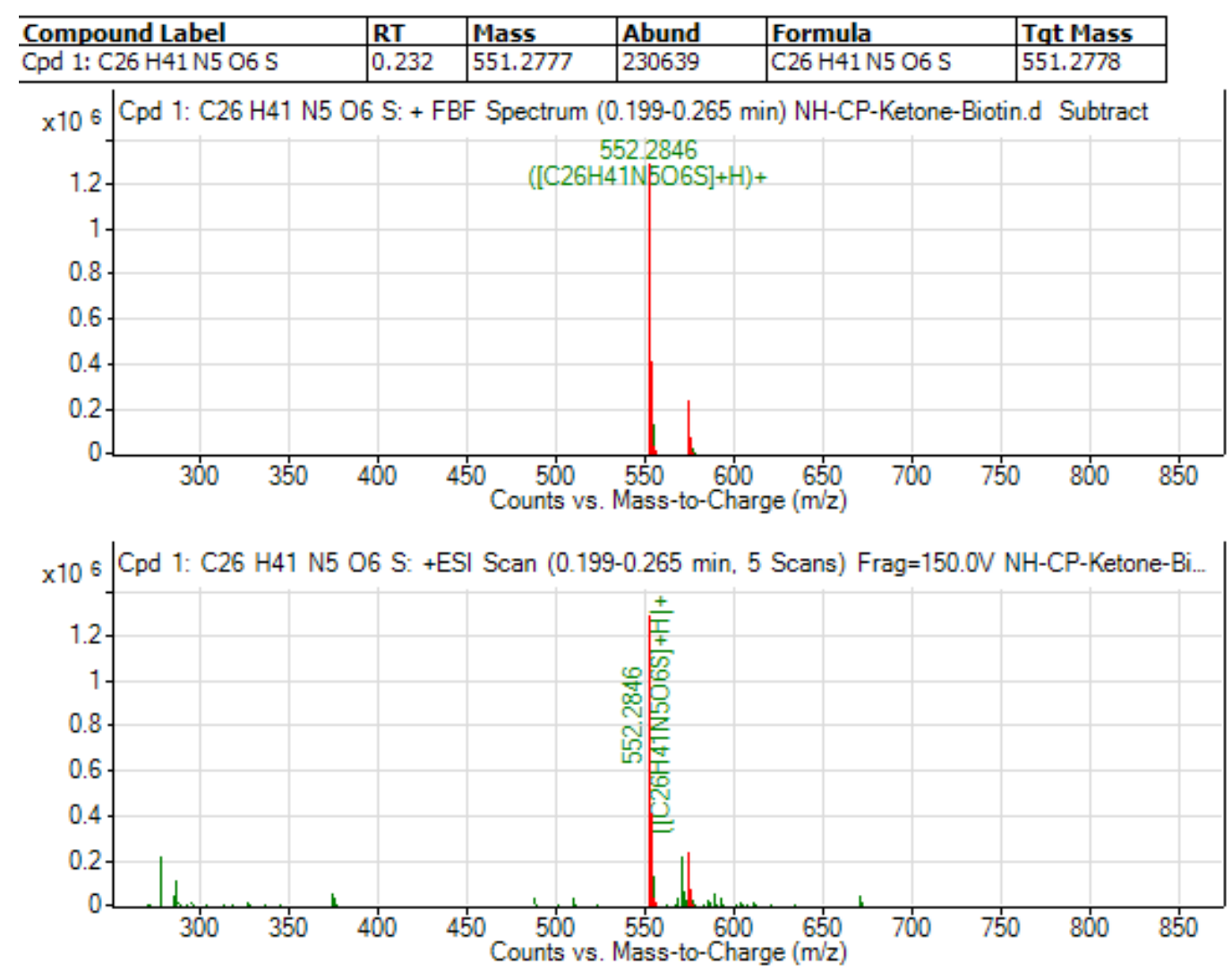

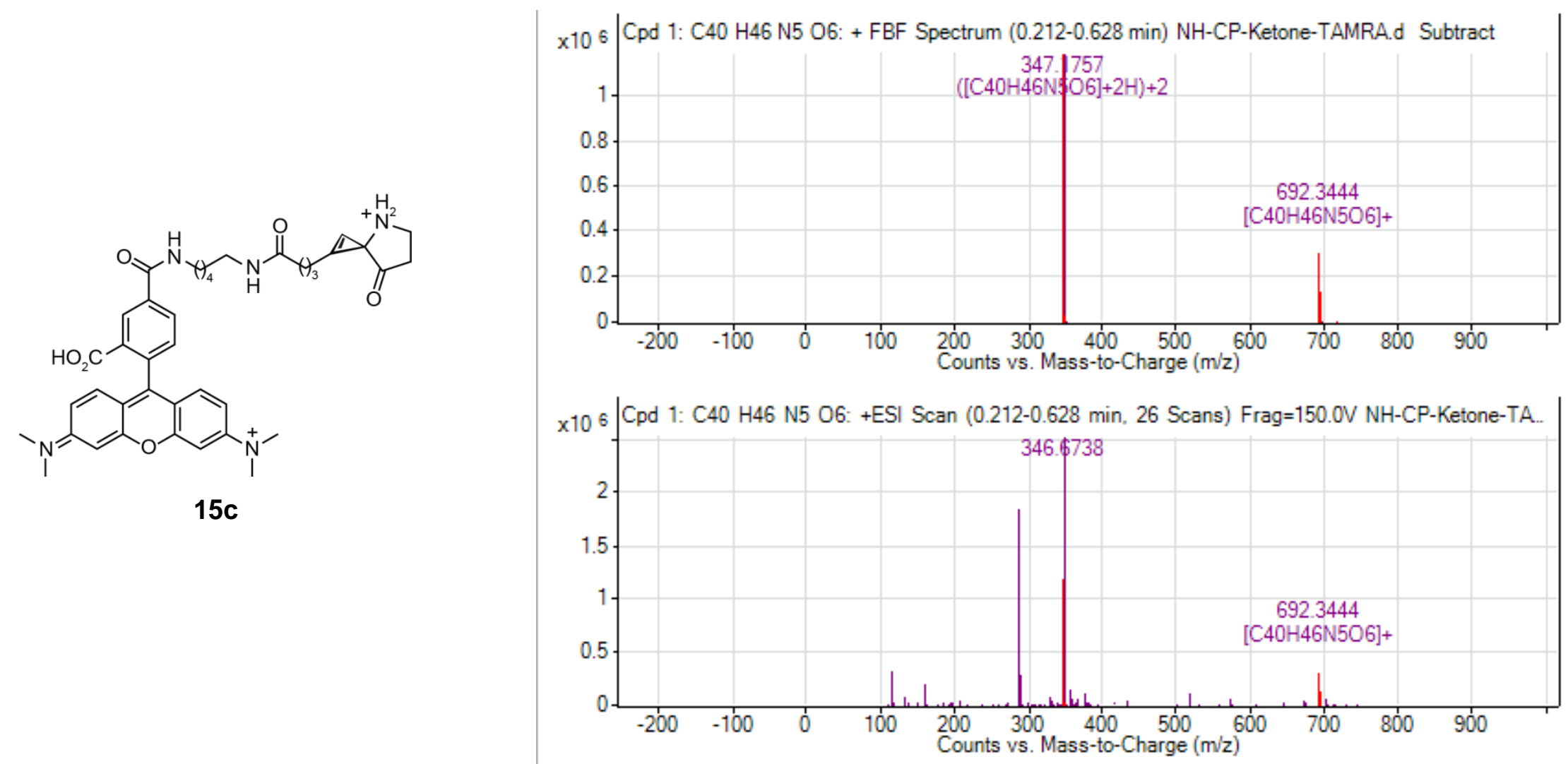
HPLC trace of $15 c$ stored in DMSO

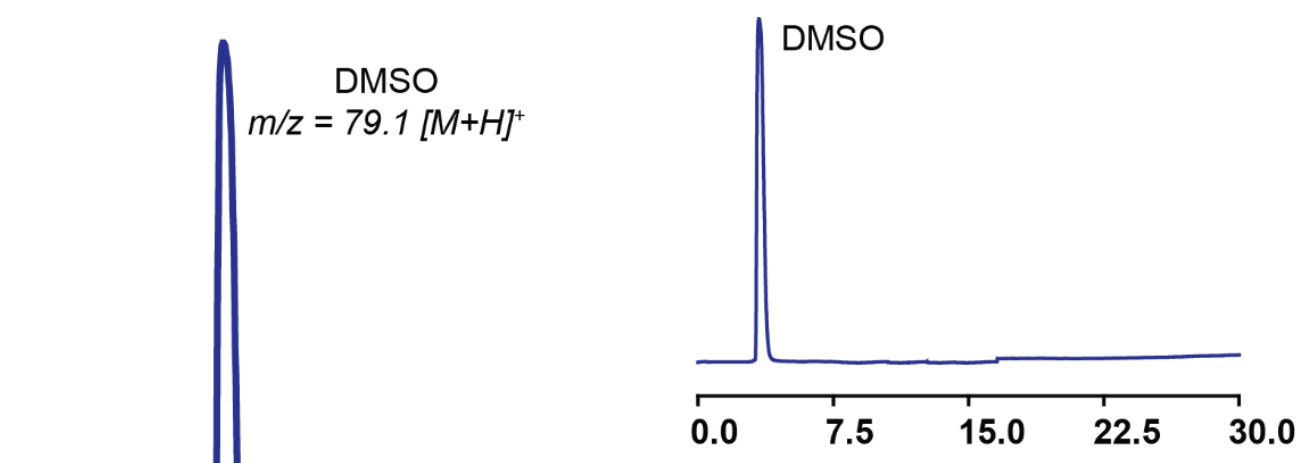

$\left.{ }_{14 \mathrm{C}} \mathrm{C}\right]^{+}, 346.7[\mathrm{M}+\mathrm{H}]^{2+}$

$\mathrm{m} / \mathrm{z}=692.3[\mathrm{M}]^{+}, 346.7[\mathrm{M}+\mathrm{H}]^{2+}$
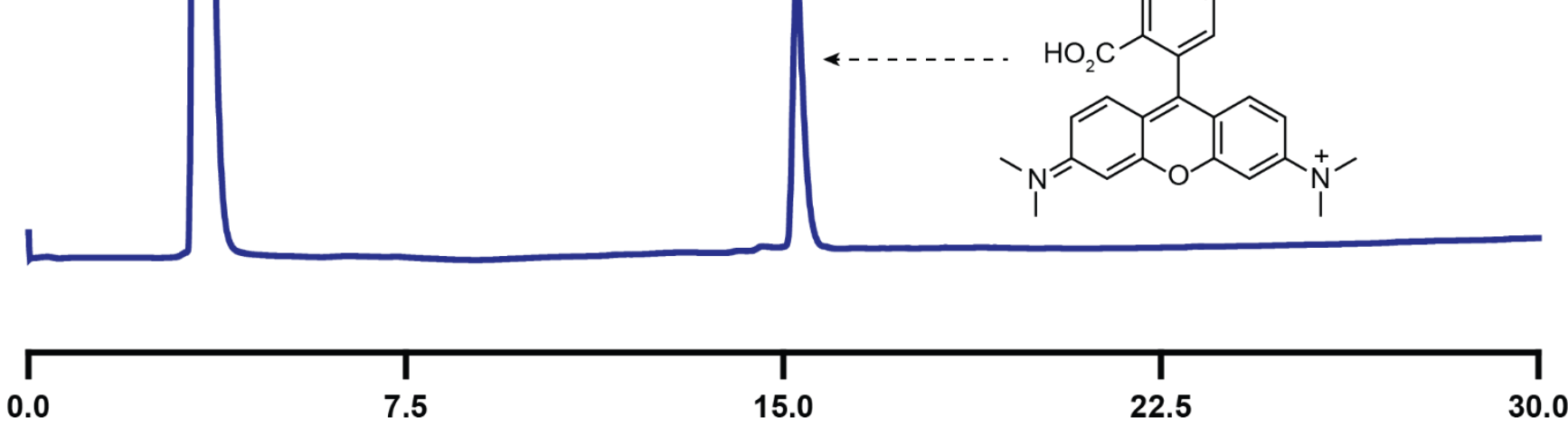

Retention time ( $\mathrm{min})$ 
视

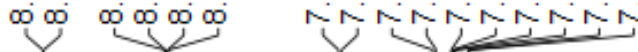

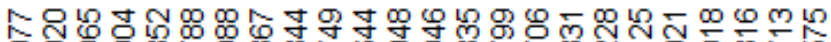
\% ํำ

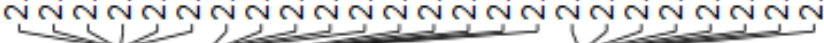
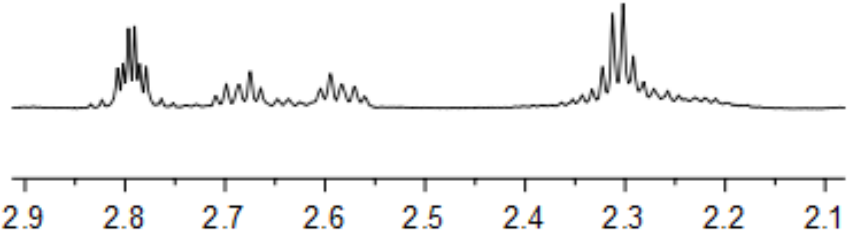

\section{${ }^{1} \mathrm{H}$ NMR $(700 \mathrm{MHz})$}

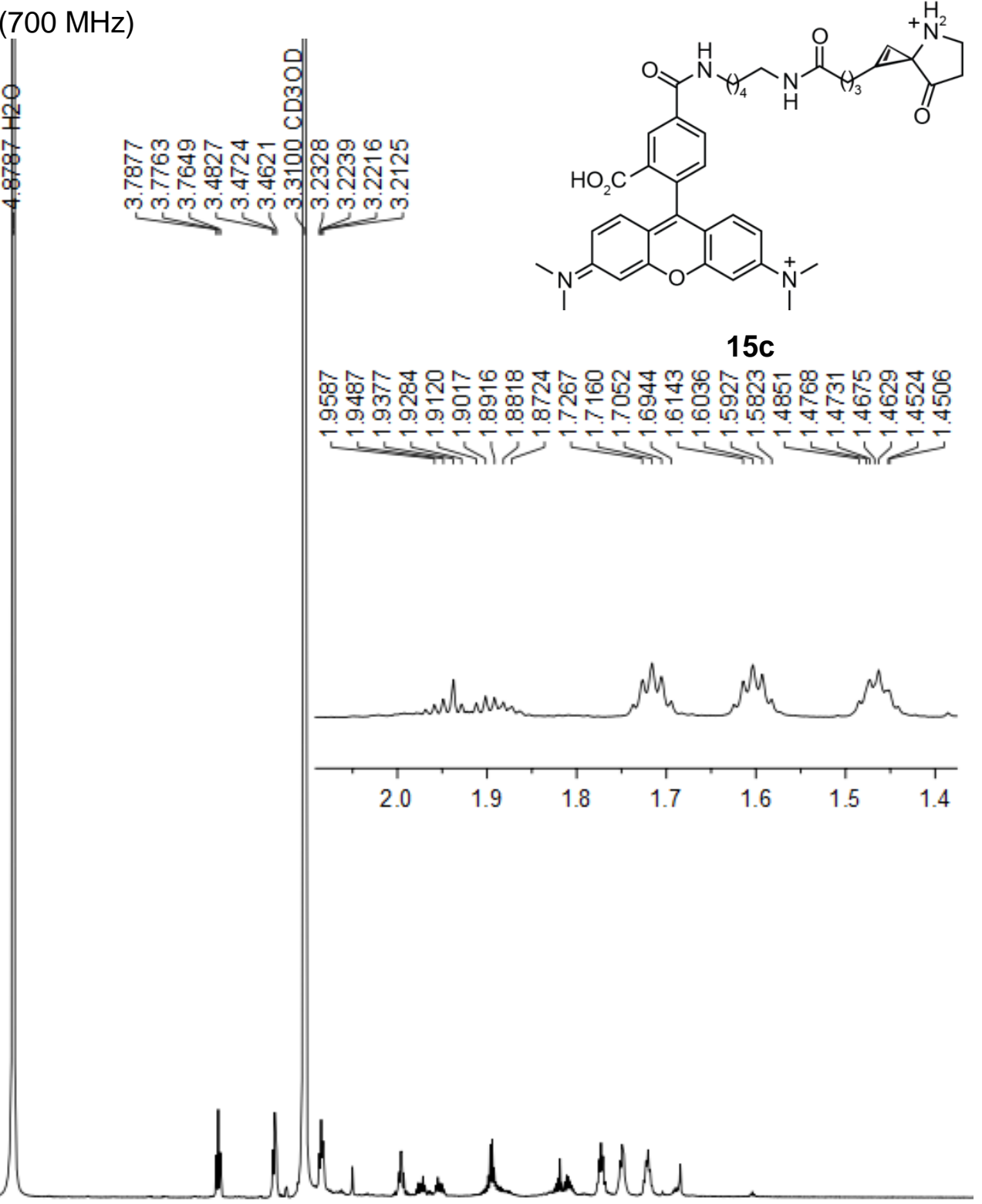

T' T'

1.071 .5411 .972 .101 .070 .941 .093 .502 .982 .002 .072 .05

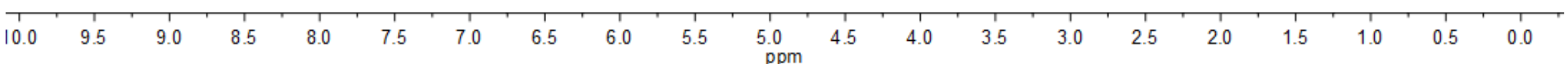


${ }^{13} \mathrm{C}$ NMR $(126 \mathrm{MHz})$

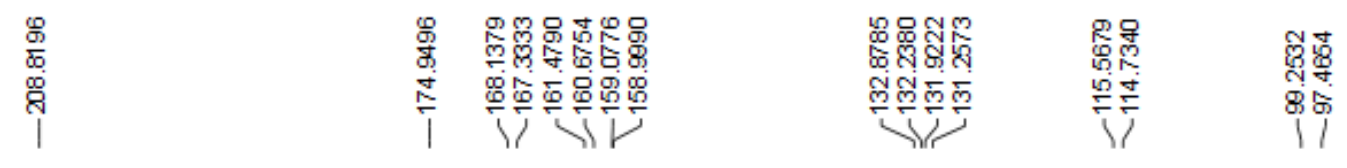

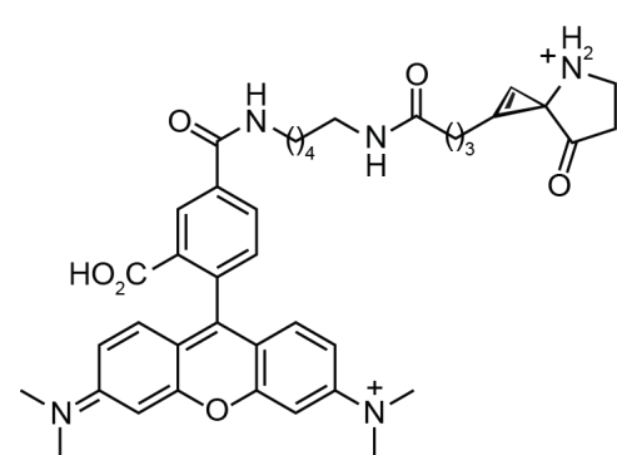

15c

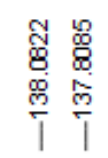

Nownow"

137.7

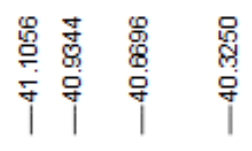

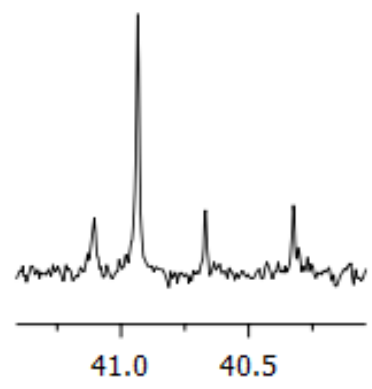

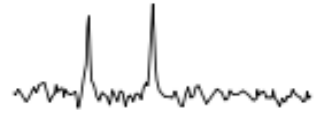

$24.2 \quad 24.0 \quad 23.823 .6$

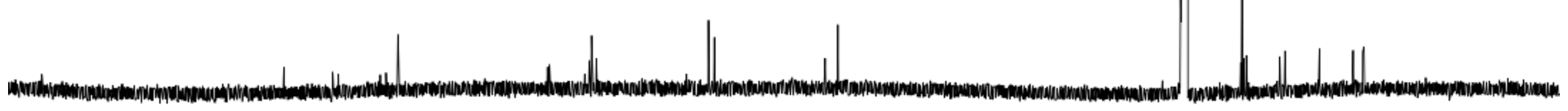




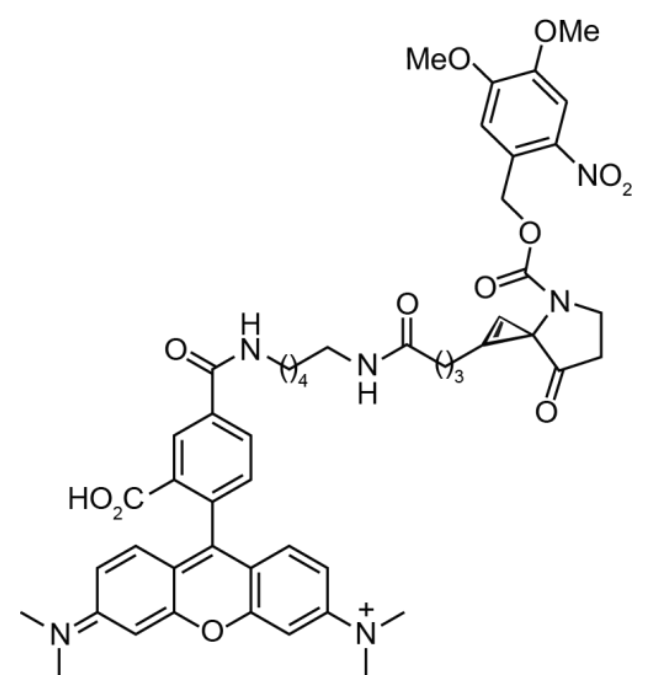

16c
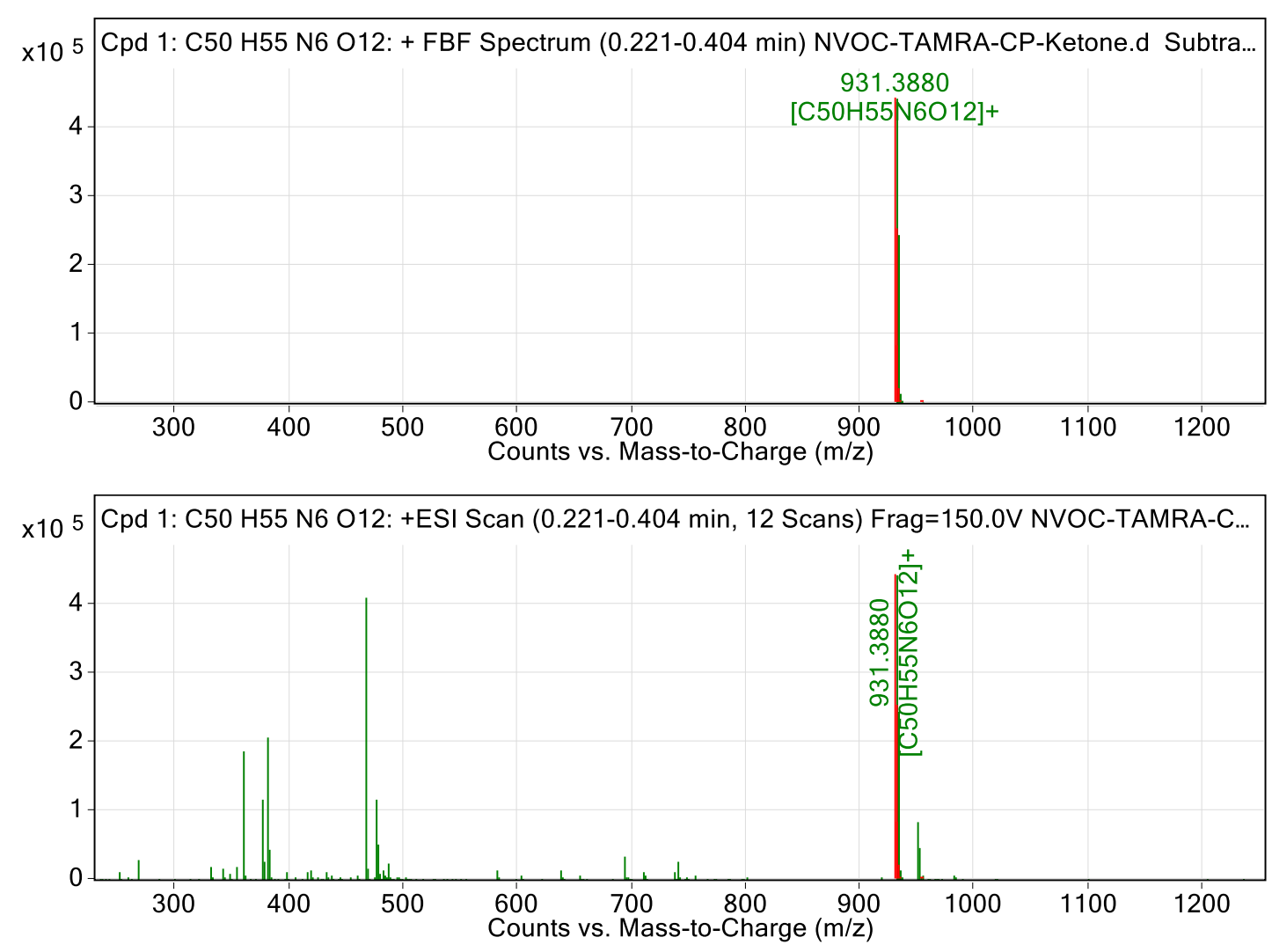
HPLC trace of $16 \mathrm{c}$ stored in DMSO

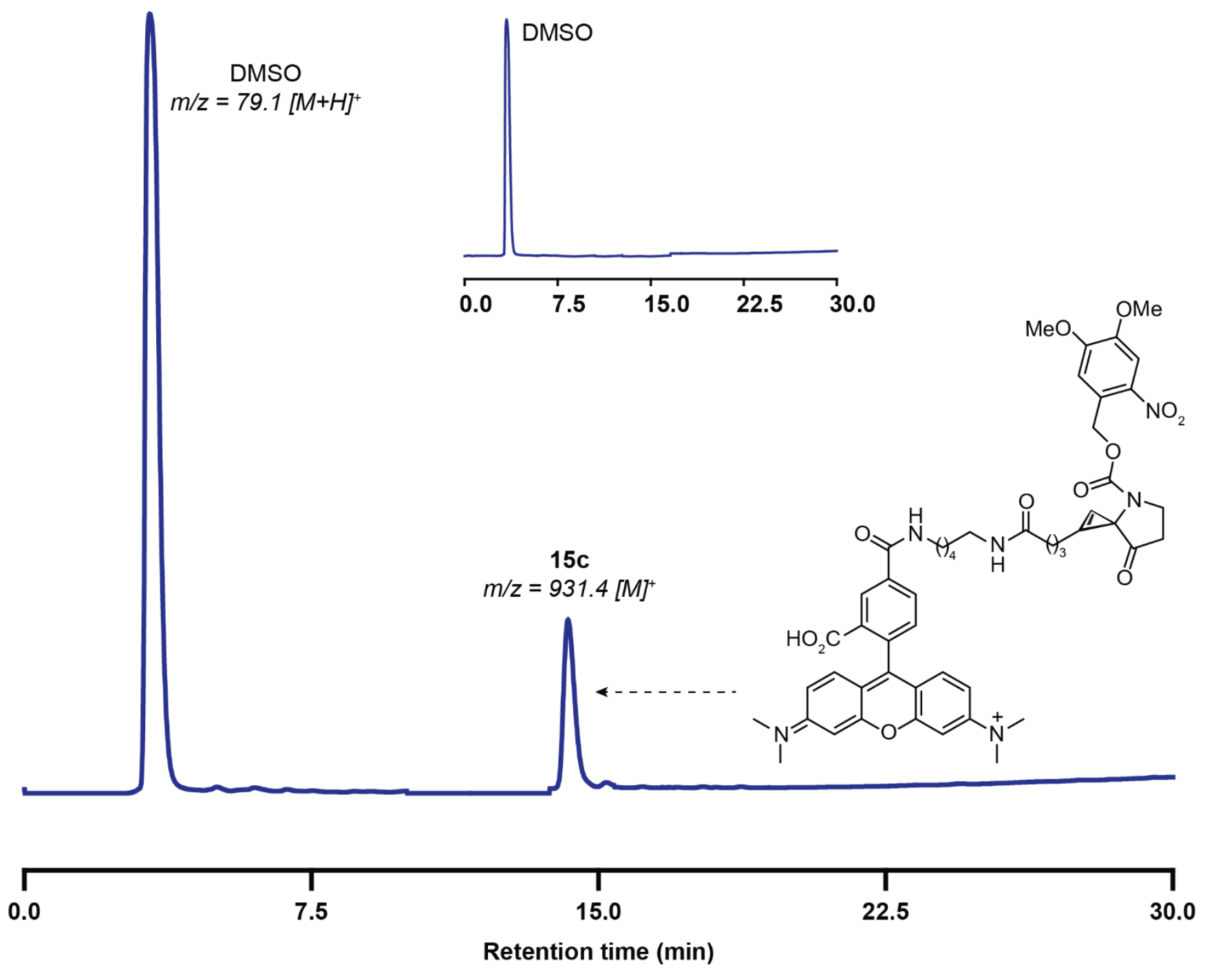


${ }^{1} \mathrm{H}$ NMR $(700 \mathrm{MHz})$

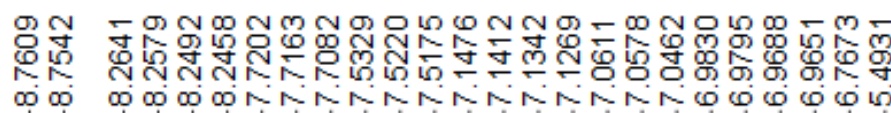

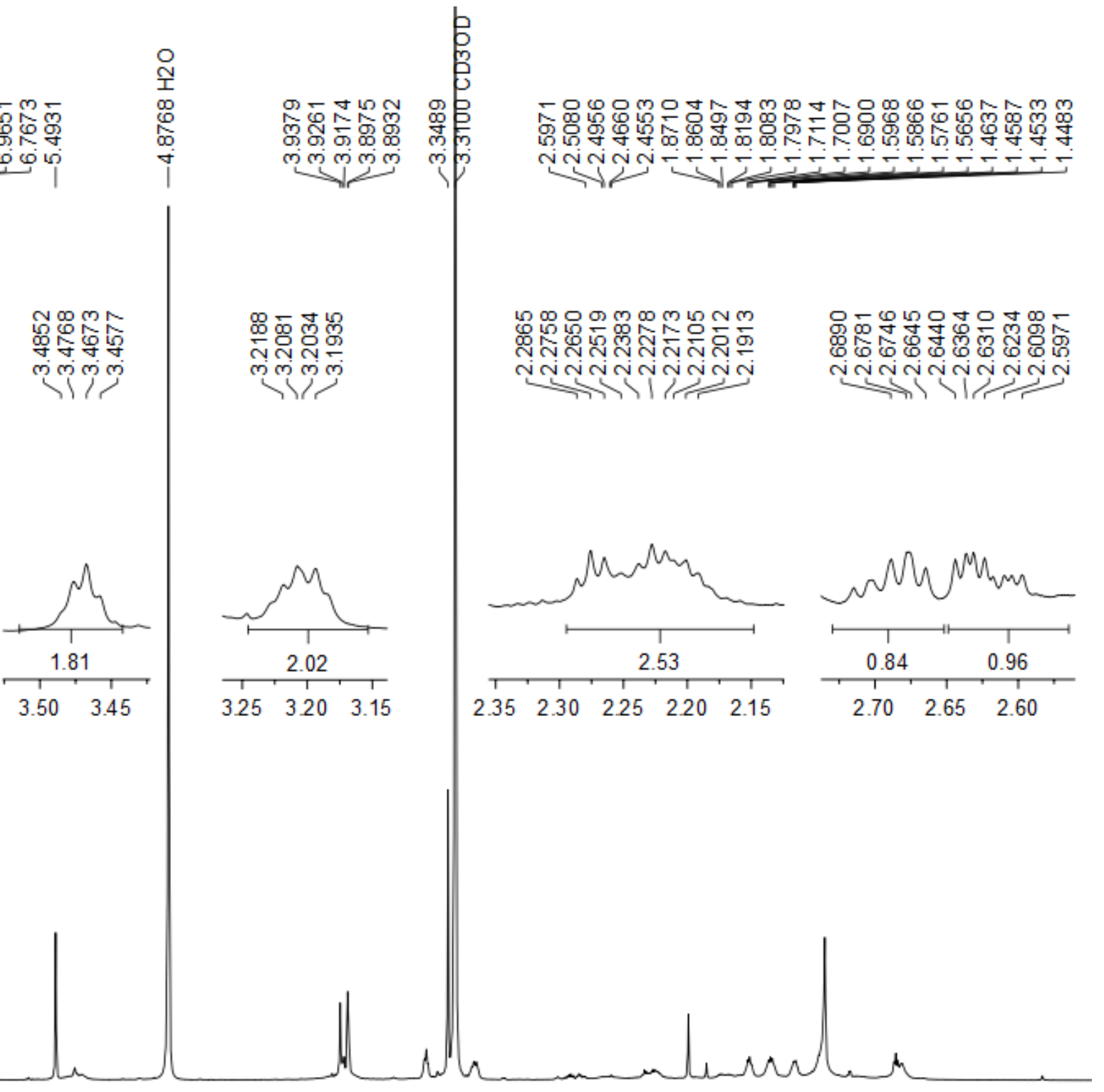

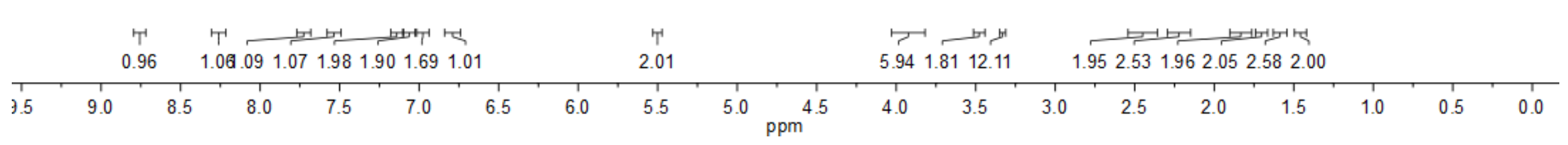


${ }^{13} \mathrm{C}$ NMR $(176 \mathrm{MHz})$

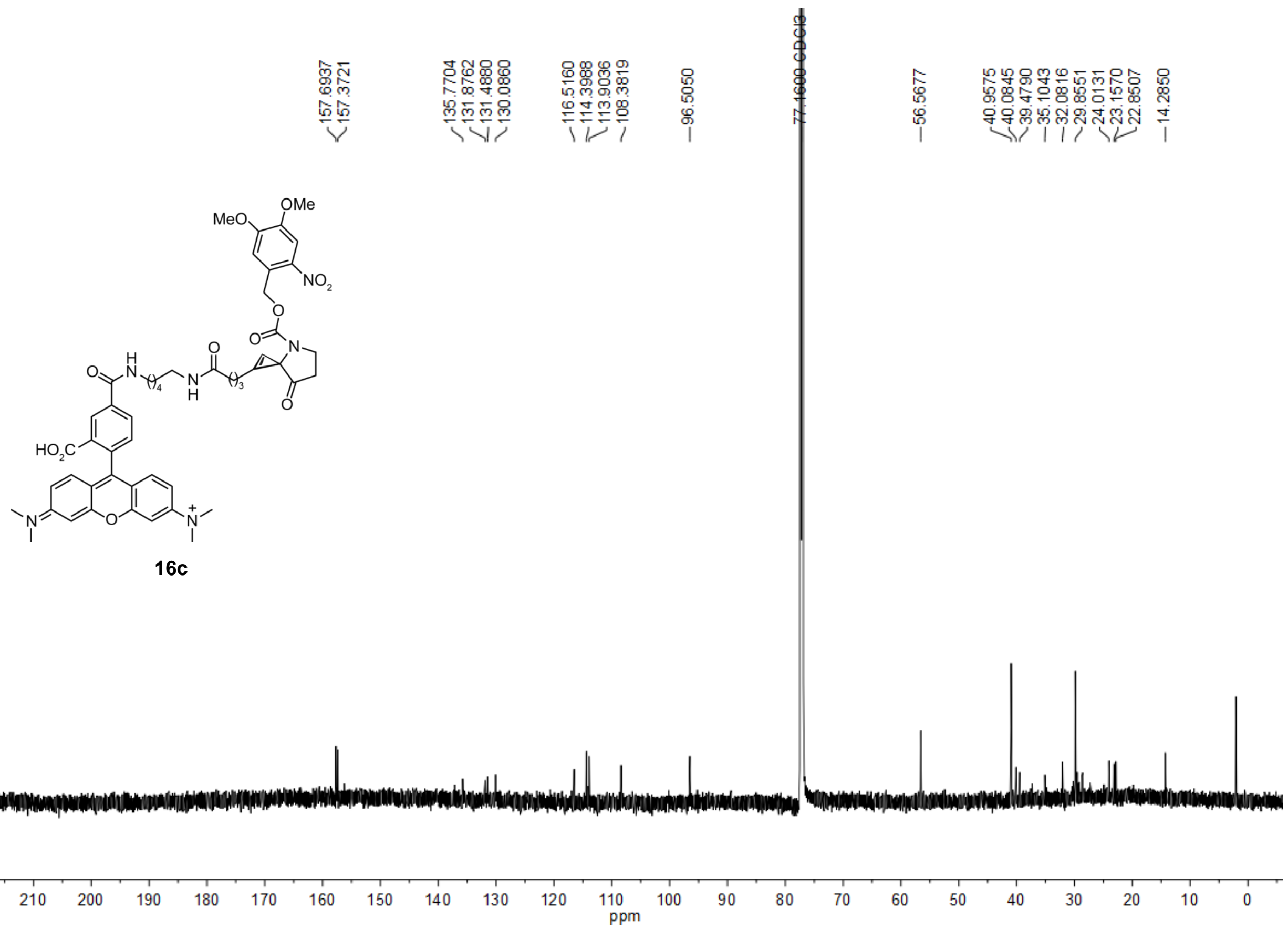

[99] 
Figure S1: UV-Vis absorbance spectrum of 10a

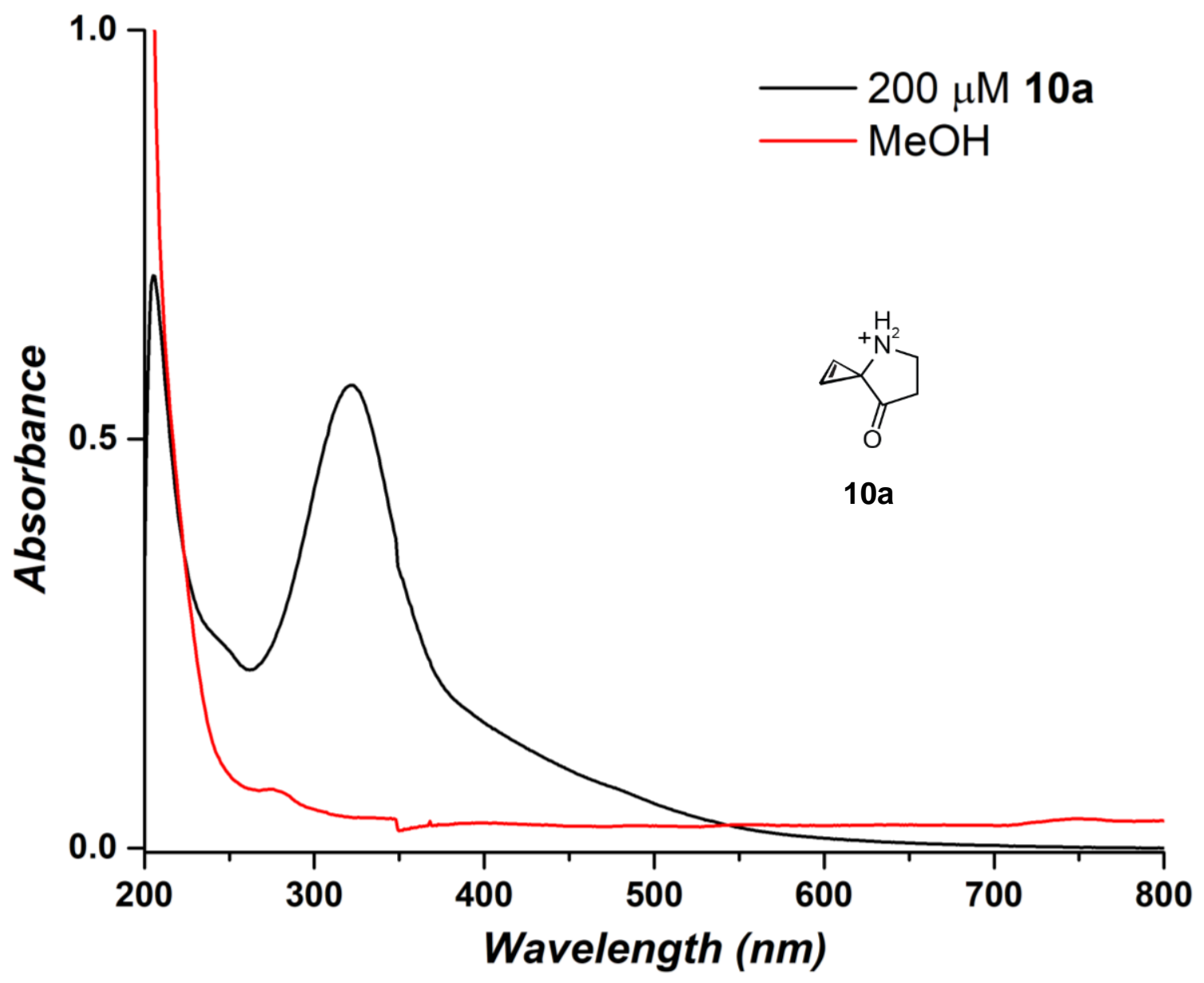


Figure S2: Absorbance (at $520 \mathrm{~nm}$ ) of $10 \mathrm{a}$ in 1:1 PBS/MeOH

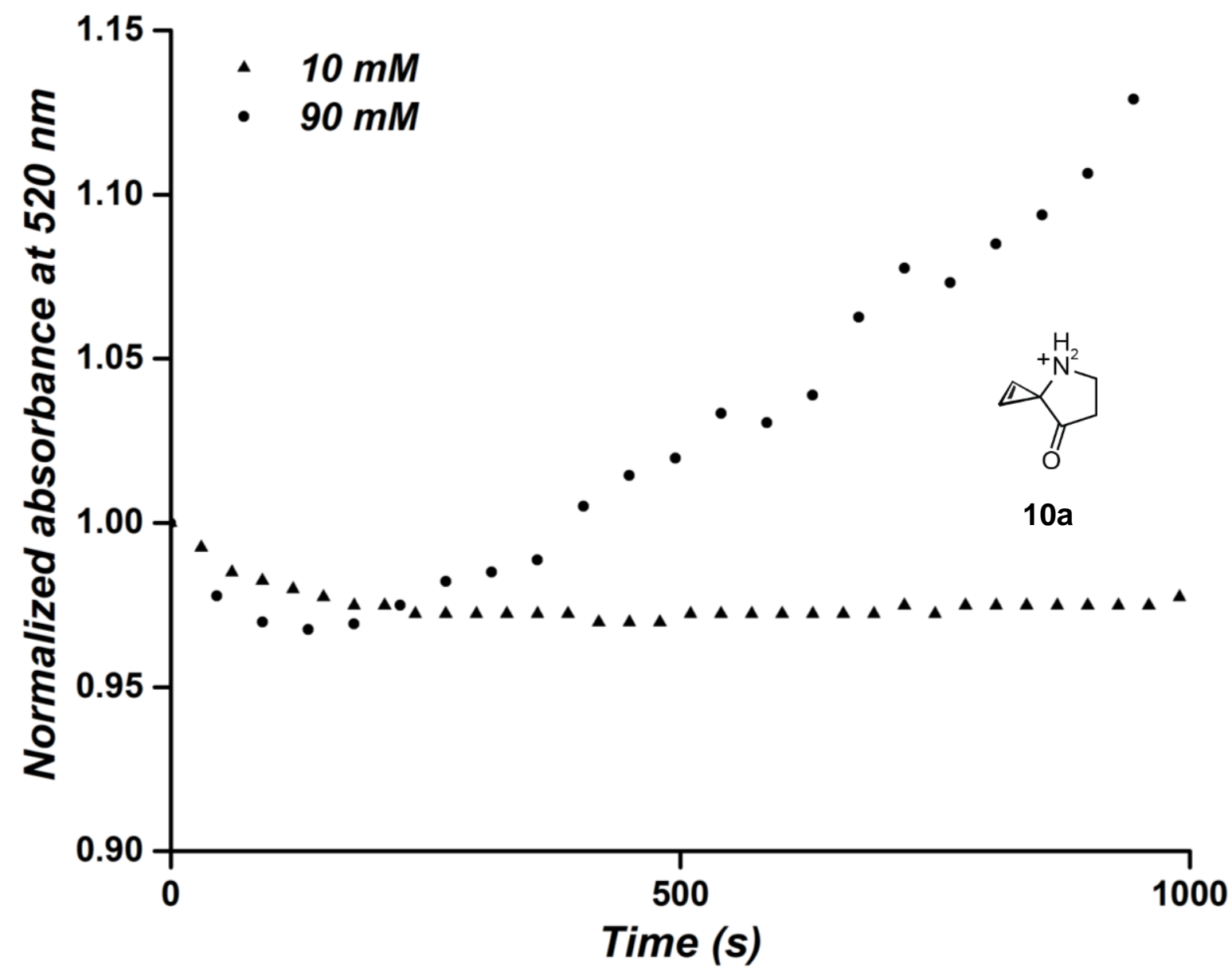


${ }^{1} \mathrm{H}$ NMR of 10a in MeOD $(700 \mathrm{MHz})$

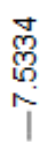

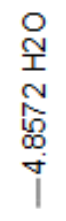

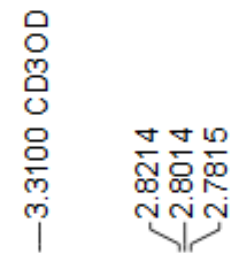

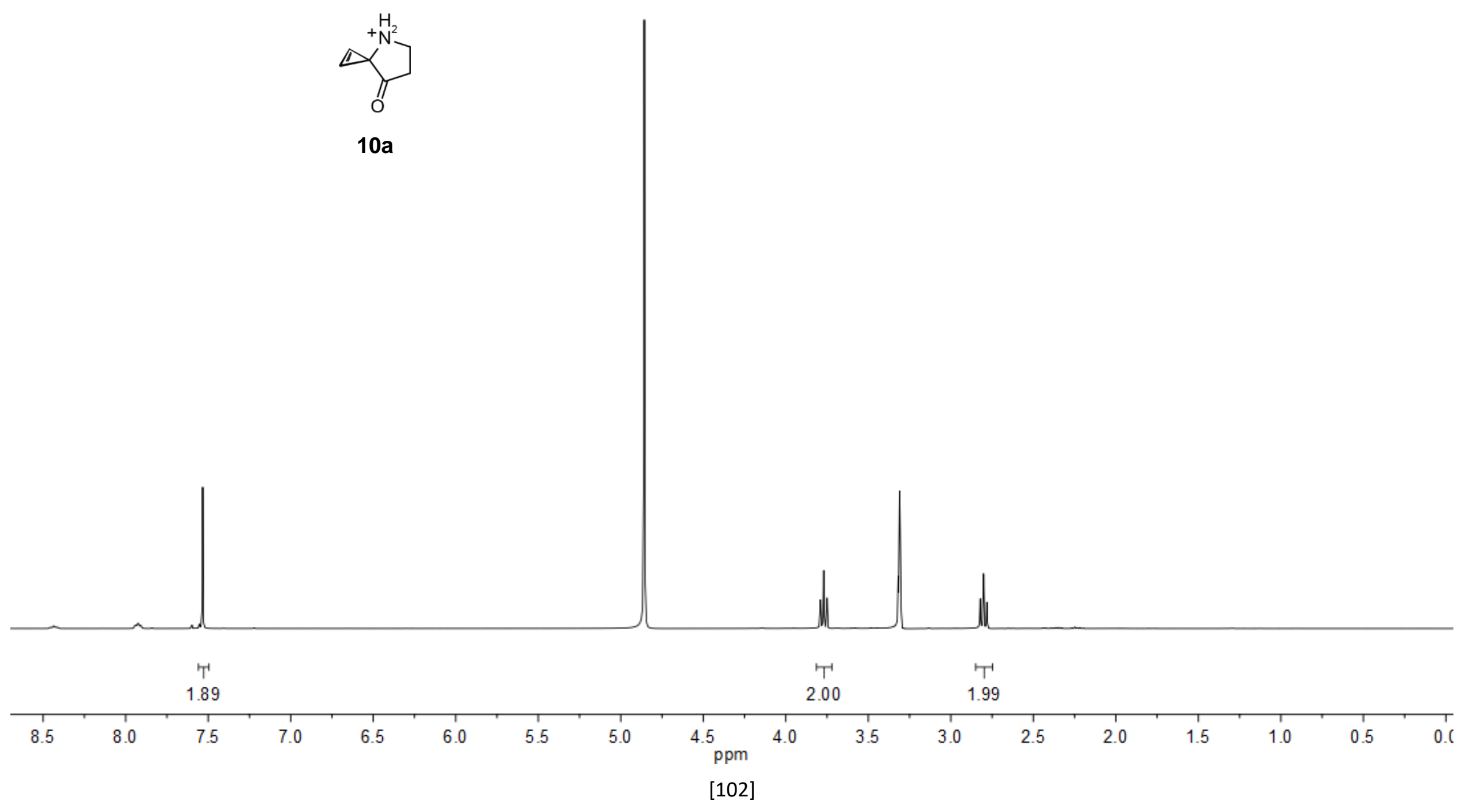


Figure S3: ${ }^{1} \mathrm{H}$ NMR of $90 \mathrm{mM}$ 10a in 1:1 $\mathrm{CD}_{3} \mathrm{OD} / \mathrm{d}-\mathrm{PBS}(400 \mathrm{MHz})$

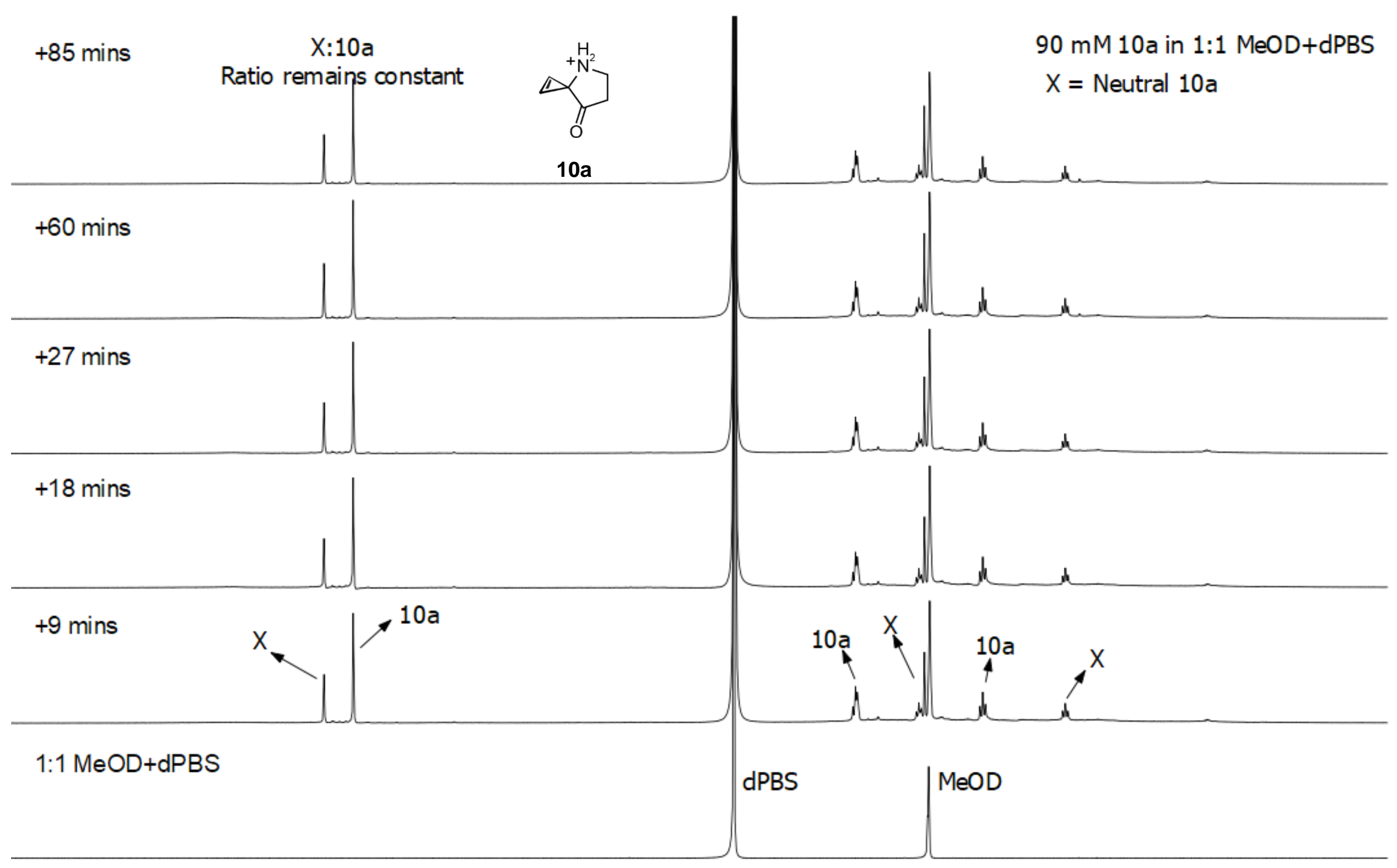

\begin{tabular}{|c|c|c|c|c|c|c|c|c|c|c|c|c|c|c|c|c|c|c|c|c|}
\hline 0 & 9.5 & 9.0 & 8.5 & 8.0 & 7.5 & 7.0 & 6.5 & 6.0 & 5.5 & $\begin{array}{l}5.0 \\
\mathrm{ppm} \\
{[103]}\end{array}$ & 4.5 & 4.0 & 3.5 & 3.0 & 2.5 & 2.0 & 1.5 & 1.0 & 0.5 & 0.0 \\
\hline
\end{tabular}


Figure S4: COSY NMR of $90 \mathrm{mM}$ 10a in 1:1 $\mathrm{CD}_{3} \mathrm{OD} / \mathrm{d}-\mathrm{PBS}(400 \mathrm{MHz})$

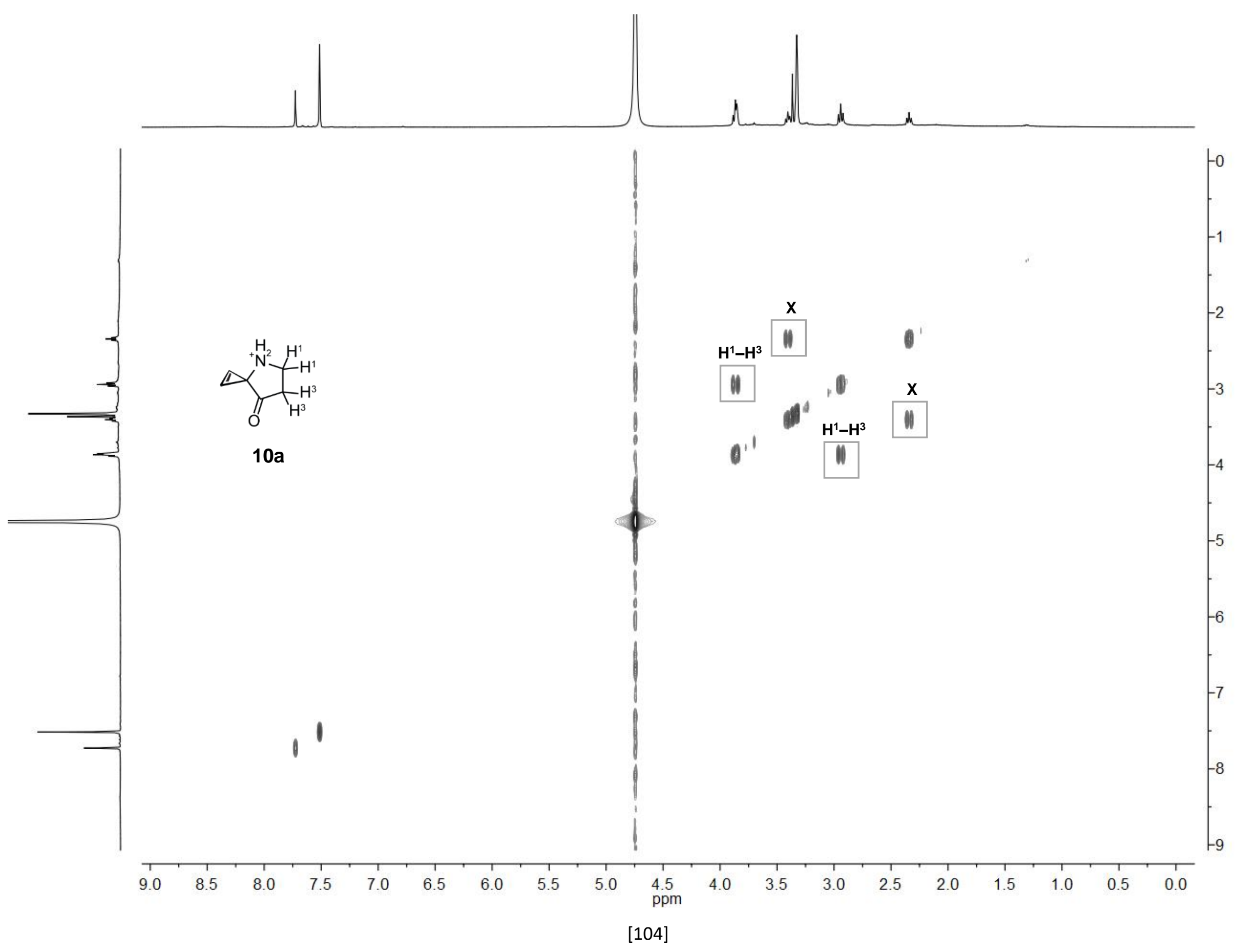




\section{Figure S5: ${ }^{1} \mathrm{H}$ NMR of $90 \mathrm{mM}$ 10a in at two different pH (400 MHz)}
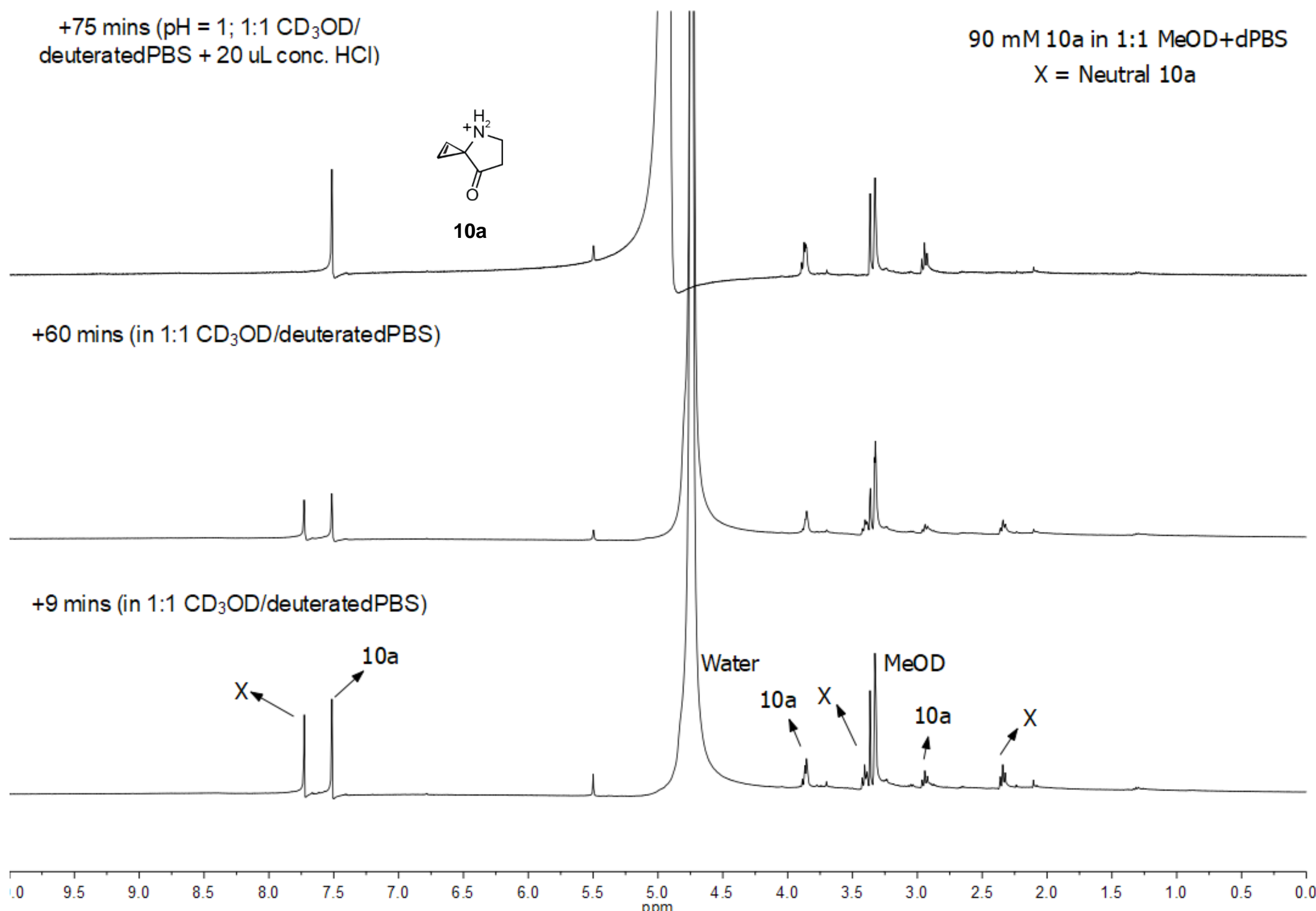

9.0




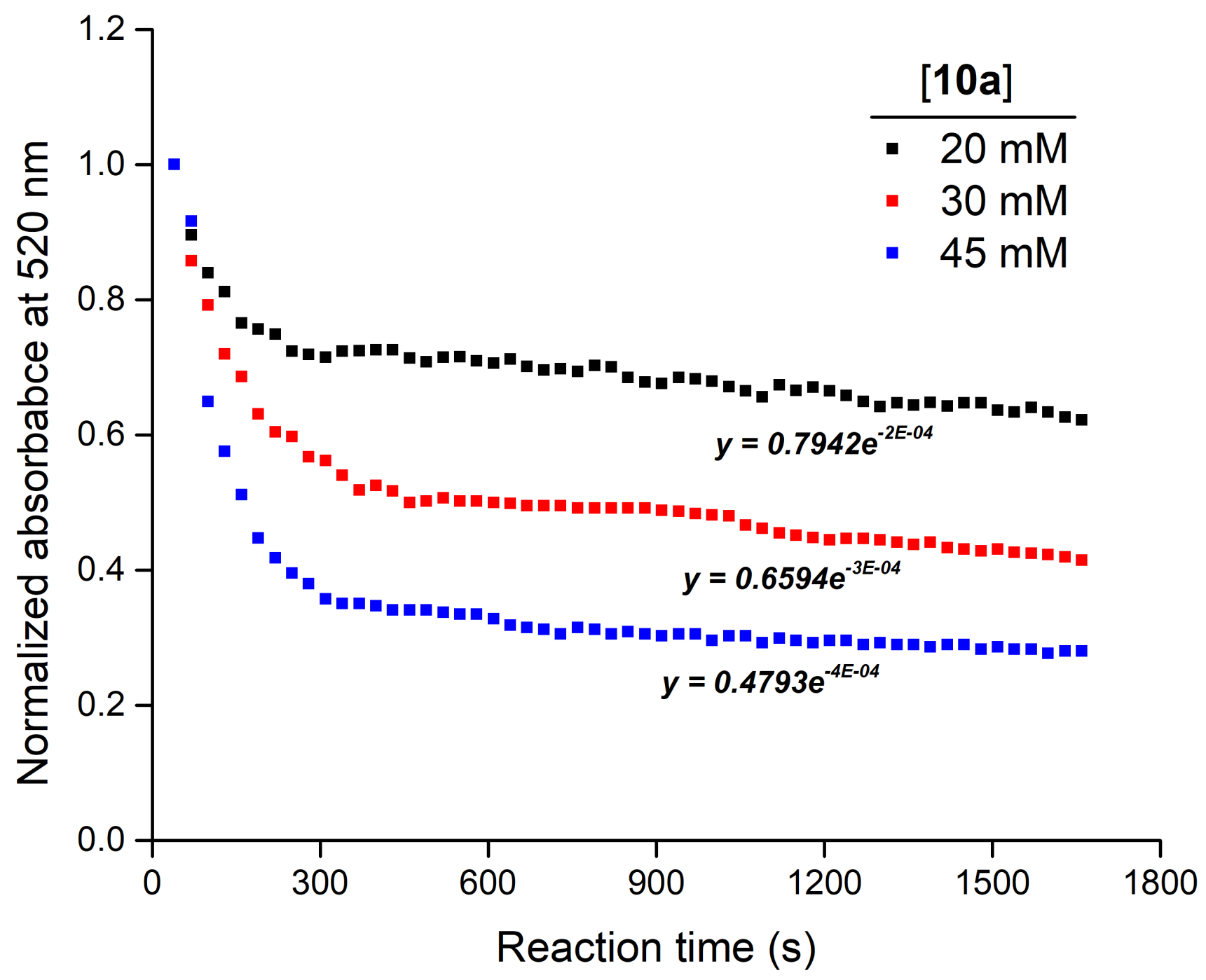

Figure S6: Kinetic evaluation of ligation between cyclopropene 10a and 3,6-Di-2-pyrdiyl-1,2,4,5-tetrazine based on general method mentioned for kinetic evaluation by mesauring abosrbacne at $520 \mathrm{~nm}$. Calculation of pseudo firstorder rate calculation. 


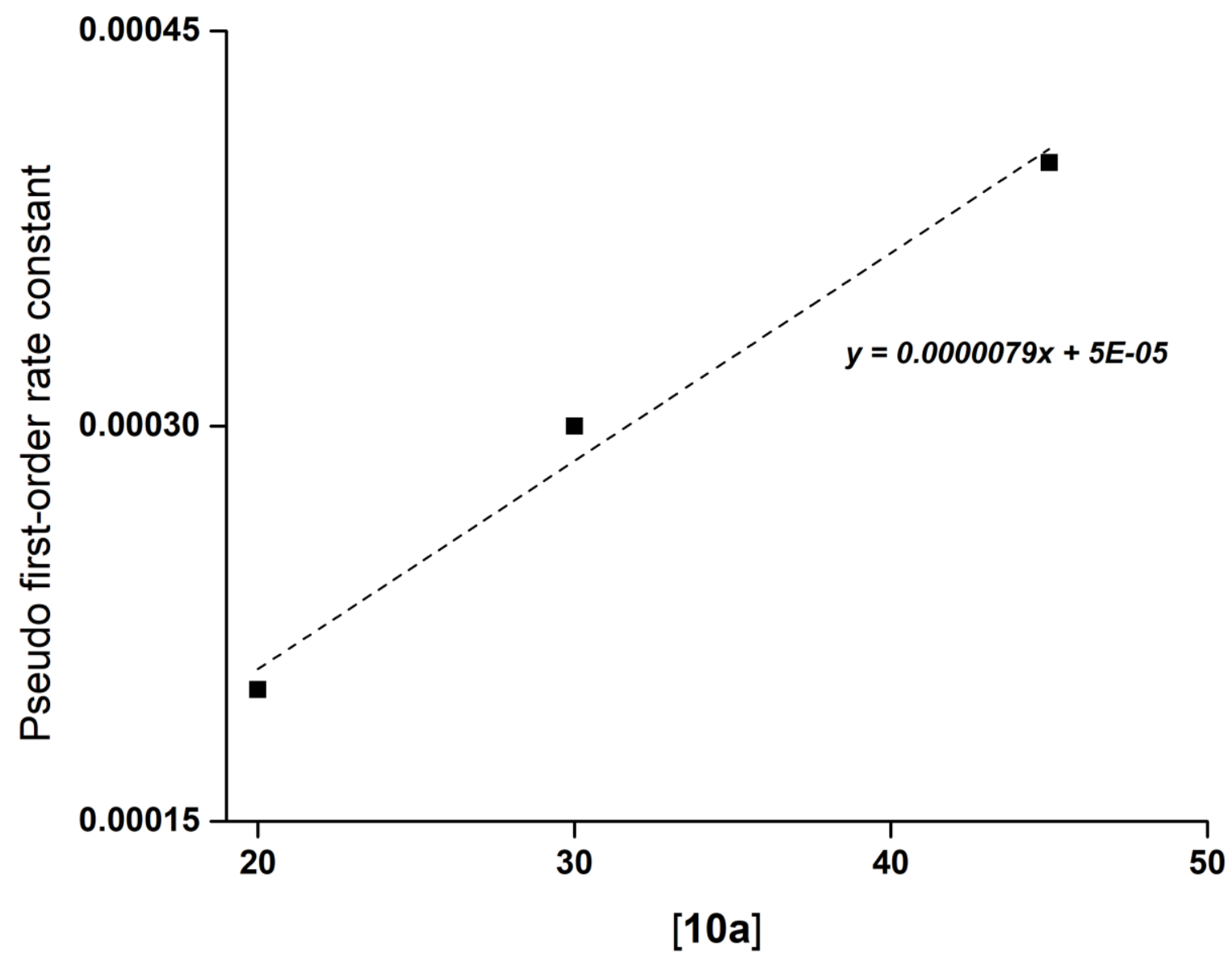

Figure S7: Kinetic evaluation of ligation between cyclopropene 10a and 3,6-Di-2-pyrdiyl-1,2,4,5-tetrazine based on general method mentioned for kinetic evaluation by mesauring abosrbacne at $520 \mathrm{~nm}$. Calculation of second order rate constant. 


\section{Scheme S7: Computational calculations}

Method

All the geometries were optimized using B3LYP hybrid functional based on density functional theory. All calculations were carried out using $6-311 G+(2 d, p)$ basis set. The stability of these $3-N$ spirocyclopropene scaffolds were predicted based on the ring separation energies (RSEs) described by Radom and co-workers. ${ }^{7}$ The ring separation reactions and the respective change in Gibbs free energies are described below. All calculations were performed on Gaussian 16 using WebMO enterprise edition. ${ }^{8}$ The computational resources at Stony Brook University are provided in part by the National Science Foundation under CHE-1609669, the Department of Energy under DE-SC0016017 and the Stony Brook University Department of Chemistry through the course fees budget.

Ring separation energies for 3-N spirocyclopropenes under isodesmic conditon

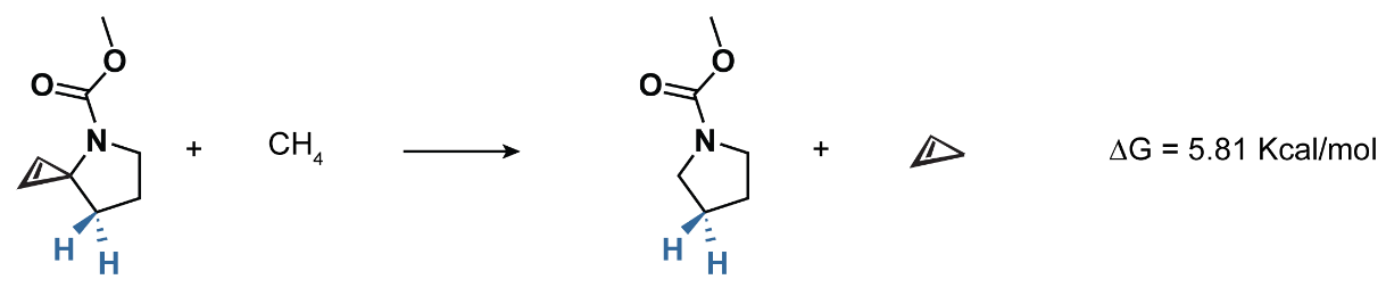

GO-HH-CP

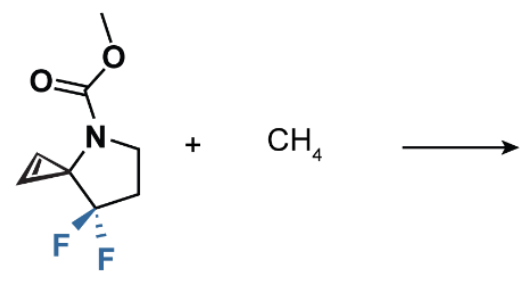

G1-FF-CP

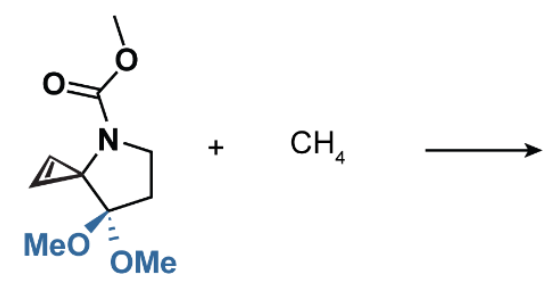

G2-ketal-CP<smiles>COC(=O)N1CCC(=O)C23CCC12C3</smiles>

G2-ketone-CP

$$
\text { G0-HH }
$$
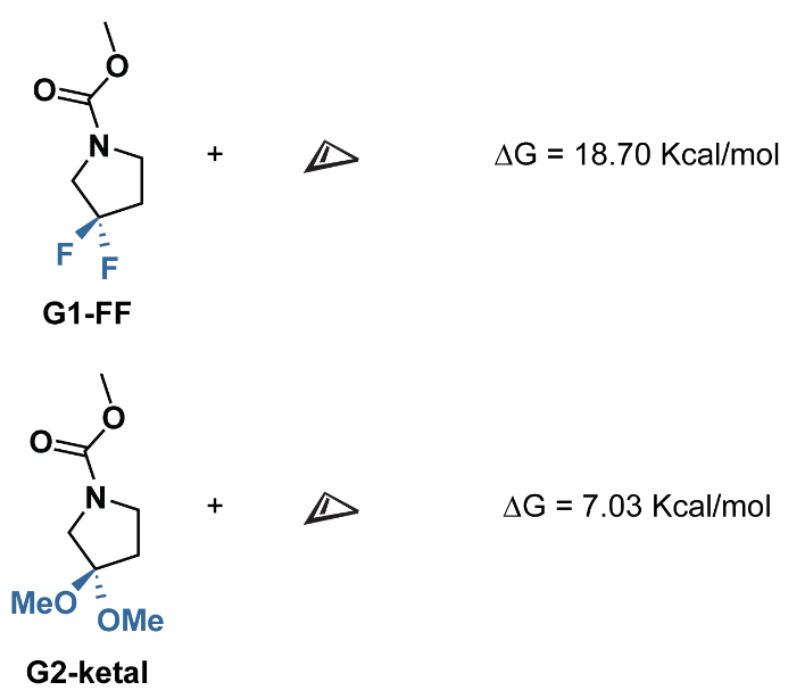<smiles>COC(=O)N1CCC(=O)C1</smiles>

G2-ketone 
$\mathbf{C H}_{4}$, RB3LYP energy: -40.53489125 Hartree

C 0.000000000 .000000000 .00000000

H $\quad 0.62925300 \quad 0.629253000 .62925300$

H $\quad-0.62925300-0.629253000 .62925300$

H $\quad-0.629253000 .62925300-0.62925300$

H $\quad 0.62925300-0.62925300-0.62925300$

Cyclopropene, RB3LYP energy: -116.6565648 Hartree

C 0.000000000 .000000000 .00000000

C $-1.36504300-0.64338500 \quad 0.00000800$

C $-1.36485800 \quad 0.64367000 \quad 0.00000100$

H $-1.907928001 .57247000-0.00001500$

H $-1.90828800-1.57207600-0.00001000$

H $\quad 0.59611500 \quad 0.000013000 .91213500$

H $\quad 0.59610100-0.00002200-0.91214300$

G0-HH-CP, RB3LYP energy: - 516.749825088 Hartree

C 0.000000000 .000000000 .00000000

N $-0.870489001 .18562100-0.01095200$

C $-0.092872002 .42580300-0.20962100$

C $1.216198001 .92205600-0.80644900$

C $1.420343000 .57589300-0.10208500$

H 1.834424000 .739491000 .89609500

H $\quad 2.09258200-0.09739500-0.63424800$

H $2.029727002 .62870700-0.64428700$

H $\quad 1.101650001 .77469400-1.88607100$

C -0.180320003 .577367000 .73875000$

C $-0.703246003 .75277100-0.43353900$

H $\quad-1.265235004 .37470200-1.10962600$

H $\quad 0.001022003 .952255001 .73248000$

C $-2.21133500 \quad 0.98733000-0.08588100$

O $-2.909052002 .14164400-0.26354900$

C $-4.332891001 .97799100-0.32080200$

H $\quad-4.732859002 .98144600-0.45038800$

H $\quad-4.616032001 .34313300-1.16016500$

H $\quad-4.707846001 .535294000 .60169100$

O $-2.74279600-0.10450800-0.00376700$

H $\quad-0.15701300-0.588641000 .90486900$

H $\quad-0.24333700-0.64134700-0.85126300$ 
G0-HH, RB3LYP energy: -440.618893182

C 0.000000000 .000000000 .00000000

N $1.00424800-1.067902000 .04145200$

C $0.41480100-2.410168000 .12070700$

C $-1.06890600-2.15325900-0.17029200$

C $-1.29864600-0.72977400 \quad 0.36032200$

H $-1.42645500-0.750115001 .44599900$

H $-2.17724900-0.24836900-0.06982800$

H $\quad-1.71607700-2.89662600 \quad 0.29621500$

H $-1.24701200-2.18455100-1.24854300$

H $\quad 0.88048300-3.08380400-0.59856200$

H $\quad 0.56013700-2.836457001 .11900700$

C $2.32531100-0.78171800 \quad 0.04221000$

O $3.07681000-1.91649000 \quad 0.12436000$

C $4.49433100-1.698451000 .12218300$

H $4.93897300-2.688890000 .18944800$

H $\quad 4.80658400-1.20187800-0.79635700$

H $\quad 4.79170400-1.08844100 \quad 0.97492500$

O $\quad 2.79759800 \quad 0.33777000-0.02084400$

H $\quad 0.26102600 \quad 0.796197000 .69709700$

H $\quad-0.04786300 \quad 0.44077800-1.00140200$

G1-FF-CP, RB3LYP energy: -715.304128840 Hartree

C 0.000000000 .000000000 .00000000

N $-0.71667200-1.287201000 .02640800$

C $\quad 0.20133300-2.42981900 \quad 0.13916300$

C $1.52016700-1.767966000 .51807600$

C $1.47932600-0.39041600-0.10575800$

H $\quad 1.79109100-0.48385400-1.14719700$

H $2.14469800 \quad 0.304993000 .40274000$

F $2.59406400-2.507548000 .11620200$

F $1.62024300-1.667071001 .89267700$

C $\quad 0.15759200-3.64402900-0.71801800$

C $-0.16711700-3.80343200 \quad 0.52427000$

H $\quad-0.52602800-4.432641001 .31976600$

H $\quad 0.26311000-4.04552600-1.71121400$

C $-2.06011200-1.24972700 \quad 0.25094400$

O $-2.59649200-2.48155700 \quad 0.43237500$

C $-4.01554100-2.49202800 \quad 0.65631200$

H $\quad-4.27912700-3.54045600 \quad 0.77513600$

H $\quad-4.26727300-1.929794001 .55493900$ 
H $\quad-4.54103500-2.06035500-0.19482500$

O $-2.70833700-0.22250000 \quad 0.27495300$

H $\quad-0.334659000 .60965100-0.83873400$

H $\quad-0.20562700 \quad 0.55643900 \quad 0.91656500$

G1-FF, RB3LYP energy: -639.152648963 Hartree

C 0.000000000 .000000000 .00000000

N $\quad-0.83962800-1.19110300 \quad 0.25494000$

C $-0.03062100-2.37725900 \quad 0.55740900$

C $1.39179100-1.826047000 .61752600$

C $1.38966500-0.58558400-0.25403800$

H $\quad 1.50717900-0.89730900-1.29345800$

H $2.20197000 \quad 0.089214000 .00981800$

F $\quad 2.31149000-2.76062400 \quad 0.23037400$

F $\quad 1.70750100-1.490659001 .91442900$

H $\quad-0.30846800-2.834771001 .50668500$

H $\quad-0.08129900-3.12873900-0.23392800$

C $-2.11015600-0.97733100 \quad 0.72387000$

O $-2.83857100-2.093011001 .02385500$

C $-2.90374200-3.180464000 .08979100$

H $\quad-3.93951500-3.51606600 \quad 0.08190500$

H $-2.62139100-2.85736200-0.91320200$

H $\quad-2.26355800-4.00567500 \quad 0.40668500$

$\begin{array}{llll}\text { O } & -2.57526100 & 0.12466100 & 0.88796400\end{array}$

H $\quad-0.38839400 \quad 0.56370100-0.84698300$

H $\quad-0.01223600 \quad 0.657108000 .87204200$

G2-ketone-CP, RB3LYP energy: -590.789876331 Hartree

C 0.000000000 .000000000 .00000000

N $\quad 0.755292001 .25065500-0.15506400$

C $-0.158782002 .38713900-0.27397600$

C $-1.475469001 .77854100-0.70187800$

C $-1.31740500 \quad 0.26706500-0.73870700$

H $-1.24865700-0.03598800-1.78835900$

H $\quad-2.18620700-0.22699200-0.30515300$

O $-2.475502002 .40404300-0.94899300$

C $0.224148003 .78511800-0.59355000$

C $-0.141415003 .59084500 \quad 0.62469000$

H $\quad-0.310053003 .945903001 .62627600$

H $\quad 0.594450004 .42753000-1.37258900$

C $2.102485001 .20279700-0.34390900$

O $2.76987200 \quad 0.19025700-0.26656000$ 
O $2.624260002 .42263700-0.63111900$

C $4.048126002 .43850400-0.81999800$

H $4.331349001 .80955900-1.66339200$

H $4.299732003 .47796900-1.01779600$

H 4.557974002 .086144000 .07596300

H $\quad 0.57881600-0.82281700-0.41014400$

H $\quad-0.17791700-0.206846001 .06053100$

G2-ketone, RB3LYP energy: -514.65483798 Hartree

C 0.000000000 .000000000 .00000000

N $\quad 0.83747300-1.19828200 \quad 0.14935500$

C $\quad 0.08305500-2.437168000 .04829100$

C $-1.37028400-1.98968300 \quad 0.19207300$

C $-1.39431700-0.48104200 \quad 0.40659700$

H $-1.58072100-0.307651001 .47143800$

H $-2.21066000-0.02385800-0.15101800$

O $-2.32216600-2.72202600 \quad 0.14055700$

H $\quad 0.21252900-2.94549300-0.91425900$

H $\quad 0.34172700-3.14857800 \quad 0.83496200$

C $2.19169100-1.09697000 \quad 0.15717400$

O $2.77224300-2.32432000 \quad 0.19837100$

C $\quad 4.20802900-2.31162900 \quad 0.24604200$

H $\quad 4.50445000-3.35758500 \quad 0.26325800$

H $\quad 4.61575000-1.81219000-0.63214500$

H $4.55667900-1.800567001 .14299400$

O $2.80664200-0.05021800 \quad 0.14053000$

H $\quad 0.39086400 \quad 0.798921000 .62627800$

H $\quad 0.01311800 \quad 0.35421300-1.03665100$

G2-ketal-CP, RB3LYP energy: -745.869293328 Hartree

C 0.000000000 .000000000 .00000000

$\mathrm{N} \quad-0.37818100 \quad 1.42253000-0.02582800$

C 0.801374002 .289559000 .03340200

C $1.929834001 .37852100-0.47850800$

C 1.531872000 .021420000 .11601600

H $\quad 1.84655200-0.003775001 .16082400$

H $\quad 1.98934000-0.81195200-0.41483700$

O $3.151084001 .90508800-0.03407300$

C $4.298298001 .10343700-0.29403300$

H $\quad 5.160026001 .70068600-0.00002100$

H $4.28594300 \quad 0.18251900 \quad 0.29807900$

H $\quad 4.37575500 \quad 0.84785900-1.35338000$ 
O $\quad 1.916234001 .18884300-1.88531900$

C $2.001310002 .36590900-2.68593900$

H $2.256624002 .03164300-3.69103100$

H $1.045393002 .89440200-2.71850000$

H $2.779857003 .04109400-2.32185800$

C $0.730017003 .76203900-0.02776600$

C 1.006434003 .270366001 .13515400

H 1.187808003 .411065002 .18627200

H $\quad 0.511042004 .61278300-0.64760000$

C $-1.593704001 .86460300-0.43525800$

O $-1.883603003 .01370400-0.71054700$

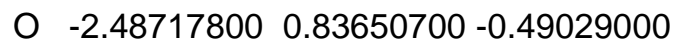

C $-3.806980001 .20700700-0.91121700$

H $\quad-4.37981500 \quad 0.28235400-0.91173200$

H $\quad-4.244169001 .92584300-0.21841600$

H $\quad-3.785888001 .64298100-1.90985800$

H $\quad-0.47213000-0.518035000 .83653300$

H $\quad-0.31919800-0.48669000-0.92188900$

G2-ketone, RB3LYP energy: -669.736423078 Hartree

C -3.199080000 .678636001 .93460300$

H $\quad-4.031261001 .024314001 .31689300$

H $\quad-3.03140900-0.387103001 .75204000$

H $\quad-3.44711700 \quad 0.816651002 .98608900$

O $-2.690202002 .41451100-0.32028900$

C -2.993921003 .695959000 .22597300$

H $\quad-3.842504004 .07439000-0.34132200$

H $\quad-3.261275003 .628635001 .28295400$

H $-2.154016004 .38890500 \quad 0.11187300$

H $\quad-0.178334002 .951043001 .31338800$

H $\quad-0.215469003 .07786700-0.45955700$

C 1.969024001 .368570000 .51651000

O $2.346892002 .65010500 \quad 0.78286900$

C 3.748036002 .821950001 .03787500

H 3.877638003 .883829001 .23445200

H 4.057078002 .233592001 .90156300

H 4.336694002 .519724000 .17193100

$\begin{array}{llll}\text { O } & 2.73883300 & 0.42775500 & 0.48293900\end{array}$

H $\quad 0.55772300-0.54075400-0.76395500$

H $\quad-0.02570000-0.622852000 .89910100$ 


\section{References}

1. Clark, W., Still, W. C., Kahn, M. \& Mitra, A. Rapid Chromatographic Technique for Preparative Separations with Moderate Resolution. J. Org. Chem. 43, 2923-2925 (1978).

2. Kumar, P., Jiang, T., Li, S., Zainul, O. \& Laughlin, S. T. Caged cyclopropenes for controlling bioorthogonal reactivity. Org. Biomol. Chem. 16, 4081-4085 (2018).

3. Moreau, R. J. \& Sorensen, E. J. Classical carbonyl reactivity enables a short synthesis of the core structure of acutumine. Tetrahedron 63, 6446-6453 (2007).

4. Kumar, P., Zainul, O. \& Laughlin, S. T. Inexpensive multigram-scale synthesis of cyclic enamines and 3N spirocyclopropyl systems. Org. Biomol. Chem. 16, 652-656 (2018).

5. $\quad$ Kim, R., Sherrill, W. M. \& Rubin, M. Ring-retentive deprotonation of cyclopropene-3-carboxamides. Tetrahedron 66, 4947-4953 (2010).

6. Sun, J. et al. Highly Efficient Chemoselective Deprotection of O,O -Acetals and O,O -Ketals Catalyzed by Molecular lodine in Acetone. J. Org. Chem. 69, 8932-8934 (2004).

7. Kao, J. \& Radom, L. An ab initio molecular orbital study of structures and energies of spiro compounds: spiropentane, spiropentene, spiropentadiene, spiro[2.4]hepta-4,6-diene, spiro[2.4]heptatriene, and spiro[4.4]nonatetraene. J. Am. Chem. Soc. 100, 760-767 (1978).

8. Gaussian 16, Revision A.03, M. J. Frisch, G. W. Trucks, H. B. Schlegel, G. E. Scuseria, M. A. Robb, J. R. Cheeseman, G. Scalmani, V. Barone, G. A. Petersson, H. Nakatsuji, X. Li, M. Caricato, A. V. Marenich, J. Bloino, B. G. Janesko, R. Gomperts, B. Mennucci, H. P. Hratchian, J. V. Ortiz, A. F. Izmaylov, J. L. Sonnenberg, D. Williams-Young, F. Ding, F. Lipparini, F. Egidi, J. Goings, B. Peng, A. Petrone, T. Henderson, D. Ranasinghe, V. G. Zakrzewski, J. Gao, N. Rega, G. Zheng, W. Liang, M. Hada, M. Ehara, K. Toyota, R. Fukuda, J. Hasegawa, M. Ishida, T. Nakajima, Y. Honda, O. Kitao, H. Nakai, T. Vreven, K. Throssell, J. A. Montgomery, Jr., J. E. Peralta, F. Ogliaro, M. J. Bearpark, J. J. Heyd, E. N. Brothers, K. N. Kudin, V. N. Staroverov, T. A. Keith, R. Kobayashi, J. Normand, K. Raghavachari, A. P. Rendell, J. C. Burant, S. S. Iyengar, J. Tomasi, M. Cossi, J. M. Millam, M. Klene, C. Adamo, R. Cammi, J. W. Ochterski, R. L. Martin, K. Morokuma, O. Farkas, J. B. Foresman, and D. J. Fox, Gaussian, Inc., Wallingford CT, 2016. 